\title{
Halide-Accelerated Acyl Fluoride Formation Using Sulfuryl Fluoride
}

\author{
Paul J. Foth, Thomas C. Malig, Hao Yu, Trevor G. Bolduc, Jason E. Hein*, \\ Glenn M. Sammis*
}

Table of contents

General methods and instrumentation

S2

Optimization of the formation of acyl fluorides from carboxylic acids using S3 $\mathrm{SO}_{2} \mathrm{~F}_{2}$

Investigation into additives for the conversion of carboxylic acids to acyl

S6 fluorides

Representative example for the ${ }^{19} \mathrm{~F}$ NMR yield determination

S7

Representative procedure for kinetic experiments monitored by ReactIR S8

COPASI Model

S10

Investigations into the formation of mixed sulfuryl halide

S12

Carboxylic acid kinetic experiments monitored by ${ }^{19} \mathrm{~F}$ NMR spectroscopy

S14

Reaction of carboxylic acid with sulfuryl chloride and tetramethylammonium S17 fluoride (TMAF) monitored by ${ }^{19} \mathrm{~F}$ NMR spectroscopy

General procedure for the conversion of carboxylic acids to acyl fluorides using $\mathrm{SO}_{2} \mathrm{~F}_{2}$

General procedure for the acyl fluoride yields determined by ${ }^{19} \mathrm{~F}$ NMR S19 spectroscopy

General procedure for the synthesis of carboxylic acid derivatives by one-pot $\mathbf{S 2 0}$ sequential protocol

Procedure for the single-addition reactions $\quad$ S35

${ }^{1} \mathrm{H}$ and ${ }^{13} \mathrm{C}$ NMR Spectra $\quad$ S36 


\section{General methods and instrumentation}

All reactions were performed in either 1 dram vials or $20 \mathrm{~mL}$ scintillation vials and were heated using an aluminum heating block unless otherwise noted. All chemicals were purchased from commercial sources and used as received unless otherwise noted. 1,1'-Sulfonyldiimidazole (SDI) was prepared and used to generate sulfuryl fluoride $\left(\mathrm{SO}_{2} \mathrm{~F}_{2}\right)$ following a modified procedure from Org. Lett. 2017, 19, 5244-5247. $\mathrm{SO}_{2} \mathrm{~F}_{2}$ is a toxic gas and all work should be done in a wellventilated area or a fumehood. Screw caps and PTFE/Silicon septa were purchased from Chemglass Life Sciences LLC. BD Intramedic ${ }^{\text {TM }}$ (I.D. $1.57 \mathrm{~mm}$, O.D. 2.08mm) polyethylene tubing was used for the reactions. $N, N$-diisopropylethylamine is abbreviated as DIPEA.

For ReactIR and ${ }^{19} \mathrm{~F}$ NMR kinetic studies, tetrabutylammonium chloride (TBAC), tetrabutylammonium bromide (TBAB), and tetrabutylammonium iodide (TBAI), were each recrystallized using acetone and diethyl ether, according to a literature procedure in J. Am. Chem. Soc. 1986, 108, 1962-1969. Upon crystallizing, each salt was suction filtered and left to dry in vacuo for a minimum of $48 \mathrm{hr}$. During drying, TBAC was maintained at room temperature, TBAB at $60^{\circ} \mathrm{C}$, and TBAI at $90^{\circ} \mathrm{C}$. Tetramethylammonium fluoride (TMAF) was used from commercial sources. For the substrate scope syntheses, the TBAB used was purchased from TCI Chemicals.

$N$-N-Dimethylformamide (DMF) was dried over $4 \AA$ molecular sieves. Acetonitrile (ACN), dichloromethane (DCM), tetrahydrofuran (THF), benzene, and hexanes were obtained from a solvent purification system (SPS).

Flash column chromatography was performed using Silicycle F60 silica: 230-400 mesh (40-63 $\mu \mathrm{m})$ silica. The silica gel used for acyl fluoride isolation was supplied by Sigma-Aldrich (Davisil Grade 633, 60A, 200-425 mesh). TLC's were run on Merck Kieselgel $60 \mathrm{~F}_{254}$ aluminum or glass backed plates and visualized by UV fluorescence $(254 \mathrm{~nm})$ then one of the following: $\mathrm{KMnO}_{4}$, bromocresol green.

Infrared (IR) spectra were obtained using a Thermo Nicolet 4700 FT-IR spectrometer or a Perkin Elmer Frontier FT-IR. The spectra are reported in $\mathrm{cm}^{-1}$. Melting points are uncorrected and determined by the open capillary method using a Mel-Temp II apparatus. High resolution mass spectra (HRMS) were recorded on a Waters or Micromass LCT spectrometer or a JEOL AccuTOF-GC spectrometer.

Proton, carbon and fluorine nuclear magnetic resonance $\left({ }^{1} \mathrm{H},{ }^{13} \mathrm{C}\right.$ and $\left.{ }^{19} \mathrm{~F} N M R\right)$ spectra were recorded using a Bruker AV-300 or Bruker AV-400 spectrometer. Chemical shifts $(\delta)$ are reported in parts per million (ppm) and are referenced to the centerline of $\mathrm{CDCl}_{3}\left(7.26 \mathrm{ppm}{ }^{1} \mathrm{H} \mathrm{NMR} ; 77.16\right.$ ppm ${ }^{13} \mathrm{C}$ NMR). ${ }^{19} \mathrm{~F}$ NMR chemical shifts were referenced to $\mathrm{CFCl}_{3}(0.00 \mathrm{ppm})$. Coupling constants $(\mathcal{J})$ are reported in $\mathrm{Hz}$ to the nearest $0.1 \mathrm{~Hz}$. Peak multiplicity is indicated as follows: $\mathrm{s}$ (singlet), $\mathrm{d}$ (doublet), t (triplet), q (quartet), br s (broad singlet), m (multiplet), dd (doublet of doublets), $d t$ (doublet of triplets), td (triplet of doublets), ddd (doublet of doublets of doublets), tdd (triplet of doublets of doublets). Selection of peaks was done based on the chemical shifts, multiplicities and integrals of the peaks.

NMR yields were determined by ${ }^{19} \mathrm{~F}$ NMR spectroscopy using a relaxation delay (or recycle delay) of 40 seconds to ensure complete relaxation of all fluorine nuclei and the center of the spectral window (o1p) equidistant to the peaks of interest. $\alpha, \alpha, \alpha-$ Trifluorotoluene ( $\left.\mathrm{PhCF}_{3}, \delta-63.14 \mathrm{ppm}\right)$ was used as an internal standard to quantify the product, unless otherwise specified. Multiple quantitative ${ }^{19} \mathrm{~F}$ NMR yields were tested using $p$-toluenesulfonyl fluoride $(\delta+65.7 \mathrm{ppm})$ and the yields were in agreement. 
ReactIR data was collected using a Mettler-Toledo ReactIR 15 with an MCT detector, and a DSTDiComp probe with a diamond ATR crystal. A spectral window of 3000 to $650 \mathrm{~cm}^{-1}$ was used for all experiments.

\section{Optimization of the formation of acyl fluorides from carboxylic acids using $\mathrm{SO}_{2} \mathrm{~F}_{2}$}

Table S1 - Optimization of reaction solvent for the conversion of carboxylic acids to acyl fluorides using $\mathrm{SO}_{2} \mathrm{~F}_{2}$.

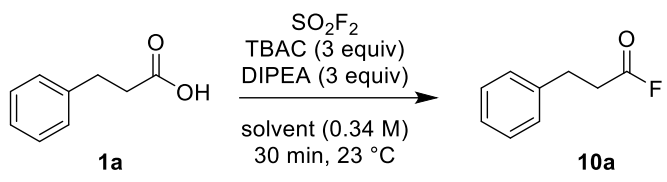

\begin{tabular}{ccc}
\hline entry & solvent & $\begin{array}{c}{ }^{19} \mathbf{F ~ N M R} \text { yield } \\
(\%)\end{array}$ \\
\hline 1 & $\mathrm{ACN}$ & 74 \\
\hline 2 & $\mathrm{THF}$ & 11 \\
\hline 3 & $\mathrm{DCM}$ & 19 \\
\hline 4 & $\mathrm{DMF}$ & 33 \\
\hline 5 & $\mathrm{Et}_{2} \mathrm{O}$ & 4 \\
\hline 6 & $\mathrm{DMSO}$ & 4 \\
\hline
\end{tabular}

Reaction conditions: The reactions were set up following the general procedure for conversion of carboxylic acids to acyl fluorides using $0.3 \mathrm{mmol}$ of carboxylic acid $\mathbf{1 a} . \mathrm{SO}_{2} \mathrm{~F}_{2}$ ( $\sim 5.8$ equiv), generated from SDI, $\mathrm{KF}$, and TFA, was bubbled through the mixture containing carboxylic acid 1a, DIPEA (3 equiv), TBAC (3.1 equiv), and $A C N(0.34 \mathrm{M})$. The mixture was then stirred for $30 \mathrm{~min}$, unless otherwise stated. Internal standard $\left(\mathrm{PhCF}_{3}\right)$ was added and the yields were determined by quantitative ${ }^{19} \mathrm{~F}$ NMR spectroscopy.

Table S2 - Optimization of the additive for the conversion of carboxylic acids to acyl fluorides using $\mathrm{SO}_{2} \mathrm{~F}_{2}$.

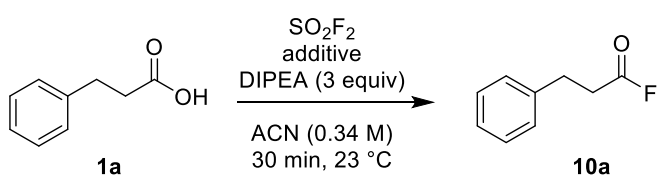

\begin{tabular}{ccc}
\hline entry & additive & $\begin{array}{c}\mathbf{1 9}^{\mathbf{F}} \mathbf{N M R} \text { yield } \\
\mathbf{( \% )}\end{array}$ \\
\hline 1 & TBAC (3 equiv) & 74 \\
\hline 2 & TBAB (3 equiv) & 76 \\
\hline 3 & TBAI (3 equiv) & 54 \\
\hline 4 & TBAB (0.5 equiv) & 44 \\
\hline 5 & TBAB (1 equiv) & 64 \\
\hline 6 & TBAB (2 equiv) & 72 \\
\hline
\end{tabular}

Reaction conditions: The reactions were set up following the general procedure for conversion of carboxylic acids to acyl fluorides using $0.3 \mathrm{mmol}$ of carboxylic acid $1 \mathrm{a} . \mathrm{SO}_{2} \mathrm{~F}_{2}$ ( 5.8 equiv), generated from SDI, KF, and TFA, was bubbled through the mixture containing carboxylic acid 1a, DIPEA (3 equiv), additive, and $\mathrm{ACN}(0.34 \mathrm{M})$. The mixture was then stirred for $30 \mathrm{~min}$, unless otherwise stated. Internal standard $\left(\mathrm{PhCF}_{3}\right)$ was added and the yields were determined by quantitative ${ }^{19} \mathrm{~F}$ NMR spectroscopy. 


\section{Comment on the amount of TBAB:}

The optimization studies indicated that the reaction was most efficient when 3 equivalents of TBAB were utilized. Due to the desire to minimize the amount of reagents, 1 equivalent TBAB was selected for further optimization.

Table S3 - Optimization of the base for the conversion of carboxylic acids to acyl fluorides using $\mathrm{SO}_{2} \mathrm{~F}_{2}$.

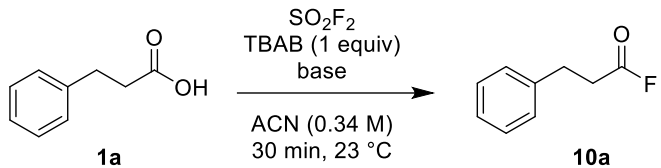

\begin{tabular}{ccc}
\hline entry & base & $\begin{array}{c}{ }^{19} \mathbf{F} \text { NMR yield } \\
(\%)\end{array}$ \\
\hline 1 & $\mathrm{DIPEA}^{(3}$ equiv) & 64 \\
\hline 2 & $\mathrm{Et}_{3} \mathrm{~N}$ (3 equiv) & 61 \\
\hline 3 & $\mathrm{DBU}^{3}$ (3 equiv) & 10 \\
\hline 4 & $\mathrm{~K}_{2} \mathrm{CO}_{3}$ (3 equiv) & 17 \\
\hline 5 & $\mathrm{NaHCO}_{3}$ (3 equiv) & 0 \\
\hline 6 & $\mathrm{NaOH}$ (3 equiv) & 0 \\
\hline 7 & $t \mathrm{BuOK}$ (3 equiv) & 3 \\
\hline 8 & $\mathrm{DIPEA}(2$ equiv) & 61 \\
\hline 9 & $\mathrm{DIPEA}(1$ equiv) & 41 \\
\hline 10 & None & 0
\end{tabular}

Reaction conditions: The reactions were set up following the general procedure for conversion of carboxylic acids to acyl fluorides using $0.3 \mathrm{mmol}$ of carboxylic acid 1a. $\mathrm{SO}_{2} \mathrm{~F}_{2}$ ( 5.8 equiv), generated from SDI, $\mathrm{KF}$, and TFA, was bubbled through the mixture containing carboxylic acid 1a, base, TBAB (1 equiv), and ACN $(0.34 \mathrm{M})$. The mixture was then stirred for $30 \mathrm{~min}$, unless otherwise stated. Internal standard $\left(\mathrm{PhCF}_{3}\right)$ was added and the yields were determined by quantitative ${ }^{19} \mathrm{~F}$ NMR spectroscopy.

\section{Comment on the amount of base:}

Two equivalents of DIPEA was selected for continued reaction optimization as the ${ }^{19} \mathrm{~F}$ NMR yield was very similar to the reactions using three equivalents of DIPEA. Three equivalents of DIPEA was utilized in the investigation of other additives (Table S6), as well as for the larger scale (1 mmol) one-pot sequential reactions in the event of increased trifluoroacetic acid (TFA) transfer when generating $\mathrm{SO}_{2} \mathrm{~F}_{2}$. 
Table S4 - Optimization of the reaction concentration for the conversion of carboxylic acids to acyl fluorides using $\mathrm{SO}_{2} \mathrm{~F}_{2}$.

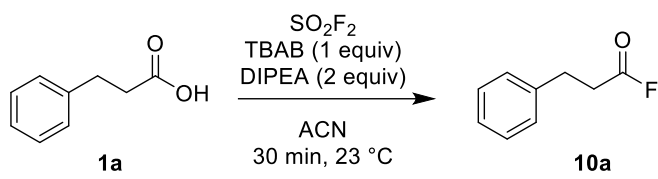

\begin{tabular}{ccc}
\hline entry & conc (M) & $\begin{array}{c}{ }^{19} \mathbf{F} \text { NMR yield } \\
(\%)\end{array}$ \\
\hline 1 & 1.0 & 39 \\
\hline 2 & 0.5 & 50 \\
\hline 3 & 0.34 & 60 \\
\hline 4 & 0.1 & 68 \\
\hline
\end{tabular}

Reaction conditions: The reactions were set up following the general procedure for conversion of carboxylic acids to acyl fluorides using $0.3 \mathrm{mmol}$ of carboxylic acid $1 \mathrm{a}$. $\mathrm{SO}_{2} \mathrm{~F}_{2}$ ( 5.8 equiv), generated from SDI, KF, and TFA, was bubbled through the mixture containing carboxylic acid 1a, DIPEA (2 equiv), TBAB (1 equiv), and $A C N$. The mixture was then stirred for 30 min, unless otherwise stated. Internal standard $\left(\mathrm{PhCF}_{3}\right)$ was added and the yields were determined by quantitative ${ }^{19} \mathrm{~F}$ NMR spectroscopy.

Table S5 - Optimization of the reaction temperature for the conversion of carboxylic acids to acyl fluorides using $\mathrm{SO}_{2} \mathrm{~F}_{2}$.

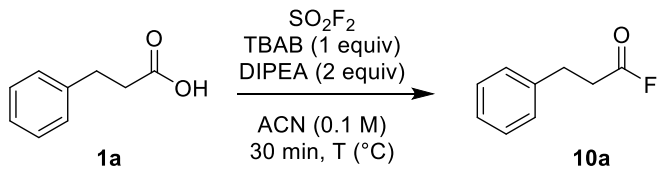

\begin{tabular}{ccc}
\hline entry & $\mathbf{T}\left({ }^{\circ} \mathbf{C}\right)$ & ${ }^{19} \mathbf{F}$ NMR yield $(\%)$ \\
\hline 1 & 0 & 49 \\
\hline 2 & 23 & 68 \\
\hline 3 & 40 & 76 \\
& & $88(1 \mathrm{~h})$ \\
\hline 4 & 60 & 72
\end{tabular}

Reaction conditions: The reactions were set up following the general procedure for conversion of carboxylic acids to acyl fluorides using $0.3 \mathrm{mmol}$ of carboxylic acid 1a. $\mathrm{SO}_{2} \mathrm{~F}_{2}(\sim 5.8$ equiv), generated from SDI, KF, and TFA, was bubbled through the mixture containing carboxylic acid 1a, DIPEA (2 equiv), TBAB (1 equiv), and $A C N(0.1 \mathrm{M})$. The mixture was then stirred for $30 \mathrm{~min}$, unless otherwise stated. Internal standard $\left(\mathrm{PhCF}_{3}\right)$ was added and the yields were determined by quantitative ${ }^{19} \mathrm{~F}$ NMR spectroscopy. 


\section{Investigation into additives for the conversion of carboxylic acids to acyl fluorides}

Table S6 - The effect of additives on the conversion of carboxylic acids to acyl fluorides

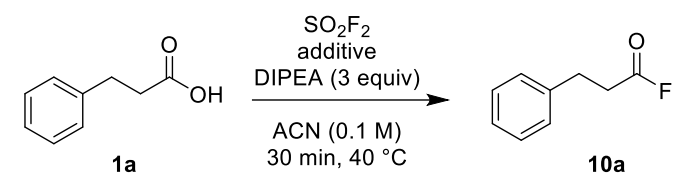

\begin{tabular}{ccc}
\hline entry & additive & $\begin{array}{c}\mathbf{1 9}^{\mathbf{9}} \mathbf{N M R} \text { yield } \\
(\%)\end{array}$ \\
\hline $\mathbf{1}$ & DMAP & 61 \\
\hline $\mathbf{2}$ & Pyridine & 81 \\
\hline $\mathbf{3}$ & Imidazole & 42 \\
\hline $\mathbf{4}$ & DABCO & 74 \\
\hline $\mathbf{5}$ & TBAC & 91 \\
\hline $\mathbf{6}$ & TBAB & 90 \\
\hline $\mathbf{7}$ & none & 67 \\
\hline
\end{tabular}

Reaction conditions: The reactions were set up following the general procedure for conversion of carboxylic acids to acyl fluorides using $0.3 \mathrm{mmol}$ of carboxylic acid $1 \mathrm{a} . \mathrm{SO}_{2} \mathrm{~F}_{2}$ ( 5.8 equiv), generated from SDI, KF, and TFA, was bubbled through the mixture containing carboxylic acid 1a, DIPEA (3 equiv), additive (1 equiv), and $A C N(0.1 \mathrm{M})$. The mixture was then stirred for $30 \mathrm{~min}$, unless otherwise stated. Internal standard $\left(\mathrm{PhCF}_{3}\right)$ was added and the yields were determined by quantitative ${ }^{19} \mathrm{~F}$ NMR spectroscopy. 


\section{Representative example for the ${ }^{19} \mathrm{~F}$ NMR yield determination}
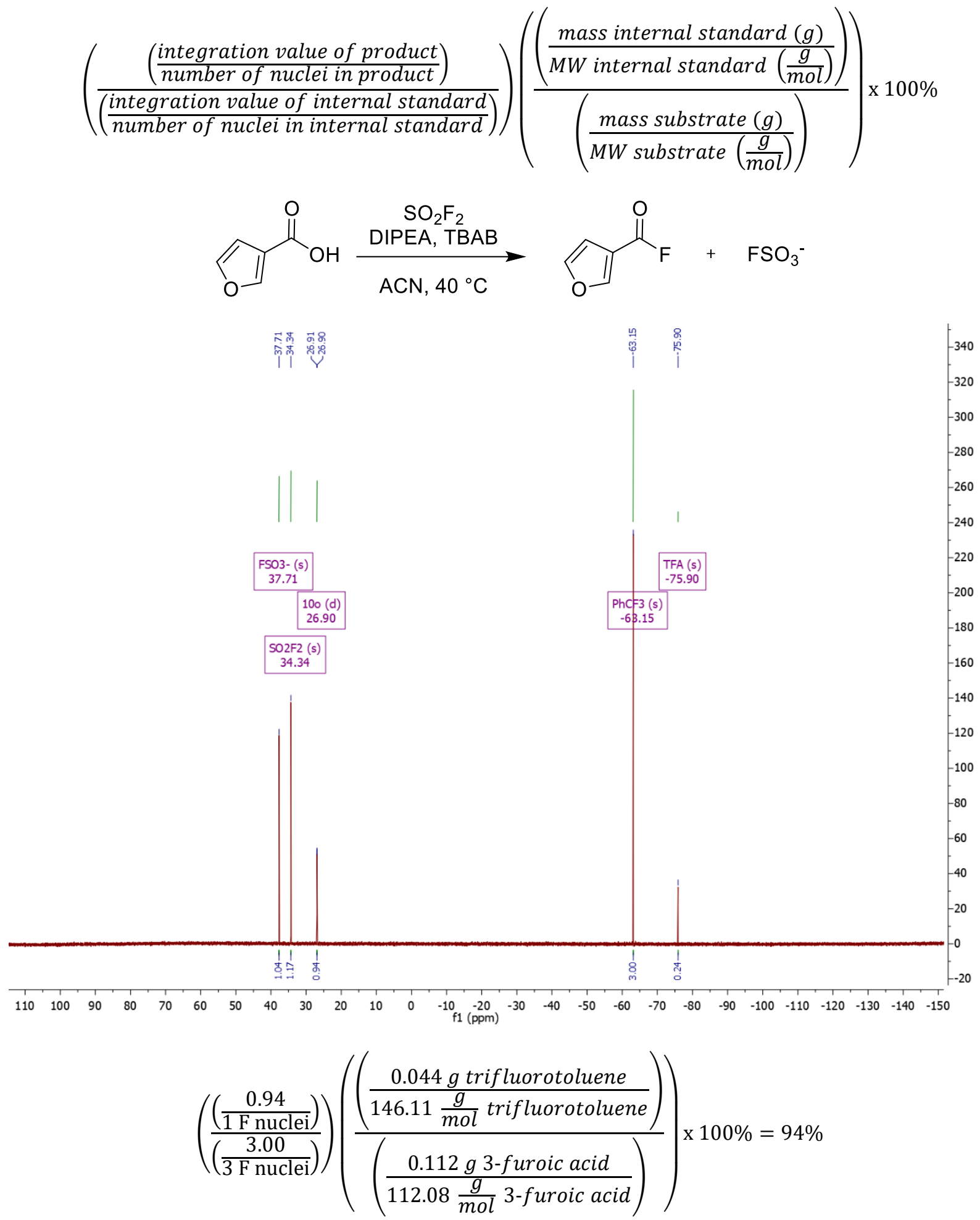


\section{Representative procedure for kinetic experiments monitored by ReactlR}

Scheme S1 - Reaction of carboxylic acid with DIPEA, additive, and $\mathrm{SO}_{2} \mathrm{~F}_{2}$ monitored by ReactIR.

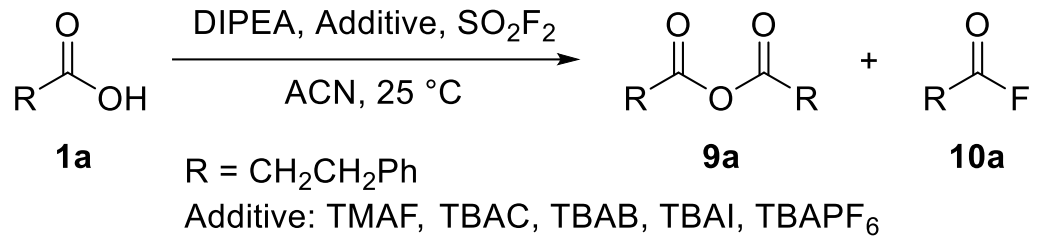

To a $20 \mathrm{~mL}$ vial fitted with a screw cap and pierceable Teflon septum (vial 1: generator vial) was added anhydrous potassium fluoride (453 mg, 15.6 equiv, $7.80 \mathrm{mmol}$ ), SDI (287 mg, 2.90 equiv, $1.45 \mathrm{mmol}$ ), and a stir bar. The generator vial was placed in an Easymax 102 where the temperature $(\mathrm{Tj})$ was set to $20^{\circ} \mathrm{C}$ and the stir rate was set to $50 \mathrm{rpm}$. To a separate $20 \mathrm{~mL}$ vial fitted with a screw cap and pierceable teflon septum (vial 2: receiver vial) was added ACN (5.0 $\mathrm{mL})$, 3-phenylpropionic acid $(75.1 \mathrm{mg}, 0.500 \mathrm{mmol})$, additive $(0.500 \mathrm{mmol}$ for TMAF, TBAC, TBAB, TBAI, TBAPF 6 ), and DIPEA (200 mg, $1.6 \mathrm{mmol})$. The receiver vial was placed in an Easymax 102 where the temperature (Tj) was set to $25^{\circ} \mathrm{C}$ and the stir rate was set to $500 \mathrm{rpm}$. $A$ vent needle was connected to the receiver vial. The generator and receiver vials were connected via a PEEK capillary. The ReactIR probe was blanked in air, then acetonitrile, and was inserted into the receiver vial through the septum. Data acquisition using iC IR (React IR software) was then initiated. Trifluoroacetic acid $(2.48 \mathrm{~g}, 1.68 \mathrm{~mL}, 21.8 \mathrm{mmol})$ was dosed into the generator vial at a rate of $0.1 \mathrm{~mL} / \mathrm{min}$ to initiate generation of $\mathrm{SO}_{2} \mathrm{~F}_{2}$. ReactIR data analysis was performed on the double derivative of the IR spectra to allow for better peak deconvolution. Anhydride 9a was trended via the peak at $1820 \mathrm{~cm}^{-1}$, acyl fluoride $10 \mathrm{a}$ was trended via the peak at $1846 \mathrm{~cm}^{-1}$.
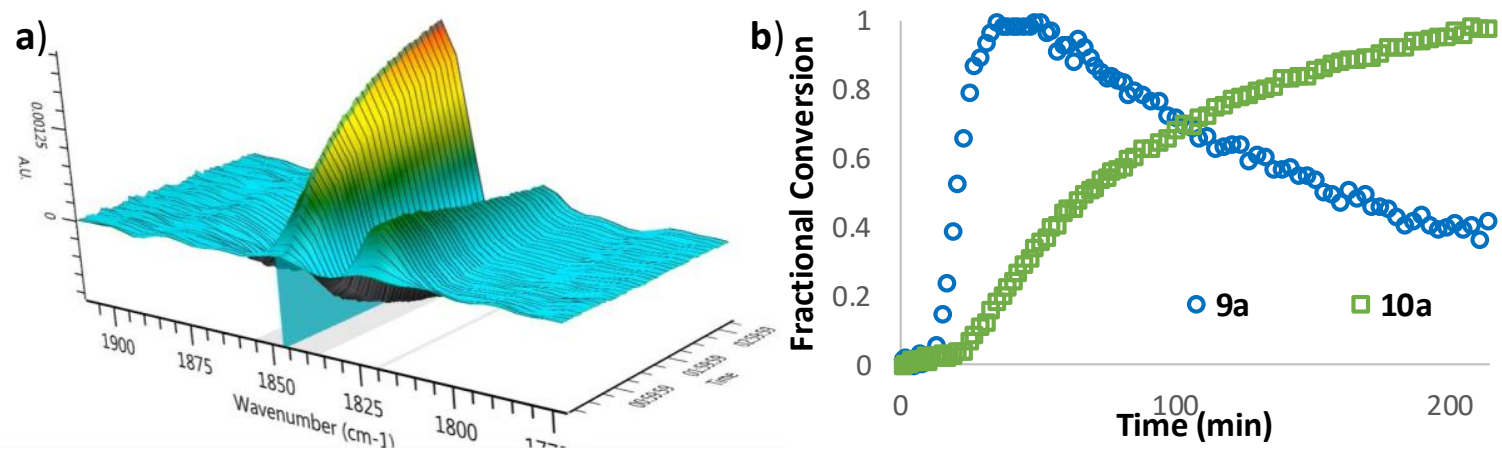

Figure S1 - a) Zoomed in region of waterfall plot to display the formation of anhydride 9a and acyl fluoride 10a; b) In situ ReactIR data displaying fractional conversion of anhydride 9a and acyl fluoride 10a as a function of time in the absence of a nucleophilic additive. 


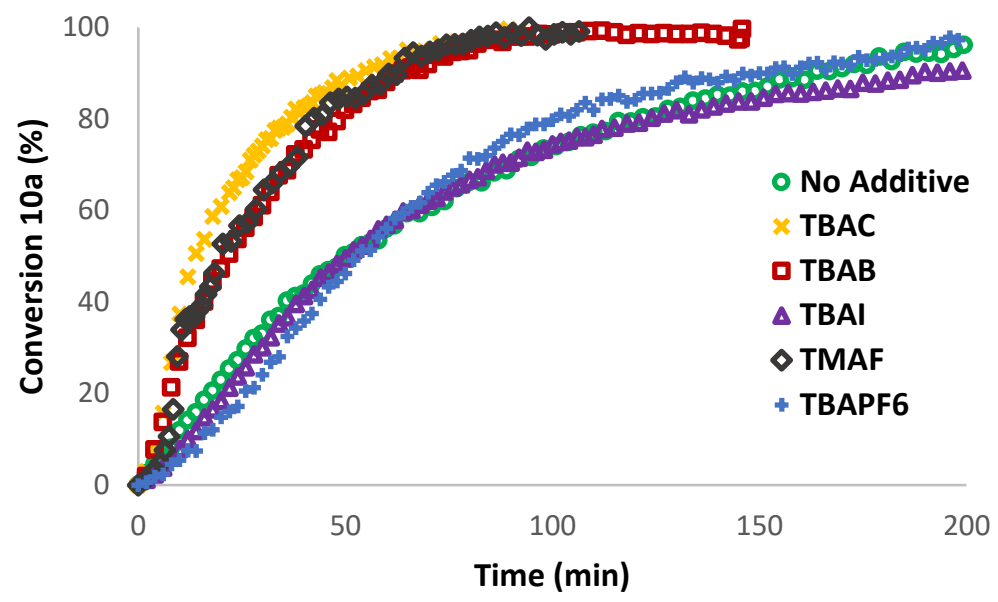

Figure S2 - ReactIR data plotting the conversion of 1a to 10a as a function of time for six different reactions: No additive, tetrabutylammonium chloride (TBAC), tetrabutylammonium bromide (TBAB), tetrabutylammonium iodide (TBAI), tetramethylammonium fluoride (TMAF) and tetrabutylammonium hexafluorophosphate (TBAPF 6 ). 


\section{COPASI Model}

The following model was created in COPASI comprised of the following elementary steps

1)

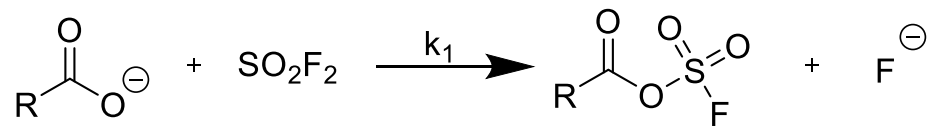

$\mathrm{k}_{1}=0.352$

2)

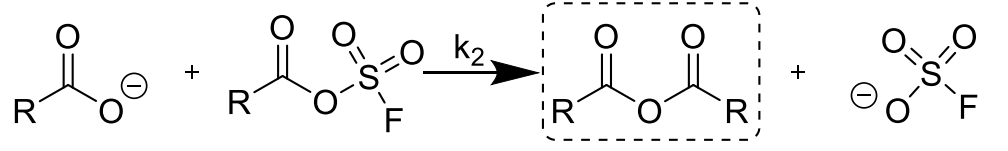

$\mathrm{k}_{2}=3.447 \mathrm{e}-6$

3)

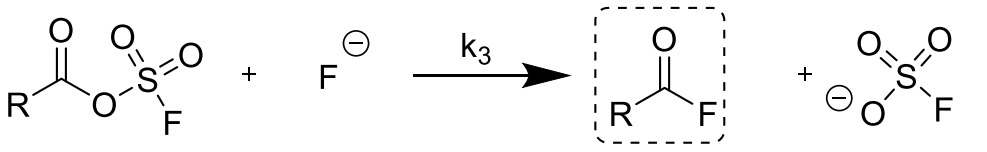

4)

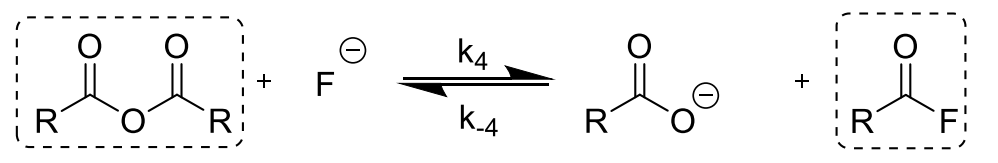

5)

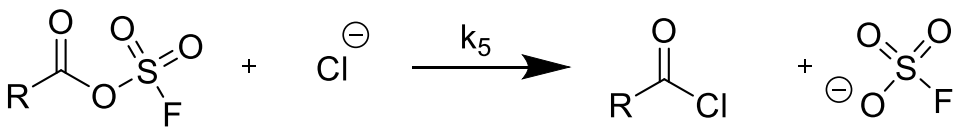

6)

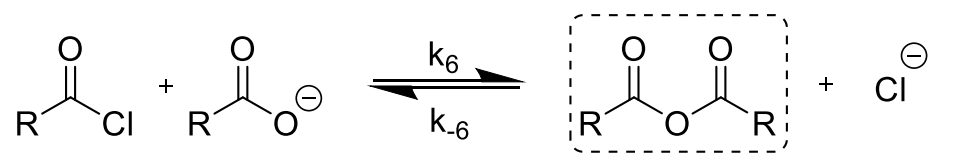

7)

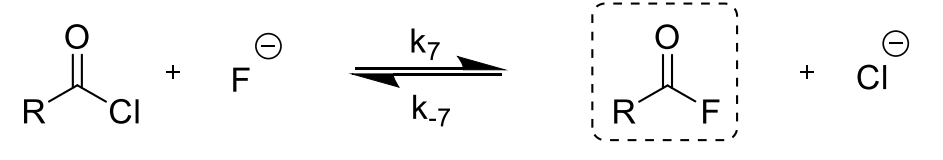

8)

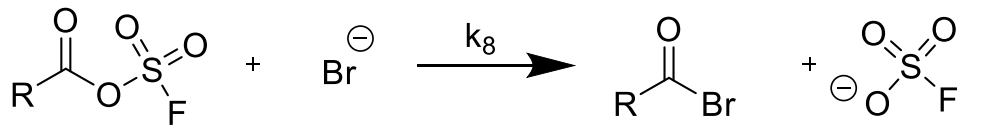

9)

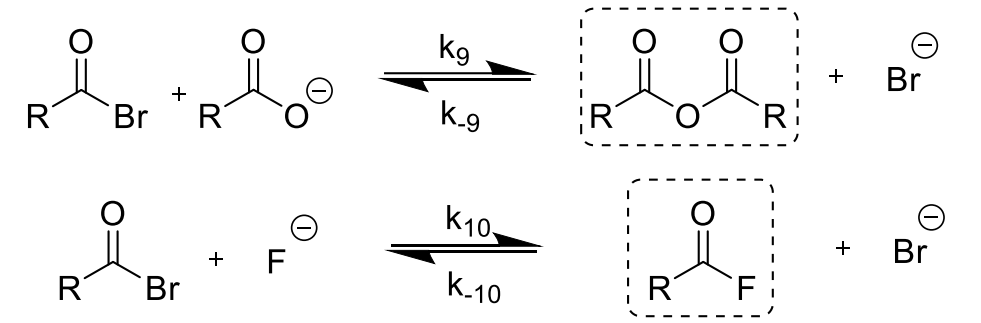

$\mathrm{k}_{9}=0.096$

$\mathrm{k}_{-9}=5285.354$

$\mathrm{k}_{10}=995260.309$

$\mathrm{k}_{-10}=9.084$ e-6 
Listed rate constants were generated through the parameter estimation workflow in COPASI, where the time-course concentrations of intermediate anhydride (9) and product acyl fluoride (10) were fit using an evolutionary programming method with a population size of 50 and 200000 generations. Input experimental data was obtained from three independent reactions, holding the concentration of carboxylic acid and $\mathrm{SO}_{2} \mathrm{~F}_{2}$ constant, allowing only the nature of the halide additive to be varied. Thus, the absolute values of the listed constants are not unique, but rather reflect the relative magnitudes of the rate constants in the elementary steps. Individual comparison of experimental (marks) and fitted (line) data are displayed below

Experiment 1: $[\mathrm{RCOOH}]=0.1 \mathrm{M} ;\left[\mathrm{SO}_{2} \mathrm{~F}_{2}\right]=0.3 \mathrm{M}-$ no additive

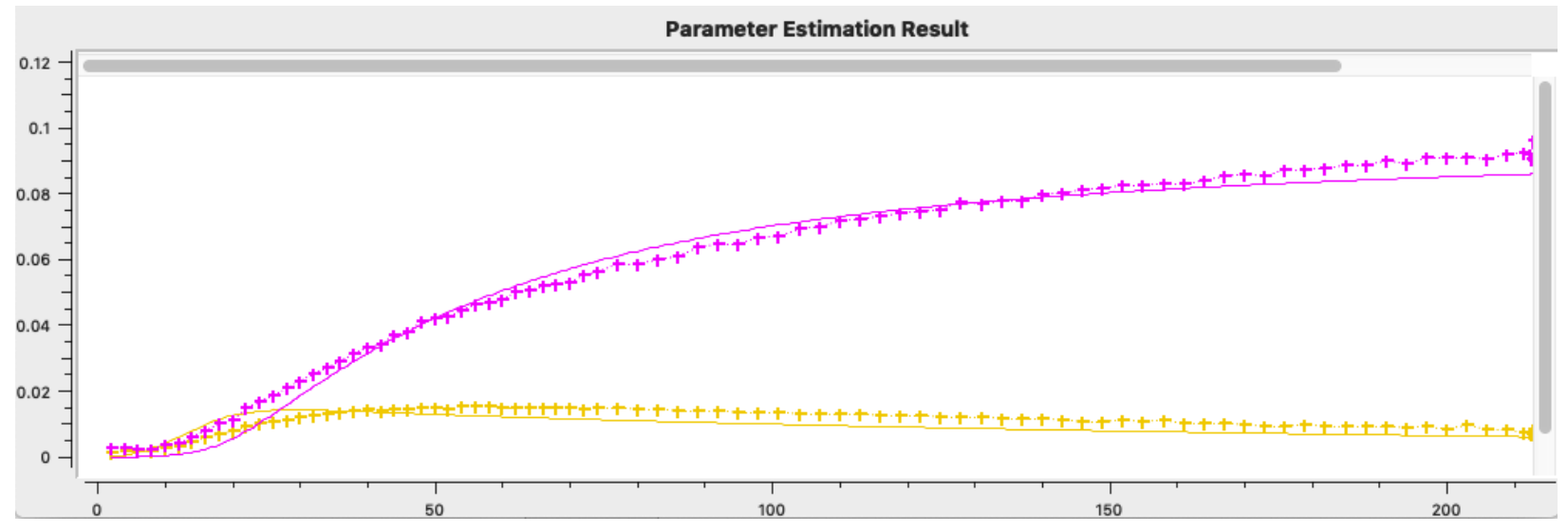

$=[$ anhydride 9]; +* = [acyl fluoride 10 $]$

Experiment 2: $[\mathrm{RCOOH}]=0.1 \mathrm{M} ;\left[\mathrm{SO}_{2} \mathrm{~F}_{2}\right]=0.3 \mathrm{M} ;[\mathrm{TBAB}]=0.1 \mathrm{M}$

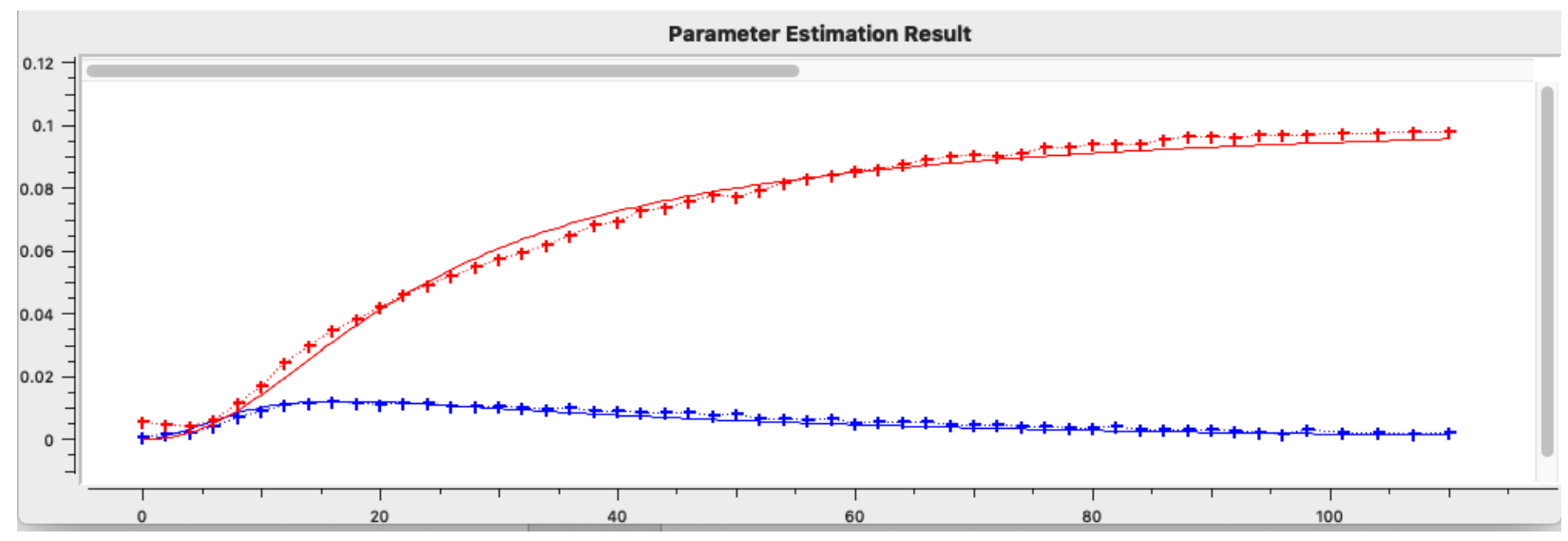

${ }^{+*}=$ [anhydride 9]; +* = [acyl fluoride 10] 
Experiment 3: $[\mathrm{RCOOH}]=0.1 \mathrm{M} ;\left[\mathrm{SO}_{2} \mathrm{~F}_{2}\right]=0.3 \mathrm{M} ;[\mathrm{TBAC}]=0.1 \mathrm{M}$

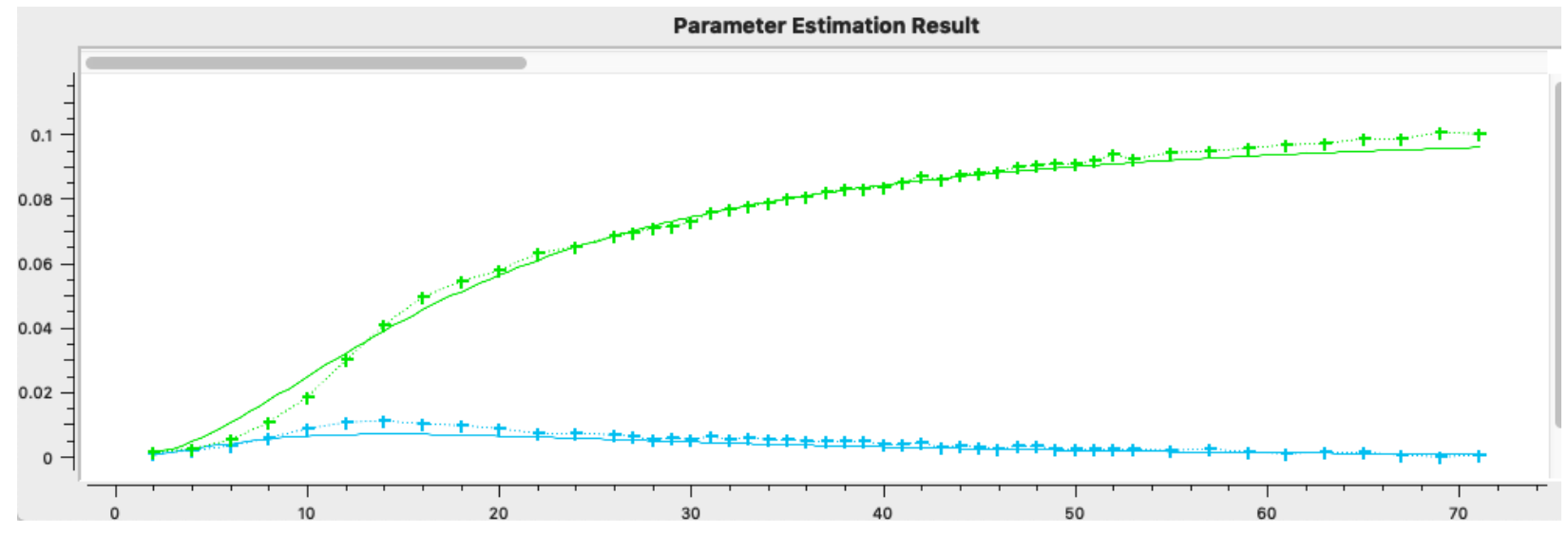

$+=$ [anhydride 9]; + = [acyl fluoride 10]

\section{Investigations into the formation of mixed sulfuryl halide}

Two 1 dram vials, equipped with magnetic stir-bars, were capped with septum-fitted vial caps and connected by a polyethylene tube. Vial A was charged with SDI (1.73 mmol, 5.77 equiv) and anhydrous KF (4.65 mmol, 15.5 equiv). To vial B was added TBAC $(0.30 \mathrm{mmol}, 1$ equiv) and $A C N-d^{3}(2 \mathrm{~mL})$. The reaction vial (B) was heated to $40^{\circ} \mathrm{C}$ and then the polyethylene tube in vial $B$ was immersed into the solution. To vial $A$ was added TFA $(1.00 \mathrm{~mL})$ in one portion. Vigorous bubbling of $\mathrm{SO}_{2} \mathrm{~F}_{2}$ was observed in vial $\mathrm{B}$ for 1 minute and when the bubbling subsided, vial $\mathrm{B}$ was vented via a needle for approximately 30 seconds (this triggered more bubbling of $\mathrm{SO}_{2} \mathrm{~F}_{2}$ through the solution). The polyethylene tubing and needle were removed and the reaction mixture in vial B was stirred at $40^{\circ} \mathrm{C}$. $\mathrm{PhCF}_{3}(37 \mu \mathrm{L}, 1$ equiv) was added to the reaction mixture as an internal standard. At 5 minutes, the reaction was analyzed by ${ }^{19} \mathrm{~F} \mathrm{NMR}$ spectroscopy at $23^{\circ} \mathrm{C}$. $\mathrm{SO}_{2} \mathrm{~F}_{2}$ (+33.7 ppm), $\mathrm{PhCF}_{3}(-63.15 \mathrm{ppm})$ and some TFA were observed, however, no $\mathrm{SO}_{2} \mathrm{ClF}$ was observed at a chemical shift of $+100 \mathrm{ppm} .{ }^{1}$ DIPEA ( $0.92 \mathrm{mmol}, 3$ equiv) was added to capture small amounts of transferred TFA from vial A. The reaction mixture was analyzed again by ${ }^{19} \mathrm{~F}$ NMR spectroscopy at 30 minutes. The ${ }^{19} \mathrm{~F}$ NMR analysis showed the presence of $\mathrm{FSO}_{3}{ }^{-}(+37.2$ ppm), which is likely due to hydrolysis of $\mathrm{SO}_{2} \mathrm{~F}_{2}$. However, still no $\mathrm{SO}_{2} \mathrm{ClF}$ was observed.

${ }^{1}$ Reddy, V. P.; Bellew, D. R.; Surya Prakash, G. K. J. Fluorine Chem. 1992, 56, 195-197. 


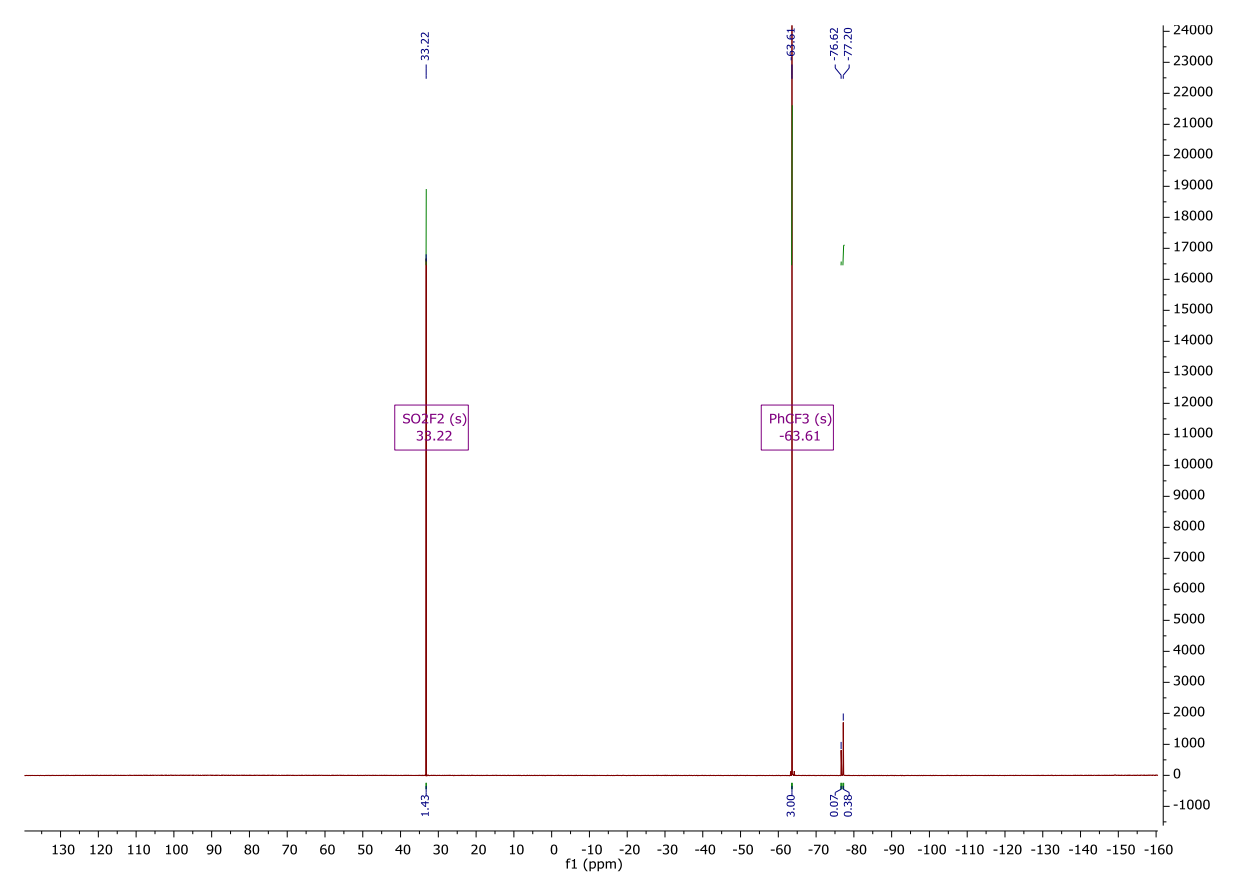

Figure S3 - quantitative ${ }^{19} \mathrm{~F}$ NMR spectrum of the mixed sulfuryl halide reaction mixture at 5 min

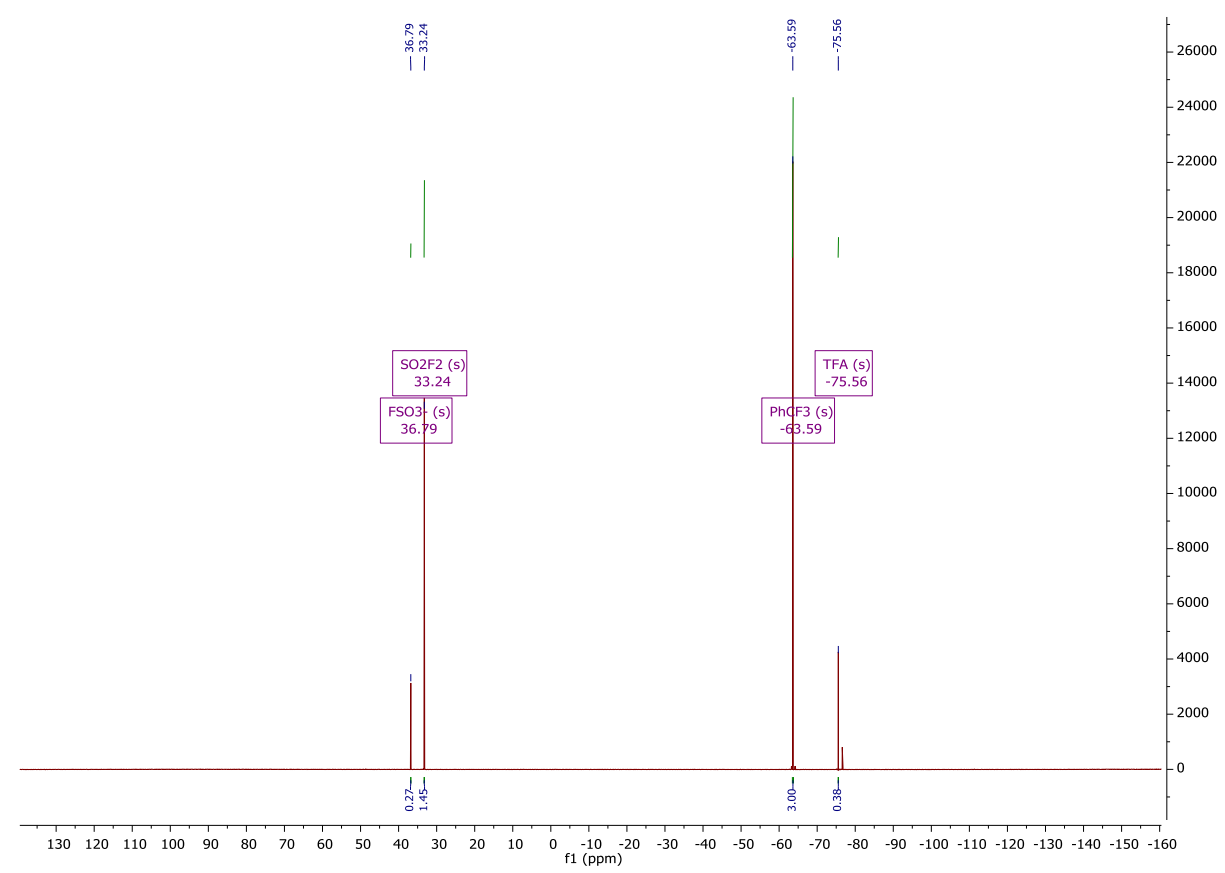

Figure S4 - quantitative ${ }^{19} \mathrm{~F}$ NMR spectrum of the mixed sulfuryl halide reaction at 30 min and after DIPEA was added 


\section{Carboxylic acid kinetic experiments monitored by ${ }^{19} \mathrm{~F}$ NMR spectroscopy}

Two 1 dram vials, equipped with magnetic stir-bars, were capped with septum-fitted vial caps and connected by a polyethylene tube. Vial A was charged with SDI (1.73 mmol, 5.77 equiv) and anhydrous KF (4.65 mmol, 15.5 equiv). To vial $B$ was added carboxylic acid $(0.30 \mathrm{mmol}, 1$ equiv), TBAC $(0.30 \mathrm{mmol}, 1$ equiv), dry ACN $(3.00 \mathrm{~mL})$, and DIPEA $(0.92 \mathrm{mmol}, 3.06$ equiv). The reaction vial (B) was heated to $40^{\circ} \mathrm{C}$ and then the polyethylene tube in vial $\mathrm{B}$ was immersed into the solution. To vial $A$ was added TFA $(1.00 \mathrm{~mL})$ in one portion. Vigorous bubbling of $\mathrm{SO}_{2} \mathrm{~F}_{2}$ and fuming were observed in vial $B$ for 1 minute and when the bubbling subsided, vial $B$ was vented via a needle for approximately 30 seconds (this triggered more bubbling of $\mathrm{SO}_{2} \mathrm{~F}_{2}$ through the solution). The polyethylene tubing and needle were removed and the reaction mixture in vial $\mathrm{B}$ was stirred at $40{ }^{\circ} \mathrm{C}$. $\mathrm{PhCF}_{3}(37 \mu \mathrm{L}, 1$ equiv) was added to the reaction as an internal standard and aliquots were taken and diluted in $\mathrm{CDCl}_{3}$ for quantitative ${ }^{19} \mathrm{~F}$ NMR spectroscopy.

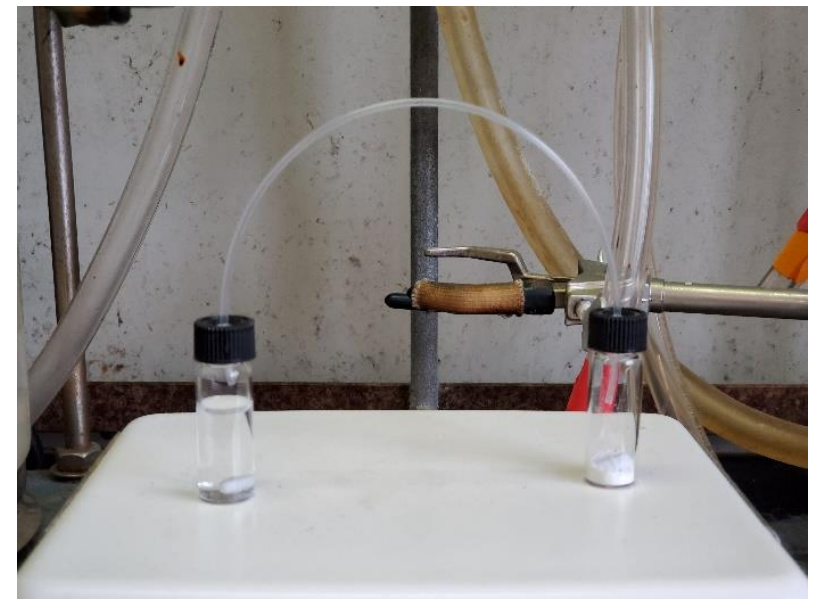

Figure S5 - Setup for the generation of $\mathrm{SO}_{2} \mathrm{~F}_{2}$ from $\mathrm{SDI}, \mathrm{KF}$, and TFA. Vial $\mathrm{A}\left(\mathrm{SO}_{2} \mathrm{~F}_{2}\right.$ generation) is on the right side, and vial $B$ (reaction vial) is on the left.

Caution: Reaction vials can become pressurized during the generation of $\mathrm{SO}_{2} \mathrm{~F}_{2}$. 


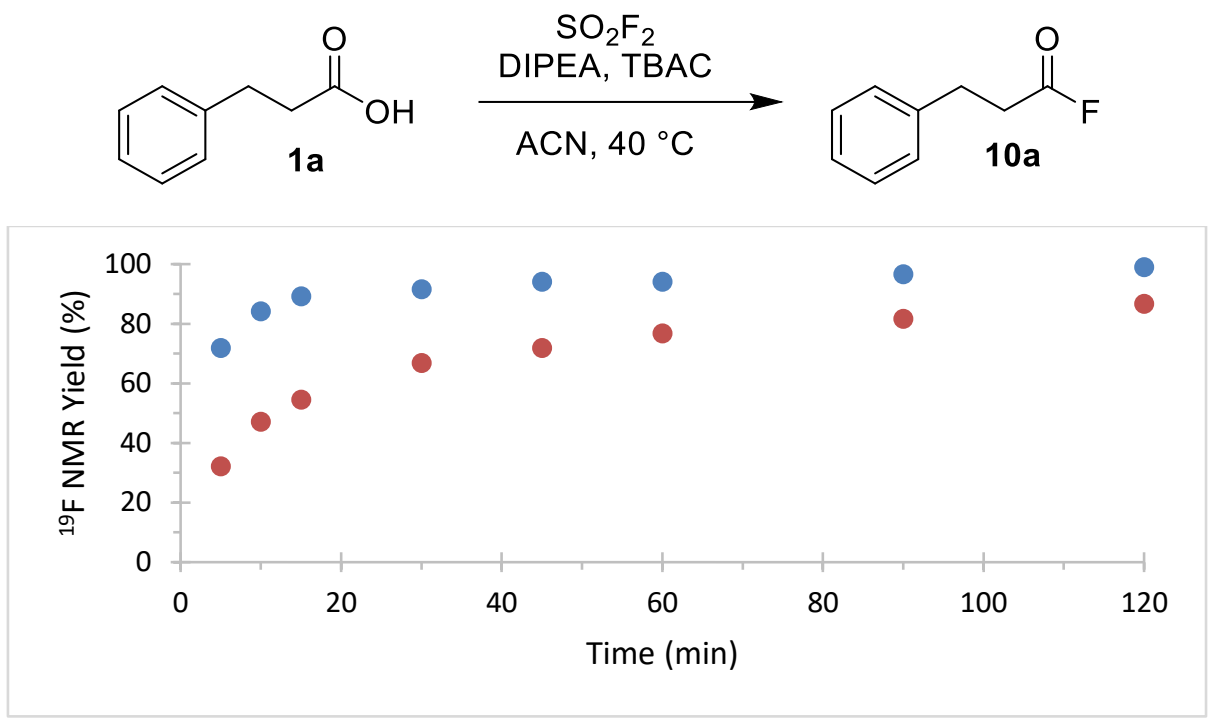

Figure S6 - ${ }^{19}$ F NMR spectroscopy kinetic study of the formation of 10a from 3-phenylpropionic acid, with and without TBAC additive. blue = with TBAC; red = without TBAC (control). Reactions were carried out in parallel on a $0.3 \mathrm{mmol}$ scale.

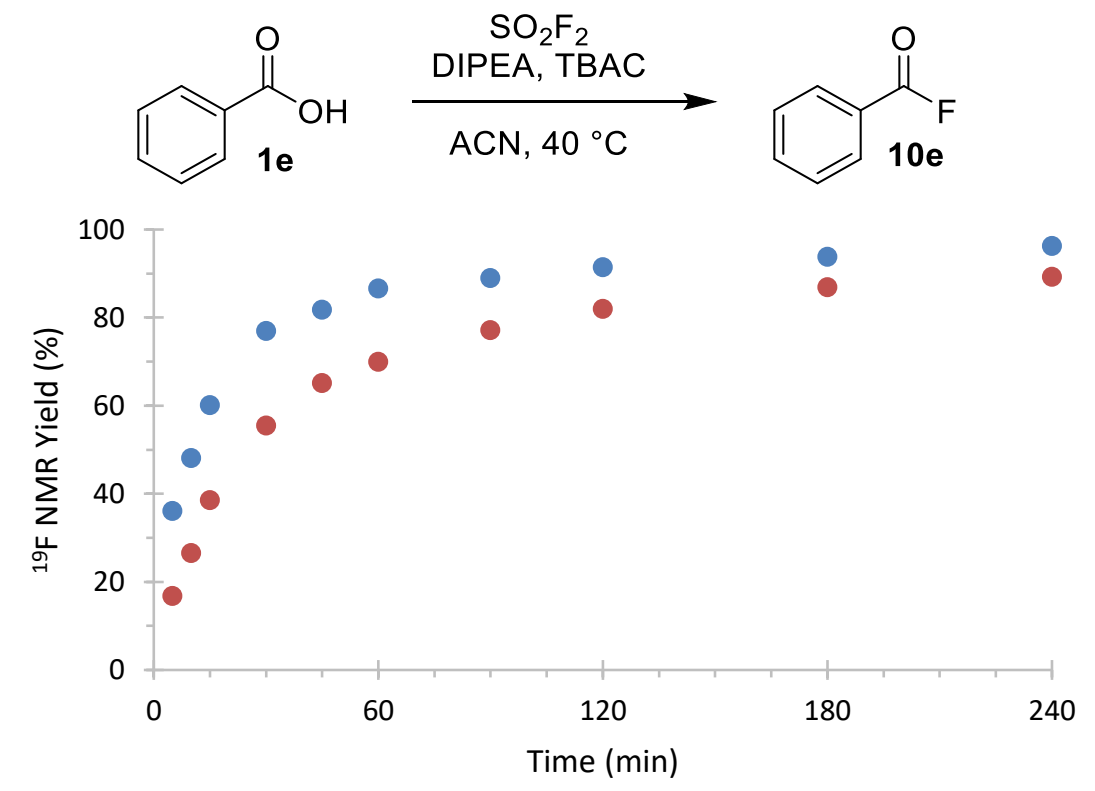

Figure S7 - ${ }^{19} \mathrm{~F}$ NMR spectroscopy kinetic study of the formation of 10e from benzoic acid, with and without TBAC additive. blue $=$ with TBAC; red $=$ without TBAC (control). Reactions were carried out in parallel on a $0.3 \mathrm{mmol}$ scale. 


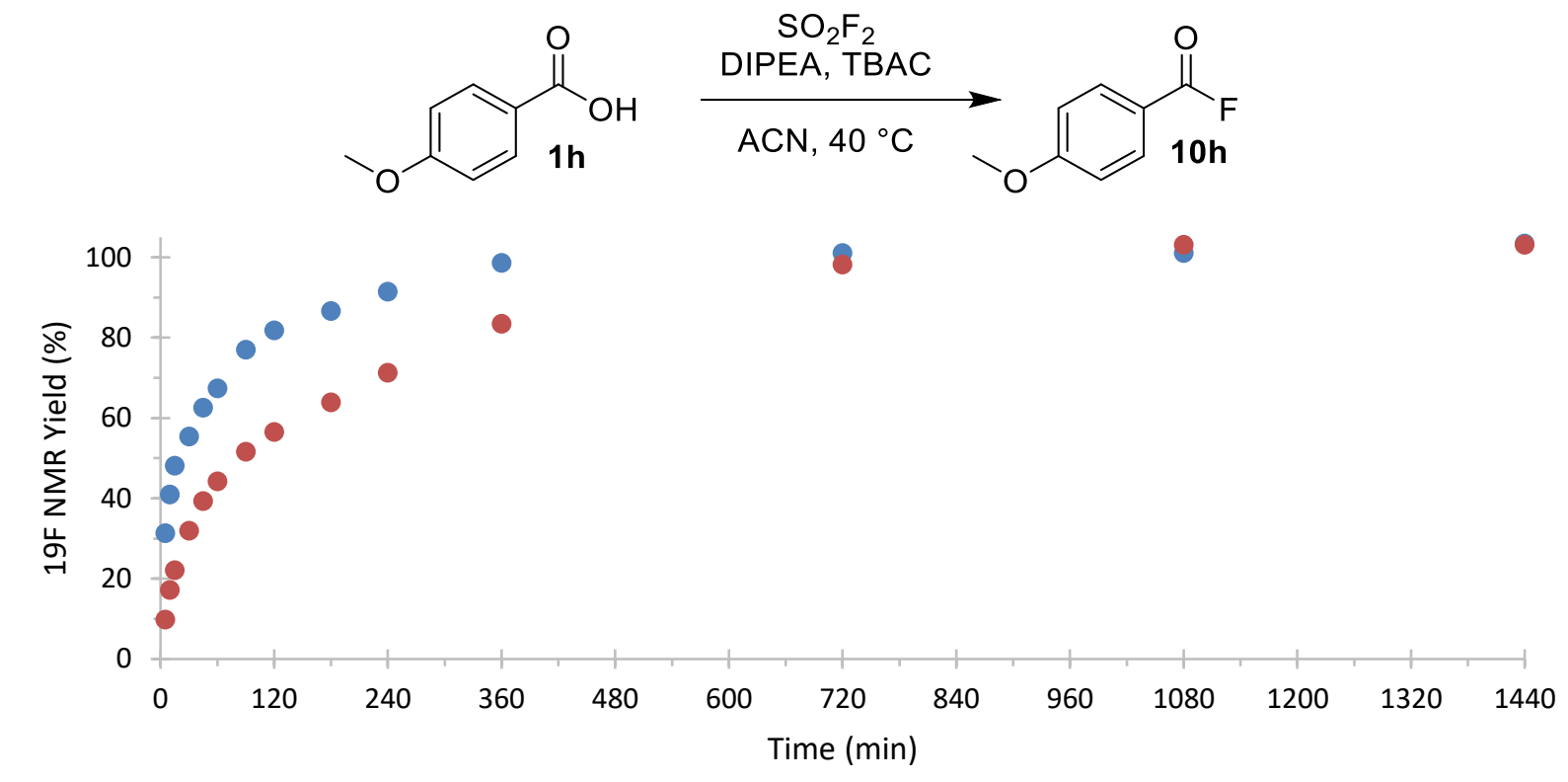

Figure S8 - ${ }^{19} \mathrm{~F}$ NMR spectroscopy kinetic study of the formation of $10 \mathrm{~h}$ from $p$-methoxybenzoic acid, with and without TBAC additive. blue = with TBAC; red = without TBAC (control). Reactions were carried out in parallel on a $0.3 \mathrm{mmol}$ scale. 
Reaction of carboxylic acid with sulfuryl chloride and tetramethylammonium fluoride (TMAF) monitored by ${ }^{19} \mathrm{~F}$ NMR spectroscopy

Scheme S2 - Reaction of 3-phenylpropionic acid with sulfuryl chloride and TMAF.<smiles>O=C(O)CCc1ccccc1</smiles><smiles>O=[W](F)(F)O[Na]</smiles><smiles>O=C(F)CCc1ccccc1</smiles>

A 1 dram vial, equipped with a magnetic stir-bar, was charged with carboxylic acid $(0.30 \mathrm{mmol}, 1$ equiv), TMAF (0.30 mmol, 1 equiv), dry ACN (3.00 mL), and DIPEA (0.92 mmol, 3.06 equiv). The reaction vial was heated to $40^{\circ} \mathrm{C}$. Sulfuryl chloride $(0.45 \mathrm{mmol}, 1.5$ equiv) was added to the vial via syringe and the reaction stirred at $40^{\circ} \mathrm{C}^{\circ} \mathrm{PhCF}_{3}(37 \mu \mathrm{L}, 1.0$ equiv) was added to the reaction as an internal standard and aliquots were taken and diluted in $\mathrm{CDCl}_{3}$ for quantitative ${ }^{19} \mathrm{~F}$ NMR spectroscopy. After 5 minutes, the yield of $10 \mathrm{a}$ was $\sim 20 \%$ and a small amount of $\mathrm{FSO}_{3}{ }^{-}$was observed $(<10 \%)$ by ${ }^{19} \mathrm{~F}$ NMR spectroscopy. The yield reached a maximum $\sim 22 \%$ after 60 minutes, and the ${ }^{1} \mathrm{H}$ NMR spectrum showed multiple unidentified byproducts.

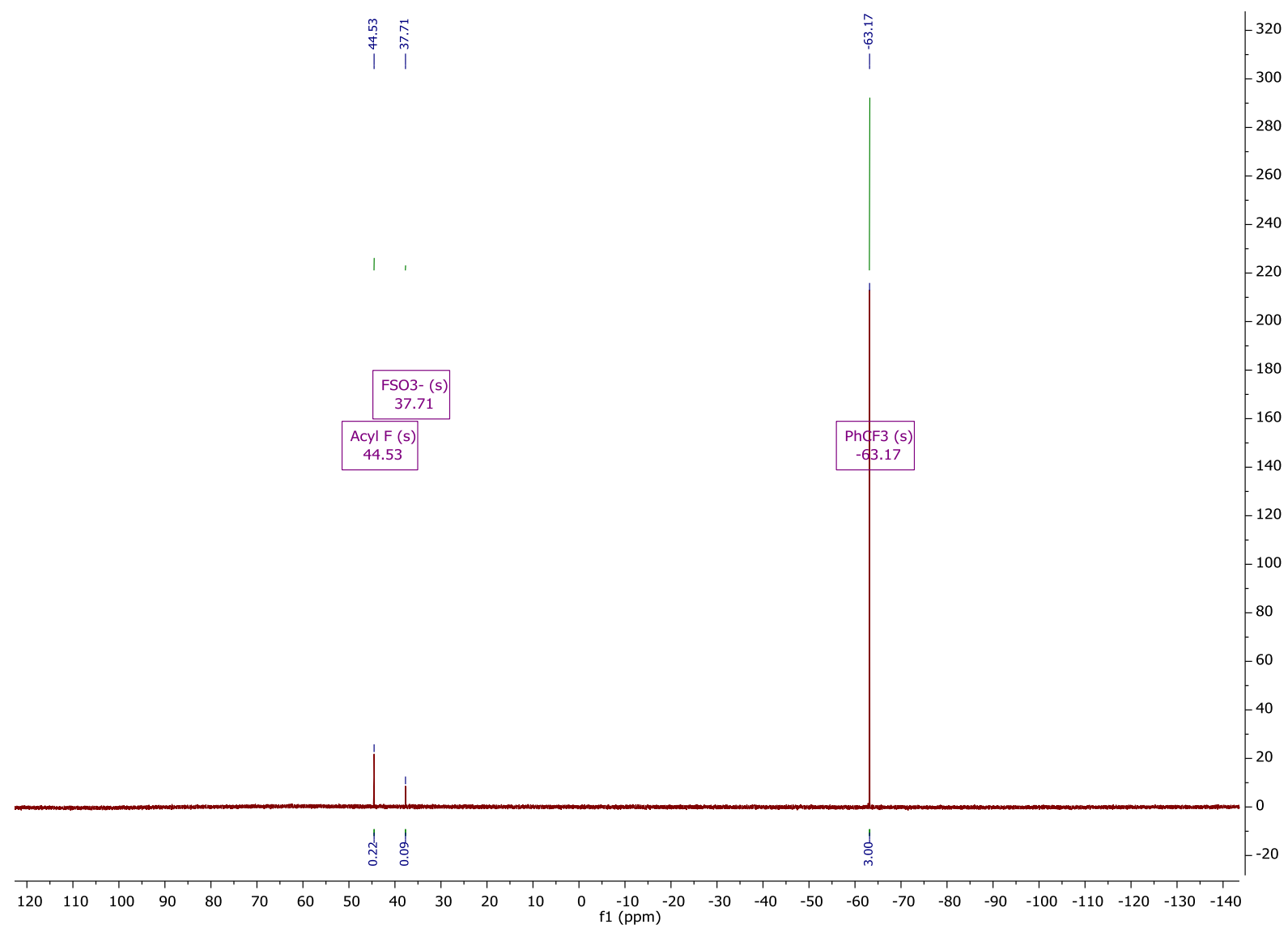

Figure S9-60 $\min { }^{19} \mathrm{~F}$ NMR spectrum for the reaction between 1a, sulfuryl chloride, and TMAF 


\section{General procedure for the conversion of carboxylic acids to acyl fluorides using $\mathrm{SO}_{2} \mathrm{~F}_{2}$}

Scheme S3 - One-pot conversion of carboxylic acids to acyl fluorides.

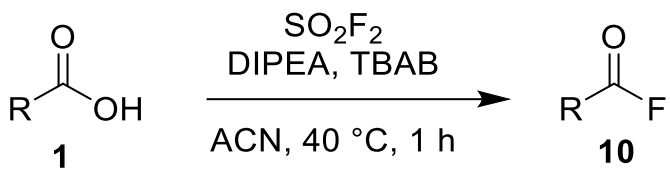

Two $20 \mathrm{~mL}$ scintillation vials, equipped with magnetic stir-bars, were capped with septum-fitted vial caps and connected by polyethylene tubing. Vial A was charged with SDI (5.05 mmol, 5.05 equiv) and anhydrous KF (13.8 mmol, 13.8 equiv). To vial B was added carboxylic acid (1.00 mmol, 1 equiv), TBAB (1.00 mmol, 1 equiv), dry ACN (10.0 mL), and DIPEA (3.00 mmol, 3.00 equiv). The reaction vial (B) was heated to $40{ }^{\circ} \mathrm{C}$, and then the polyethylene tube in vial $\mathrm{B}$ was immersed into the solution. To vial A was added TFA $(2.60 \mathrm{~mL})$ in one portion. Vigorous bubbling of $\mathrm{SO}_{2} \mathrm{~F}_{2}$ and fuming were observed in vial $\mathrm{B}$ for 1-2 minutes and when the bubbling subsided, vial $\mathrm{B}$ was vented via a needle for approximately 1 minute (this triggered more bubbling of $\mathrm{SO}_{2} \mathrm{~F}_{2}$ through the solution). The polyethylene tubing and needle were removed and the mixture in vial B was stirred at $40^{\circ} \mathrm{C}$ for 1 hour.

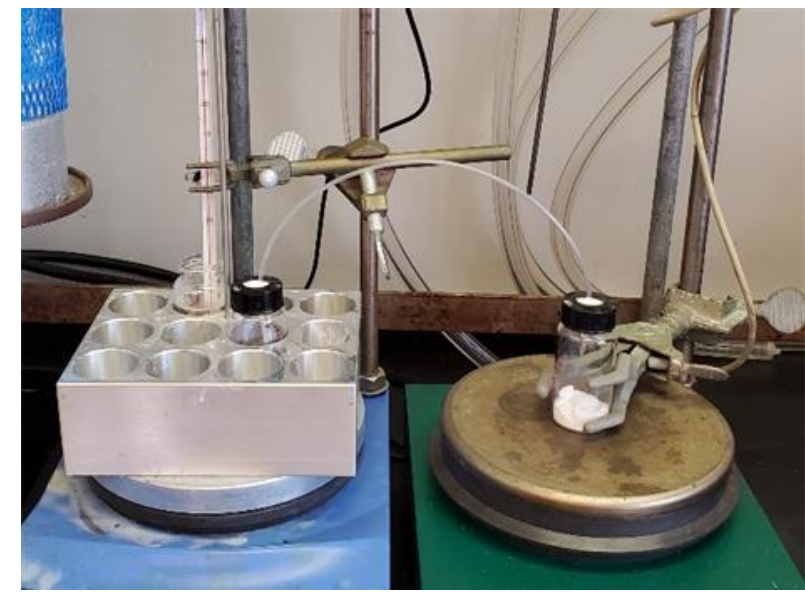

Figure $\mathrm{S} 10$ - Setup for the generation of $\mathrm{SO}_{2} \mathrm{~F}_{2}$ from $\mathrm{SDI}, \mathrm{KF}$, and TFA. Vial $\mathrm{A}\left(\mathrm{SO}_{2} \mathrm{~F}_{2}\right.$ generation) is on the right side, and vial $B$ (reaction vial) is on the left.

Caution: Reaction vials can become pressurized during the generation of $\mathrm{SO}_{2} \mathrm{~F}_{2}$.

workup: The reaction mixture was diluted with dichloromethane (DCM, $20 \mathrm{~mL}$ ) and then washed with $10 \%$ sat. aqueous $\mathrm{NaHCO}_{3}$ solution $(50 \mathrm{~mL})$. The aqueous layer was extracted twice with $\operatorname{DCM}(20 \mathrm{~mL})$ and the combined organic layers were dried over anhydrous $\mathrm{Na}_{2} \mathrm{SO}_{4}$. The organic layer was decanted, and the solvent was removed in vacuo. A pad of silica gel (Davisil Grade 633) was prepared on a fine fritted funnel $(2 \mathrm{~cm}$ thick $\times 2 \mathrm{~cm}$ diameter) and the crude residue was filtered through using an appropriate solvent. The filtrate was concentrated in vacuo using an oven-dried round bottom flask. Then the product was transferred to a vial and the solvent was removed in vacuo to afford the desired product. In some cases, a second filtration was required to further remove impurities. 


\section{General procedure for the acyl fluoride yields determined by ${ }^{19} \mathrm{~F}$ NMR spectroscopy}

Two 1 dram vials, equipped with magnetic stir-bars, were capped with septum-fitted vial caps and connected by a polyethylene tube. Vial A was charged with SDI (1.73 mmol, 5.77 equiv) and anhydrous KF (4.65 mmol, 15.5 equiv). To vial $B$ was added carboxylic acid $(0.30 \mathrm{mmol}, 1$ equiv), TBAB $(0.30 \mathrm{mmol}, 1$ equiv), dry ACN (3.00 mL), and DIPEA ( $0.92 \mathrm{mmol}, 3.06$ equiv). The reaction vial (B) was heated to $40^{\circ} \mathrm{C}$ and then the polyethylene tube in vial $\mathrm{B}$ was immersed into the solution. To vial $A$ was added TFA $(1.00 \mathrm{~mL})$ in one portion. Vigorous bubbling of $\mathrm{SO}_{2} \mathrm{~F}_{2}$ and fuming were observed in vial $B$ for 1 minute and when the bubbling subsided, vial $B$ was vented via a needle for approximately 30 seconds (this triggered more bubbling of $\mathrm{SO}_{2} \mathrm{~F}_{2}$ through the solution). The polyethylene tubing and needle were removed and the reaction mixture in vial $\mathrm{B}$ was stirred at $40{ }^{\circ} \mathrm{C}$ for 1 hour. $\mathrm{PhCF}_{3}(37 \mu \mathrm{L}, 1$ equiv) was added to the reaction as an internal standard and an aliquot was taken and diluted in $\mathrm{CDCl}_{3}$ for quantitative ${ }^{19} \mathrm{~F}$ NMR spectroscopy.

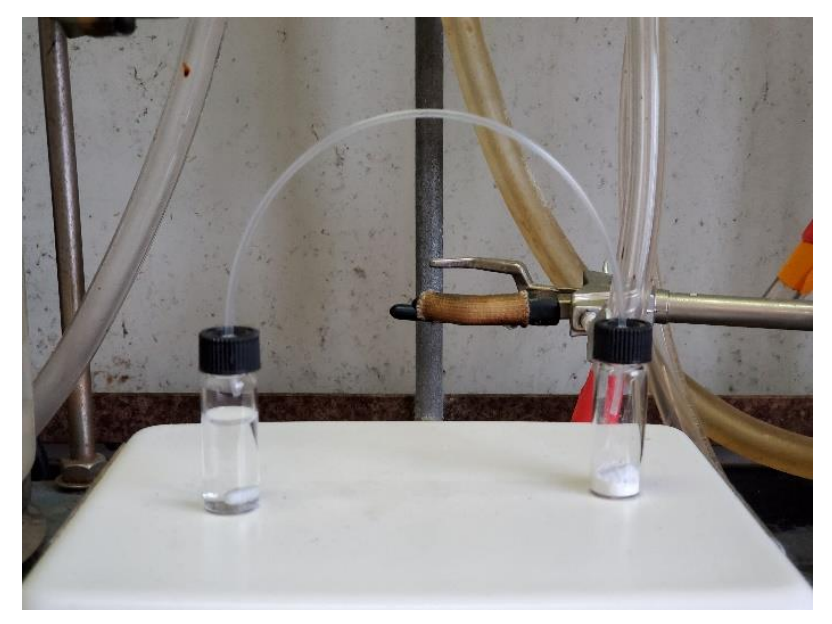

Figure $\mathrm{S} 11$ - Setup for the generation of $\mathrm{SO}_{2} \mathrm{~F}_{2}$ from $\mathrm{SDI}, \mathrm{KF}$, and TFA. Vial $\mathrm{A}\left(\mathrm{SO}_{2} \mathrm{~F}_{2}\right.$ generation) is on the right side, and vial $\mathrm{B}$ (reaction vial) is on the left.

Caution: Reaction vials can become pressurized during the generation of $\mathrm{SO}_{2} \mathrm{~F}_{2}$. 
General procedure for the synthesis of carboxylic acid derivatives by one-pot sequential protocol

Scheme S4 - Synthesis of carboxylic acid derivatives by one-pot sequential protocol.

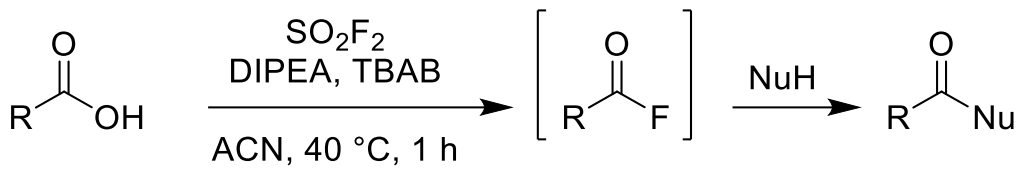

$\mathrm{Nu}$ : OSu, OPhth, NMeOMe, S-decyl

Two $20 \mathrm{~mL}$ vials, equipped with magnetic stir-bars, were capped with septum-fitted vial caps and connected by polyethylene tubing. Vial A was charged with SDI ( $5.05 \mathrm{mmol}, 5.05$ equiv) and anhydrous KF (13.8 mmol, 13.8 equiv). To vial $B$ was added carboxylic acid ( $1.00 \mathrm{mmol}, 1$ equiv), TBAB (1.00 mmol, 1 equiv), dry ACN (10.0 mL), and DIPEA (3.00 mmol, 3.00 equiv). The reaction vial $(B)$ was heated to $40^{\circ} \mathrm{C}$, and then the polyethylene tube in vial $B$ was immersed into the solution. To vial A was added TFA $(2.60 \mathrm{~mL})$ in one portion. Vigorous bubbling of $\mathrm{SO}_{2} \mathrm{~F}_{2}$ and fuming were observed in vial $B$ for 2-3 minutes and when the bubbling subsided, vial $B$ was vented via a needle for approximately 1 minute (this triggered more bubbling of $\mathrm{SO}_{2} \mathrm{~F}_{2}$ through the solution). The polyethylene tubing and needle were removed and the mixture in vial $\mathrm{B}$ was stirred at $40{ }^{\circ} \mathrm{C}$. After 1 hour, the reaction mixture was sparged with $\mathrm{N}_{2}$ gas for 2 minutes and then the nucleophile (1.20 mmol, 1.20 equiv) was added and the reaction stirred at ambient temperature for 1 hour.

Caution: Reaction vials become pressurized during the generation of $\mathrm{SO}_{2} \mathrm{~F}_{2}$. 


\section{3-phenylpropanoyl fluoride (10a)}<smiles>O=C(F)CCc1ccccc1</smiles>

3-Phenylpropionic acid $(1.00 \mathrm{mmol})$ was subjected to the general procedure for conversion of carboxylic acids to acyl fluorides using $\mathrm{SO}_{2} \mathrm{~F}_{2}$. Following the general workup, the residue was filtered through a pad of silica gel using pentanes $(70 \mathrm{~mL})$. The filtrate was concentrated and subjected to a second filtration. The product was obtained as a colorless oil (100 mg, $66 \%$ yield). The characterization data matched previously reported data. ${ }^{2}$

${ }^{1} \mathbf{H}$ NMR $\left(300 \mathrm{MHz}, \mathrm{CDCl}_{3}\right) \delta 7.48-7.15(\mathrm{~m}, 5 \mathrm{H}), 3.01$ (t, $\left.J=7.2 \mathrm{~Hz}, 2 \mathrm{H}\right), 2.84$ (td, $J=7.5,1.0$ $\mathrm{Hz}, 2 \mathrm{H}) ;{ }^{13} \mathbf{C}\{1 \mathrm{H}\}$ NMR $\left(75 \mathrm{MHz}, \mathrm{CDCl}_{3}\right) \delta 162.9(\mathrm{~d}, J=360.6 \mathrm{~Hz}), 139.0,128.9,128.4,126.9$, $34.0(\mathrm{~d}, J=50.4 \mathrm{~Hz}), 30.1(\mathrm{~d}, J=2.3 \mathrm{~Hz}) ;{ }^{19} \mathrm{~F}$ NMR $\left(282 \mathrm{MHz}, \mathrm{CDCl}_{3}\right) \delta+45.0 ; \mathrm{MS}-\mathrm{El}(\mathrm{m} / \mathrm{z}) 152.1$

\section{3-(2-bromophenyl)propanoyl fluoride (10b)}<smiles>O=C(F)CCc1ccccc1Br</smiles>

3-(2-bromophenyl)propionic acid $(1.00 \mathrm{mmol})$ was subjected to the general procedure for conversion of carboxylic acids to acyl fluorides using $\mathrm{SO}_{2} \mathrm{~F}_{2}$. Following the general workup, the residue was filtered through a pad of silica gel using petroleum ether $(80 \mathrm{~mL})$. The filtrate was concentrated and flushed through a silica gel pipette plug $(2 \mathrm{~cm})$. The product was obtained as a colorless oil (179 mg, 76\% yield). The characterization data matched previously reported data. ${ }^{3}$

${ }^{1} \mathrm{H}$ NMR $\left(300 \mathrm{MHz}, \mathrm{CDCl}_{3}\right) \delta 7.63-7.54(\mathrm{~m}, 1 \mathrm{H}), 7.35-7.23(\mathrm{~m}, 2 \mathrm{H}), 7.21-7.09(\mathrm{~m}, 1 \mathrm{H}), 3.12$ (t, $J=7.6 \mathrm{~Hz}, 2 \mathrm{H}), 2.87(\mathrm{t}, J=7.5 \mathrm{~Hz}, 2 \mathrm{H}) ;{ }^{13} \mathrm{C}\{1 \mathrm{H}\}$ NMR $\left(75 \mathrm{MHz} \mathrm{CDCl}_{3}\right) \delta 162.8(\mathrm{~d}, J=360.3$ $\mathrm{Hz}), 138.3,133.2,130.8,128.8,128.0,124.3,32.2(\mathrm{~d}, J=51.2 \mathrm{~Hz}), 30.7(\mathrm{~d}, J=2.9 \mathrm{~Hz}) ;{ }^{19} \mathrm{~F} \mathrm{NMR}$ $\left(282 \mathrm{MHz}, \mathrm{CDCl}_{3}\right) \delta+44.9$; MS-EI $(\mathrm{m} / \mathrm{z}) 230.0$

\section{adamantane-1-carbonyl fluoride (10c)}<smiles>O=C(F)C12CC3CC(CC(C3)C1)C2</smiles>

1-Adamantanecarboxylic acid $(1.00 \mathrm{mmol})$ was subjected to the general procedure for conversion of carboxylic acids to acyl fluorides using $\mathrm{SO}_{2} \mathrm{~F}_{2}$. Following the general workup, the residue was

\footnotetext{
2 Beaulieu, F.; Beauregard, L. -P.; Courchesne, G.; Couturier, M.; LaFlamme, F.; L'Heureux, A. Org. Lett. 2009, 11, 5050-5053.

${ }^{3}$ Scattolin, T.; Deckers, K.; Schoenebeck, F. Org. Lett. 2017, 19, 5740-5743.
} 
filtered through a pad of silica gel using pentanes $(50 \mathrm{~mL})$. The product was obtained as a low melting white solid (112 mg, 61\% yield). The characterization data matched previously reported data. $^{4}$

${ }^{1} \mathrm{H}$ NMR $\left(300 \mathrm{MHz}, \mathrm{CDCl}_{3}\right) \delta 2.14-2.01(\mathrm{~m}, 3 \mathrm{H}), 2.00-1.94(\mathrm{~m}, 6 \mathrm{H}), 1.81-1.65(\mathrm{~m}, 6 \mathrm{H})$; ${ }^{13} \mathbf{C}\{1 \mathrm{H}\}$ NMR $\left(75 \mathrm{MHz}, \mathrm{CDCl}_{3}\right) \delta 167.2(\mathrm{~d}, J=371.8 \mathrm{~Hz}), 40.6(\mathrm{~d}, J=44.4 \mathrm{~Hz}), 38.0,36.2,27.5$;

${ }^{19} \mathrm{~F}$ NMR $\left(282 \mathrm{MHz} \mathrm{CDCl}_{3}\right) \delta+23.5$; MS-EI $(\mathrm{m} / \mathrm{z}) 182.2$

\section{cinnamoyl fluoride (10d)}<smiles>O=C(F)/C=C/c1ccccc1</smiles>

trans-Cinnamic acid $(1.00 \mathrm{mmol})$ was subjected to the general procedure for conversion of carboxylic acids to acyl fluorides using $\mathrm{SO}_{2} \mathrm{~F}_{2}$. The reaction was stirred at $40{ }^{\circ} \mathrm{C}$ at 2 hours. Following the general workup, the residue was filtered through a pad of silica gel using pentanes $(120 \mathrm{~mL})$. The filtrate was concentrated and subjected to a second filtration. The product was obtained as a low melting white solid (112 $\mathrm{mg}, 75 \%$ yield). The characterization data matched previously reported data. ${ }^{4}$

${ }^{1} \mathbf{H}$ NMR $\left(300 \mathrm{MHz}, \mathrm{CDCl}_{3}\right) \delta 7.85(\mathrm{~d}, J=16.0 \mathrm{~Hz}, 1 \mathrm{H}), 7.62-7.51(\mathrm{~m}, 2 \mathrm{H}), 7.51-7.37(\mathrm{~m}, 3 \mathrm{H})$, $6.38(\mathrm{dd}, J=16.0,7.3 \mathrm{~Hz}, 1 \mathrm{H}) ;{ }^{13} \mathbf{C}\{\mathbf{1 H}\} \mathbf{N M R}\left(101 \mathrm{MHz}, \mathrm{CDCl}_{3}\right) \delta 157.2(\mathrm{~d}, J=338.5 \mathrm{~Hz}), 151.5$ $(\mathrm{d}, J=6.1 \mathrm{~Hz}), 133.3,132.0,129.3,128.9,112.3(\mathrm{~d}, J=67.2 \mathrm{~Hz}) ;{ }^{19} \mathrm{~F} \mathbf{N M R}\left(282 \mathrm{MHz}, \mathrm{CDCl}_{3}\right) \delta$ +25.2 (d, J = 7.3 Hz); MS-EI ( $\mathrm{m} / \mathrm{z}) 150.1$

\section{benzoyl fluoride (10e)}<smiles>O=C(F)c1ccccc1</smiles>

Benzoic acid $(1.00 \mathrm{mmol})$ was subjected to the general procedure for conversion of carboxylic acids to acyl fluorides using $\mathrm{SO}_{2} \mathrm{~F}_{2}$. Following the general workup, the residue was filtered through a pad of silica gel using pentanes $(50 \mathrm{~mL})$. The product was obtained as a colorless oil (36 $\mathrm{mg}$, $30 \%$ yield). The low yield is largely due to the volatility of the product. The characterization data matched previously reported data. ${ }^{2}$

${ }^{1} \mathbf{H}$ NMR $\left(300 \mathrm{MHz}, \mathrm{CDCl}_{3}\right) \delta 8.06(\mathrm{~d}, J=7.5 \mathrm{~Hz}, 2 \mathrm{H}), 7.71(\mathrm{t}, J=7.5 \mathrm{~Hz}, 1 \mathrm{H}), 7.53(\mathrm{t}, J=7.7 \mathrm{~Hz}$, $2 \mathrm{H}) ;{ }^{13} \mathrm{C}\{1 \mathrm{H}\}$ NMR $\left(75 \mathrm{MHz}, \mathrm{CDCl}_{3}\right) \delta 157.6(\mathrm{~d}, J=344.4 \mathrm{~Hz}), 135.4,131.6(\mathrm{~d}, J=4.1 \mathrm{~Hz}), 129.2$, $125.1(\mathrm{~d}, J=60.8 \mathrm{~Hz}) ;{ }^{19} \mathrm{~F}$ NMR $\left(282 \mathrm{MHz}, \mathrm{CDCl}_{3}\right) \delta+17.7$; MS-EI $(\mathrm{m} / \mathrm{z}) 124.1$

${ }^{4}$ Munoz, S. B.; Dang, H.; Ispizua-Rodriguez, X.; Mathew, T.; Surya Prakash, G. K. Org. Lett. 2019, 21, 1659-1663. 


\section{4-methylbenzoyl fluoride (10f)}<smiles>Cc1ccc(C(=O)F)cc1</smiles>

4-Methylbenzoic acid $(1.00 \mathrm{mmol})$ was subjected to the general procedure for conversion of carboxylic acids to acyl fluorides using $\mathrm{SO}_{2} \mathrm{~F}_{2}$. Following the general workup, the residue was filtered through a pad of silica gel using pentanes $(50 \mathrm{~mL})$. The filtrate was concentrated and subjected to a second filtration. The product was obtained as a colorless oil ( $79 \mathrm{mg}, 57 \%$ yield). The characterization data matched previously reported data. ${ }^{5}$

${ }^{1} \mathrm{H}$ NMR $\left(300 \mathrm{MHz}, \mathrm{CDCl}_{3}\right) \delta 7.92(\mathrm{~d}, J=8.2 \mathrm{~Hz}, 2 \mathrm{H}), 7.31(\mathrm{~d}, J=8.0 \mathrm{~Hz}, 2 \mathrm{H}), 2.45(\mathrm{~s}, 3 \mathrm{H})$; ${ }^{13} \mathrm{C}\{1 \mathrm{H}\}$ NMR $\left(75 \mathrm{MHz}, \mathrm{CDCl}_{3}\right) \delta 157.6(\mathrm{~d}, J=342.7 \mathrm{~Hz}), 146.7,131.6(\mathrm{~d}, J=4.2 \mathrm{~Hz}), 129.9$ (d, $J=1.3 \mathrm{~Hz}), 122.2(\mathrm{~d}, J=61.0 \mathrm{~Hz}), 22.0 ;{ }^{19} \mathrm{~F} \mathrm{NMR}\left(282 \mathrm{MHz} \mathrm{CDCl}_{3}\right) \delta+17.0 ; \mathrm{MS}-\mathrm{El}(\mathrm{m} / \mathrm{z}) 138.1$

\section{4-chlorobenzoyl fluoride $(\mathbf{1 0 g})$}<smiles>O=C(F)c1ccc(Cl)cc1</smiles>

4-Chlorobenzoic acid $(1.00 \mathrm{mmol})$ was subjected to the general procedure for conversion of carboxylic acids to acyl fluorides using $\mathrm{SO}_{2} \mathrm{~F}_{2}$. Following the general workup, the combined organic layer was washed with $50 \%$ brine and then dried over anhydrous $\mathrm{Na}_{2} \mathrm{SO}_{4}$. The residue was filtered through a pad of silica gel using petroleum ether $(65 \mathrm{~mL})$. The product was obtained as a white solid (86 mg, 54\% yield). The characterization data matched previously reported data. ${ }^{3}$

${ }^{1} \mathbf{H}$ NMR $\left(300 \mathrm{MHz}, \mathrm{CDCl}_{3}\right) \delta 8.02-7.94(\mathrm{~m}, 2 \mathrm{H}), 7.60-7.41(\mathrm{~m}, 2 \mathrm{H}) ;{ }^{13} \mathbf{C}\{\mathbf{1 H}\} \mathbf{N M R}(75 \mathrm{MHz}$, $\left.\mathrm{CDCl}_{3}\right) \delta 156.7(\mathrm{~d}, J=343.5 \mathrm{~Hz}), 142.4,132.9(\mathrm{~d}, J=3.9 \mathrm{~Hz}), 129.7,123.5(\mathrm{~d}, J=62.6 \mathrm{~Hz}) ;{ }^{19} \mathrm{~F}$ NMR $\left(282 \mathrm{MHz}, \mathrm{CDCl}_{3}\right) \delta+18.0$; MS-EI $(\mathrm{m} / \mathrm{z}) 158.1$

\section{4-methoxybenzoyl fluoride (10h)}<smiles>COc1ccc(C(=O)F)cc1</smiles>

4-Methoxybenzoic acid $(1.00 \mathrm{mmol})$ was subjected to the general procedure for conversion of carboxylic acids to acyl fluorides using $\mathrm{SO}_{2} \mathrm{~F}_{2}$. The reaction was stirred at $40{ }^{\circ} \mathrm{C}$ at 3 hours. Following the general workup, the residue was filtered through a pad of silica gel using $10 \%$ diethyl

${ }^{5}$ Wang, Z.; Wang, X.; Nishihara, Y. Chem. Commun. 2018, 54, 13969-13972. 
ether in petroleum ether (40 mL). The product was obtained as a colorless oil (125 mg, 80\% yield). The characterization data matched previously reported data. ${ }^{4}$

${ }^{1} \mathbf{H}$ NMR $\left(300 \mathrm{MHz}, \mathrm{CDCl}_{3}\right) \delta 8.03-7.92(\mathrm{~m}, 2 \mathrm{H}), 7.03-6.91(\mathrm{~m}, 2 \mathrm{H}), 3.89(\mathrm{~s}, 3 \mathrm{H}) ;{ }^{13} \mathbf{C}\{\mathbf{1 H}\} \mathbf{N M R}$ $\left(75 \mathrm{MHz} \mathrm{CDCl}_{3}\right) \delta$ 165.3, 157.4 (d, $\left.J=339.8 \mathrm{~Hz}\right), 133.9$ (d, $\left.J=4.2 \mathrm{~Hz}\right), 117.0$ (d, J = 61.8 Hz), 114.6, 55.8; ${ }^{19}$ F NMR (282 MHz, $\left.\mathrm{CDCl}_{3}\right) \delta+15.5$; MS-EI $(\mathrm{m} / \mathrm{z}) 154.1$

\section{4-nitrobenzoyl fluoride (10i)}<smiles>O=C(F)c1ccc([N+](=O)[O-])cc1</smiles>

4-Nitrobenzoic acid $(1.00 \mathrm{mmol})$ was subjected to the general procedure for conversion of carboxylic acids to acyl fluorides using $\mathrm{SO}_{2} \mathrm{~F}_{2}$. The reaction was stirred at $40{ }^{\circ} \mathrm{C}$ at 6 hours. The volatiles were removed in vacuo and the resulting residue was filtered through a pad of silica gel $(2.5 \mathrm{~cm}$ thick $\times 2 \mathrm{~cm}$ diameter) using $50 \%$ dichloromethane in pentanes $(25 \mathrm{~mL})$. The filtrate was concentrated and subjected to a second filtration. The product was obtained as a pale orange solid (118 mg, 69\% yield). The characterization data matched previously reported data. ${ }^{3}$

${ }^{1} \mathbf{H}$ NMR $\left(300 \mathrm{MHz}, \mathrm{CDCl}_{3}\right) \delta 8.42-8.35(\mathrm{~m}, 2 \mathrm{H}), 8.29-8.19(\mathrm{~m}, 2 \mathrm{H}) ;{ }^{13} \mathrm{C}\{1 \mathrm{H}\} \mathbf{N M R}(75 \mathrm{MHz}$, $\left.\mathrm{CDCl}_{3}\right) \delta 155.6(\mathrm{~d}, J=346.3 \mathrm{~Hz}), 152.0,132.7(\mathrm{~d}, J=3.6 \mathrm{~Hz}), 130.4(\mathrm{~d}, J=63.4 \mathrm{~Hz}), 124.3 ;{ }^{19} \mathrm{~F}$ NMR $\left(282 \mathrm{MHz}, \mathrm{CDCl}_{3}\right) \delta+21.0 ;$ MS-EI $(\mathrm{m} / \mathrm{z}) 169.1$

\section{3-fluorobenzoyl fluoride (10j)}<smiles>O=C(F)c1cccc(F)c1</smiles>

3-Fluorobenzoic acid $(1.00 \mathrm{mmol})$ was subjected to the general procedure for conversion of carboxylic acids to acyl fluorides using $\mathrm{SO}_{2} \mathrm{~F}_{2}$. Following the general workup, the residue was filtered through a pad of silica gel using pentanes $(50 \mathrm{~mL})$. The filtrate was concentrated and subjected to a silica gel pipette plug $(1 \mathrm{~cm})$ using pentanes $(8 \mathrm{~mL})$ to remove colored impurities. The product was obtained as a colorless oil (43 $\mathrm{mg}, 31 \%$ yield). The characterization data matched previously reported data. ${ }^{6}$ It has been reported that the product may be unstable to silica gel. ${ }^{4}$

${ }^{1} \mathbf{H}$ NMR $\left(300 \mathrm{MHz}, \mathrm{CDCl}_{3}\right) \delta 7.86(\mathrm{~d}, J=7.7 \mathrm{~Hz}, 1 \mathrm{H}), 7.73(\mathrm{dt}, J=8.7,2.0 \mathrm{~Hz}, 1 \mathrm{H}), 7.53$ (tdd, $J$ $=7.5,5.4,1.5 \mathrm{~Hz}, 1 \mathrm{H}), 7.41$ (tdd, $J=8.3,2.6,1.1 \mathrm{~Hz}, 1 \mathrm{H}) ;{ }^{3} \mathbf{C}\{1 \mathrm{H}\}$ NMR $\left(75 \mathrm{MHz}, \mathrm{CDCl}_{3}\right) \delta 162.8$ (d, $J=249.4 \mathrm{~Hz}), 156.4$ (d, $J=344.4 \mathrm{~Hz}), 131.0(\mathrm{~d}, J=7.8 \mathrm{~Hz}), 127.4(\mathrm{~m}), 127.1$ (dd, $J=62.5$,

${ }^{6}$ Birrell, J. A.; Desrosiers, J.-N.; Jacobsen, E. N. J. Am. Chem. Soc. 2011, 133, 13872-13875. 
$7.8 \mathrm{~Hz}), 122.8(\mathrm{~d}, J=21.3 \mathrm{~Hz}), 118.3(\mathrm{dd}, J=23.7,3.8 \mathrm{~Hz}) ;{ }^{19} \mathrm{~F}$ NMR $\left(282 \mathrm{MHz}, \mathrm{CDCl}_{3}\right) \delta+18.9$ (d, $J=5.0 \mathrm{~Hz}, 1 \mathrm{~F}),-111.0(\mathrm{~m}, 1 \mathrm{~F}) ;$ MS-EI $(\mathrm{m} / \mathrm{z}) 142.1$

In a parallel experiment, 3-fluorobenzoic acid $(1.00 \mathrm{mmol})$ was subjected to the general procedure for the synthesis of carboxylic acid derivatives by one-pot sequential protocol using $\mathrm{N}$ hydroxysuccinimide as the nucleophile. After the reaction was complete, the reaction mixture was diluted with ethyl acetate $(20 \mathrm{~mL})$ and washed with saturated aqueous ammonium chloride $(2 \mathrm{x}$ $10 \mathrm{~mL})$, water $(10 \mathrm{~mL})$, saturated aqueous $\mathrm{NaHCO}_{3}$, and brine $(10 \mathrm{~mL})$. The organic layer was dried over anhydrous $\mathrm{Na}_{2} \mathrm{SO}_{4}$, decanted, and concentrated in vacuo. The crude residue was purified by column chromatography eluting with $5 \%$ methanol in dichloromethane. The product fractions were combined and concentrated in vacuo to afford 2,5-dioxopyrrolidin-1-yl 3fluorobenzoate (S1) as a white solid $(157 \mathrm{mg}, 66 \%$ yield). The characterization data matched previously reported literature data. ${ }^{7}$

${ }^{1} \mathrm{H}$ NMR $\left(300 \mathrm{MHz}, \mathrm{CDCl}_{3}\right) \delta 7.93$ (dt, $\left.J=7.7,1.4 \mathrm{~Hz}, 1 \mathrm{H}\right), 7.81$ (ddd, $J=8.9,2.6,1.6 \mathrm{~Hz}, 1 \mathrm{H}$ ), $7.50(\mathrm{td}, J=8.1,5.4 \mathrm{~Hz}, 1 \mathrm{H}), 7.38$ (tdd, $J=8.3,2.6,1.1 \mathrm{~Hz}, 1 \mathrm{H}), 2.90(\mathrm{~s}, 4 \mathrm{H}) .{ }^{13} \mathrm{C}\{1 \mathrm{H}\}$ NMR $(75$ $\left.\mathrm{MHz}, \mathrm{CDCl}_{3}\right) \delta 169.2,162.6(\mathrm{~d}, J=249.0 \mathrm{~Hz}), 161.0(\mathrm{~d}, J=3.2 \mathrm{~Hz}), 130.8(\mathrm{~d}, J=7.8 \mathrm{~Hz}), 127.2$ (d, $J=7.8 \mathrm{~Hz}), 126.5(\mathrm{~d}, J=3.3 \mathrm{~Hz}), 122.3(\mathrm{~d}, J=21.3 \mathrm{~Hz}), 117.5(\mathrm{~d}, J=23.8 \mathrm{~Hz}), 25.8 ;{ }^{19} \mathrm{~F} \mathrm{NMR}$ $\left(282 \mathrm{MHz}, \mathrm{CDCl}_{3}\right) \delta-111.2(\mathrm{~m})$.

\section{3-cyanobenzoyl fluoride (10k)}<smiles>N#Cc1cccc(C(=O)F)c1</smiles>

3-Cyanobenzoic acid $(1.00 \mathrm{mmol})$ was subjected to the general procedure for conversion of carboxylic acids to acyl fluorides using $\mathrm{SO}_{2} \mathrm{~F}_{2}$. The volatiles were removed in vacuo and the resulting residue was filtered through a pad of silica gel ( $2.5 \mathrm{~cm}$ thick $\times 2 \mathrm{~cm}$ diameter) using $50 \%$ dichloromethane in pentanes $(30 \mathrm{~mL})$. The filtrate was concentrated and subjected to a second filtration. The product was obtained as a white solid ( $76 \mathrm{mg}, 51 \%$ yield). The characterization data matched previously reported data. ${ }^{3}$

${ }^{1} \mathrm{H}$ NMR $\left(300 \mathrm{MHz}, \mathrm{CDCl}_{3}\right) \delta 8.36-8.31(\mathrm{~m}, 1 \mathrm{H}), 8.31-8.23(\mathrm{~m}, 1 \mathrm{H}), 8.03-7.92(\mathrm{~m}, 1 \mathrm{H}), 7.75$ $-7.58(\mathrm{~m}, 1 \mathrm{H}) ;{ }^{13} \mathrm{C}\{1 \mathrm{H}\}$ NMR $\left(75 \mathrm{MHz}, \mathrm{CDCl}_{3}\right) \delta 155.5(\mathrm{~d}, J=345.3 \mathrm{~Hz}), 138.3,135.3(\mathrm{~d}, J=3.8$ $\mathrm{Hz}), 134.9(\mathrm{~d}, J=3.5 \mathrm{~Hz}), 130.4,126.6(\mathrm{~d}, J=64.2 \mathrm{~Hz}), 117.1,114.2 ;{ }^{19} \mathrm{~F} \mathrm{NMR}\left(282 \mathrm{MHz}, \mathrm{CDCl}_{3}\right)$ $\delta+19.0$; MS-El $(\mathrm{m} / \mathrm{z}) 149.1$

${ }^{7}$ Lv, Y.; Sun, K.; Pu, W.; Mao, S.; Li, G.; Niu, J.; Chen, Q.; Wang, T. RSC Adv. 2016, 6, 93486-93490. 


\section{2-iodobenzoyl fluoride (10l)}<smiles>O=C(F)c1ccccc1I</smiles>

2-lodobenzoic acid $(1.01 \mathrm{mmol})$ was subjected to the general procedure for conversion of carboxylic acids to acyl fluorides using $\mathrm{SO}_{2} \mathrm{~F}_{2}$. Following the general workup, the residue was filtered through a pad of silica gel using petroleum ether $(70 \mathrm{~mL})$. The product was obtained as a white solid (100 mg, 40\% yield). The characterization data matched previously reported data. ${ }^{4}$

${ }^{1} \mathrm{H}$ NMR $\left(300 \mathrm{MHz}, \mathrm{CDCl}_{3}\right) \delta 8.18-8.08(\mathrm{~m}, 1 \mathrm{H}), 8.07-7.97(\mathrm{~m}, 1 \mathrm{H}), 7.57-7.44(\mathrm{~m}, 1 \mathrm{H}), 7.37$ - $7.23(\mathrm{~m}, 1 \mathrm{H}) ;{ }^{13} \mathbf{C}\{\mathbf{1 H}\} \mathbf{N M R}\left(75 \mathrm{MHz}, \mathrm{CDCl}_{3}\right) \delta 155.4(\mathrm{~d}, J=345.0 \mathrm{~Hz}), 142.8(\mathrm{~d}, J=3.7 \mathrm{~Hz})$, 135.3, $133.6(\mathrm{~d}, J=2.1 \mathrm{~Hz}), 128.6(\mathrm{~d}, J=60.9 \mathrm{~Hz}), 128.5,97.2(\mathrm{~d}, J=5.9 \mathrm{~Hz}) ;{ }^{19} \mathrm{~F}$ NMR (282 $\left.\mathrm{MHz}, \mathrm{CDCl}_{3}\right) \delta+28.3 ; \mathrm{MS}-\mathrm{El}(\mathrm{m} / \mathrm{z}) 250.0$

\section{nicotinoyl fluoride $(10 \mathrm{~m})$}<smiles>O=C(F)c1cccnc1</smiles>

Nicotinic acid $(0.30 \mathrm{mmol})$ was subjected to the general procedure for conversion of carboxylic acids to acyl fluorides using $\mathrm{SO}_{2} \mathrm{~F}_{2}$. The reaction mixture was analyzed after 2 hours using quantitative ${ }^{19} \mathrm{~F}$ NMR spectroscopy to observe an $86 \%$ yield of $10 \mathrm{~m}$. The acyl fluoride was not isolated due to its instability. ${ }^{4}$

${ }^{19} \mathrm{~F}$ NMR $\left(282 \mathrm{MHz}, \mathrm{CDCl}_{3}\right) \delta+20.0 ;$ MS-EI $(\mathrm{m} / \mathrm{z}) 125.0$

In a parallel experiment, nicotinic acid $(1.01 \mathrm{mmol})$ was subjected to the general procedure for the synthesis of carboxylic acid derivatives by one-pot sequential protocol using $N$ hydroxysuccinimide as the nucleophile. Note: The formation of acyl fluoride proceeded for 2 hours before the reaction was sparged with $\mathrm{N}_{2}$ gas and then the nucleophile was added. After the reaction was complete, the reaction mixture was diluted with ethyl acetate $(20 \mathrm{~mL})$ and washed with water $(4 \times 20 \mathrm{~mL})$. The aqueous layer was then back extracted with ethyl acetate $(10 \mathrm{~mL})$ The combined organic layers were washed with brine $(20 \mathrm{~mL})$, dried over anhydrous $\mathrm{Na}_{2} \mathrm{SO}_{4}$ then decanted and concentrated in vacuo. The residue was subjected to a silica gel plug (Davisil 633 silica, $2 \mathrm{~cm}$ thick $\times 2 \mathrm{~cm}$ diameter) using $50 \%$ ethyl acetate in hexanes (55 mL). The filtrate was concentrated in vacuo to afford 2,5-dioxopyrrolidin-1-yl nicotinate (S2) as a white solid (148 mg, $66 \%$ yield). The characterization data matched previously reported data. ${ }^{8}$

8 De Almeida, A. M.; Andersen, T. L.; Lindhardt, A. T.; De Almeida, M. V.; Skrydstrup, T. J. Org. Chem. 2015, 80, 1920-1928. 
${ }^{1} \mathrm{H}$ NMR $\left(300 \mathrm{MHz}, \mathrm{CDCl}_{3}\right) \delta 9.33(\mathrm{~d}, J=2.2 \mathrm{~Hz}, 1 \mathrm{H}), 8.90(\mathrm{dd}, J=4.9,1.7 \mathrm{~Hz}, 1 \mathrm{H}), 8.40(\mathrm{dd}, J$ $=8.1,1.8 \mathrm{~Hz}, 1 \mathrm{H}), 7.49(\mathrm{dd}, J=8.1,4.9 \mathrm{~Hz}, 1 \mathrm{H}), 2.92(\mathrm{~s}, 4 \mathrm{H}) ;{ }^{13} \mathbf{C}\{1 \mathrm{H}\} \mathbf{N M R}\left(75 \mathrm{MHz}, \mathrm{CDCl}_{3}\right) \delta$ $169.0,160.9,155.3,151.5,138.0,123.8,121.8,25.8$.

isonicotinoyl fluoride (10n)<smiles>O=C(F)c1ccncc1</smiles>

Isonicotinic acid $(0.30 \mathrm{mmol})$ was subjected to the general procedure for conversion of carboxylic acids to acyl fluorides using $\mathrm{SO}_{2} \mathrm{~F}_{2}$. The reaction mixture was analyzed after 2 hours using quantitative ${ }^{19} \mathrm{~F}$ NMR spectroscopy to observe a $52 \%$ yield of $10 \mathrm{n}$. No fluorinated byproducts were observed. The acyl fluoride was not isolated due to its instability. ${ }^{4}$

${ }^{19}$ F NMR $\left(282 \mathrm{MHz}, \mathrm{CDCl}_{3}\right) \delta+20.3 ;$ MS-EI $(\mathrm{m} / \mathrm{z}) 125.0$

In a parallel experiment, isonicotinic acid $(1.01 \mathrm{mmol})$ was subjected to the general procedure for the synthesis of carboxylic acid derivatives by one-pot sequential protocol using $N$ hydroxysuccinimide as the nucleophile. Note: The formation of acyl fluoride proceeded for 2 hours before the reaction was sparged with $\mathrm{N}_{2}$ gas and then the nucleophile was added. After the reaction was complete, the reaction mixture was diluted with ethyl acetate $(20 \mathrm{~mL})$ and washed with water $(4 \times 20 \mathrm{~mL})$. The aqueous layer was then back extracted with ethyl acetate $(10 \mathrm{~mL})$ The combined organic layers were washed with brine $(20 \mathrm{~mL})$, dried over anhydrous $\mathrm{Na}_{2} \mathrm{SO}_{4}$ then decanted and concentrated in vacuo. The residue was subjected to a silica gel plug (Davisil 633 silica, $2 \mathrm{~cm}$ thick $\times 2 \mathrm{~cm}$ diameter) using $70 \%$ ethyl acetate in hexanes $(50 \mathrm{~mL})$. The filtrate was concentrated in vacuo to afford 2,5-dioxopyrrolidin-1-yl isonicotinate (S3) as a beige solid (112 $\mathrm{mg}, 50 \%$ yield). The characterization data matched previously reported data. ${ }^{9}$

${ }^{1} \mathbf{H}$ NMR $\left(300 \mathrm{MHz}, \mathrm{CDCl}_{3}\right) \delta 8.89(\mathrm{~d}, \mathrm{~J}=5.2 \mathrm{~Hz}, 2 \mathrm{H}), 8.13-7.79(\mathrm{~m}, 2 \mathrm{H}), 2.93(\mathrm{~s}, 4 \mathrm{H}) ;{ }^{13} \mathrm{C}\{\mathbf{1} \mathbf{H}\}$ NMR $\left(75 \mathrm{MHz}, \mathrm{CDCl}_{3}\right) \delta$ 168.8, 160.9, 151.0, 132.9, 123.4, 25.8.

furan-3-carbonyl fluoride (100)<smiles>O=C(F)c1ccoc1</smiles>

3-Furoic acid $(0.30 \mathrm{mmol})$ was subjected to the general procedure for conversion of carboxylic acids to acyl fluorides using $\mathrm{SO}_{2} \mathrm{~F}_{2}$. The reaction mixture was analyzed after 2 hours using

9 Wood, M. E.; Bissiriou, S.; Lowe, C.; Norrish, A. M.; Sénéchal, K.; Windeatt, K. M.; Coles, S. J.; Hursthouse, M. B. Org. Biomol. Chem. 2010, 8, 4653-4665. 
quantitative ${ }^{19} \mathrm{~F}$ NMR spectroscopy to observe a $94 \%$ yield of 100 . In a second reaction, a yield of $91 \%$ was observed. The product was not isolated due to its volatility.

${ }^{19}$ F NMR $\left(282 \mathrm{MHz}, \mathrm{CDCl}_{3}\right) \delta+26.9(\mathrm{~d}, J=2.0 \mathrm{~Hz})$; MS-El $(\mathrm{m} / \mathrm{z})$ 114.0.

In a parallel experiment, 3-furoic acid $(1.00 \mathrm{mmol})$ was subjected to the general procedure for the synthesis of carboxylic acid derivatives by one-pot sequential protocol using $N$ hydroxysuccinimide as the nucleophile. Note: The formation of acyl fluoride proceeded for 2 hours before the reaction was sparged with $\mathrm{N}_{2}$ gas and then the nucleophile was added. After the reaction was complete, the reaction mixture was diluted with ethyl acetate $(20 \mathrm{~mL})$ and washed with water $(4 \times 20 \mathrm{~mL})$. The aqueous layer was then back extracted with ethyl acetate $(10 \mathrm{~mL})$ The combined organic layers were washed with brine $(20 \mathrm{~mL})$, dried over anhydrous $\mathrm{Na}_{2} \mathrm{SO}_{4}$ then decanted and concentrated in vacuo. The residue was subjected to flash column chromatography eluting with $50 \%$ ethyl acetate in petroleum ether. The product fractions were combined, concentrated in vacuo to afford 2,5-dioxopyrrolidin-1-yl furan-3-carboxylate (S4) as a white solid (192 mg, 91\% yield). The ${ }^{1} \mathrm{H}$ NMR data matched previously reported data. ${ }^{10}$

${ }^{1} \mathbf{H}$ NMR $\left(300 \mathrm{MHz}, \mathrm{CDCl}_{3}\right) \delta 8.26-8.19(\mathrm{~m}, 1 \mathrm{H}), 7.49(\mathrm{t}, J=1.8 \mathrm{~Hz}, 1 \mathrm{H}), 6.79(\mathrm{~d}, J=2.0 \mathrm{~Hz}$, 1H), $2.82(\mathrm{~s}, 4 \mathrm{H}) ;{ }^{13} \mathrm{C}\{\mathbf{1 H}\}$ NMR $\left(75 \mathrm{MHz}, \mathrm{CDCl}_{3}\right) \delta 169.3,158.1,150.0,144.7,114.0,109.9,25.7$.

\section{thiophene-2-carbonyl fluoride (10p)}<smiles>O=C(F)c1cccs1</smiles>

Thiophene-2-carboxylic acid $(1.00 \mathrm{mmol})$ was subjected to the general procedure for conversion of carboxylic acids to acyl fluorides using $\mathrm{SO}_{2} \mathrm{~F}_{2}$. The reaction was stirred at $40{ }^{\circ} \mathrm{C}$ at 2 hours. Following the general workup, the residue was filtered through a pad of silica gel using pentanes $(70 \mathrm{~mL})$. The product was obtained as a colorless oil (63 $\mathrm{mg}, 49 \%$ yield). The characterization data matched previously reported data. ${ }^{11}$

${ }^{1} \mathrm{H}$ NMR $\left(300 \mathrm{MHz}, \mathrm{CDCl}_{3}\right) \delta 7.95(\mathrm{dd}, J=3.9,1.3 \mathrm{~Hz}, 1 \mathrm{H}), 7.81$ (ddd, $\left.J=5.0,2.2,1.3 \mathrm{~Hz}, 1 \mathrm{H}\right)$, 7.21 (ddd, $J=5.0,3.8,2.0 \mathrm{~Hz}, 1 \mathrm{H}) ;{ }^{13} \mathrm{C}\{1 \mathrm{H}\} \mathbf{N M R}\left(75 \mathrm{MHz}, \mathrm{CDCl}_{3}\right) \delta 152.6(\mathrm{~d}, J=332.2 \mathrm{~Hz})$, $137.8(\mathrm{~d}, J=2.9 \mathrm{~Hz}), 136.8,128.7,127.3(\mathrm{~d}, J=75.5 \mathrm{~Hz}) ;{ }^{19} \mathrm{~F}$ NMR $\left(282 \mathrm{MHz}, \mathrm{CDCl}_{3}\right) \delta+24.0$; MS-EI $(\mathrm{m} / \mathrm{z}) 130.0$

In a parallel experiment, thiophene-2-carboxylic acid $(0.98 \mathrm{mmol})$ was subjected to the general procedure for the synthesis of carboxylic acid derivatives by one-pot sequential protocol using $N$ hydroxysuccinimide as the nucleophile. Note: The formation of acyl fluoride proceeded for 2 hours before the reaction was sparged with $\mathrm{N}_{2}$ gas and then the nucleophile was added. After the reaction was complete, the reaction mixture was diluted with ethyl acetate $(20 \mathrm{~mL})$ and washed

\footnotetext{
${ }^{10}$ Ripka, A.; Shapiro, G.; McRiner, A. J.; Bursavich, M. G. WO142269, 2013.

11 Han, J.; Zhou, W.; Zhang, P. -C.; Wang, H.; Zhang, R.; Wu, H. -H.; Zhang, J. ACS Catal. 2019, 9, 68906895.
} 
with water $(4 \times 20 \mathrm{~mL})$. The aqueous layer was then back extracted with ethyl acetate $(10 \mathrm{~mL})$ The combined organic layers were washed with brine $(20 \mathrm{~mL})$, dried over anhydrous $\mathrm{Na}_{2} \mathrm{SO}_{4}$ then decanted and concentrated in vacuo. The residue was subjected to flash column chromatography eluting with $50 \%$ ethyl acetate in petroleum ether. The product fractions were combined, concentrated in vacuo to afford 2,5-dioxopyrrolidin-1-yl thiophene-2-carboxylate (S5) as a white solid (168 mg, 76\% yield). The characterization data matched previously reported data. ${ }^{12}$

${ }^{1} \mathbf{H}$ NMR $\left(300 \mathrm{MHz}, \mathrm{CDCl}_{3}\right) \delta 8.03(\mathrm{dd}, J=3.9,1.2 \mathrm{~Hz}, 1 \mathrm{H}), 7.77(\mathrm{dd}, J=5.0,1.2 \mathrm{~Hz}, 1 \mathrm{H}), 7.20$ $(\mathrm{dd}, J=5.0,3.9 \mathrm{~Hz}, 1 \mathrm{H}), 2.90(\mathrm{~s}, 4 \mathrm{H}) ;{ }^{13} \mathrm{C}\{1 \mathrm{H}\} \mathbf{N M R}\left(75 \mathrm{MHz}, \mathrm{CDCl}_{3}\right) \delta 169.3,157.5,136.8$, $135.8,128.5,127.0,25.8$.

\section{2,5-dioxopyrrolidin-1-yl 3-phenylpropanoate (11)}<smiles>O=C(CCc1ccccc1)ON1C(=O)CCC1=O</smiles>

Compound 11 was prepared on $1.0 \mathrm{mmol}$ scale following the general procedure for the synthesis of carboxylic acid derivatives by one-pot sequential protocol using $N$-hydroxysuccinimide as the nucleophile. The reaction mixture was diluted with ethyl acetate $(25 \mathrm{~mL})$ and washed with water $(2 \times 10 \mathrm{~mL})$, saturated aqueous ammonium chloride $(2 \times 10 \mathrm{~mL})$ and water $(2 \times 10 \mathrm{~mL})$. The aqueous layer was back extracted with ethyl acetate $(10 \mathrm{~mL})$ and the combined organic layers were washed with brine $(2 \times 10 \mathrm{~mL})$. The organic layer was dried over anhydrous $\mathrm{Na}_{2} \mathrm{SO}_{4}$, decanted, and concentrated in vacuo. The residue was purified by column chromatography eluting with $70 \%$ ethyl acetate in hexanes. The product fractions were combined and then concentrated in vacuo to afford the product as a white solid (214 $\mathrm{mg}, 85 \%$ yield).

${ }^{1} \mathbf{H}$ NMR (300 MHz, $\left.\mathrm{CDCl}_{3}\right) \delta 7.38-7.26(\mathrm{~m}, 2 \mathrm{H}), 7.29-7.18(\mathrm{~m}, 3 \mathrm{H}), 3.12-2.99(\mathrm{~m}, 2 \mathrm{H}), 3.00$ $-2.87(\mathrm{~m}, 2 \mathrm{H}), 2.84(\mathrm{~s}, 4 \mathrm{H}) ;{ }^{13} \mathbf{C}\{\mathbf{1 H}\} \mathbf{N M R}\left(75 \mathrm{MHz}, \mathrm{CDCl}_{3}\right) \delta 169.2,168.1,139.2,128.8,128.4$, 126.9, 32.8, 30.6, 25.7; Melting Point 122-124 ${ }^{\circ} \mathrm{C}$; IR $\left(\mathrm{cm}^{-1}\right)$ (neat): 2947, 1807, 1778, 1735, 1449; HRMS (El) m/z: [M] ${ }^{+}$Calcd for $\mathrm{C}_{13} \mathrm{H}_{13} \mathrm{NO}_{4}$ 247.0845; Found 247.0845.

\section{1,3-dioxoisoindolin-2-yl 3-phenylpropanoate (12)}<smiles>O=C(CCc1ccccc1)ON1C(=O)c2ccccc2C1=O</smiles>

Compound 12 was prepared on $1.0 \mathrm{mmol}$ scale following the general procedure for the synthesis of carboxylic acid derivatives by one-pot sequential protocol using $N$-hydroxyphthalimide as the

12 Barré, A.; Tinţaş, M.-L.; Alix, F.; Gembus, V.; Papamicaël, C.; Levacher, V. J. Org. Chem. 2015, 80, 6537-6544. 
nucleophile. The reaction mixture was diluted with ethyl acetate $(30 \mathrm{~mL})$ and washed with water $(5 \times 20 \mathrm{~mL})$ and brine $(30 \mathrm{~mL})$. The organic layer was dried over anhydrous $\mathrm{Na}_{2} \mathrm{SO}_{4}$, filtered, and then concentrated in vacuo. The crude residue was purified by column chromatography eluting with $20 \%$ ethyl acetate in hexanes. The product fractions were collected and concentrated in vacuo to afford the product as a white solid (213 $\mathrm{mg}, 72 \%)$. The product characterization data matched previously reported literature data. ${ }^{13}$

${ }^{1} \mathbf{H}$ NMR $\left(300 \mathrm{MHz}, \mathrm{CDCl}_{3}\right) \delta 7.93-7.83(\mathrm{~m}, 2 \mathrm{H}), 7.81-7.74(\mathrm{~m}, 2 \mathrm{H}), 7.37-7.28(\mathrm{~m}, 2 \mathrm{H}), 7.28$ $-7.19(\mathrm{~m}, 3 \mathrm{H}), 3.14-3.04(\mathrm{~m}, 2 \mathrm{H}), 3.03-2.93(\mathrm{~m}, 2 \mathrm{H}) ;{ }^{13} \mathbf{C}\{1 \mathrm{H}\}$ NMR $\left(75 \mathrm{MHz}, \mathrm{CDCl}_{3}\right) \delta 169.0$, 162.0, 139.3, 134.9, 129.1, 128.9, 128.4, 126.9, 124.1, 32.9, 30.7.

\section{$N$-methoxy- $N$-methyl-3-phenylpropanamide (13)}<smiles>CON(C)C(=O)CCc1ccccc1</smiles>

Compound 13 was prepared on $1.0 \mathrm{mmol}$ scale following the general procedure for the synthesis of carboxylic acid derivatives by one-pot sequential protocol using an increased amount of DIPEA $(0.71 \mathrm{~mL})$ and $\mathrm{N}, \mathrm{O}$-dimethylhydroxylamine hydrochloride as the nucleophile. The reaction mixture was diluted with ethyl acetate $(25 \mathrm{~mL})$ and washed with saturated aqueous ammonium chloride $(2 \times 10 \mathrm{~mL})$, water $(2 \times 10 \mathrm{~mL})$, and brine $(2 \times 10 \mathrm{~mL})$. The organic layer was dried over anhydrous $\mathrm{Na2SO} 4$, decanted, and concentrated in vacuo. The residue was purified by column chromatography eluting with $30 \%$ ethyl acetate in hexanes. The product fractions were combined and then concentrated in vacuo to afford the product as a clear, pale yellow oil (156 mg, 81\% yield). The product characterization data matched previously reported literature data. ${ }^{14}$

${ }^{1} \mathbf{H}$ NMR $\left(300 \mathrm{MHz}, \mathrm{CDCl}_{3}\right) \delta 7.33-7.15(\mathrm{~m}, 5 \mathrm{H}), 3.60(\mathrm{~s}, 3 \mathrm{H}), 3.17(\mathrm{~s}, 3 \mathrm{H}), 2.96(\mathrm{dd}, J=9.0,6.7$ $\mathrm{Hz}, 2 \mathrm{H}), 2.74(\mathrm{dd}, J=9.0,6.8 \mathrm{~Hz}, 2 \mathrm{H}) ;{ }^{13} \mathbf{C}\{1 \mathrm{H}\}$ NMR $\left(75 \mathrm{MHz} \mathrm{CDCl}_{3}\right) \delta 173.8,141.4,128.5$, $128.5,126.2,61.3,33.9,32.3,30.8$.

\section{S-decyl 3-phenylpropanethioate (14)}<smiles>CCCCCCCCCCSC(=O)CCc1ccccc1</smiles>

Compound 14 was prepared on $1.0 \mathrm{mmol}$ scale following the general procedure for the synthesis of carboxylic acid derivatives by one-pot sequential protocol using 1-decanethiol $(1 \mathrm{mmol})$ as the nucleophile. The reaction mixture was concentrated in vacuo and the residual oil was purified by column chromatography eluting with $5 \%$ ethyl acetate in hexanes. The product fractions were

${ }^{13}$ Sheikh, M. C.; Takagi, S.; Sakai, M.; Mori, T.; Hayashi, N.; Fujie, T.; Ono, S.; Yoshimura, T.; Morita, H. Org. Biomol. Chem. 2011, 9, 1244-1254.

${ }^{14}$ Murphy, J. A.; Commeureuc, A. G. J.; Snaddon, T. N.; McGuire, T. M.; Khan, T. A.; Hisler, K.; Dewis, M. L.; Carling, R. Org. Lett. 2005, 7, 1427-1429. 
combined and then concentrated in vacuo to afford the product as a colorless oil (296 mg, 96\% yield).

${ }^{1} \mathbf{H}$ NMR $\left(300 \mathrm{MHz}, \mathrm{CDCl}_{3}\right) \delta 7.33-7.15(\mathrm{~m}, 5 \mathrm{H}), 3.02-2.93(\mathrm{~m}, 2 \mathrm{H}), 2.91-2.83(\mathrm{~m}, 4 \mathrm{H}), 1.61$ $-1.49(\mathrm{~m}, 2 \mathrm{H}), 1.34-1.22(\mathrm{~m}, 14 \mathrm{H}), 0.93-0.87(\mathrm{~m}, 3 \mathrm{H}) ;{ }^{13} \mathbf{C}\{1 \mathrm{H}\}$ NMR $\left(75 \mathrm{MHz}, \mathrm{CDCl}_{3}\right) \delta 198.9$, 140.3, 128.6, 128.4, 126.4, 45.7, 32.0, 31.6, 29.7, 29.7, 29.6, 29.4, 29.2, 29.0, 28.9, 22.8, 14.2; IR $\left(\mathrm{cm}^{-1}\right)$ (neat): 3029, 2924, 2854, 1689, 1497, 1454, 1045, 971, 742, 697; HRMS (EI) m/z: [M] ${ }^{+}$ Calcd for $\mathrm{C}_{19} \mathrm{H}_{30} \mathrm{OS} 306.2017$; Found 306.2013.

\section{2,5-dioxopyrrolidin-1-yl benzoate (15)}<smiles>O=C(ON1C(=O)CCC1=O)c1ccccc1</smiles>

Compound 15 was prepared on $1.0 \mathrm{mmol}$ scale following the general procedure for the synthesis of carboxylic acid derivatives by one-pot sequential protocol using $\mathrm{N}$-hydroxysuccinimide as the nucleophile. The reaction mixture was diluted with ethyl acetate $(30 \mathrm{~mL})$ and washed with water $(4 \times 20 \mathrm{~mL})$ and then brine $(30 \mathrm{~mL})$. The organic layer was dried over anhydrous $\mathrm{Na}_{2} \mathrm{SO}_{4}$, filtered and concentrated in vacuo. The crude residue was purified by column chromatography eluting with $30-40 \%$ ethyl acetate in hexanes. The product fractions were combined and then concentrated in vacuo to afford the product as a white solid (197 mg, $90 \%$ yield). The product characterization data matched previously reported literature data. ${ }^{15}$

${ }^{1} \mathbf{H}$ NMR $\left(300 \mathrm{MHz}, \mathrm{CDCl}_{3}\right) \delta 8.24-8.07(\mathrm{~m}, 2 \mathrm{H}), 7.79-7.59(\mathrm{~m}, 1 \mathrm{H}), 7.51(\mathrm{t}, J=7.8 \mathrm{~Hz}, 2 \mathrm{H})$, $2.91(\mathrm{~s}, 4 \mathrm{H}) ;{ }^{13} \mathrm{C}\{1 \mathrm{H}\}$ NMR $\left(75 \mathrm{MHz}, \mathrm{CDCl}_{3}\right) \delta 169.4,162.0,135.1,130.7,129.0,125.3,25.8$.

\section{1,3-dioxoisoindolin-2-yl benzoate (16)}<smiles>O=C(ON1C(=O)c2ccccc2C1=O)c1ccccc1</smiles>

Compound 16 was prepared on $1.0 \mathrm{mmol}$ scale following the general procedure for the synthesis of carboxylic acid derivatives by one-pot sequential protocol using $N$-hydroxyphthalimide as the nucleophile. The reaction mixture was diluted with ethyl acetate $(30 \mathrm{~mL})$ and then washed with water $(4 \times 20 \mathrm{~mL})$ and brine $(30 \mathrm{~mL})$. The organic layer was dried over anhydrous $\mathrm{Na}_{2} \mathrm{SO}_{4}$, filtered and concentrated in vacuo. The crude solid was triturated three times using dichloromethane (3 $\mathrm{mL}$ ) and then dried in vacuo to afford the product as a white solid (242 $\mathrm{mg}, 91 \%$ yield). The product characterization data matched previously reported literature data. ${ }^{7}$

15 Naiwei, W.; Renhua, L.; Qing, X.; Xinmiao, L. Chem. Lett. 2006, 35, 566-567. 
${ }^{1} \mathbf{H}$ NMR $\left(300 \mathrm{MHz}, \mathrm{CDCl}_{3}\right) \delta 8.28-8.13(\mathrm{~m}, 2 \mathrm{H}), 7.93(\mathrm{dd}, J=5.5,3.1 \mathrm{~Hz}, 2 \mathrm{H}), 7.81$ (dd, $J=5.5$, $3.1 \mathrm{~Hz}, 2 \mathrm{H}), 7.76-7.64(\mathrm{~m}, 1 \mathrm{H}), 7.54(\mathrm{dd}, J=8.5,7.1 \mathrm{~Hz}, 2 \mathrm{H}) ;{ }^{13} \mathbf{C}\{1 \mathrm{H}\} \mathbf{N M R}\left(75 \mathrm{MHz}, \mathrm{CDCl}_{3}\right) \delta$ 162.9, 162.2, 135.0, 134.9, 130.8, 129.2, 129.0, 125.4, 124.2.

\section{$N$-methoxy- $N$-methylbenzamide (17)}<smiles>CON(C)C(=O)c1ccccc1</smiles>

Compound 17 was prepared on $1.0 \mathrm{mmol}$ scale following the general procedure for the synthesis of carboxylic acid derivatives by one-pot sequential protocol using $\mathrm{N}, \mathrm{O}$-dimethylhydroxylamine hydrochloride as the nucleophile. $\mathrm{N}, \mathrm{O}$-dimethylhydroxylamine was added as a solution of the $\mathrm{HCl}$ salt and DIPEA $(0.30 \mathrm{~mL})$ in ACN $(1.0 \mathrm{~mL})$. The reaction mixture was diluted with ethyl acetate $(30 \mathrm{~mL})$ and washed with aqueous $\mathrm{HCl}(0.2 \mathrm{M}, 5 \times 20 \mathrm{~mL})$ and then brine $(30 \mathrm{~mL})$. The organic layer was dried over anhydrous $\mathrm{Na}_{2} \mathrm{SO}_{4}$, filtered, and concentrated in vacuo. The crude residue was purified by column chromatography eluting with $50 \%$ ethyl acetate in hexanes. The product fractions were combined and then concentrated in vacuo to afford the product as a colorless oil (141 mg, 85\% yield). The product characterization data matched previously reported literature data. ${ }^{14}$

${ }^{1} \mathrm{H}$ NMR (300 MHz, $\left.\mathrm{CDCl}_{3}\right)$ ठ $7.70-7.62(\mathrm{~m}, 2 \mathrm{H}), 7.47-7.32(\mathrm{~m}, 3 \mathrm{H}), 3.55(\mathrm{~s}, 3 \mathrm{H}), 3.36(\mathrm{~s}, 3 \mathrm{H})$; ${ }^{13} \mathrm{C}\{1 \mathrm{H}\}$ NMR $\left(75 \mathrm{MHz}, \mathrm{CDCl}_{3}\right) \delta 170.1,134.3,130.7,128.3,128.1,61.2,33.9$.

\section{S-decyl benzothioate (18)}<smiles>CCCCCCCCCCSC(=O)c1ccccc1</smiles>

Compound 18 was prepared on $1.0 \mathrm{mmol}$ scale following the general procedure for the synthesis of carboxylic acid derivatives by one-pot sequential protocol using 1-decanethiol $(1 \mathrm{mmol})$ as the nucleophile. The reaction mixture was concentrated in vacuo and the crude residue was purified by column chromatography eluting with $0-5 \%$ ethyl acetate in hexanes. The product fractions were combined and then concentrated in vacuo to afford the product as a colorless oil (260 mg, $93 \%$ yield).

${ }^{1} \mathrm{H}$ NMR $\left(300 \mathrm{MHz}, \mathrm{CDCl}_{3}\right) \delta 8.01-7.86(\mathrm{~m}, 2 \mathrm{H}), 7.62-7.51(\mathrm{~m}, 1 \mathrm{H}), 7.44(\mathrm{dd}, J=8.3,6.8 \mathrm{~Hz}$, $2 \mathrm{H}), 3.07(\mathrm{t}, J=7.3 \mathrm{~Hz}, 2 \mathrm{H}), 1.85-1.46(\mathrm{~m}, 2 \mathrm{H}), 1.48-1.37(\mathrm{~m}, 2 \mathrm{H}), 1.28(\mathrm{~d}, J=5.6 \mathrm{~Hz}, 12 \mathrm{H})$, $1.03-0.68(\mathrm{~m}, 3 \mathrm{H}) ;{ }^{13} \mathrm{C}\{1 \mathrm{H}\}$ NMR $\left(75 \mathrm{MHz}, \mathrm{CDCl}_{3}\right) \delta 192.3,137.4,133.3,128.7,127.3,32.0$, 29.7, 29.7, 29.6, 29.4, 29.3, 29.2, 29.1, 22.8, 14.2; IR (cm ${ }^{-1}$ ) (neat): 3063, 2923, 2853, 1663, 1597, 686; HRMS (El) $\mathrm{m} / \mathrm{z}$ : [M] ${ }^{+}$Calcd for $\mathrm{C}_{17} \mathrm{H}_{26} \mathrm{OS}$ 278.1704; Found 278.1714. 
<smiles>O=C(CC(c1ccccc1)c1ccccc1)ON1C(=O)CCC1=O</smiles>

Compound $\mathbf{S 6}$ was prepared on $1.0 \mathrm{mmol}$ scale following the general procedure for the synthesis of carboxylic acid derivatives by one-pot sequential protocol using $N$-hydroxysuccinimide as the nucleophile. The reaction mixture was diluted with ethyl acetate $(30 \mathrm{~mL})$ and washed with water $(4 \times 20 \mathrm{~mL})$ and brine $(30 \mathrm{~mL})$. The organic layer was dried over anhydrous $\mathrm{Na}_{2} \mathrm{SO}_{4}$, filtered, and concentrated in vacuo. The crude residue was purified by column chromatography eluting with $30-50 \%$ ethyl acetate in hexanes. The product fractions were combined and then concentrated in vacuo to afford the product as a white solid ( $284 \mathrm{mg}, 88 \%$ yield).

${ }^{1} \mathbf{H}$ NMR $\left(300 \mathrm{MHz}, \mathrm{CDCl}_{3}\right) \delta 7.40-7.08(\mathrm{~m}, 10 \mathrm{H}), 4.60(\mathrm{t}, J=7.9 \mathrm{~Hz}, 1 \mathrm{H}), 3.36(\mathrm{~d}, J=7.9 \mathrm{~Hz}$, 2H), $2.77(\mathrm{~s}, 4 \mathrm{H}) ;{ }^{13} \mathbf{C}\{\mathbf{1 H}\} \mathbf{N M R}\left(75 \mathrm{MHz}, \mathrm{CDCl}_{3}\right) \delta$ 169.0, 167.1, 142.4, 128.9, 127.7, 127.0, 46.7, 37.4, 25.6; Melting Point 103-105 ${ }^{\circ} \mathrm{C}$; IR $\left(\mathrm{cm}^{-1}\right)$ (neat): 3060, 1814, 1785, 1732, 1599, 1495; HRMS (ESI) $\mathrm{m} / \mathrm{z}$ : $[\mathrm{M}+\mathrm{Na}]^{+}$Calcd for $\mathrm{C}_{19} \mathrm{H}_{17} \mathrm{NO}_{4} \mathrm{Na} 346.1055$; Found 346.1056.

\section{1,3-dioxoisoindolin-2-yl 3,3-diphenylpropanoate (S7)}<smiles>O=C(CC(c1ccccc1)c1ccccc1)ON1C(=O)c2ccccc2C1=O</smiles>

Compound $\mathbf{S 7}$ was prepared on $1.0 \mathrm{mmol}$ scale following the general procedure for the synthesis of carboxylic acid derivatives by one-pot sequential protocol using $N$-hydroxyphthalimide as the nucleophile. The reaction mixture was diluted with ethyl acetate $(50 \mathrm{~mL})$ and washed with water $(5 \times 20 \mathrm{~mL})$ and then brine $(30 \mathrm{~mL})$. The organic layer was dried over anhydrous $\mathrm{Na}_{2} \mathrm{SO}_{4}$, filtered and concentrated in vacuo to afford the product as a white solid (336 mg, 91\% yield).

${ }^{1} \mathrm{H}$ NMR $\left(300 \mathrm{MHz}, \mathrm{CDCl}_{3}\right) \delta 7.84(\mathrm{dd}, J=5.5,3.1 \mathrm{~Hz}, 2 \mathrm{H}), 7.75$ (dd, $\left.J=5.5,3.1 \mathrm{~Hz}, 2 \mathrm{H}\right), 7.38-$ $7.16(\mathrm{~m}, 10 \mathrm{H}), 4.65(\mathrm{t}, J=7.9 \mathrm{~Hz}, 1 \mathrm{H}), 3.42(\mathrm{~d}, J=7.9 \mathrm{~Hz}, 2 \mathrm{H}) ;{ }^{13} \mathbf{C}\{\mathbf{1 H}\} \mathbf{N M R}\left(75 \mathrm{MHz}, \mathrm{CDCl}_{3}\right) \delta$ 168.0, 161.9, 142.5, 134.8, 129.0, 128.9, 127.8, 127.1, 124.1, 46.8, 37.6; Melting Point 181-183 ${ }^{\circ} \mathrm{C}$; IR $\left(\mathrm{cm}^{-1}\right)$ (neat): 3060, 1818, 1785, 1738, 1492; HRMS (ESI) $\mathrm{m} / \mathrm{z}$ : $[\mathrm{M}+\mathrm{Na}]^{+}$Calcd for $\mathrm{C}_{23} \mathrm{H}_{17} \mathrm{NO}_{4} \mathrm{Na}$ 394.1055; Found 394.1053. 


\section{N-methoxy-N-methyl-3,3-diphenylpropanamide (S8)}<smiles>CON(C)C(=O)CC(c1ccccc1)c1ccccc1</smiles>

Compound S8 was prepared on $1.0 \mathrm{mmol}$ scale following the general procedure for the synthesis of carboxylic acid derivatives by one-pot sequential protocol using an increased amount of DIPEA $(0.80 \mathrm{~mL})$ and $\mathrm{N}, \mathrm{O}$-dimethylhydroxylamine hydrochloride as the nucleophile. The reaction mixture was diluted with ethyl acetate $(30 \mathrm{~mL})$ and washed with aqueous $\mathrm{HCl}(0.2 \mathrm{M}, 5 \times 20 \mathrm{~mL})$ and then brine $(30 \mathrm{~mL})$. The organic layer was dried over anhydrous $\mathrm{Na}_{2} \mathrm{SO}_{4}$, filtered, and concentrated in vacuo. The crude residue was purified by column chromatography eluting with $10-15 \%$ ethyl acetate in hexanes. The product fractions were combined and then concentrated in vacuo to afford the product as a colorless oil (236 $\mathrm{mg}, 88 \%$ yield).

${ }^{1} \mathrm{H}$ NMR $\left(300 \mathrm{MHz}, \mathrm{CDCl}_{3}\right) \delta 7.32-7.14(\mathrm{~m}, 10 \mathrm{H}), 4.71(\mathrm{t}, J=7.7 \mathrm{~Hz}, 1 \mathrm{H}), 3.56(\mathrm{~s}, 3 \mathrm{H}), 3.20(\mathrm{~d}$, $J=7.7 \mathrm{~Hz}, 2 \mathrm{H}), 3.11(\mathrm{~s}, 3 \mathrm{H}) ;{ }^{13} \mathbf{C}\{\mathbf{1 H}\} \mathbf{N M R}\left(75 \mathrm{MHz}, \mathrm{CDCl}_{3}\right) \delta 172.5,144.3,128.6,128.0,126.4$, 61.4, 46.4, 38.0, 32.2; IR (cm $\left.{ }^{-1}\right)$ (neat): 3060, 3027, 2967, 2937, 1657, 1599, 1494; HRMS (EI) $\mathrm{m} / \mathrm{z}$ : $[\mathrm{M}]^{+}$Calcd for $\mathrm{C}_{17} \mathrm{H}_{19} \mathrm{NO}_{2}$ 269.1416; Found 269.1417.

\section{S-decyl 3,3-diphenylpropanethioate (S9)}<smiles>CCCCCCCCCCSC(=O)CC(c1ccccc1)c1ccccc1</smiles>

Compound $\mathbf{S 9}$ was prepared on $1.0 \mathrm{mmol}$ scale following the general procedure for the synthesis of carboxylic acid derivatives by one-pot sequential protocol using 1-decanethiol $(1 \mathrm{mmol})$ as the nucleophile. The reaction mixture was concentrated in vacuo and the residue was purified by column chromatography eluting with $0-8 \%$ ethyl acetate in hexanes. The product fractions were combined and then concentrated in vacuo to afford the product as a colorless oil $(306 \mathrm{mg}, 80 \%$ yield).

${ }^{1} \mathrm{H}$ NMR $\left(300 \mathrm{MHz}, \mathrm{CDCl}_{3}\right) \delta 7.34-7.07(\mathrm{~m}, 10 \mathrm{H}), 4.64(\mathrm{t}, J=7.9 \mathrm{~Hz}, 1 \mathrm{H}), 3.29(\mathrm{~d}, J=7.9 \mathrm{~Hz}$, $2 \mathrm{H}), 2.79(\mathrm{t}, J=7.2 \mathrm{~Hz}, 2 \mathrm{H}), 1.45(\mathrm{~m}, 2 \mathrm{H}), 1.32-1.18(\mathrm{~m}, 14 \mathrm{H}), 0.89(\mathrm{t}, J=6.7 \mathrm{~Hz}, 3 \mathrm{H}) ;{ }^{13} \mathrm{C}\{1 \mathrm{H}\}$ NMR $\left(75 \mathrm{MHz}, \mathrm{CDCl}_{3}\right) \delta 197.8,143.3,128.8,127.9,126.7,50.0,47.4,32.0,29.7,29.6,29.5$, 29.4, 29.2, 29.1, 28.8, 22.8, 14.3; IR ( $\left.\mathrm{cm}^{-1}\right)$ (neat): 3029, 2923, 2853, 1687, 1600, 1494; HRMS (EI) $\mathrm{m} / \mathrm{z}:[\mathrm{M}]^{+}$Calcd for $\mathrm{C}_{25} \mathrm{H}_{34} \mathrm{OS} 382.2330$; Found 382.2332. 


\section{Procedure for the single-addition reactions}

Scheme S5 - Single-addition reactions where the nucleophile is added before $\mathrm{SO}_{2} \mathrm{~F}_{2}$

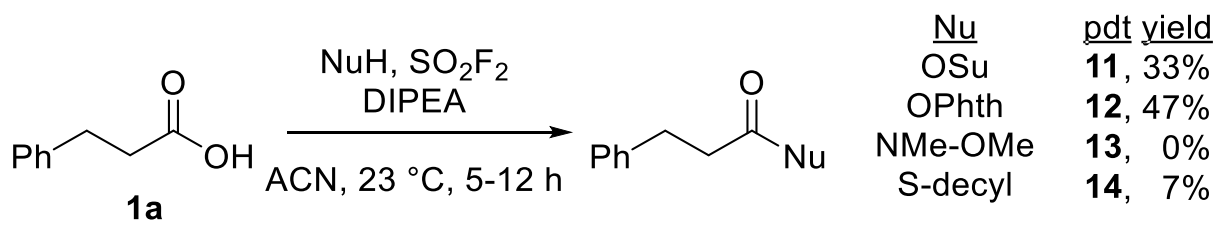

Two $20 \mathrm{~mL}$ vials, equipped with magnetic stir-bars, were capped with septum-fitted vial caps and connected by polyethylene tubing. Vial A was charged with SDI (5.70 mmol, 5.70 equiv) and anhydrous KF (15.6 mmol, 15.6 equiv). To vial B was added carboxylic acid 1a $(1.00 \mathrm{mmol}, 1$ equiv), nucleophile (2 mmol, 2 equiv), dry ACN (3.30 mL), and DIPEA (3.00 mmol, 3.00 equiv). The reaction vial $(B)$ was stirred at $23^{\circ} \mathrm{C}$, and then the polyethylene tube in vial $\mathrm{B}$ was immersed into the solution. To vial $A$ was added TFA $(5.0 \mathrm{~mL})$ in one portion. Vigorous bubbling of $\mathrm{SO}_{2} \mathrm{~F}_{2}$ and fuming were observed in vial $\mathrm{B}$ for 2-3 minutes and when the bubbling subsided, vial $\mathrm{B}$ was vented via a needle for approximately 1 minute (this triggered more bubbling of $\mathrm{SO}_{2} \mathrm{~F}_{2}$ through the solution). The polyethylene tubing and needle were removed and the mixture in vial $\mathrm{B}$ was stirred for $5-12$ hours at $23^{\circ} \mathrm{C}$.

workup: For reactions forming the products 11, 12, and 13, the reaction mixture was diluted with ethyl acetate $(30 \mathrm{~mL})$ and washed with water $(4 \times 20 \mathrm{~mL})$ and brine $(30 \mathrm{~mL})$. The organic layer was dried over anhydrous $\mathrm{Na}_{2} \mathrm{SO}_{4}$, filtered, and concentrated in vacuo. The crude residue was purified by column chromatography eluting with ethyl acetate in hexanes $(10-20 \%$ for $11 ; 20-$ $35 \%$ for $12 ; 20-50 \%$ for 13$)$. The product fractions were combined and concentrated in vacuo to afford the products in $0-47 \%$ yields.

For product 14, the reaction mixture was concentrated in vacuo and the crude residue was purified by column chromatography eluting with $5 \%$ ethyl acetate in hexanes. The product fractions were combined and concentration in vacuo to afford the product as an oil ( $21 \mathrm{mg}, 7 \%$ yield). 
10a $\left({ }^{1} \mathrm{H} \mathrm{NMR}\right.$ in $\left.\mathrm{CDCl}_{3}\right)(300 \mathrm{MHz})$

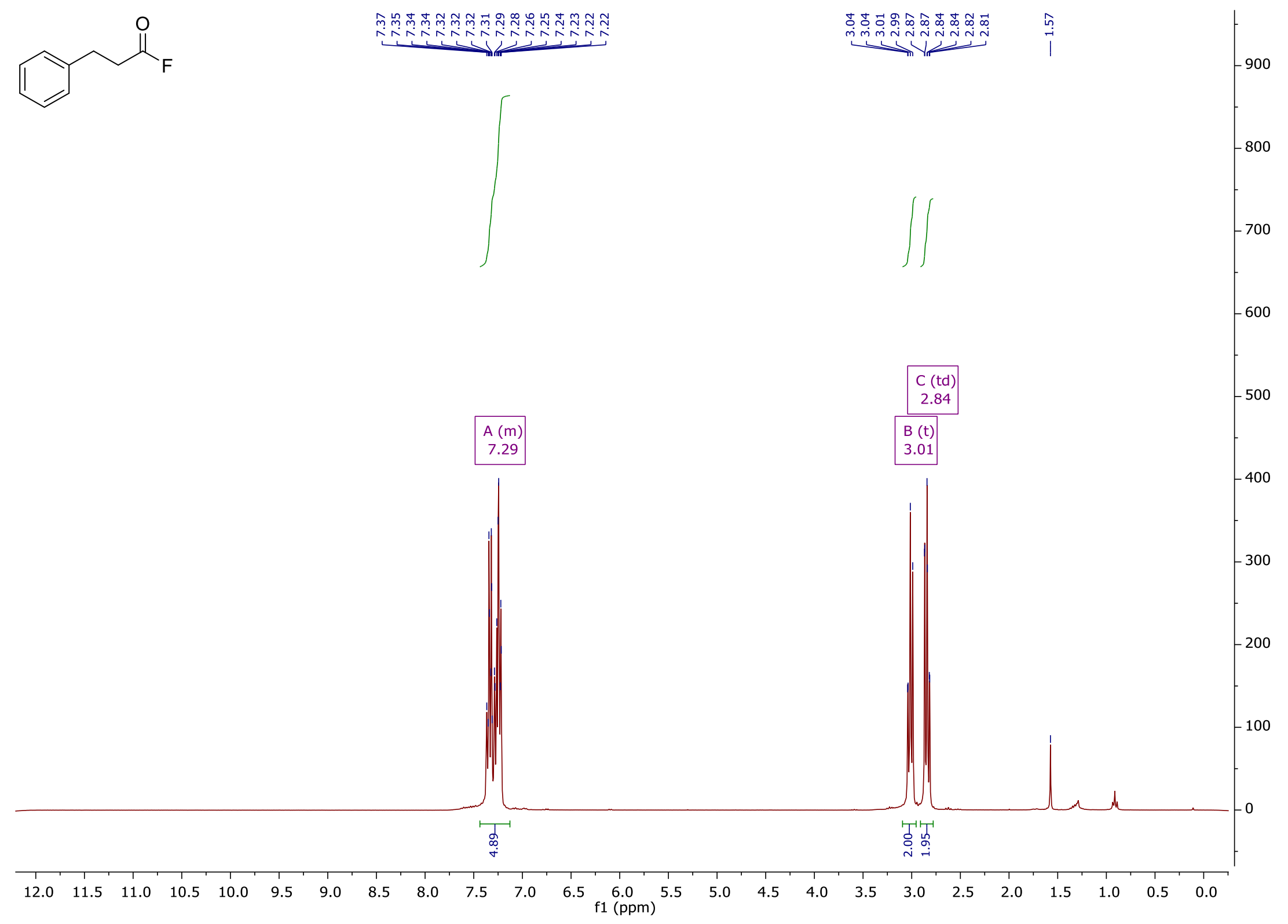


10a $\left({ }^{13} \mathrm{C} \mathrm{NMR}\right.$ in $\left.\mathrm{CDCl}_{3}\right)(75 \mathrm{MHz})$

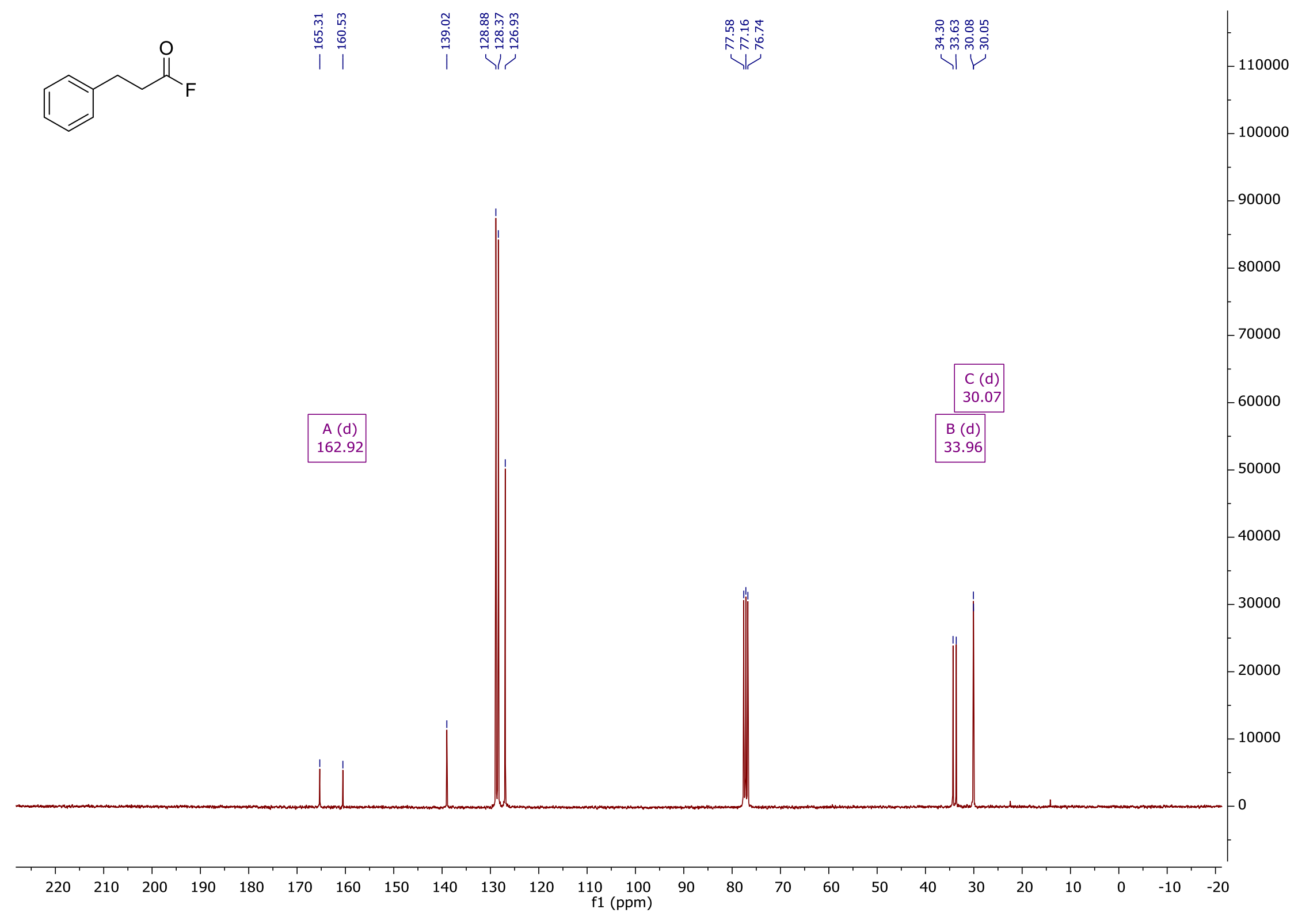




\section{0a ( ${ }^{19} \mathrm{~F}$ NMR in $\left.\mathrm{CDCl}_{3}\right)(282 \mathrm{MHz})$}

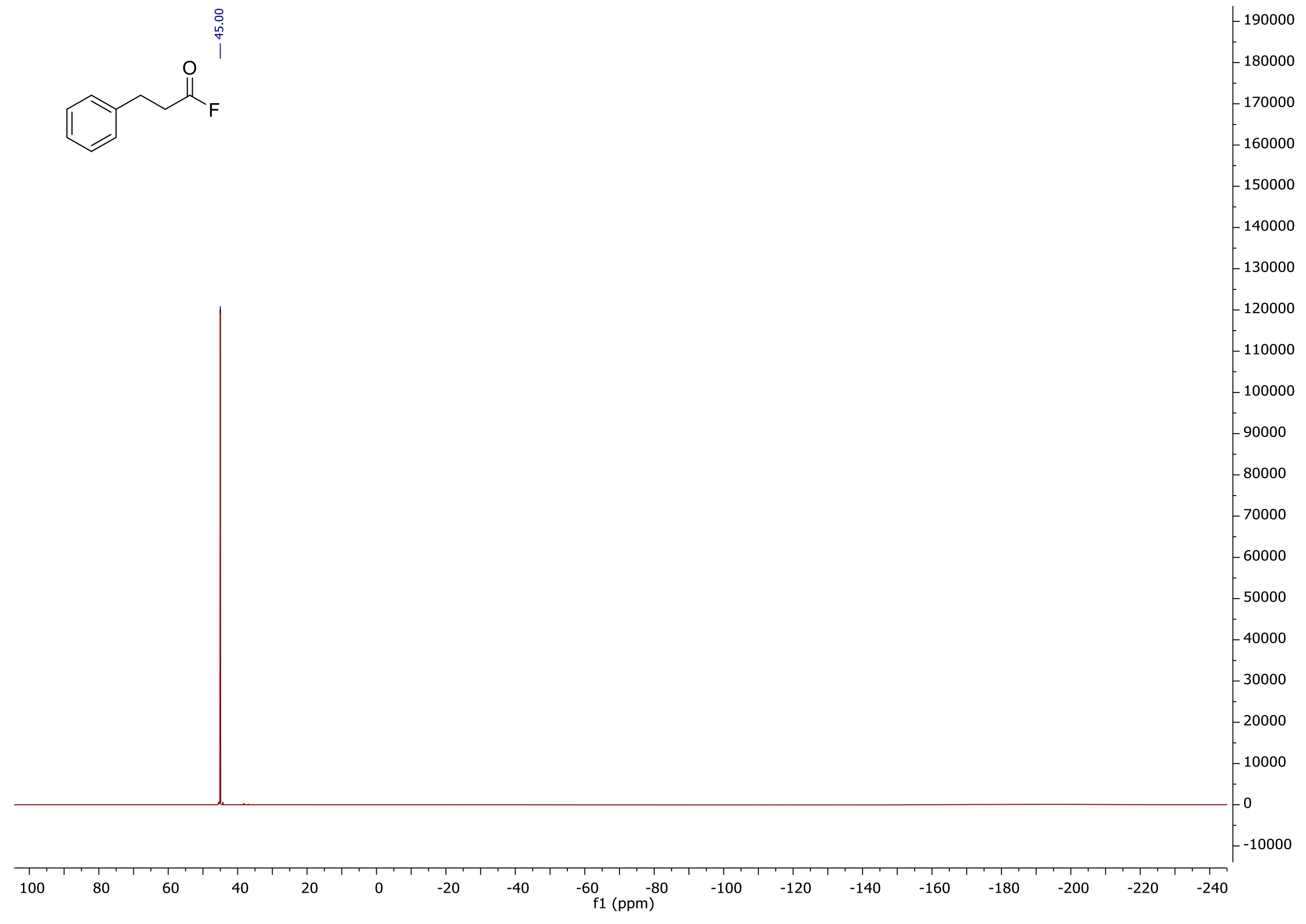


10b $\left({ }^{1} \mathrm{H}\right.$ NMR in $\left.\mathrm{CDCl}_{3}\right)(300 \mathrm{MHz})$

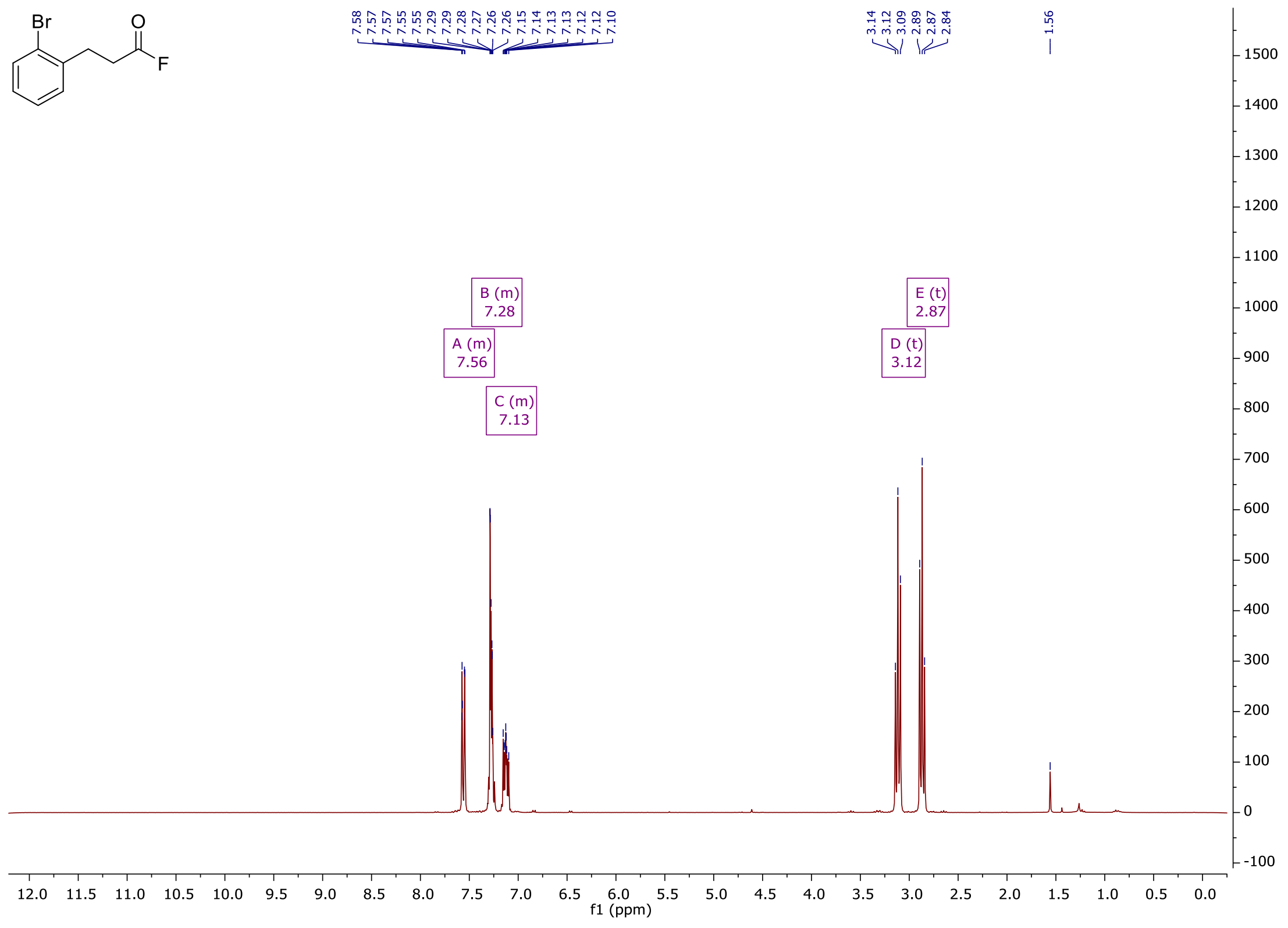


10b $\left({ }^{13} \mathrm{C}\right.$ NMR in $\left.\mathrm{CDCl}_{3}\right)(75 \mathrm{MHz})$

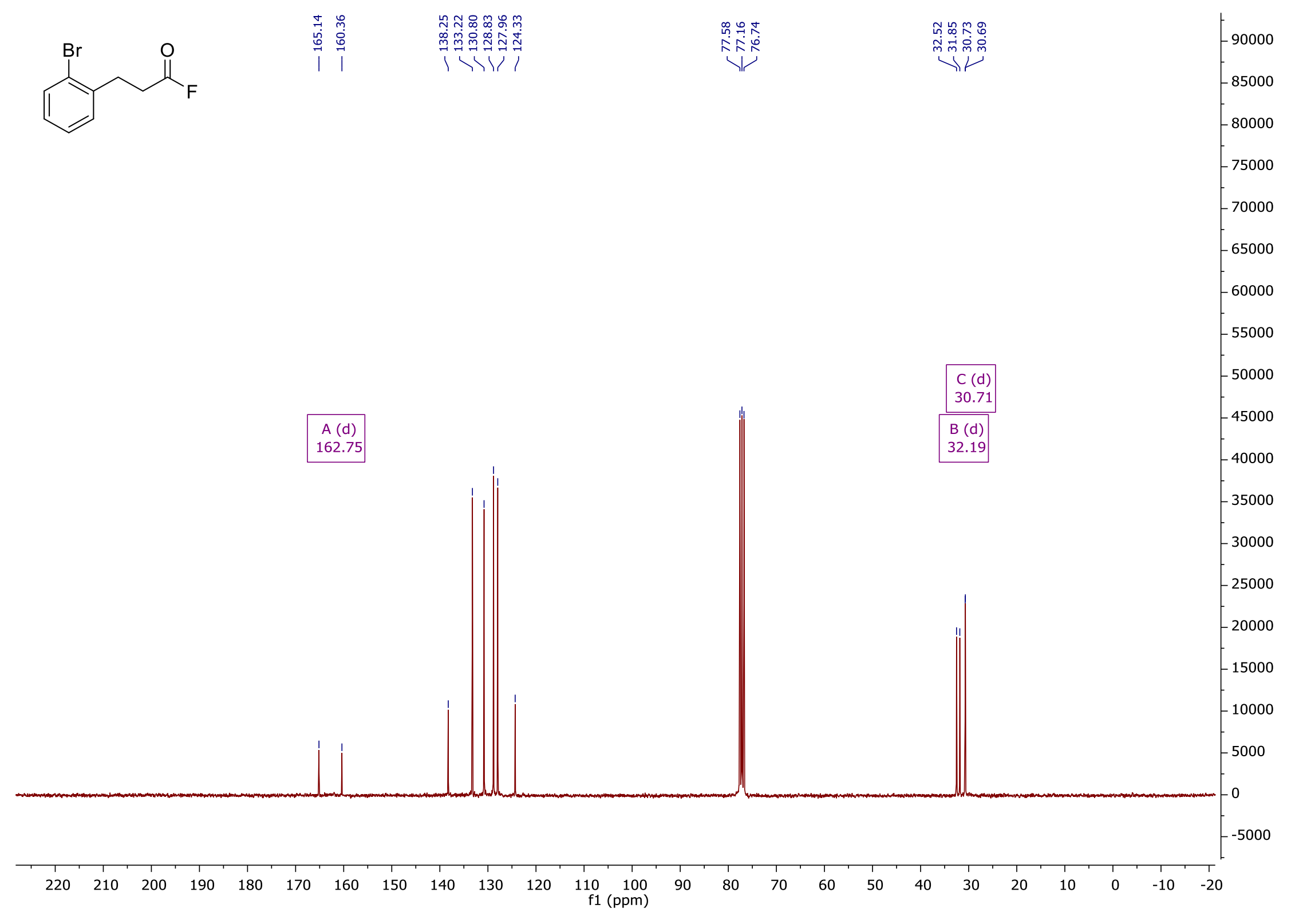


$10 \mathrm{~b}\left({ }^{19} \mathrm{~F} \mathrm{NMR}\right.$ in $\left.\mathrm{CDCl}_{3}\right)(282 \mathrm{MHz})$

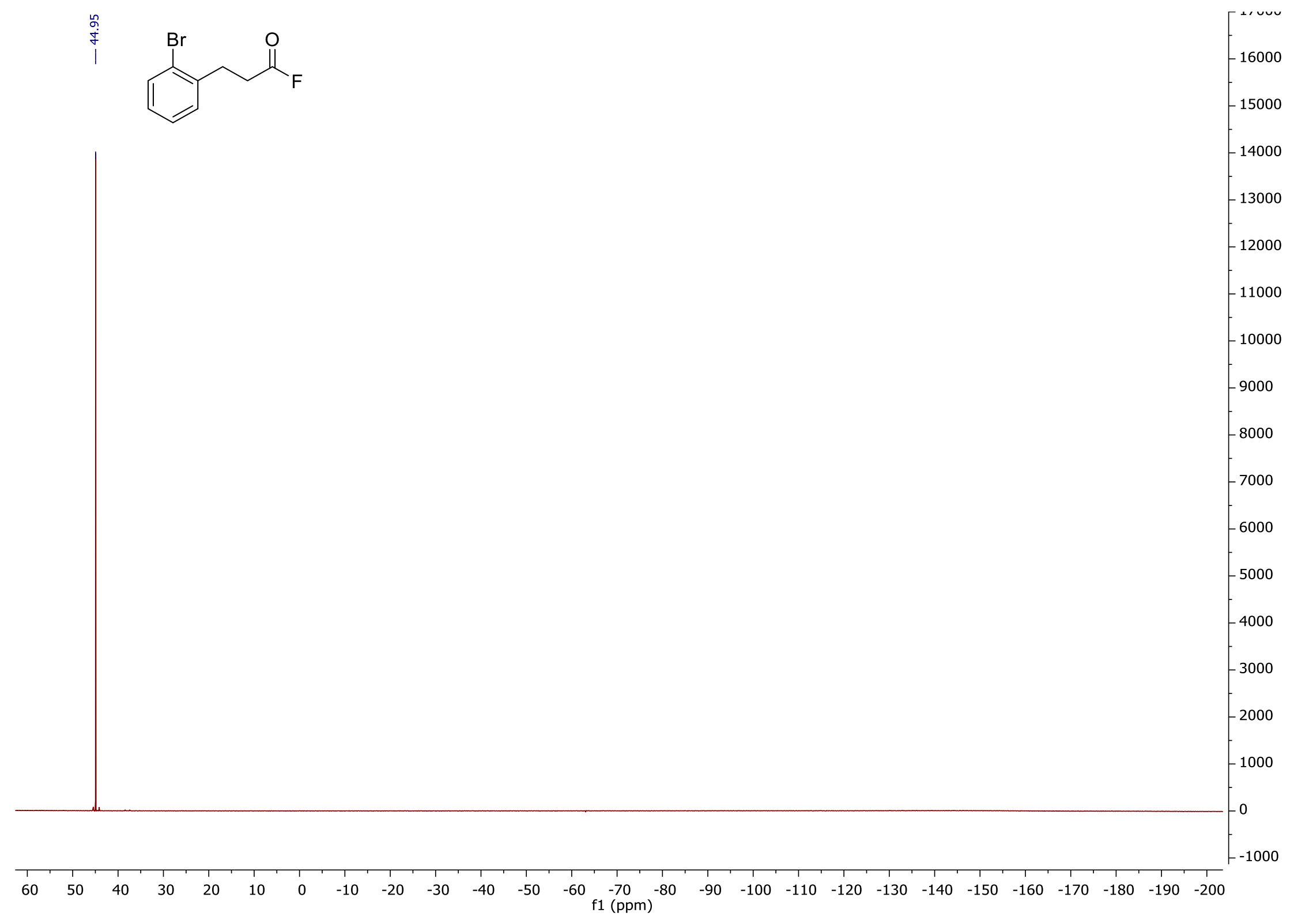


10c ( ${ }^{1} \mathrm{H} \mathrm{NMR}$ in $\left.\mathrm{CDCl}_{3}\right)(300 \mathrm{MHz})$

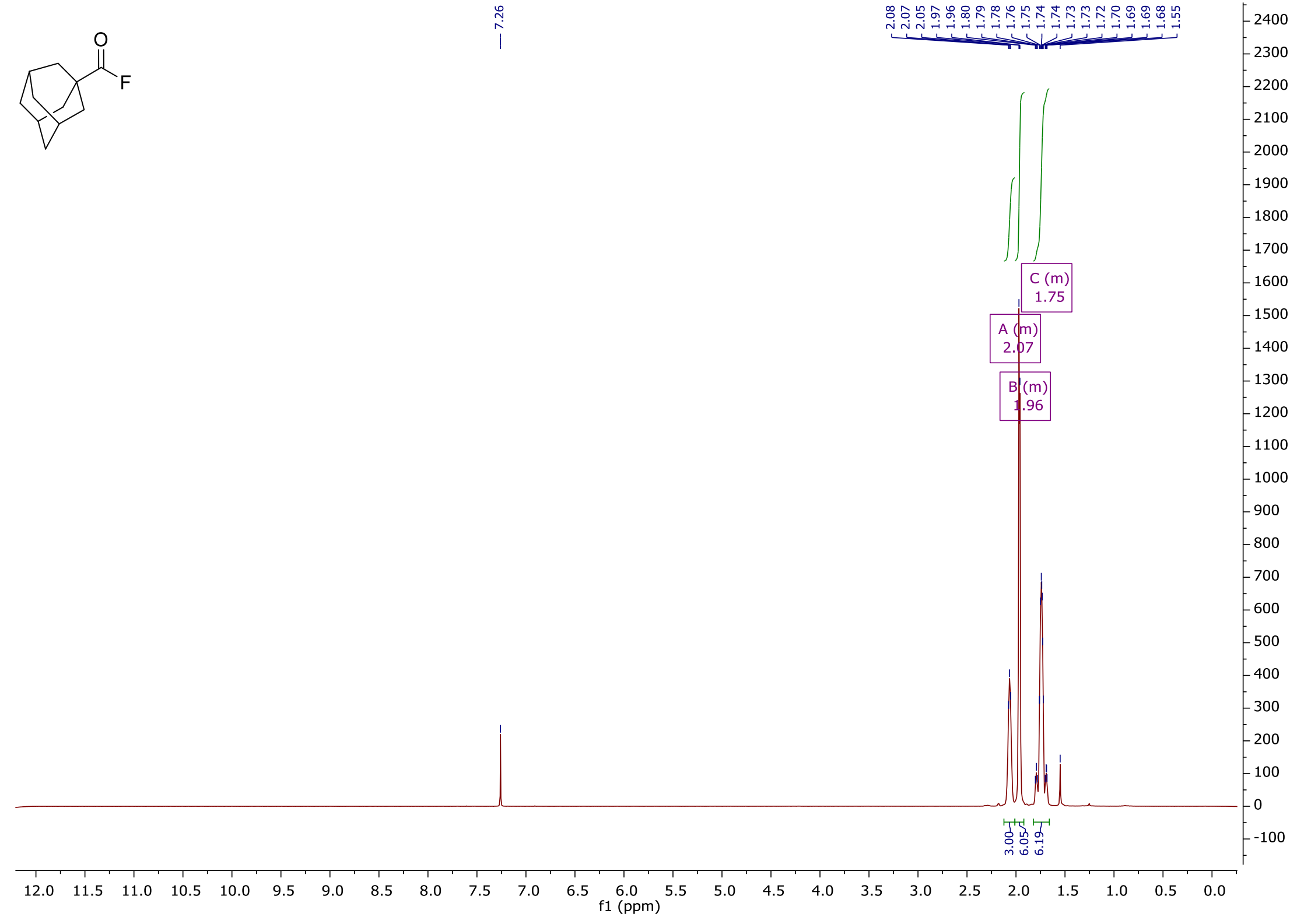


10c $\left({ }^{13} \mathrm{C}\right.$ NMR in $\left.\mathrm{CDCl}_{3}\right)(75 \mathrm{MHz})$

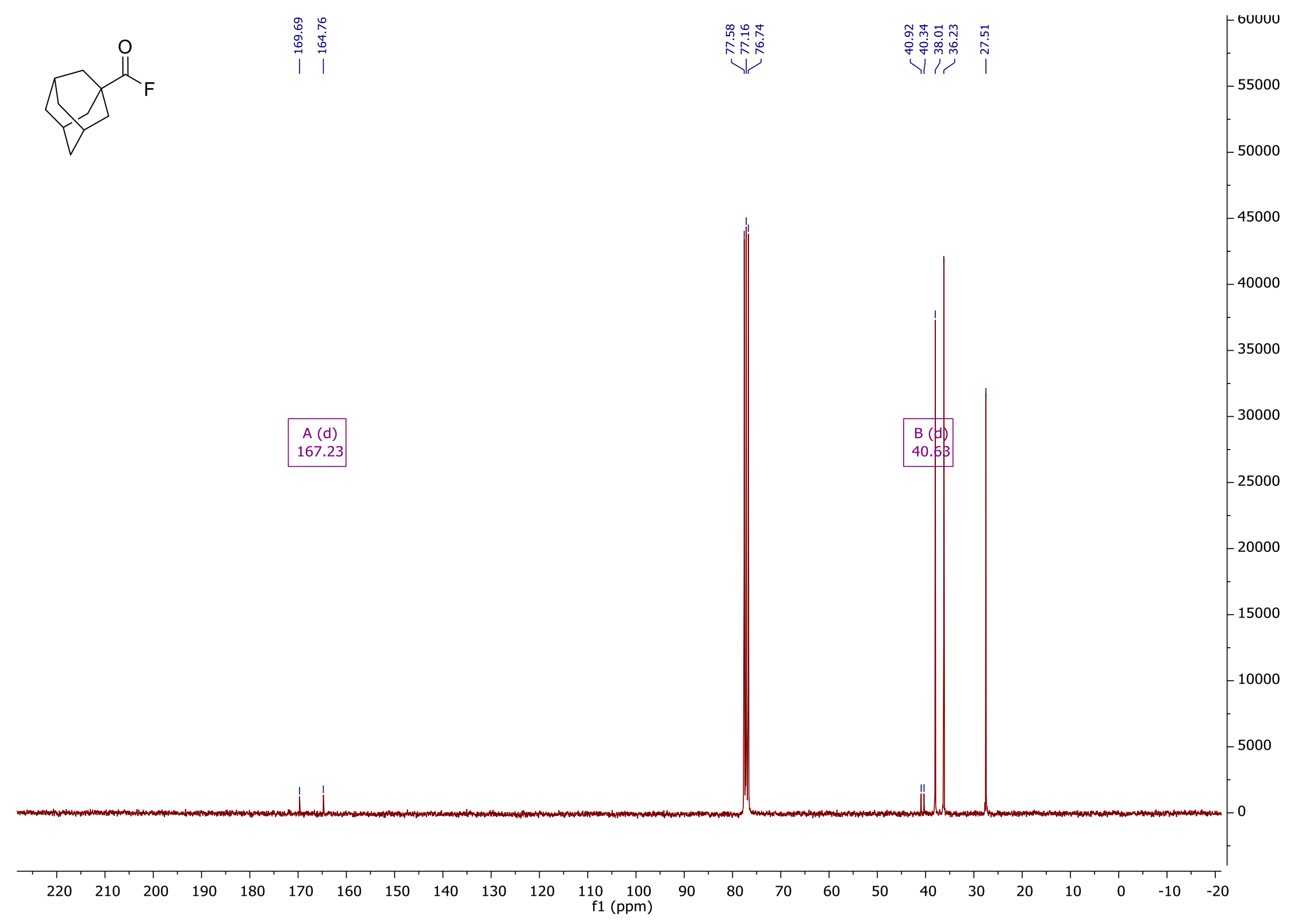


10c $\left({ }^{19} \mathrm{~F}\right.$ NMR in $\left.\mathrm{CDCl}_{3}\right)(282 \mathrm{MHz})$

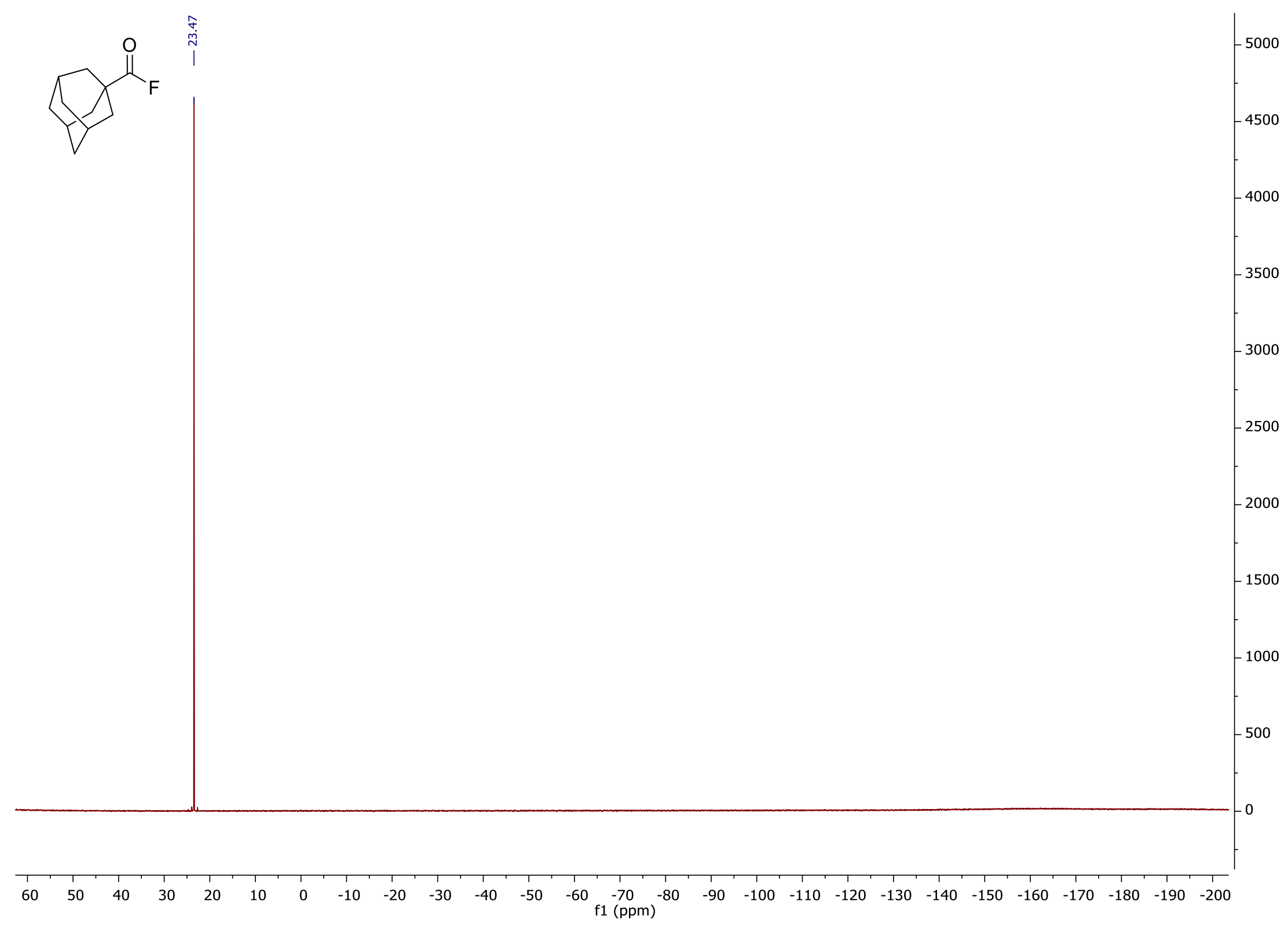


10d $\left({ }^{1} \mathrm{H}\right.$ NMR in $\left.\mathrm{CDCl}_{3}\right)(300 \mathrm{MHz})$

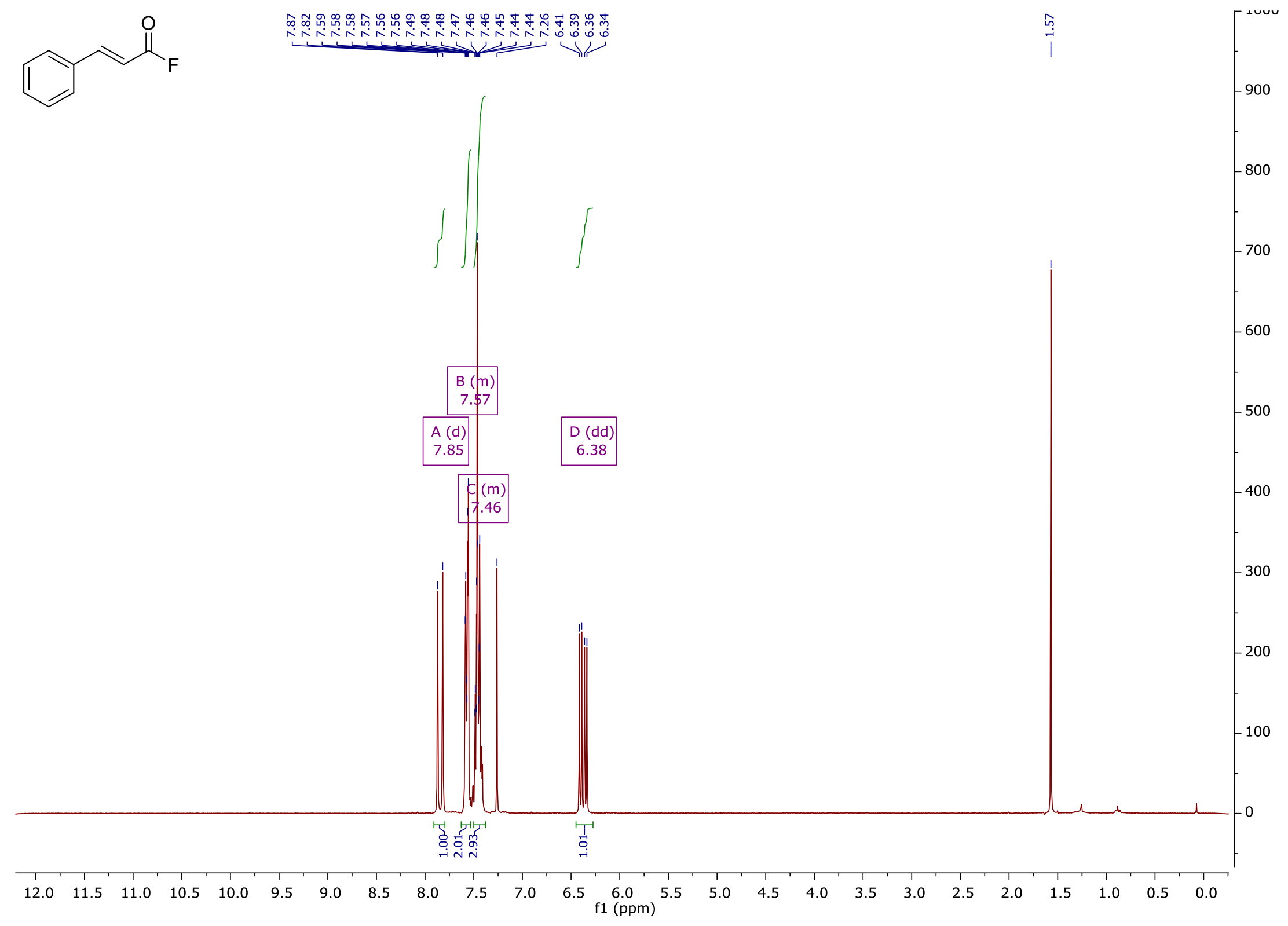


$\operatorname{10d}\left({ }^{13} \mathrm{C}\right.$ NMR in $\left.\mathrm{CDCl}_{3}\right)(101 \mathrm{MHz})$

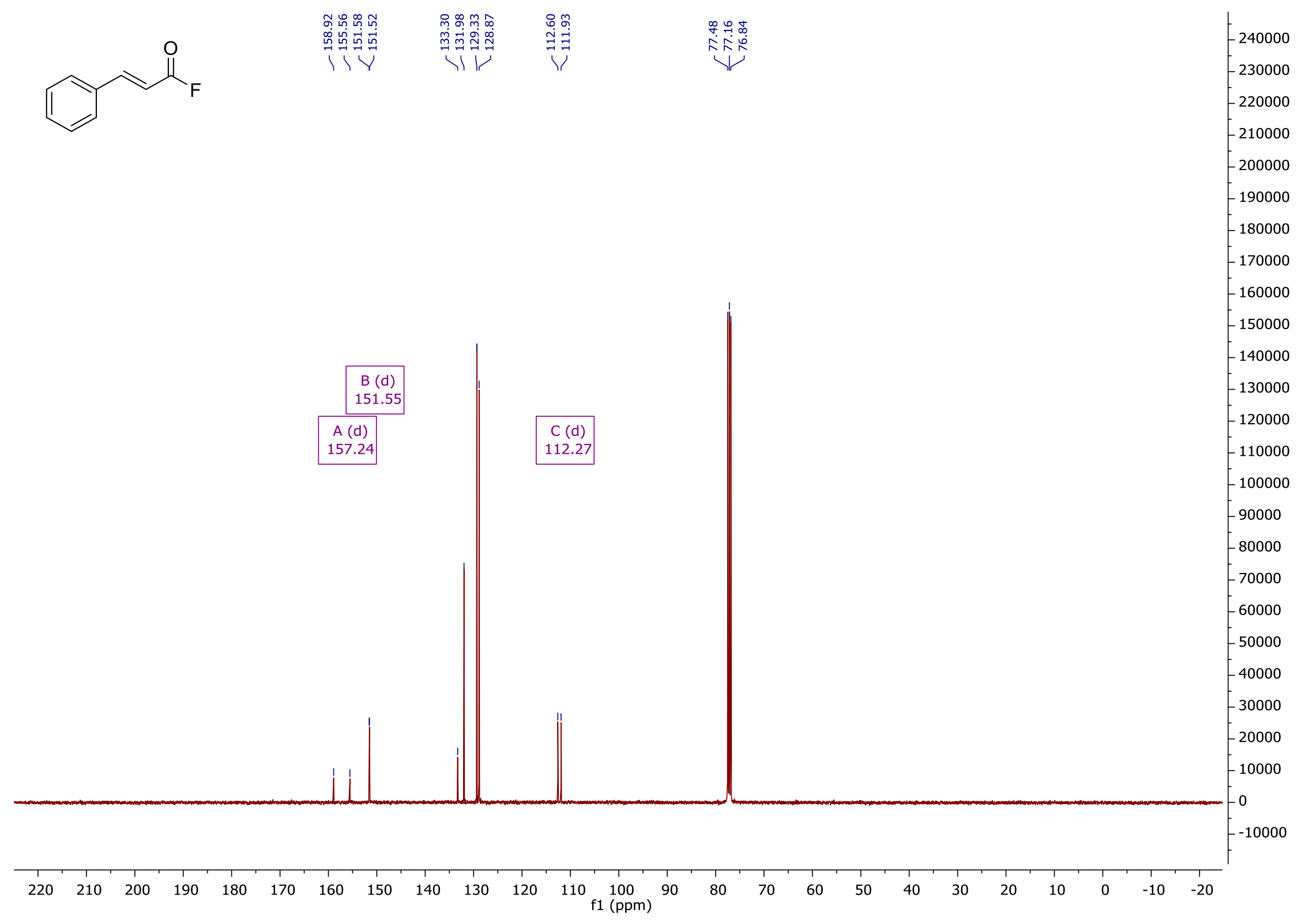


$\operatorname{10d}\left({ }^{19} \mathrm{~F}\right.$ NMR in $\left.\mathrm{CDCl}_{3}\right)(282 \mathrm{MHz})$

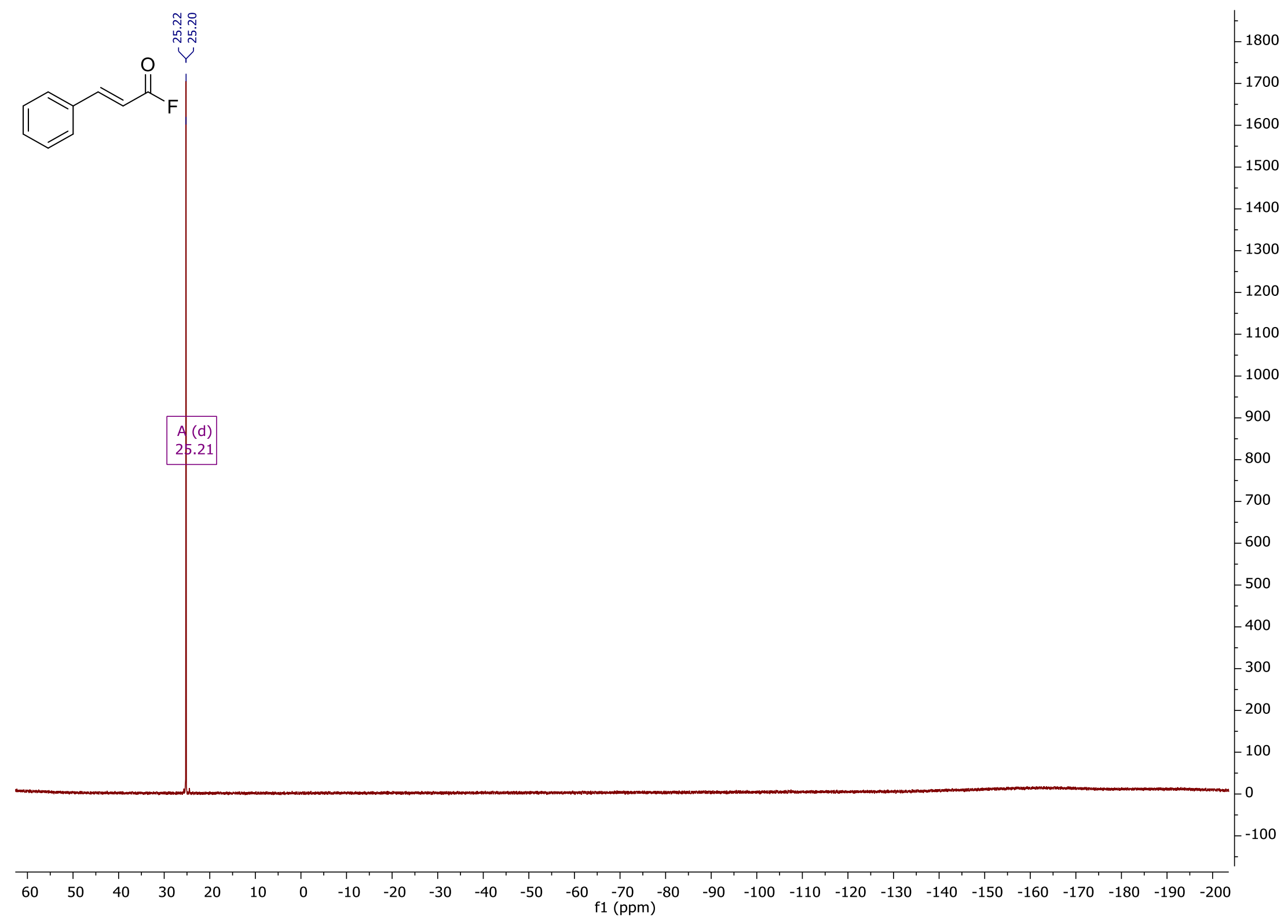


10e $\left({ }^{1} \mathrm{H}\right.$ NMR in $\left.\mathrm{CDCl}_{3}\right)(300 \mathrm{MHz})$

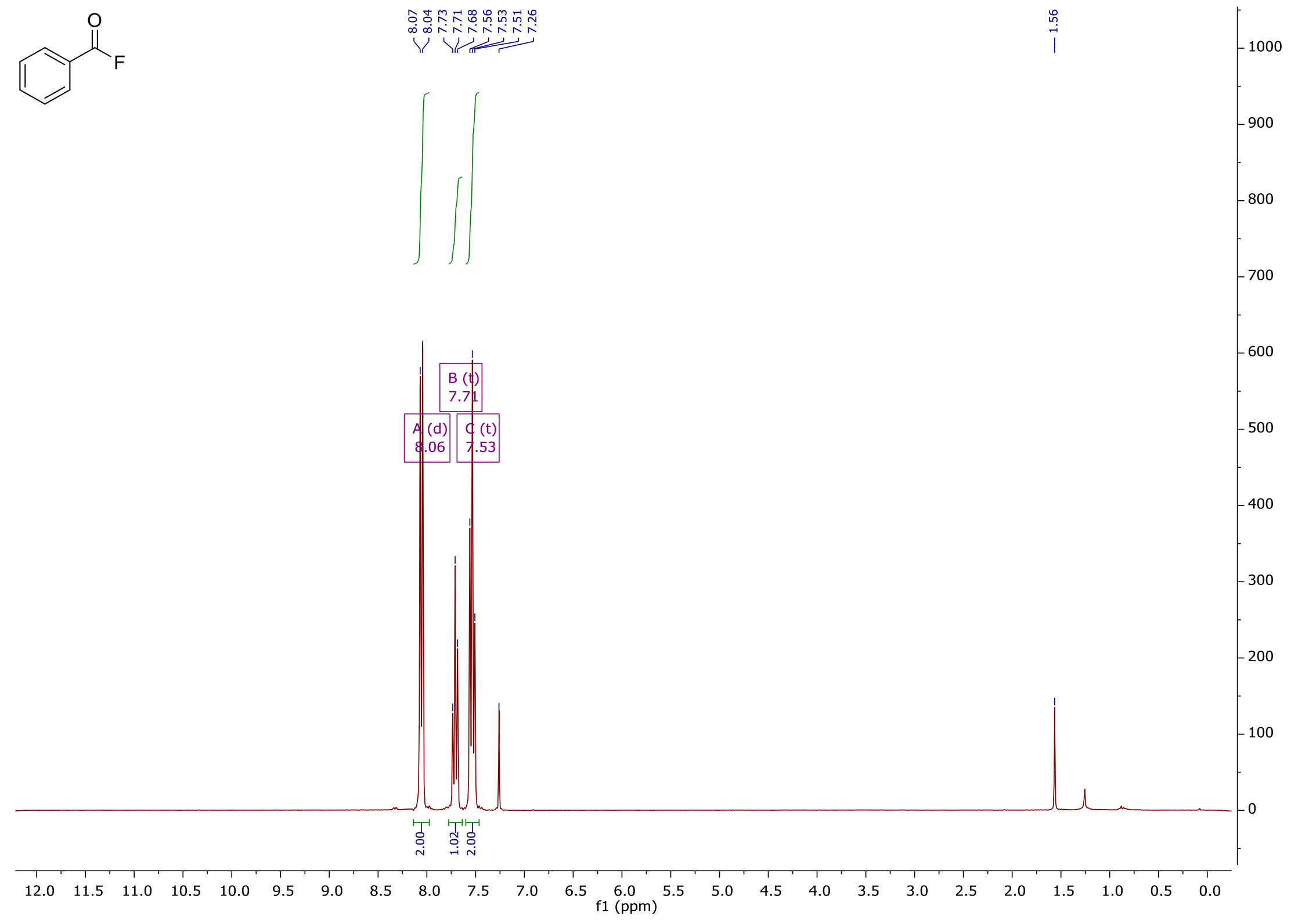


10e $\left({ }^{13} \mathrm{C}\right.$ NMR in $\left.\mathrm{CDCl}_{3}\right)(75 \mathrm{MHz})$

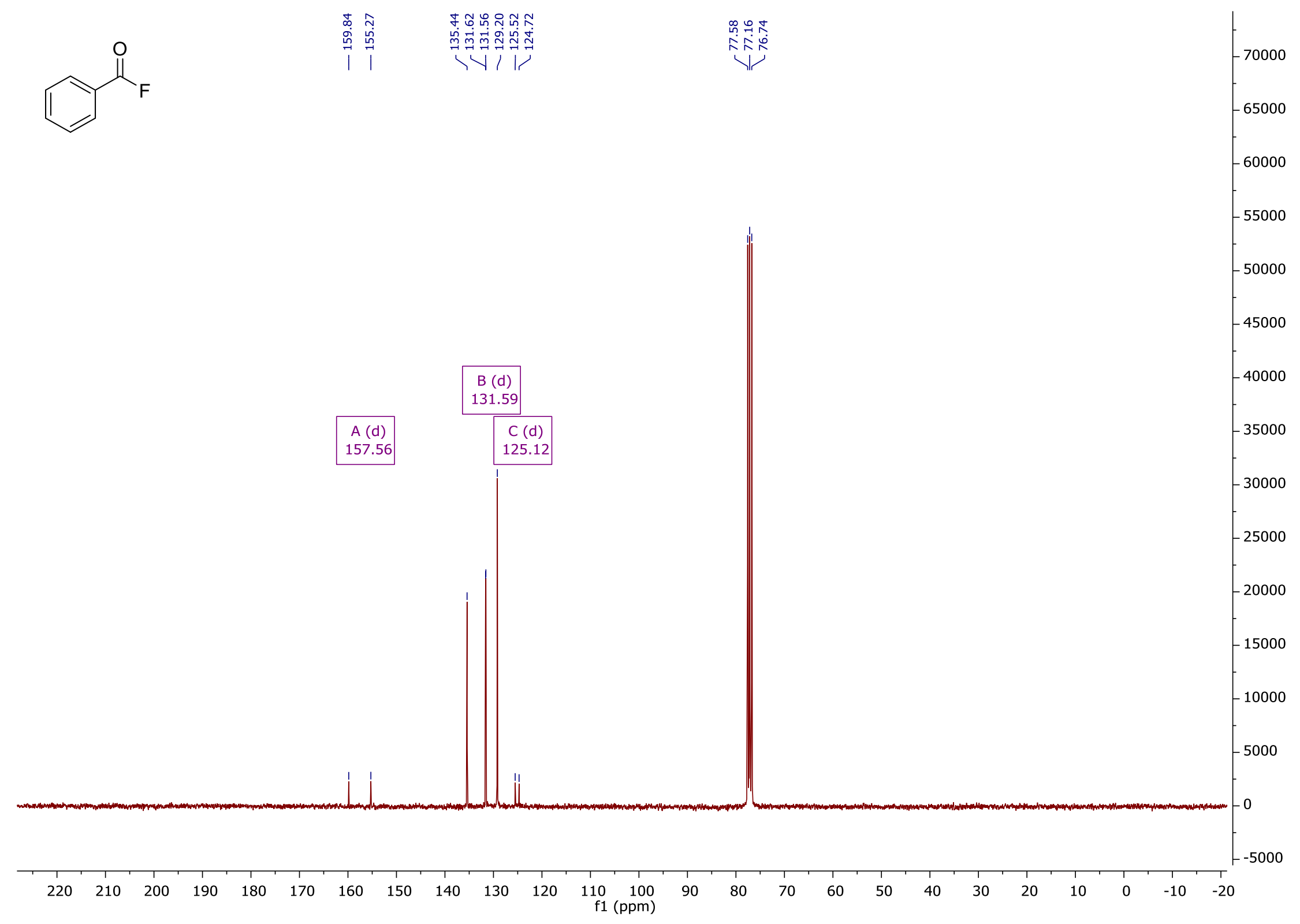


10e $\left({ }^{19} \mathrm{~F}\right.$ NMR in $\left.\mathrm{CDCl}_{3}\right)(282 \mathrm{MHz})$

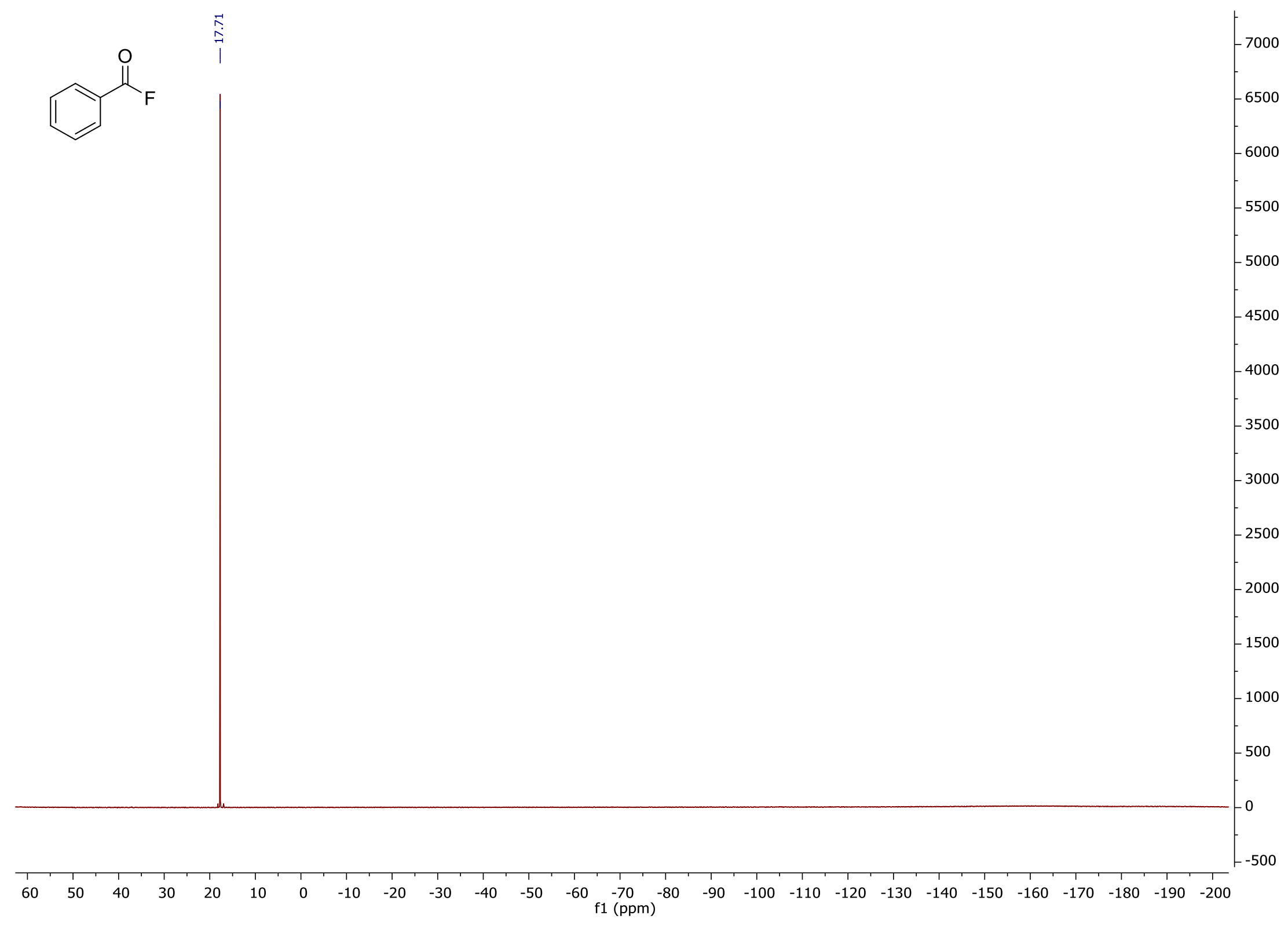


$10 f\left({ }^{1} \mathrm{H}\right.$ NMR in $\left.\mathrm{CDCl}_{3}\right)(300 \mathrm{MHz})$
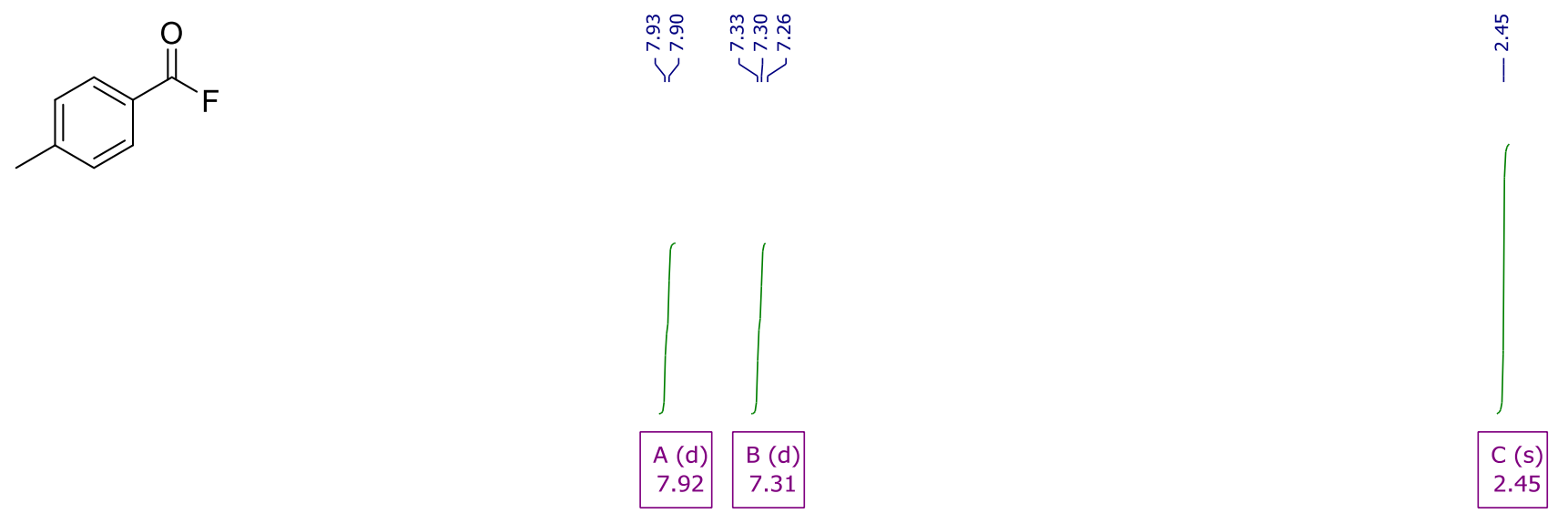

4200

$-4000$

$-3800$

$-3600$

$-3400$

$-3200$

$-3000$

$-2800$

$-2600$

$-2400$

$-2200$

$-2000$

$-1800$

1600

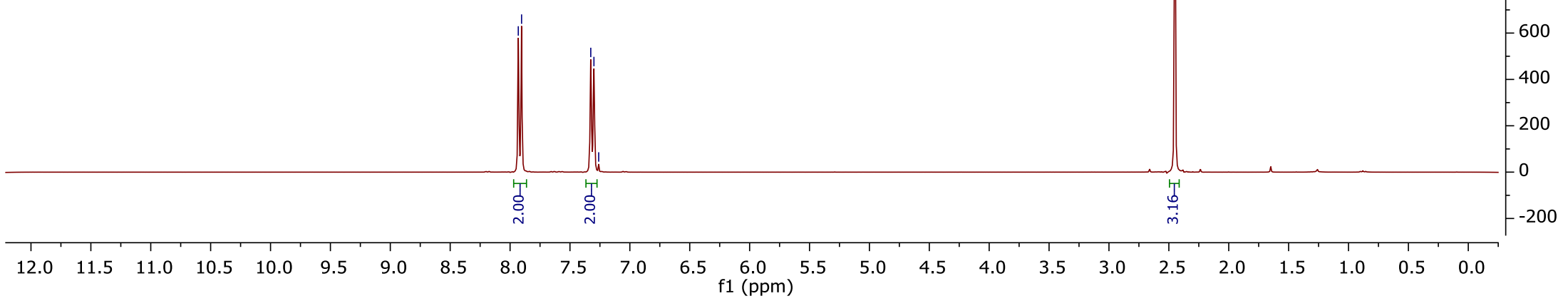


10f $\left({ }^{13} \mathrm{C}\right.$ NMR in $\left.\mathrm{CDCl}_{3}\right)(75 \mathrm{MHz})$

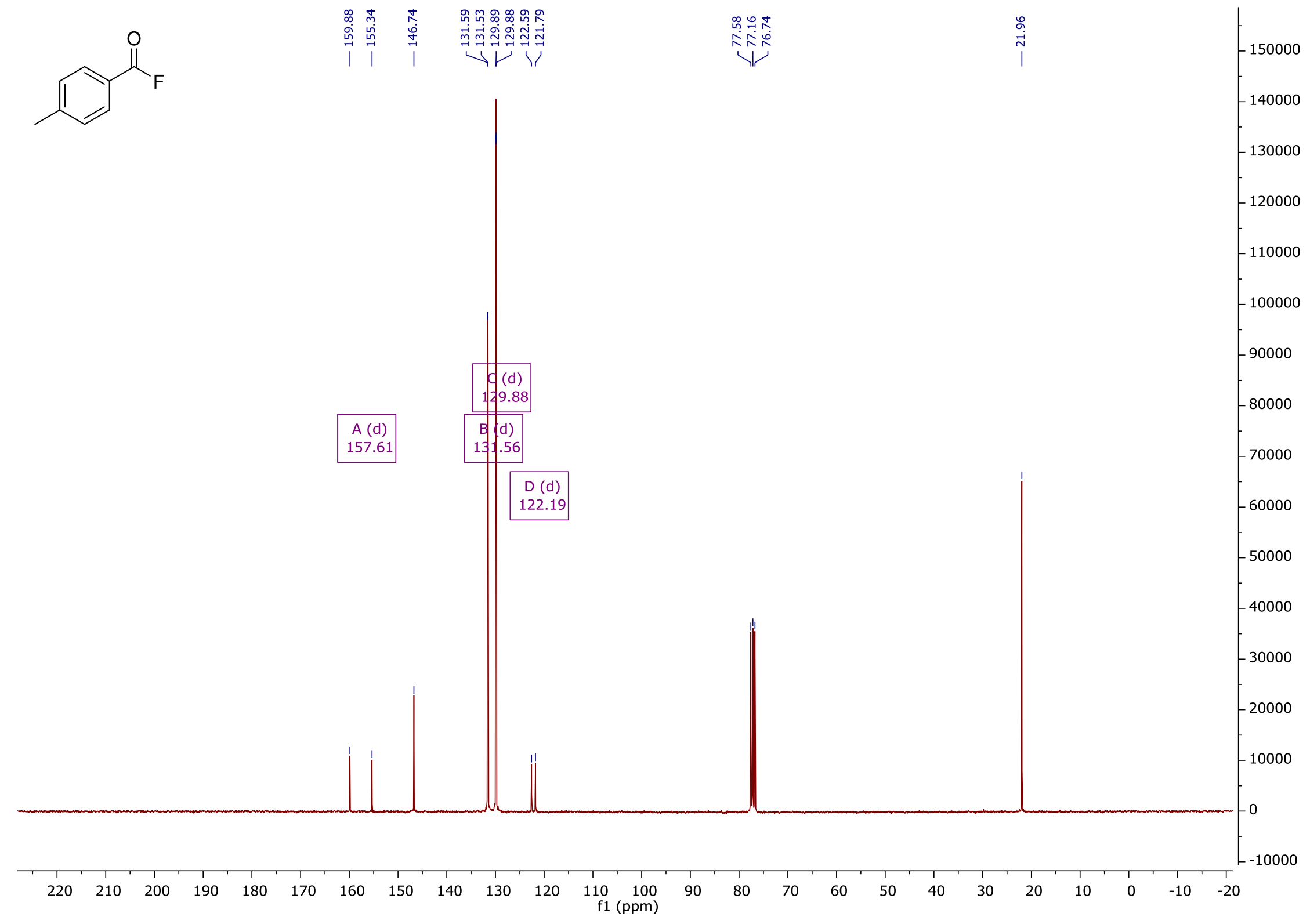


$10 f\left({ }^{19} \mathrm{~F} \mathrm{NMR}\right.$ in $\left.\mathrm{CDCl}_{3}\right)(282 \mathrm{MHz})$

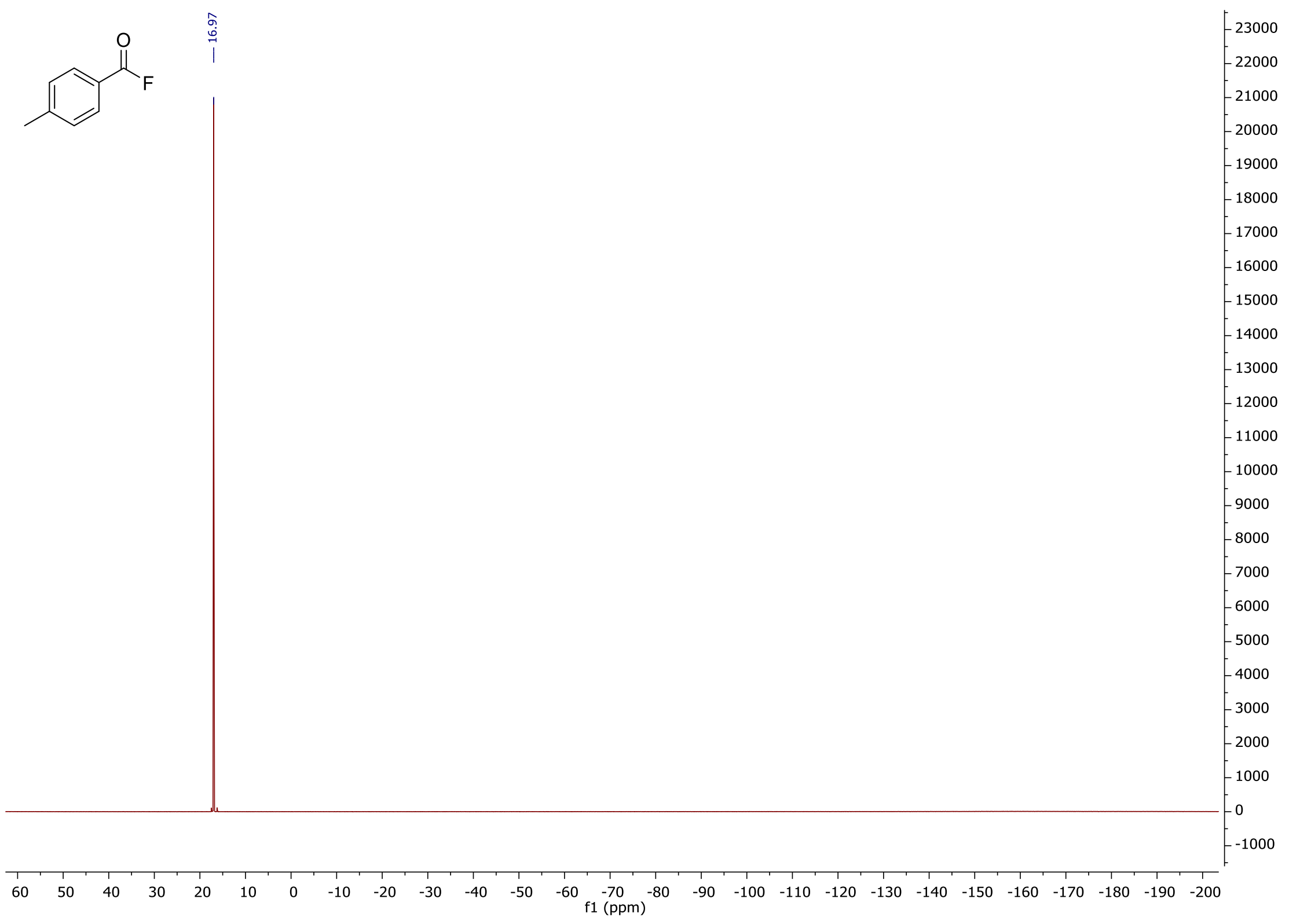


$\operatorname{10g}\left({ }^{1} \mathrm{H} \mathrm{NMR}\right.$ in $\left.\mathrm{CDCl}_{3}\right)(300 \mathrm{MHz})$

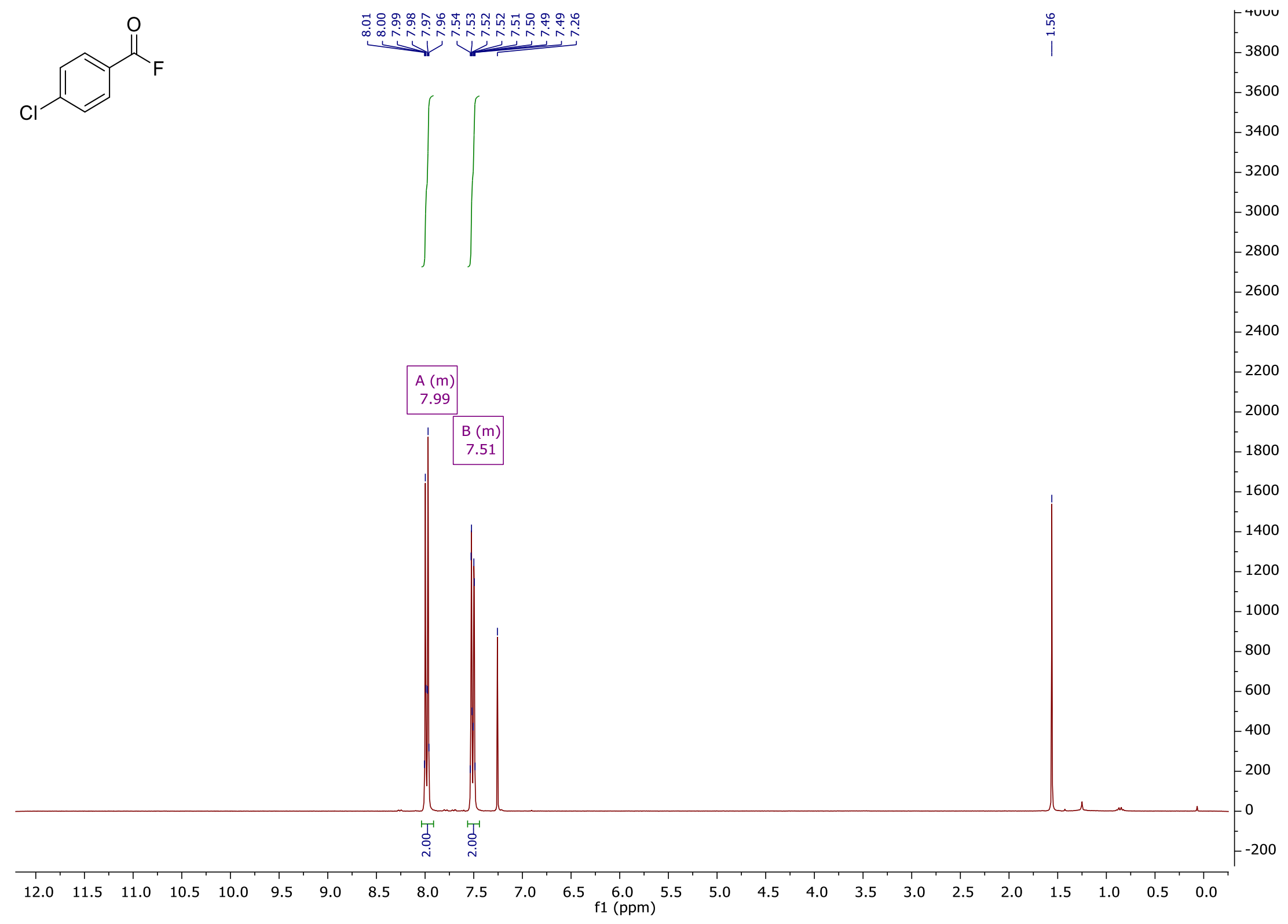


$\log \left({ }^{13} \mathrm{C} \mathrm{NMR}\right.$ in $\left.\mathrm{CDCl}_{3}\right)(75 \mathrm{MHz})$
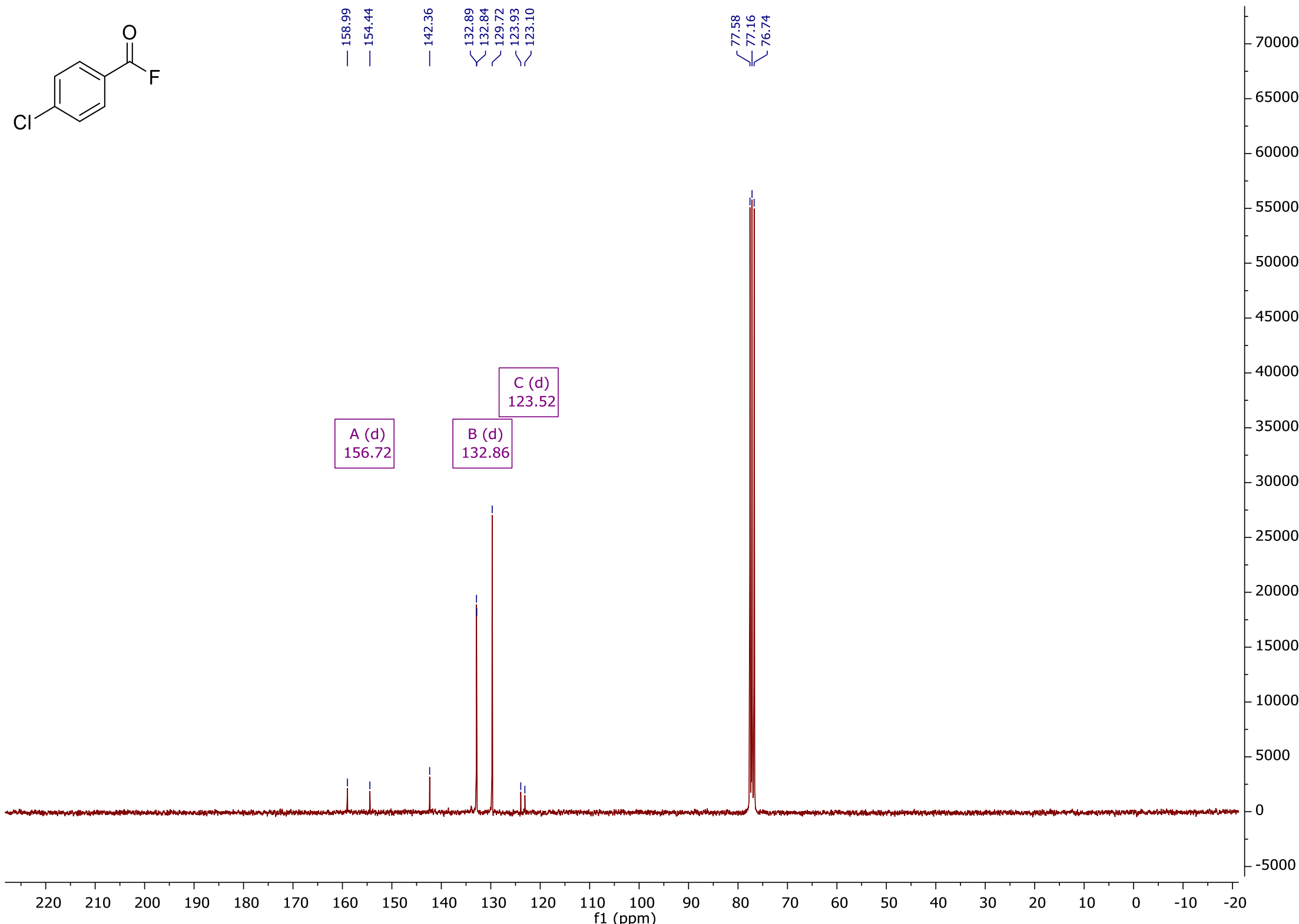
$\operatorname{10g}\left({ }^{19} \mathrm{~F}\right.$ NMR in $\left.\mathrm{CDCl}_{3}\right)(282 \mathrm{MHz})$

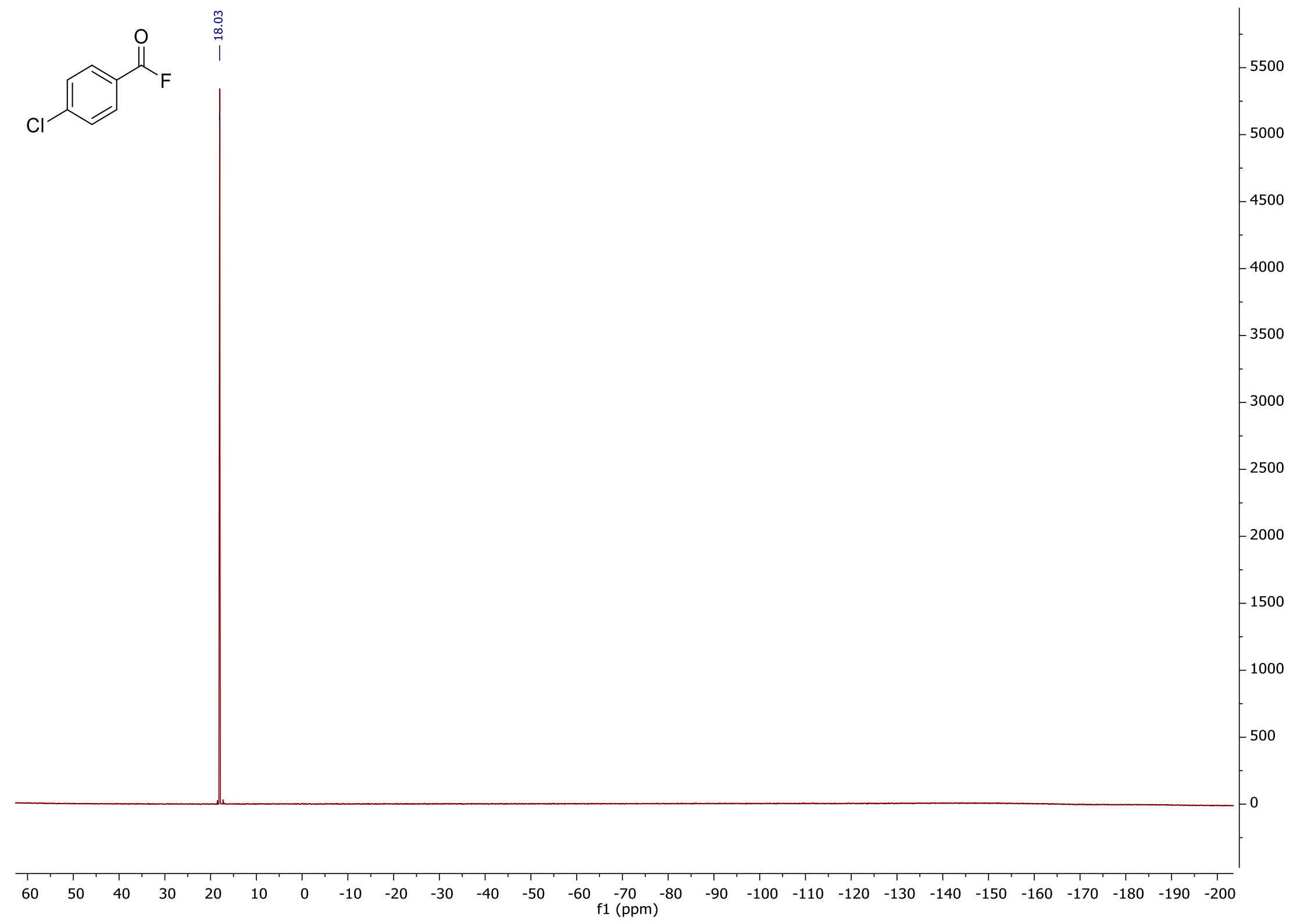


10h $\left({ }^{1} \mathrm{H} \mathrm{NMR}\right.$ in $\left.\mathrm{CDCl}_{3}\right)(300 \mathrm{MHz})$

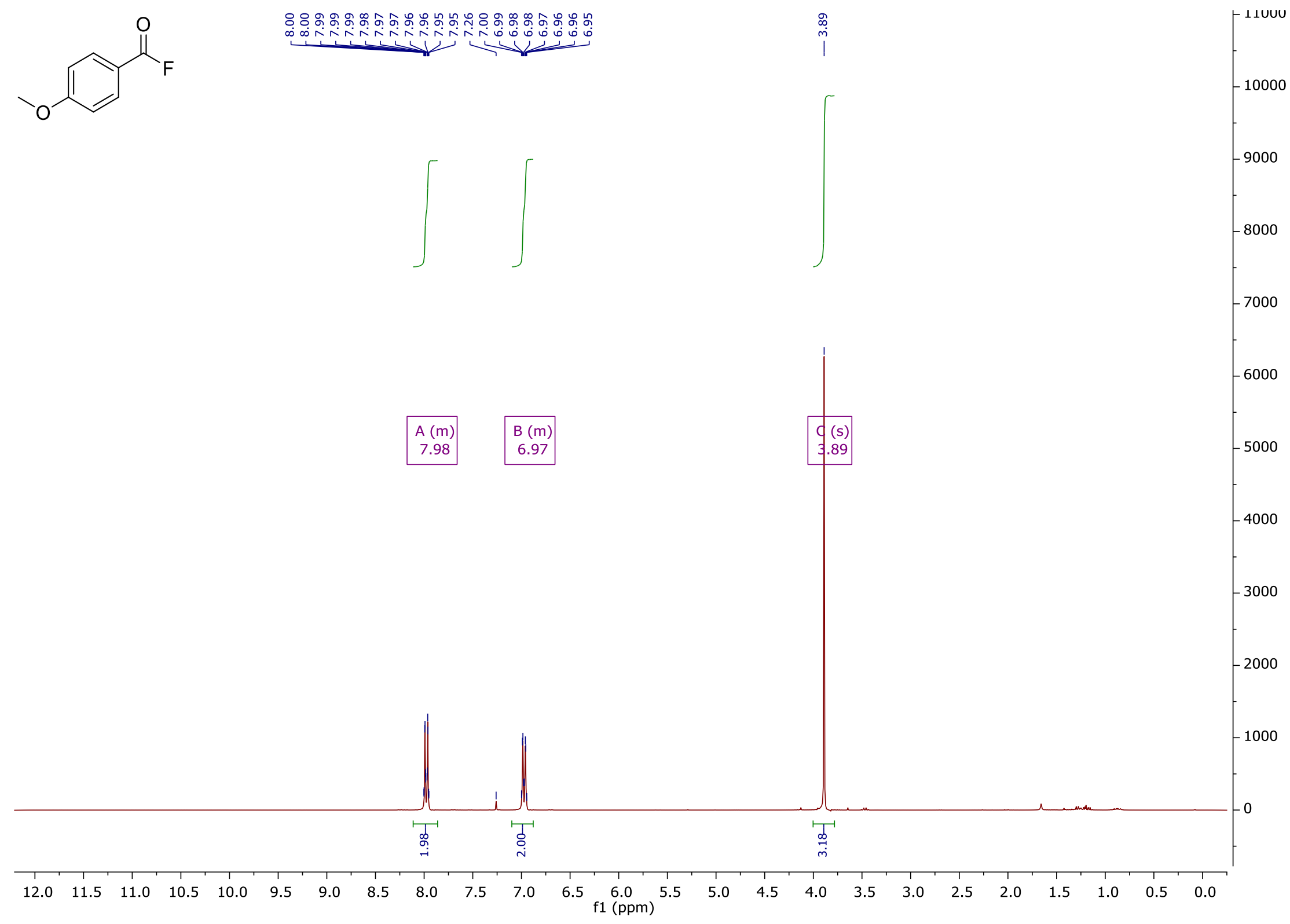


10h $\left({ }^{13} \mathrm{C}\right.$ NMR in $\left.\mathrm{CDCl}_{3}\right)(75 \mathrm{MHz})$

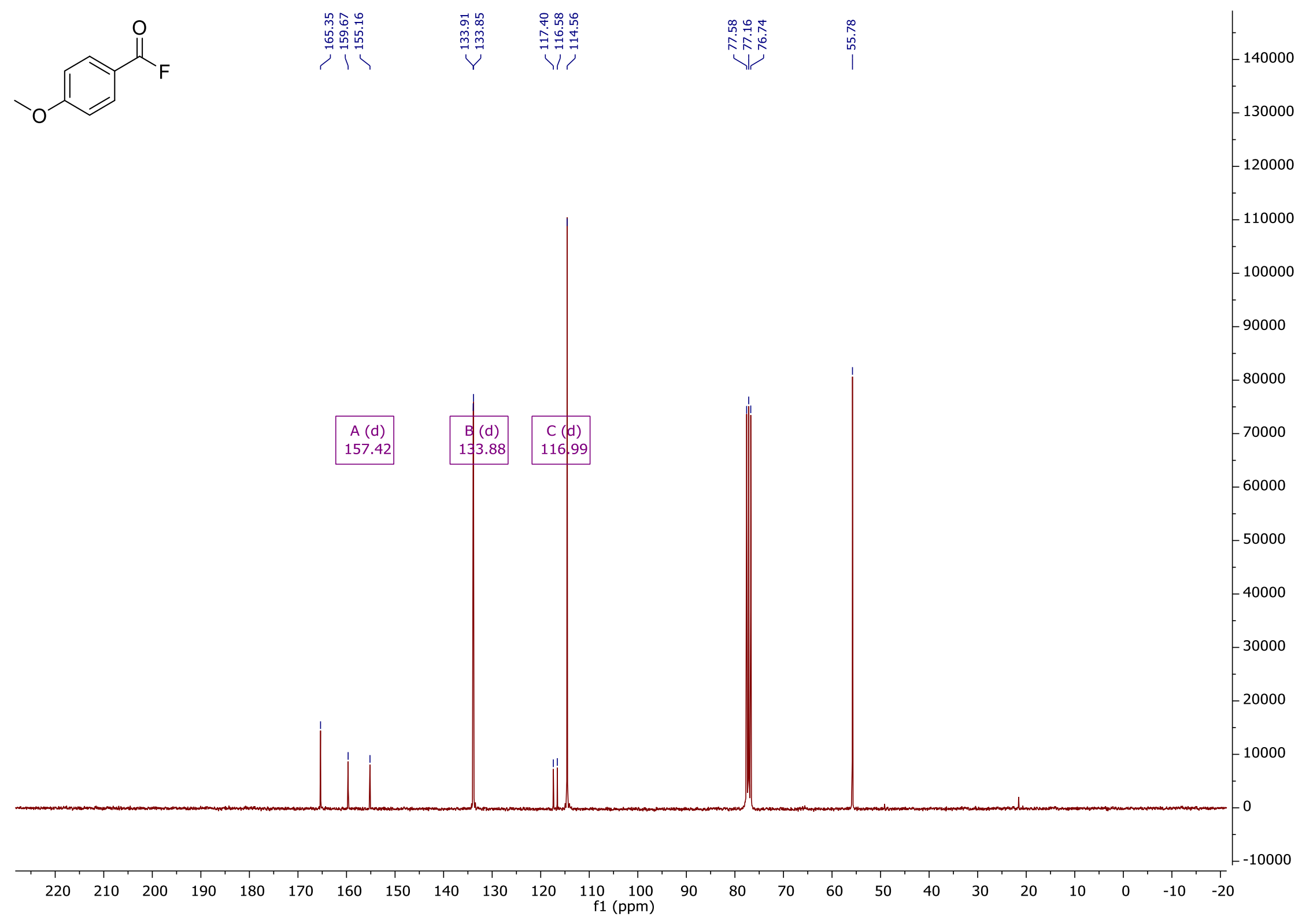


10h $\left({ }^{19} \mathrm{~F}\right.$ NMR in $\left.\mathrm{CDCl}_{3}\right)(282 \mathrm{MHz})$

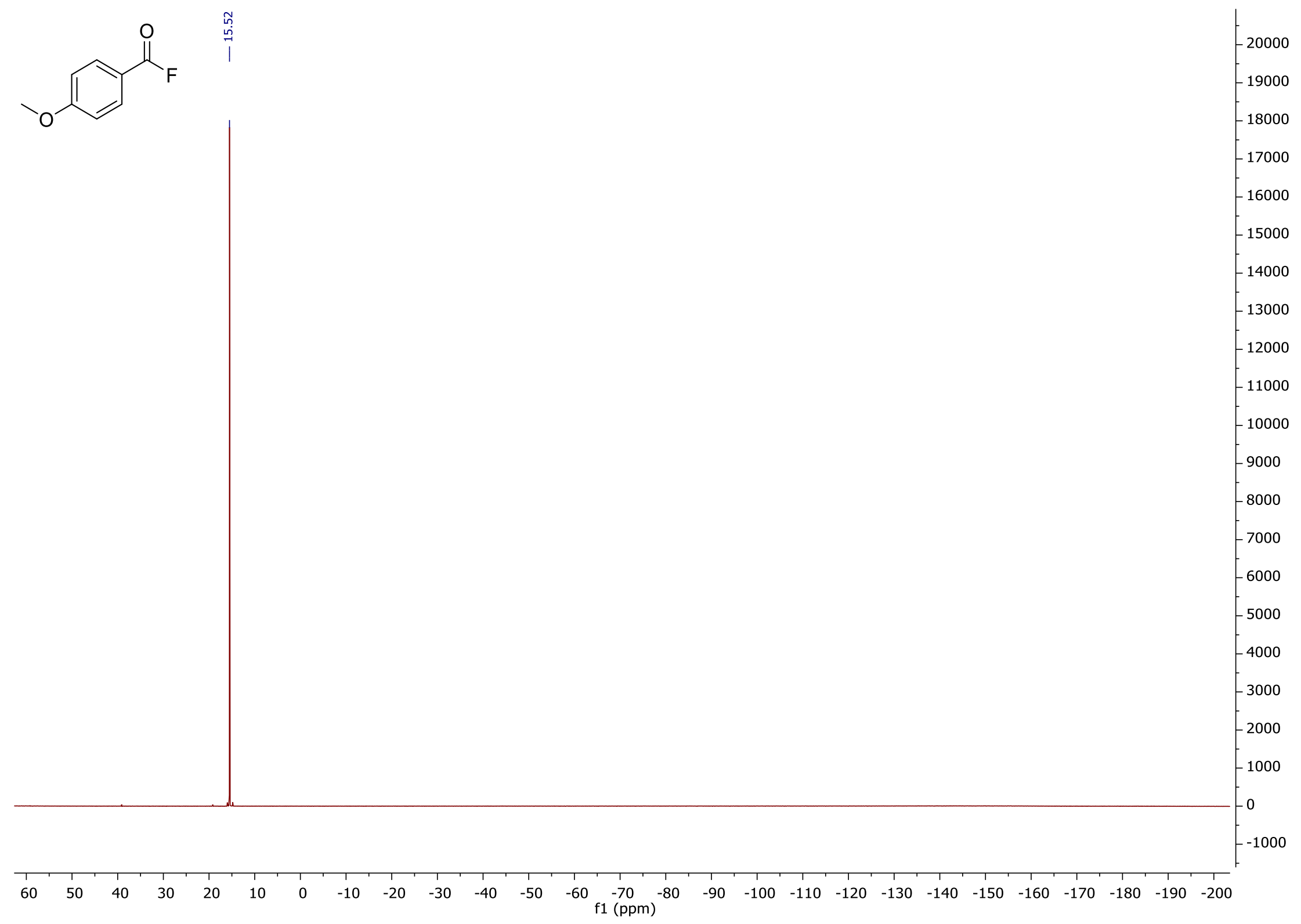


10i $\left({ }^{1} \mathrm{H}\right.$ NMR in $\left.\mathrm{CDCl}_{3}\right)(300 \mathrm{MHz})$

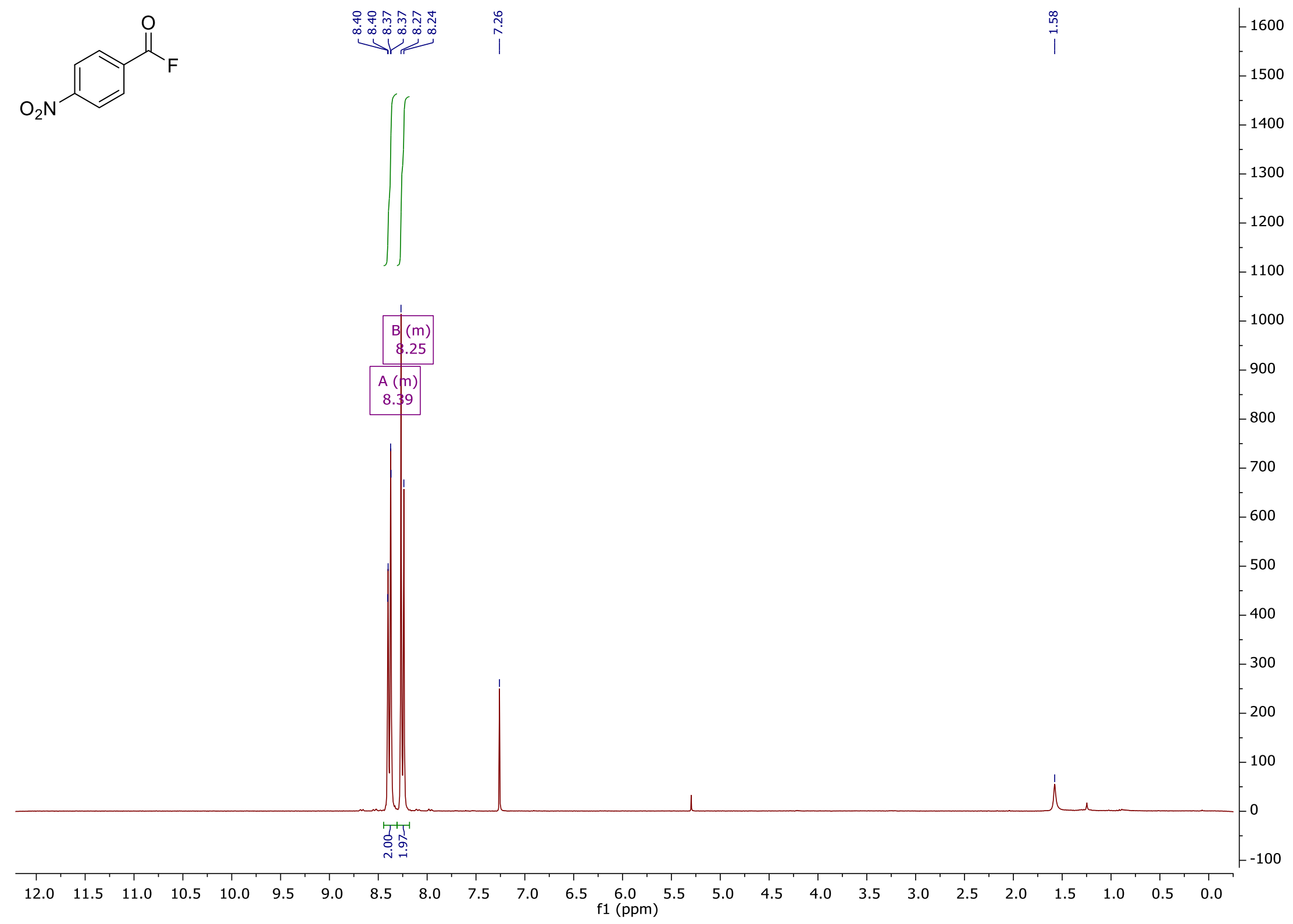


10i $\left({ }^{13} \mathrm{C} \mathrm{NMR} \mathrm{in} \mathrm{CDCl}_{3}\right)(75 \mathrm{MHz})$

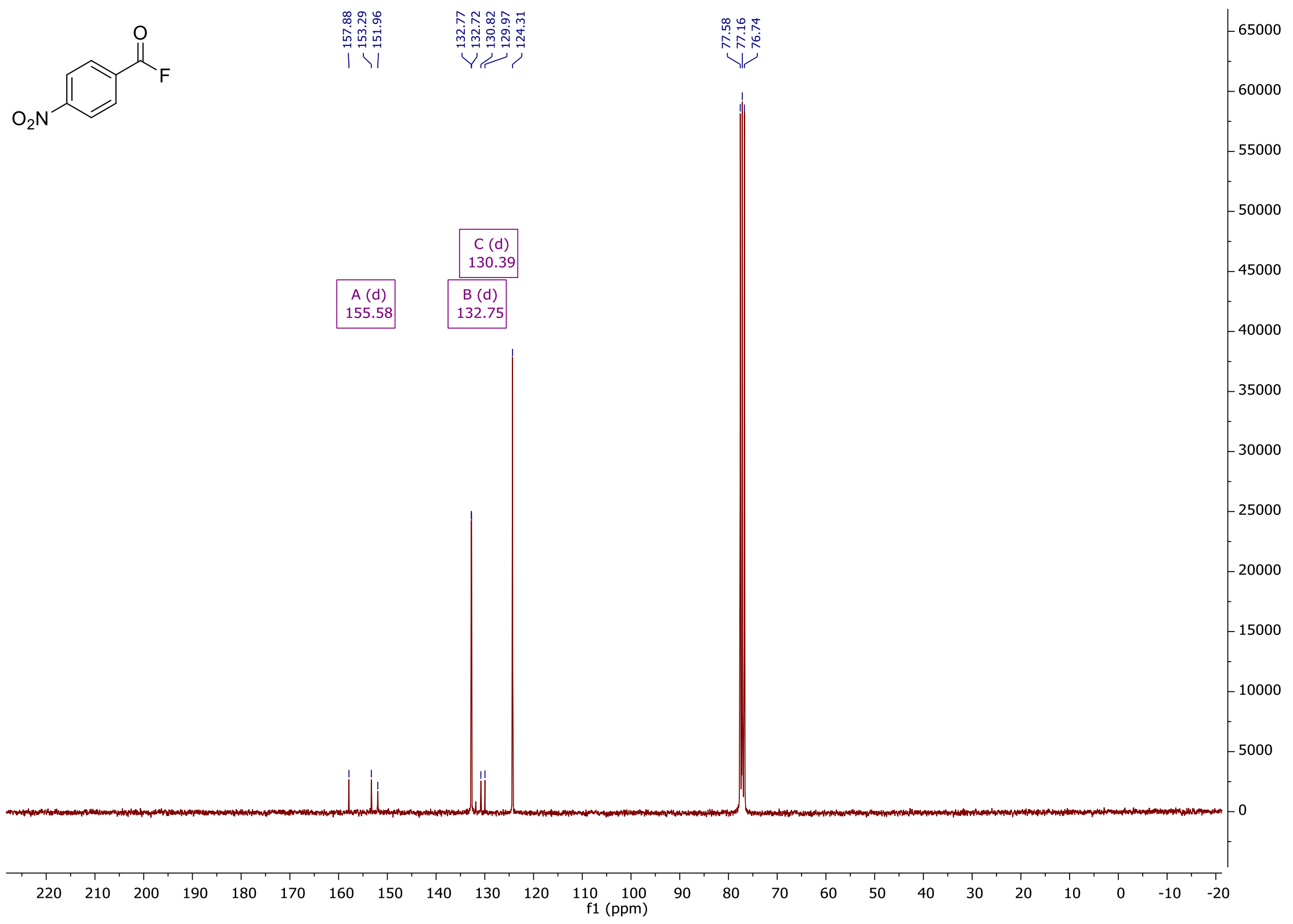


10i $\left({ }^{19} \mathrm{~F}\right.$ NMR in $\left.\mathrm{CDCl}_{3}\right)(282 \mathrm{MHz})$

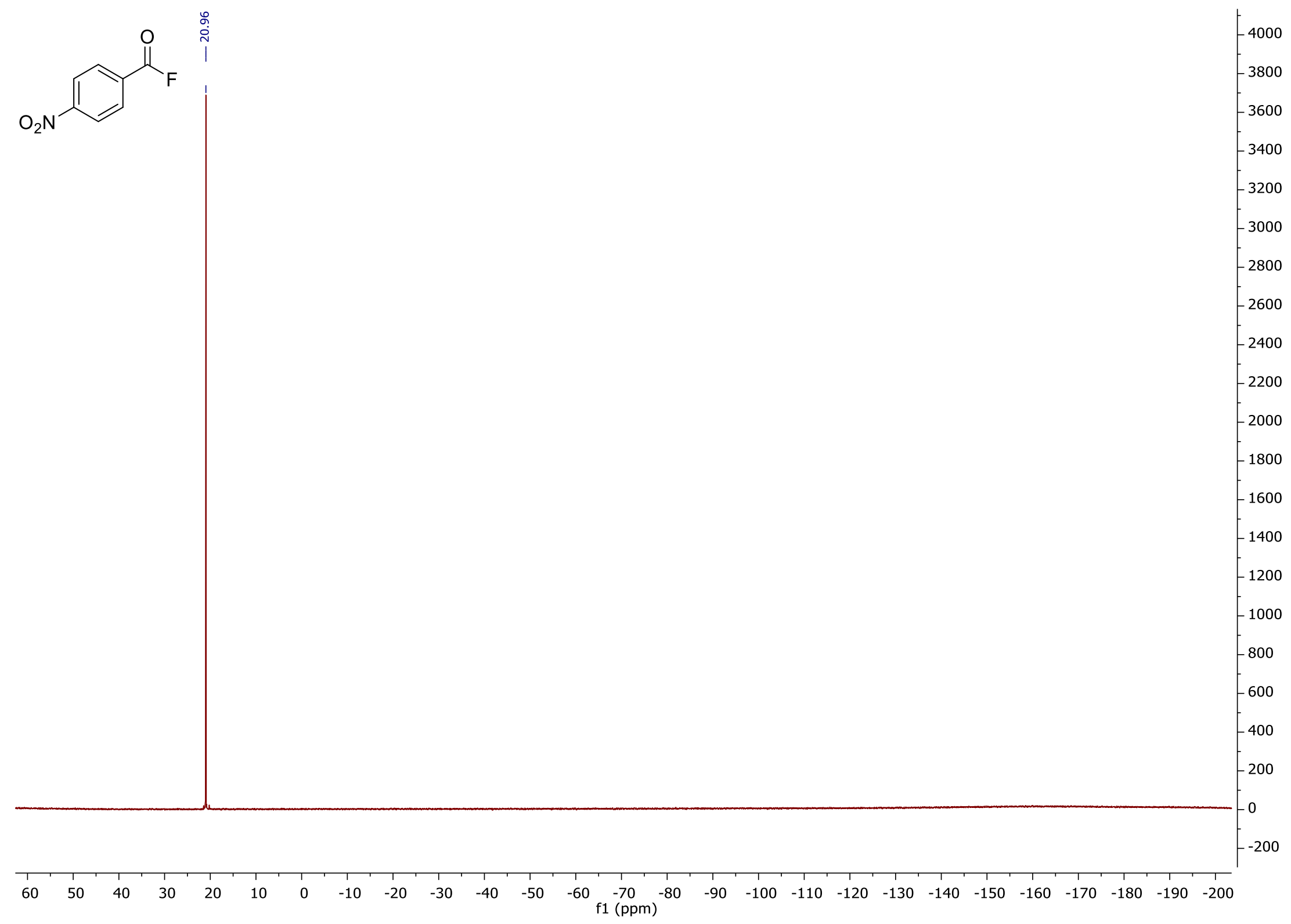


10j $\left({ }^{1} \mathrm{H} \mathrm{NMR}\right.$ in $\left.\mathrm{CDCl}_{3}\right)(300 \mathrm{MHz})$

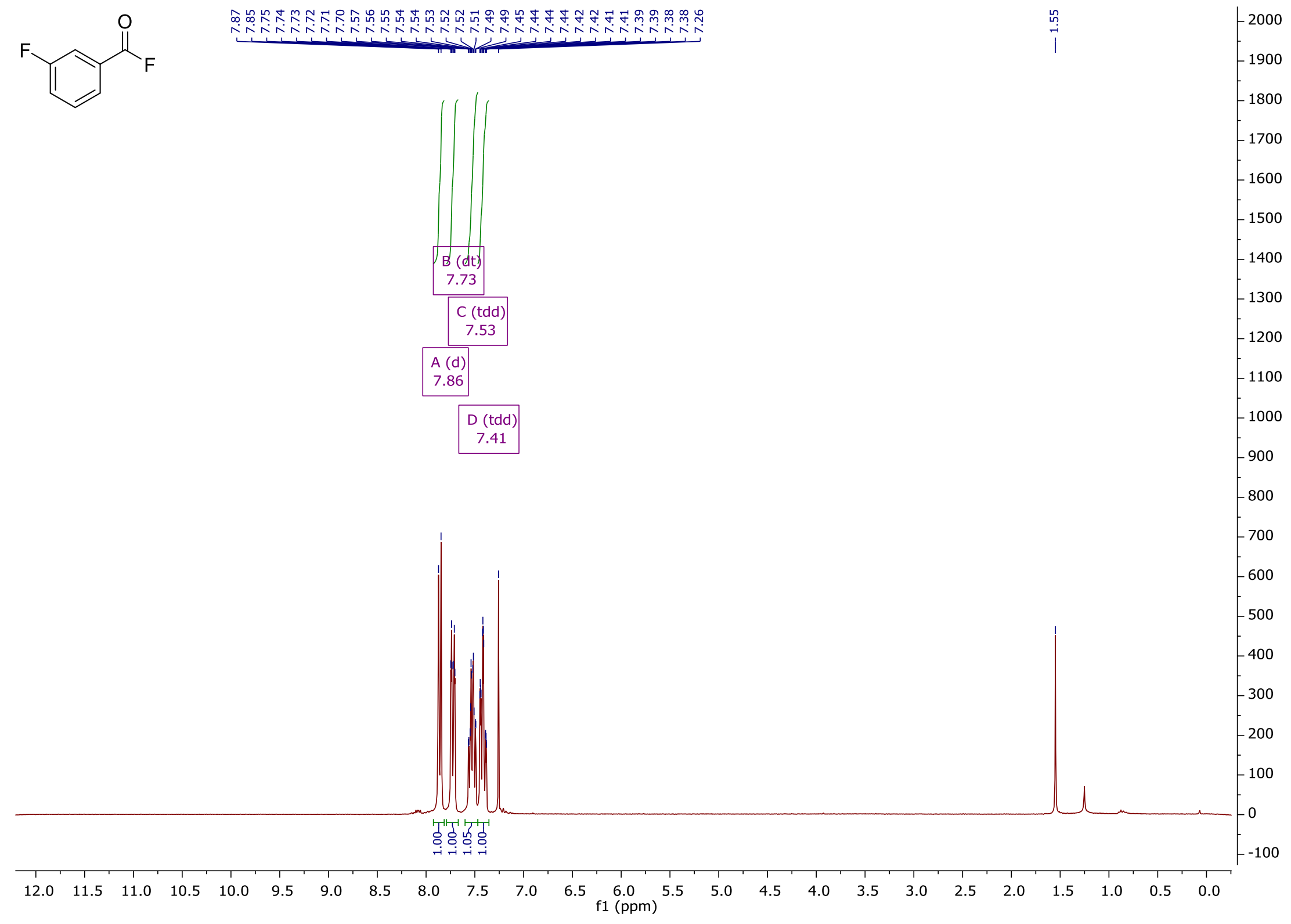


10j $\left({ }^{13} \mathrm{C}\right.$ NMR in $\left.\mathrm{CDCl}_{3}\right)(75 \mathrm{MHz})$

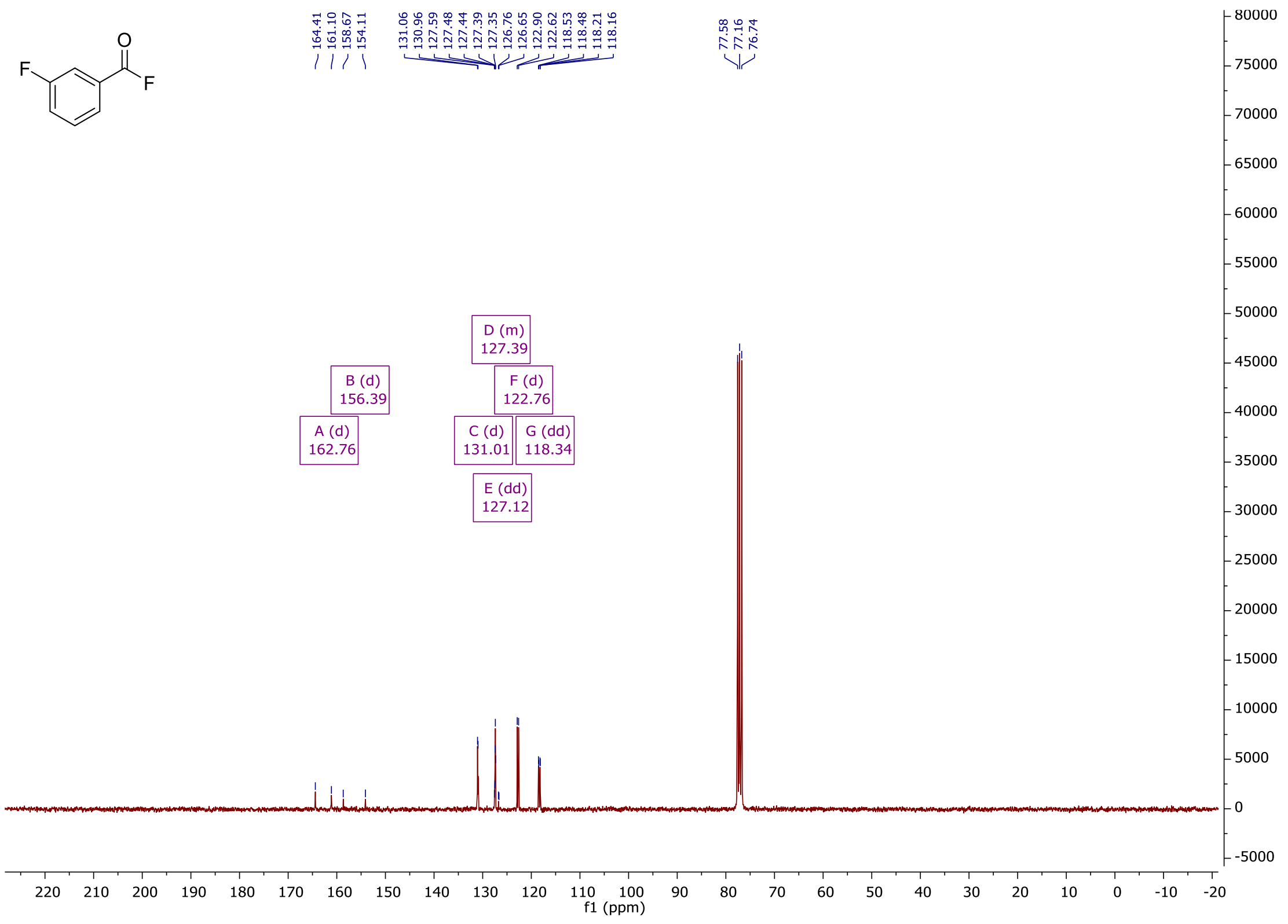


10j $\left({ }^{19} \mathrm{~F}\right.$ NMR in $\left.\mathrm{CDCl}_{3}\right)(282 \mathrm{MHz})$

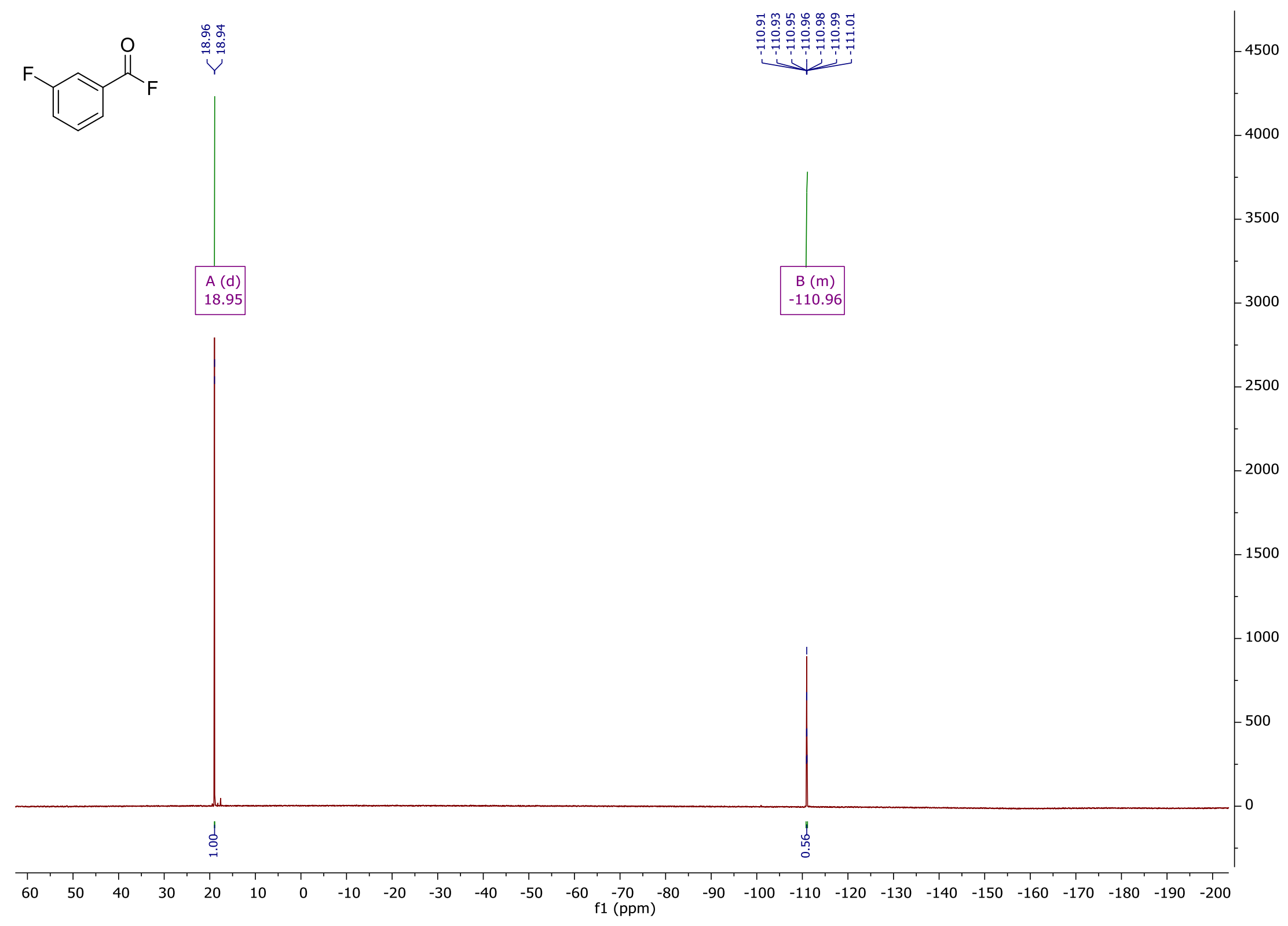


10k ( ${ }^{1} \mathrm{H}$ NMR in $\left.\mathrm{CDCl}_{3}\right)(300 \mathrm{MHz})$

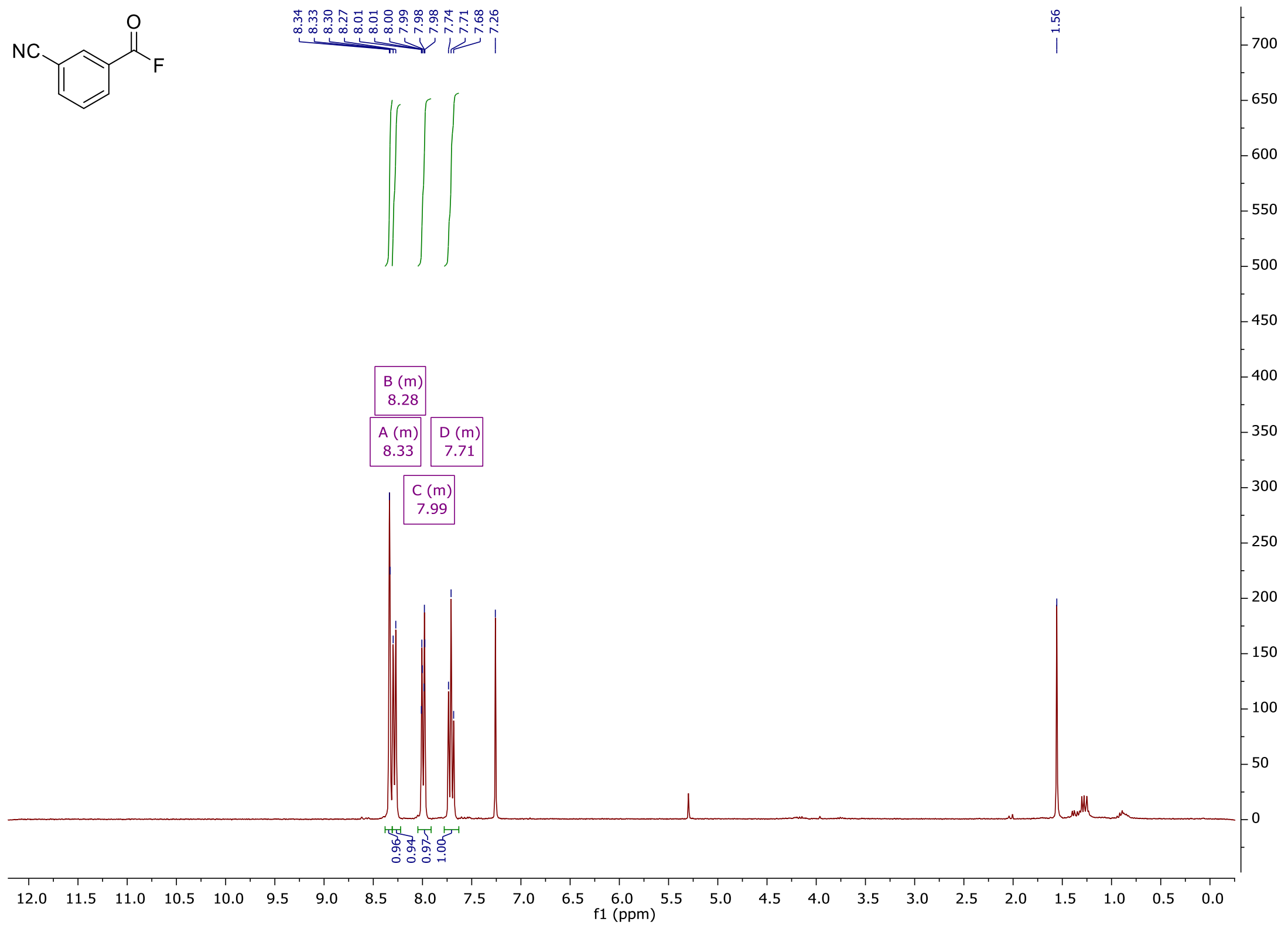


10k $\left({ }^{13} \mathrm{C} \mathrm{NMR}\right.$ in $\left.\mathrm{CDCl}_{3}\right)(75 \mathrm{MHz})$

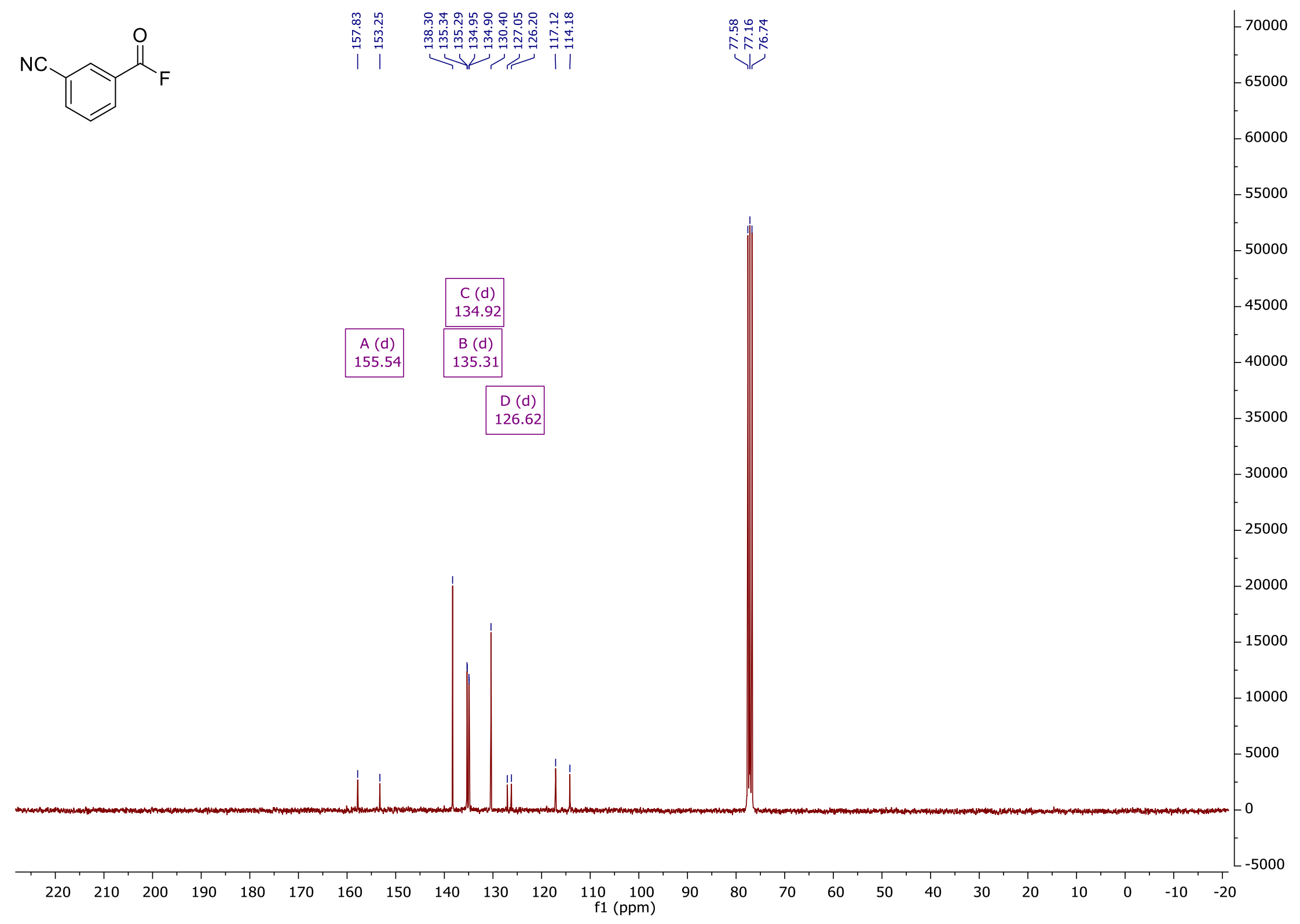


10k $\left({ }^{19} \mathrm{~F}\right.$ NMR in $\left.\mathrm{CDCl}_{3}\right)(282 \mathrm{MHz})$

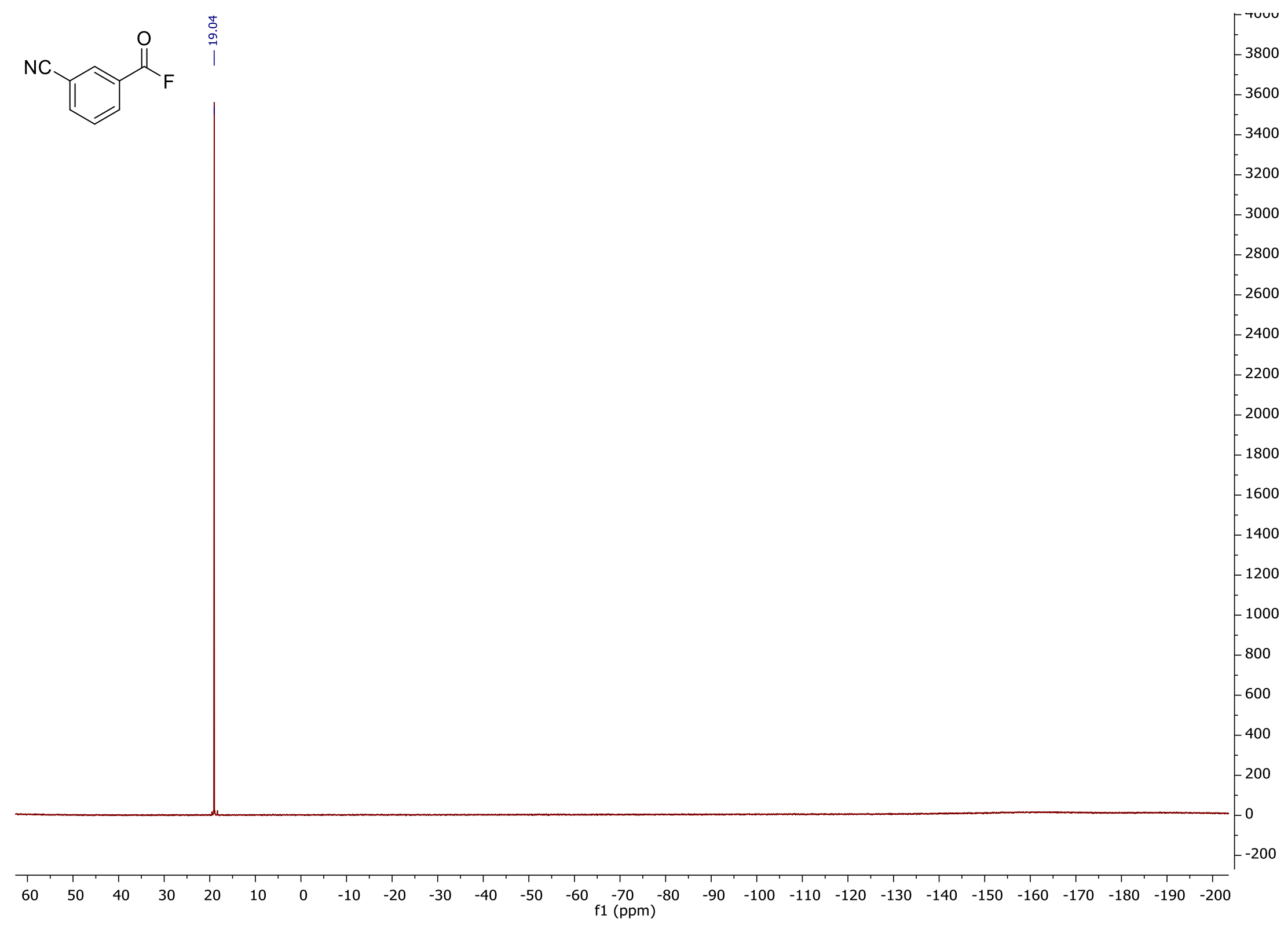


$101\left({ }^{1} \mathrm{H}\right.$ NMR in $\left.\mathrm{CDCl}_{3}\right)(300 \mathrm{MHz})$

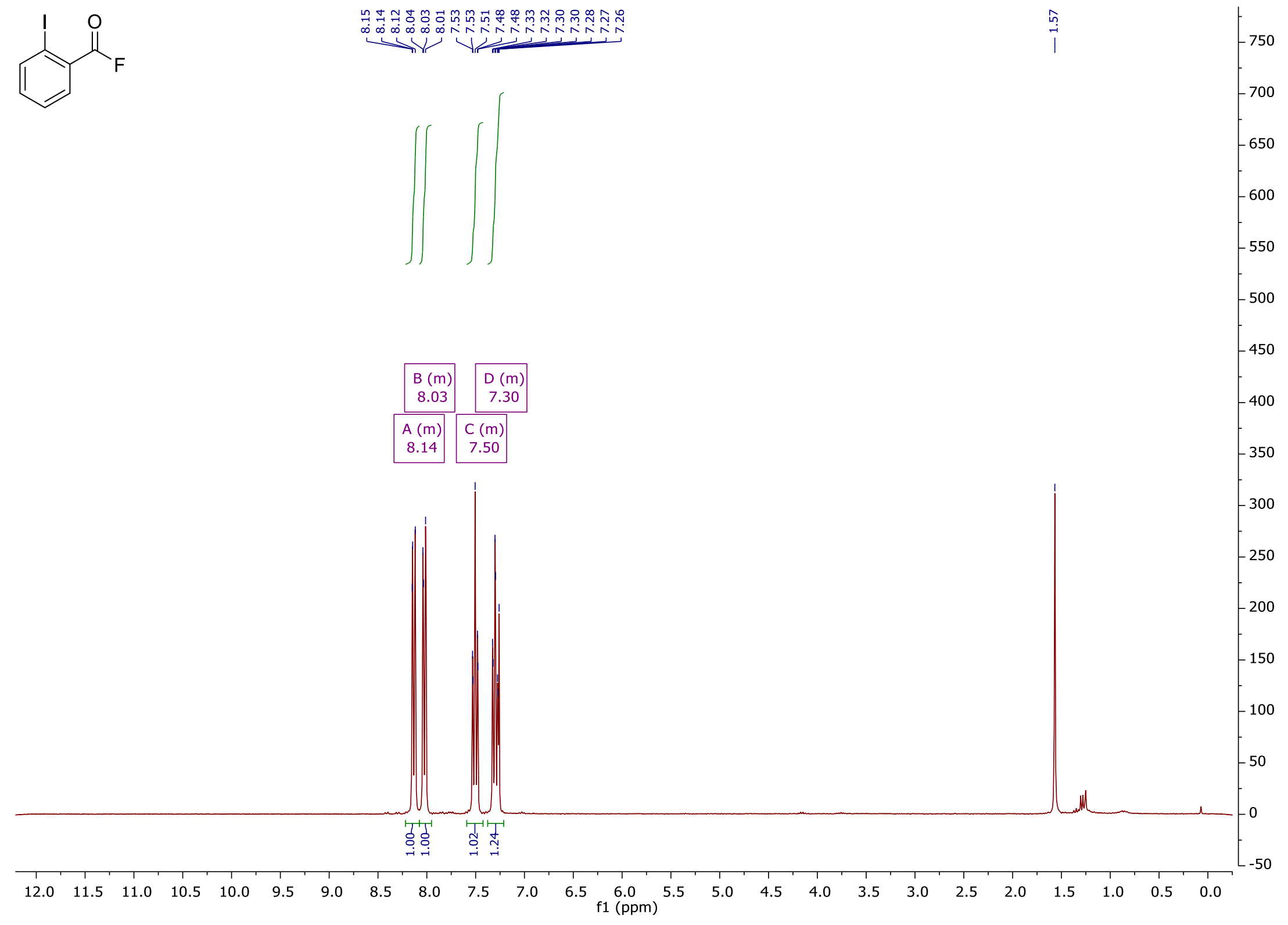


$101\left({ }^{13} \mathrm{C}\right.$ NMR in $\left.\mathrm{CDCl}_{3}\right)(75 \mathrm{MHz})$

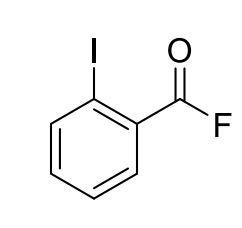

|

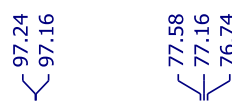

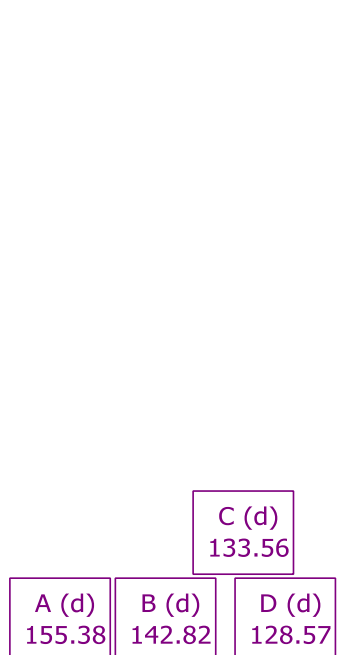
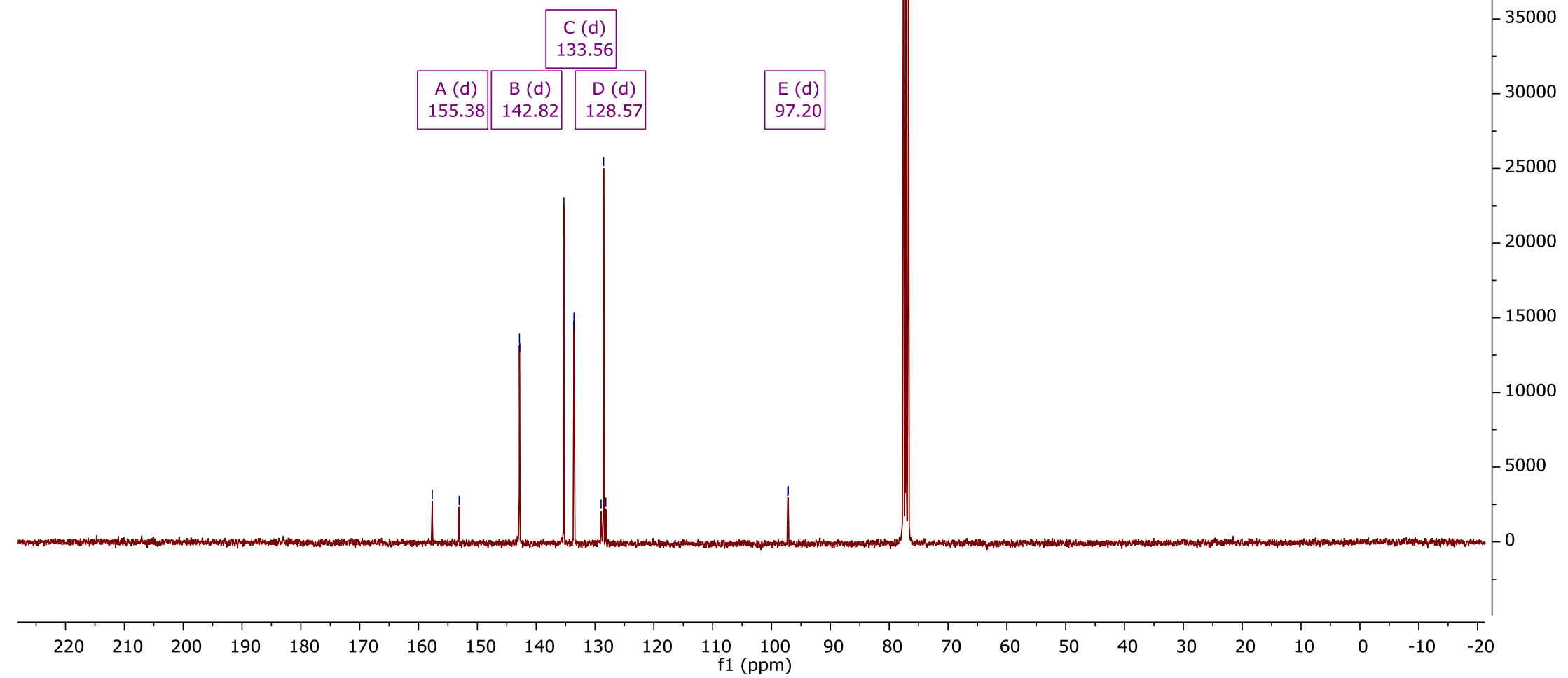
$101\left({ }^{19} \mathrm{~F}\right.$ NMR in $\left.\mathrm{CDCl}_{3}\right)(282 \mathrm{MHz})$

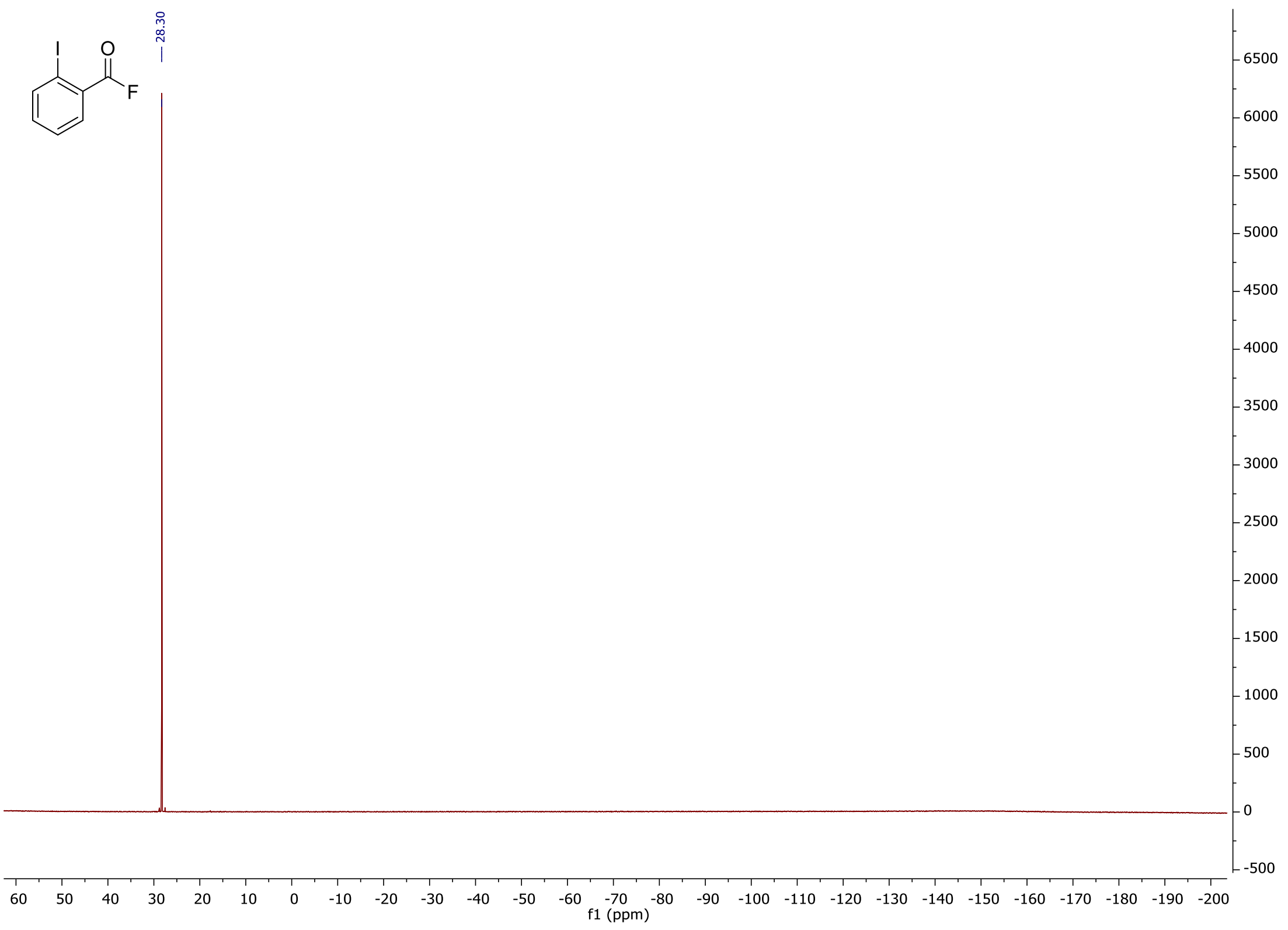


10p $\left({ }^{1} \mathrm{H}\right.$ NMR in $\left.\mathrm{CDCl}_{3}\right)(300 \mathrm{MHz})$

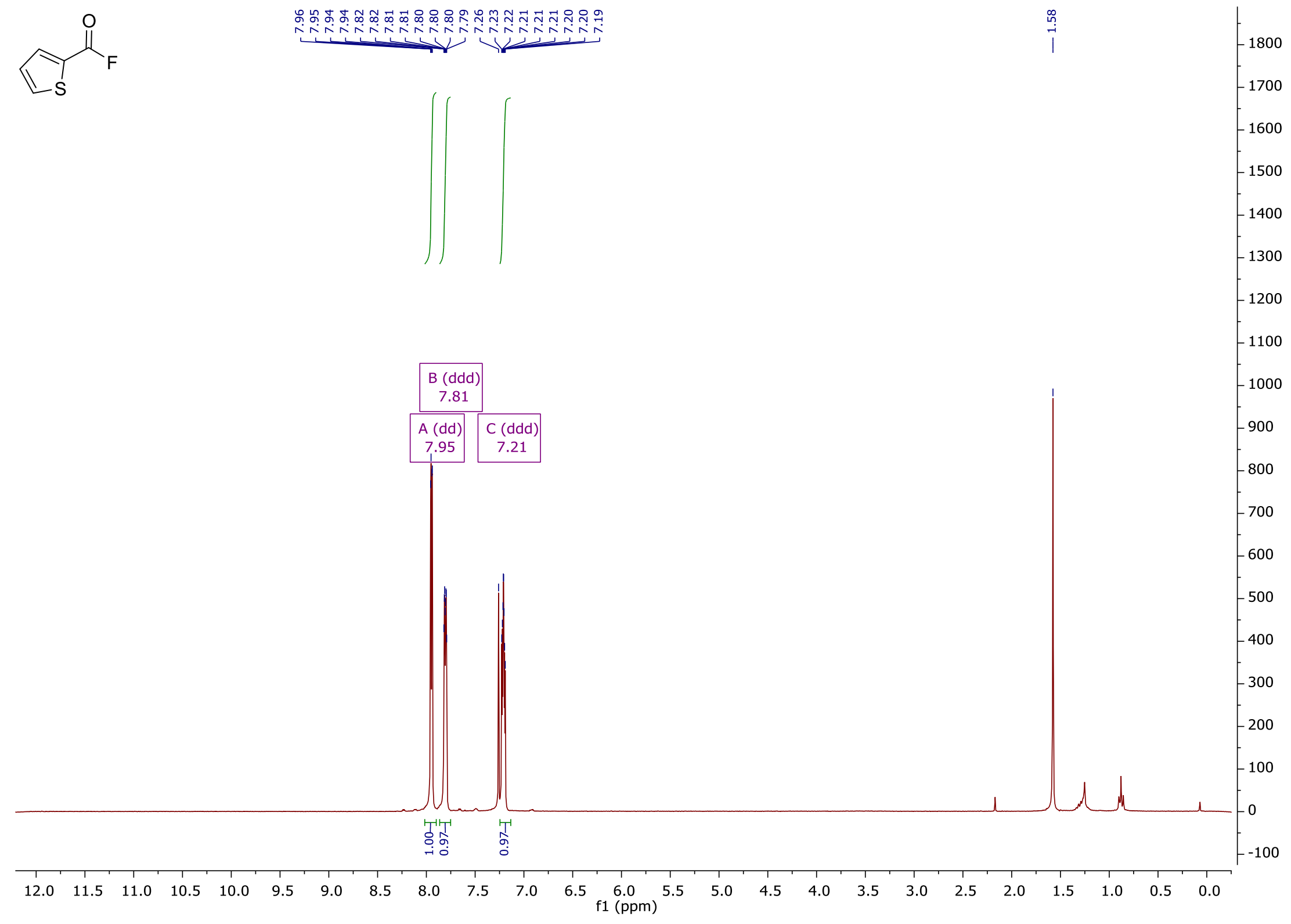


10p $\left({ }^{13} \mathrm{C} \mathrm{NMR}\right.$ in $\left.\mathrm{CDCl}_{3}\right)(75 \mathrm{MHz})$

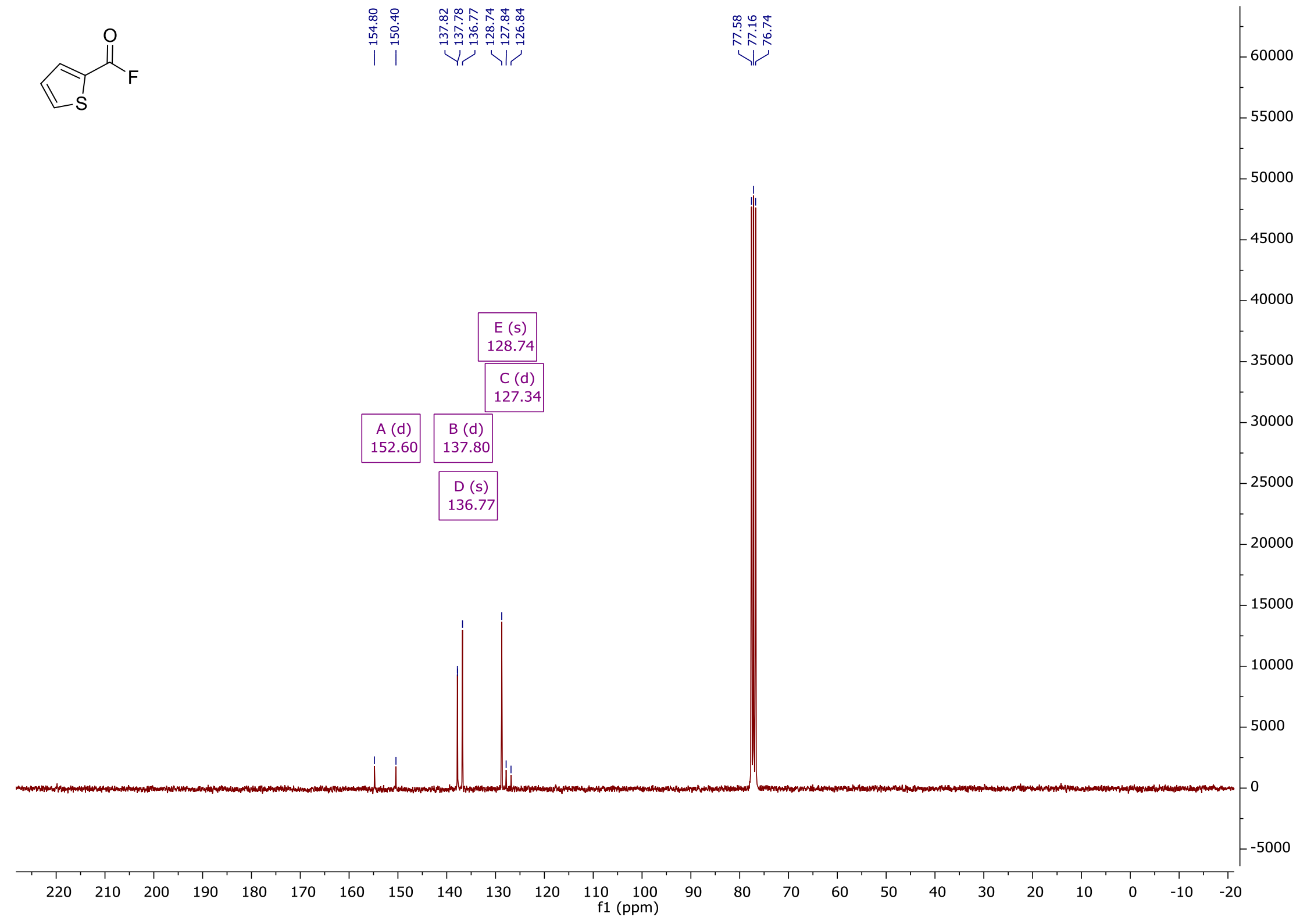




\section{$10 p\left({ }^{19} \mathrm{~F}\right.$ NMR in $\left.\mathrm{CDCl}_{3}\right)(282 \mathrm{MHz})$}

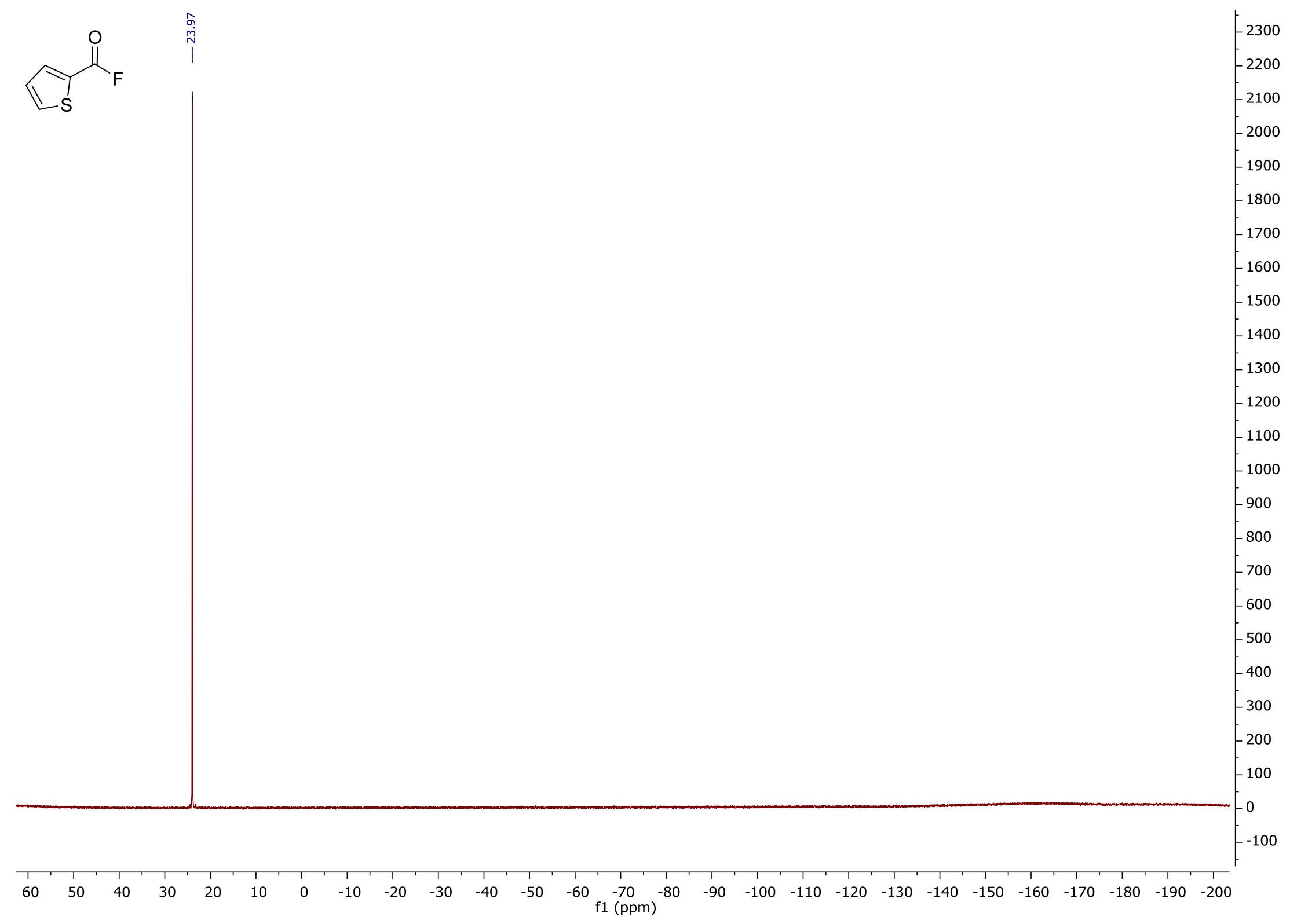


$11\left({ }^{1} \mathrm{H}\right.$ NMR in $\left.\mathrm{CDCl}_{3}\right)(300 \mathrm{MHz})$

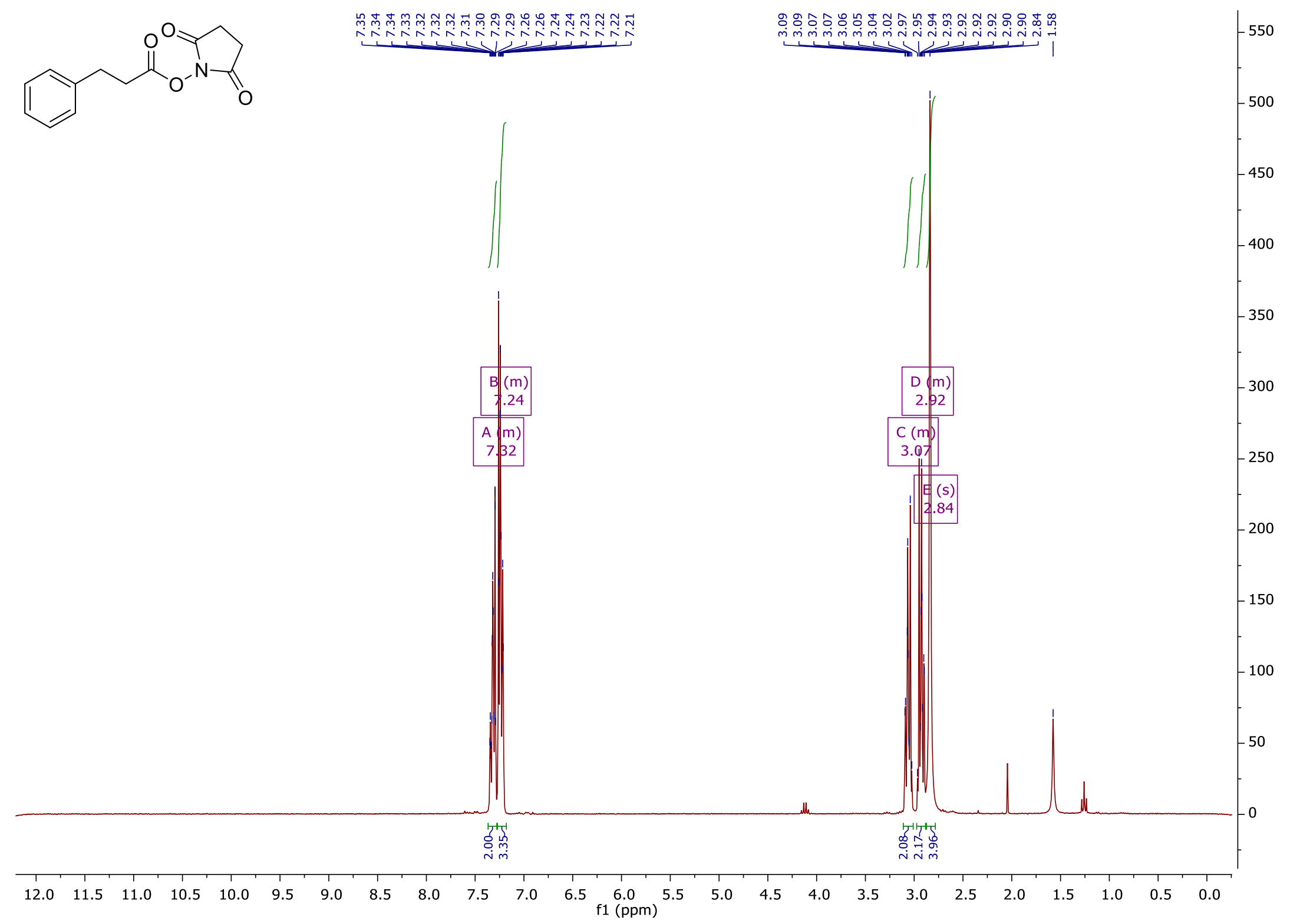


$11\left({ }^{13} \mathrm{C}\right.$ NMR in $\left.\mathrm{CDCl}_{3}\right)(75 \mathrm{MHz})$

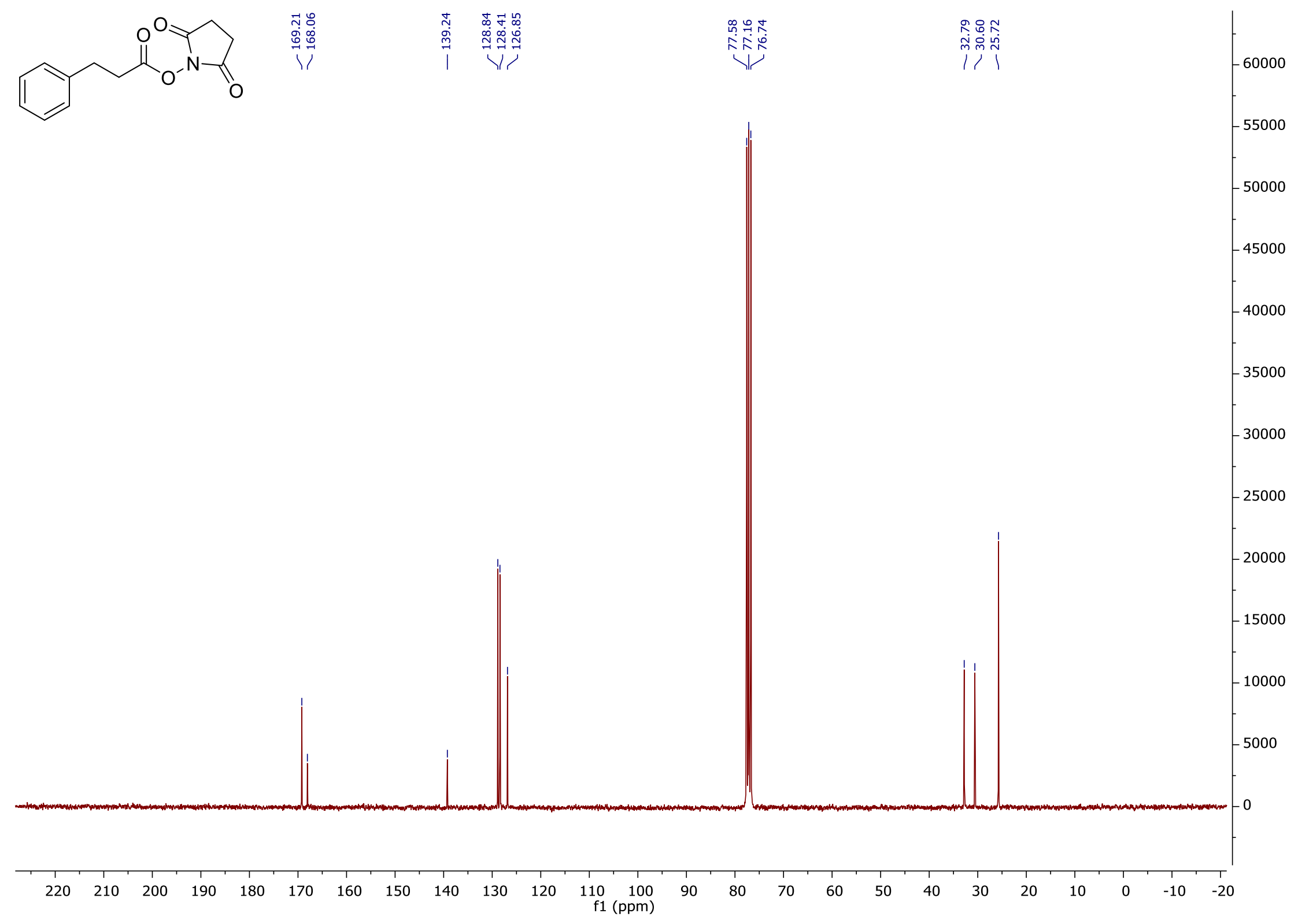


$12\left({ }^{1} \mathrm{H}\right.$ NMR in $\left.\mathrm{CDCl}_{3}\right)(300 \mathrm{MHz})$

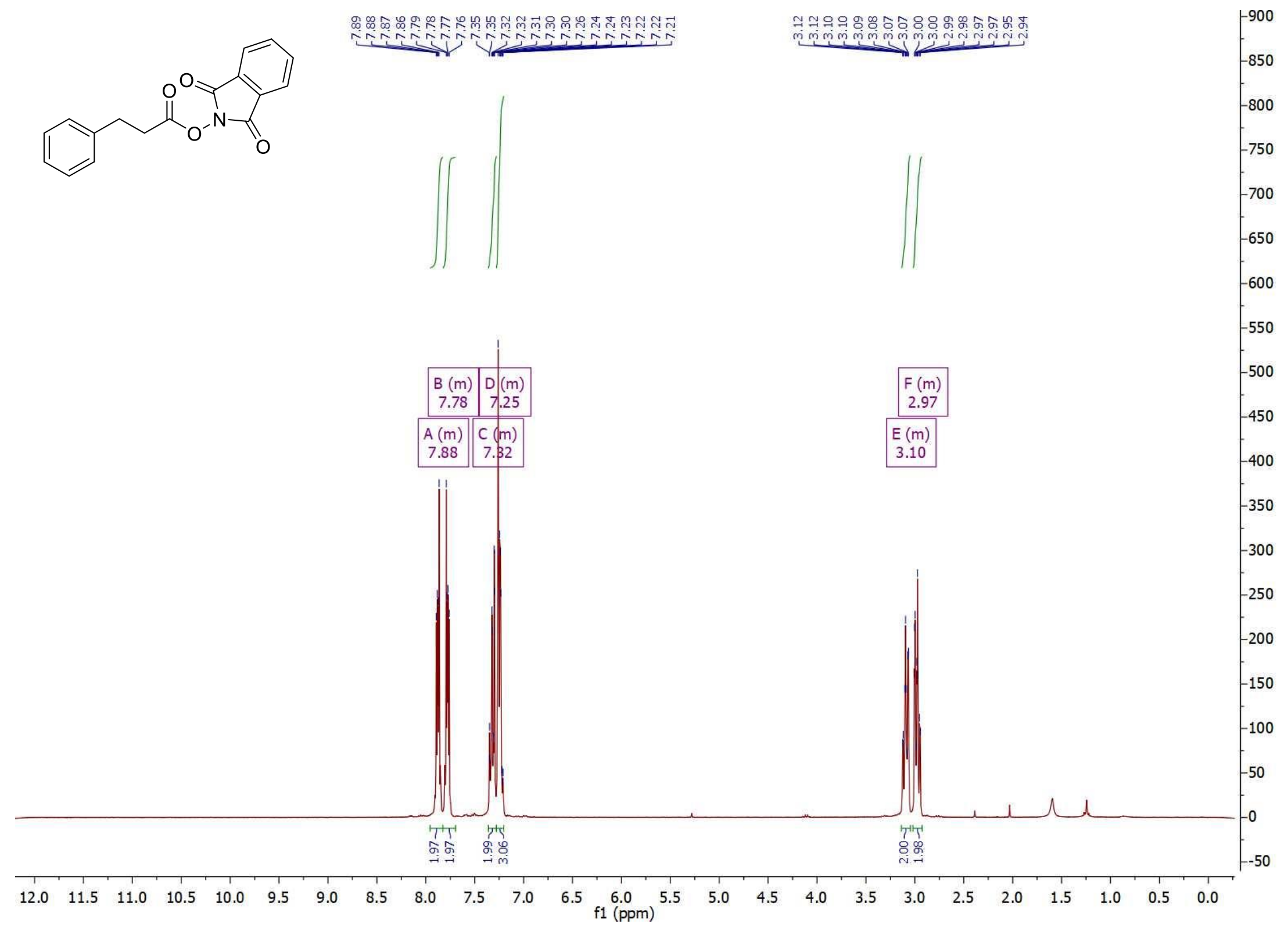


$12\left({ }^{13} \mathrm{C} \mathrm{NMR}\right.$ in $\left.\mathrm{CDCl}_{3}\right)(75 \mathrm{MHz})$

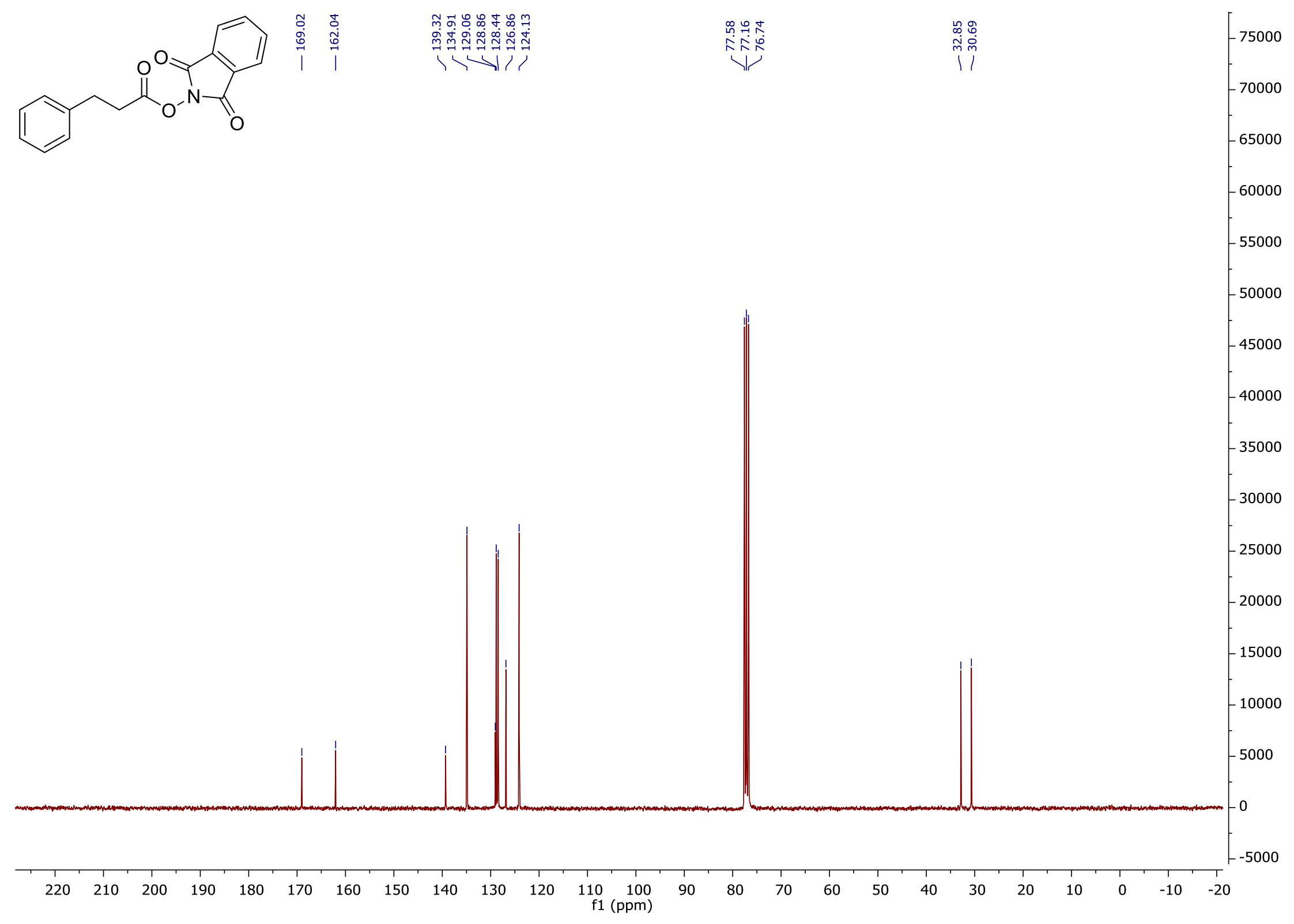


$13\left({ }^{1} \mathrm{H}\right.$ NMR in $\left.\mathrm{CDCl}_{3}\right)(300 \mathrm{MHz})$

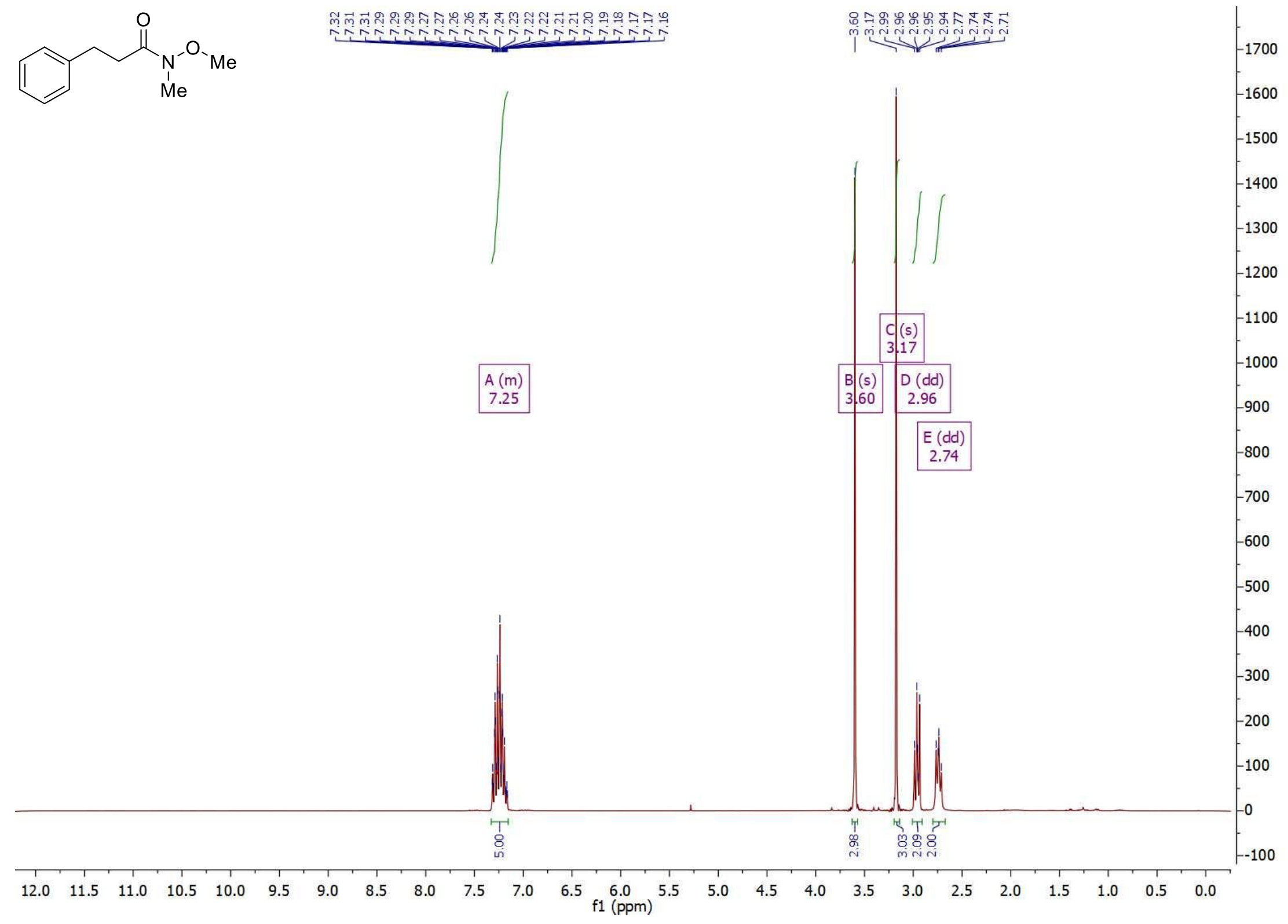


$13\left({ }^{13} \mathrm{C}\right.$ NMR in $\left.\mathrm{CDCl}_{3}\right)(75 \mathrm{MHz})$

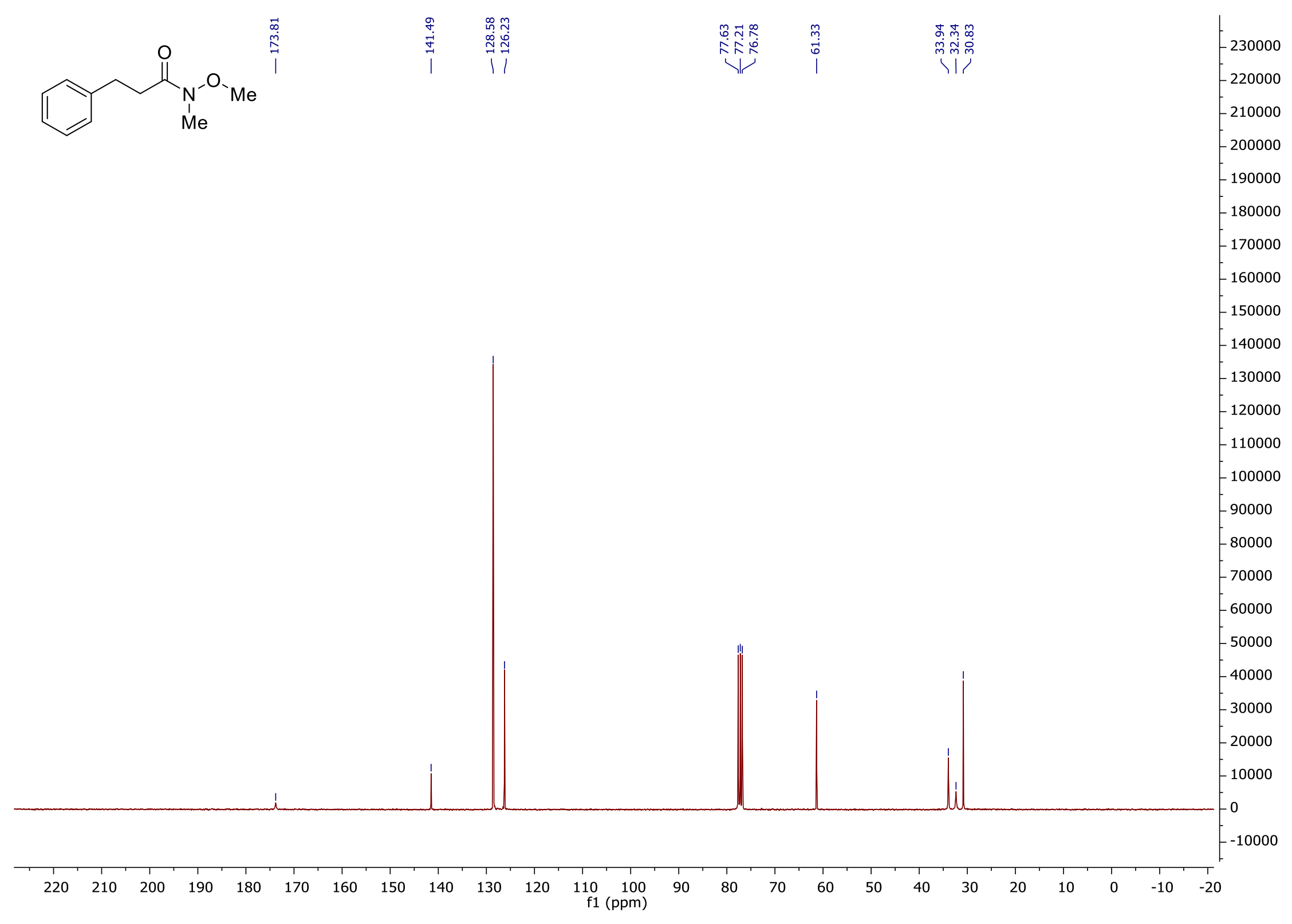


$14\left({ }^{1} \mathrm{H}\right.$ NMR in $\left.\mathrm{CDCl}_{3}\right)(300 \mathrm{MHz})$

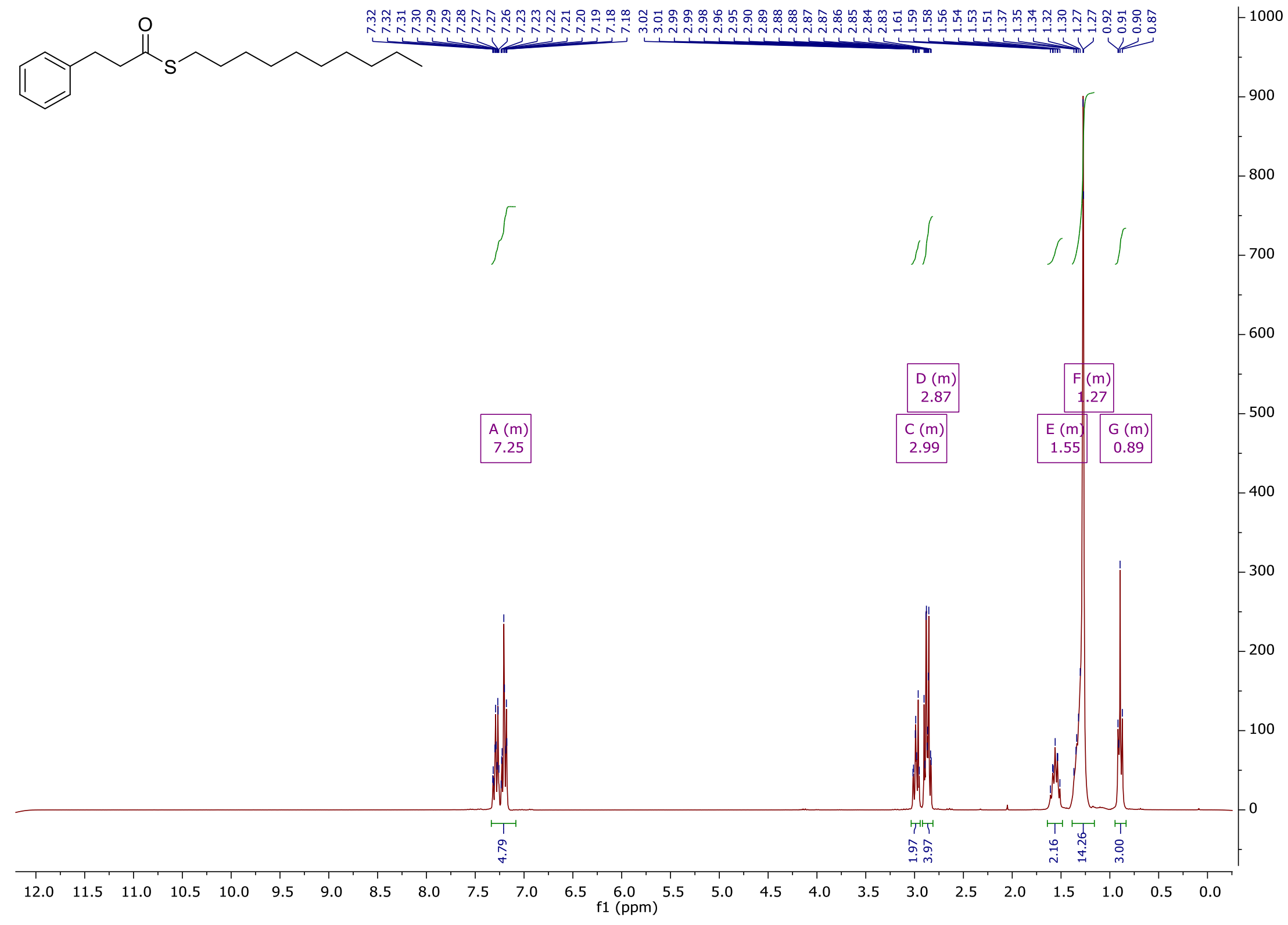


$14\left({ }^{13} \mathrm{C}\right.$ NMR in $\left.\mathrm{CDCl}_{3}\right)(75 \mathrm{MHz})$

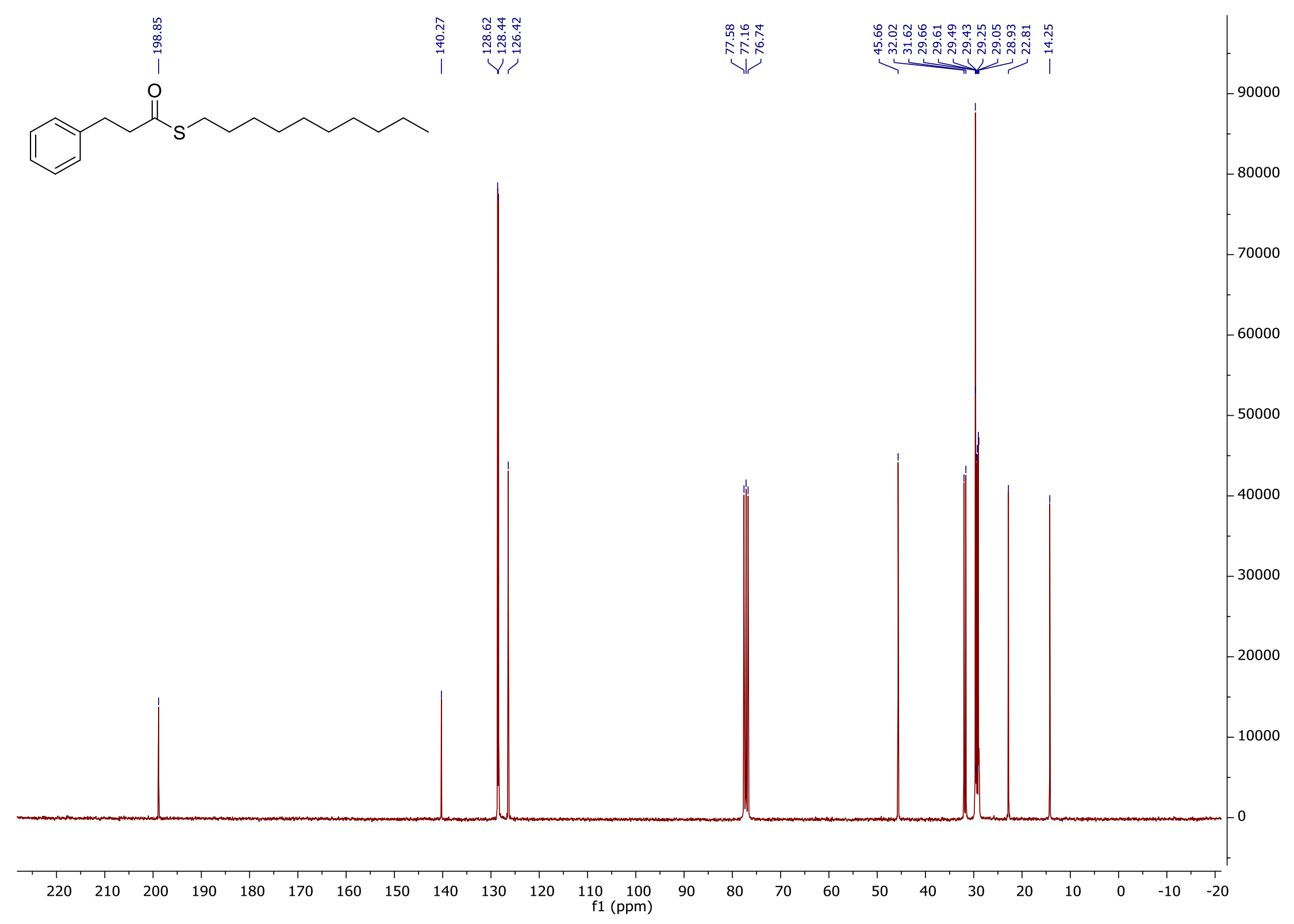


$15\left({ }^{1} \mathrm{H}\right.$ NMR in $\left.\mathrm{CDCl}_{3}\right)(300 \mathrm{MHz})$

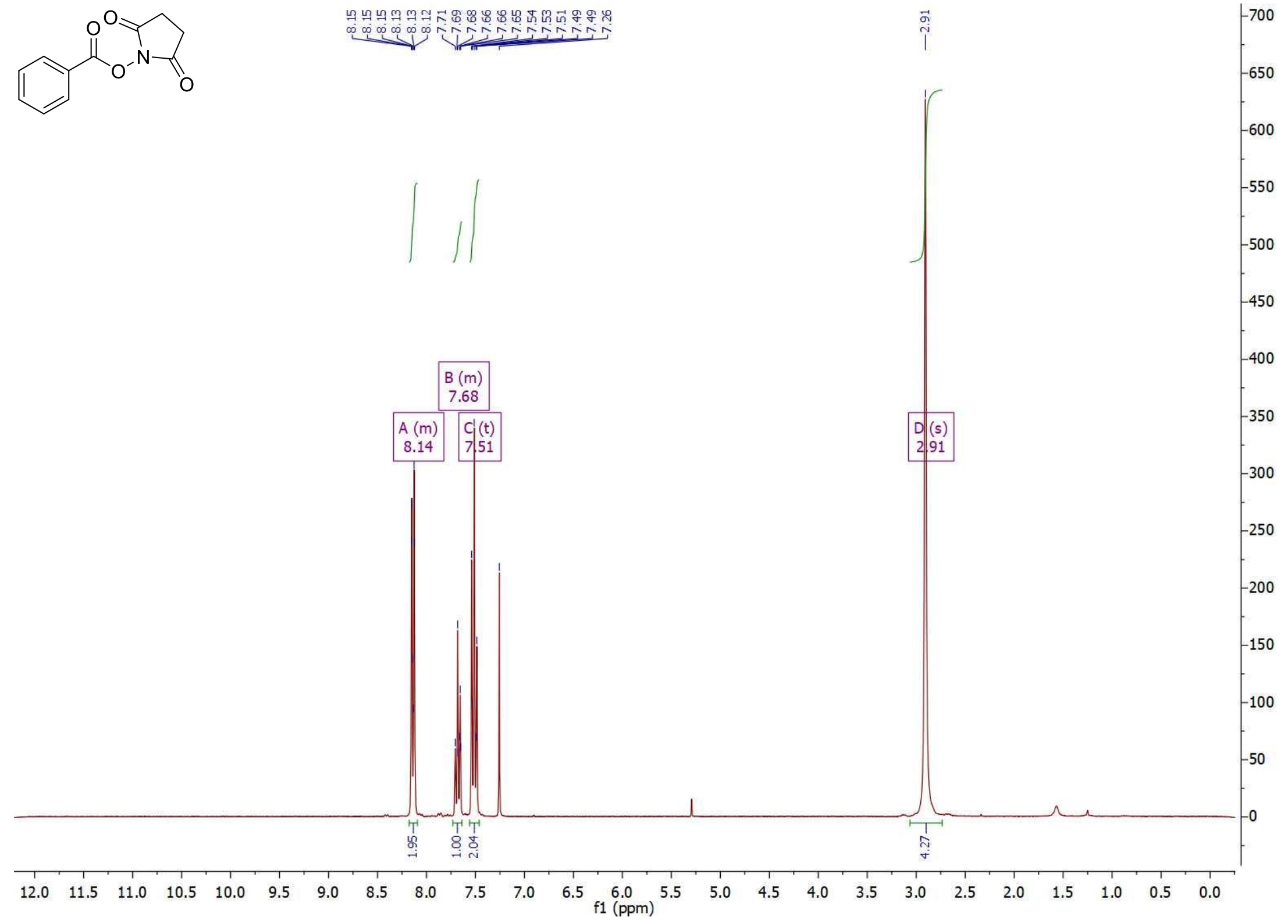


$15\left({ }^{13} \mathrm{C} \mathrm{NMR}\right.$ in $\left.\mathrm{CDCl}_{3}\right)(75 \mathrm{MHz})$

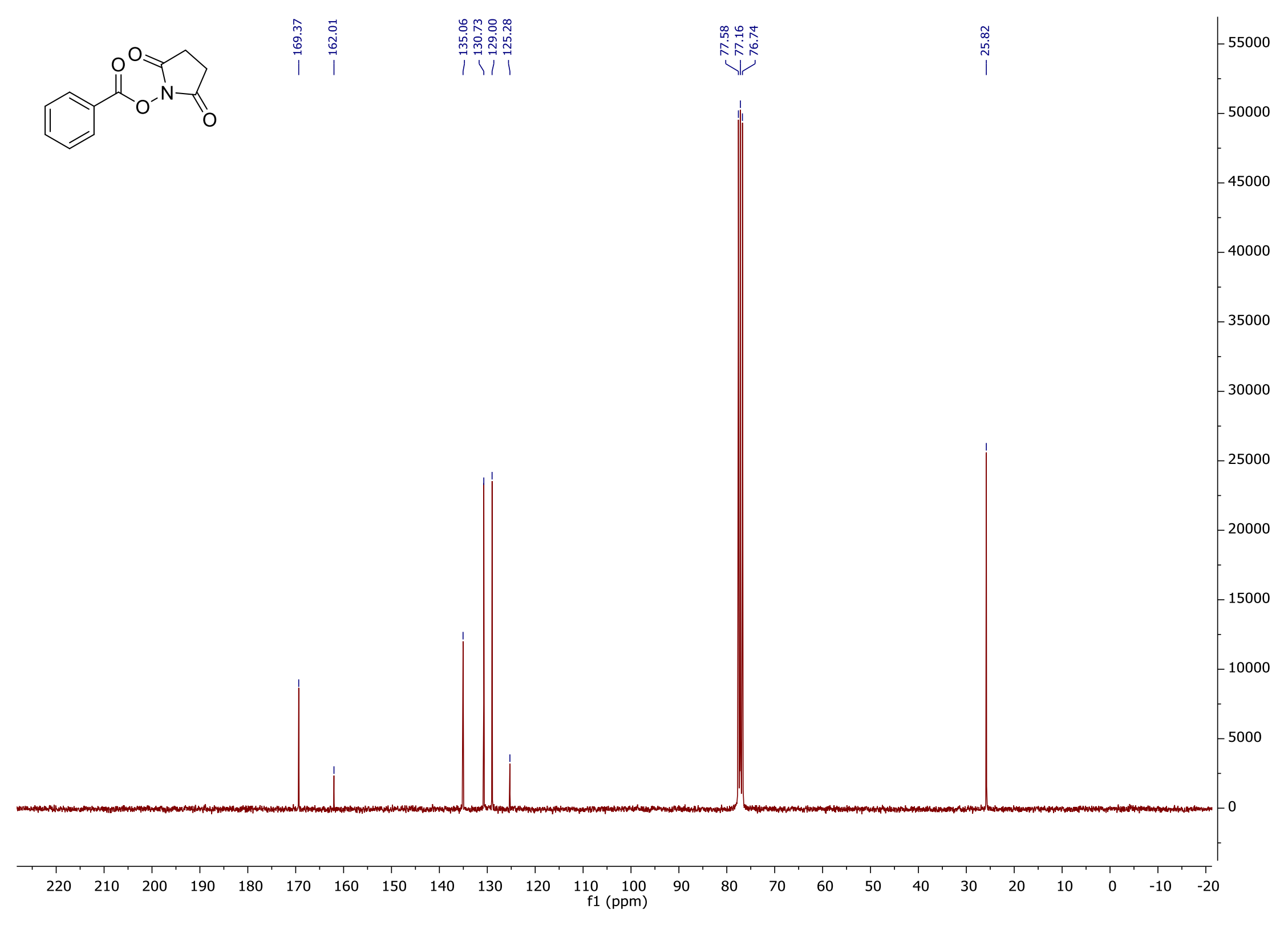


$16\left({ }^{1} \mathrm{H}\right.$ NMR in $\left.\mathrm{CDCl}_{3}\right)(300 \mathrm{MHz})$

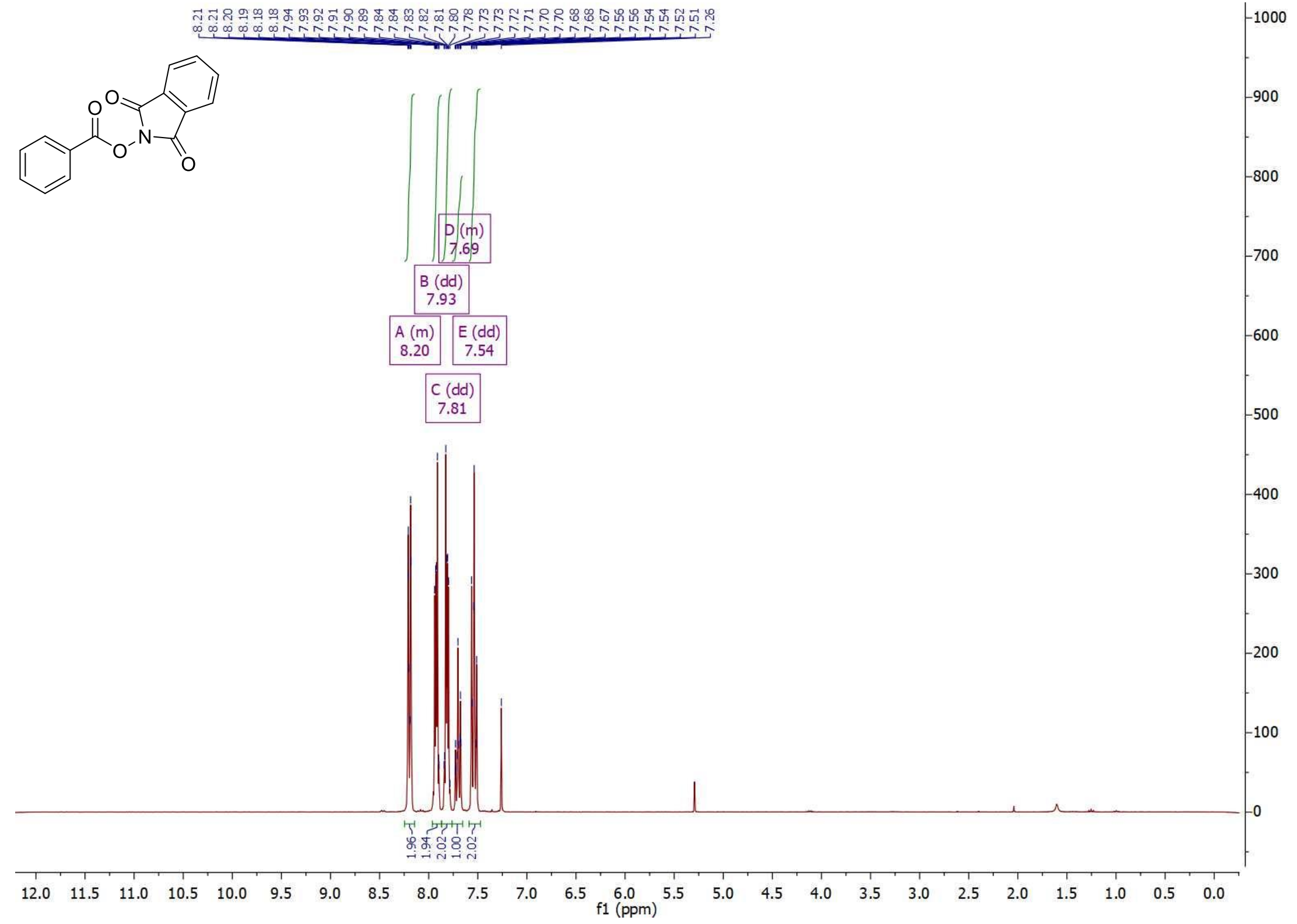


$16\left({ }^{13} \mathrm{C} \mathrm{NMR}\right.$ in $\left.\mathrm{CDCl}_{3}\right)(75 \mathrm{MHz})$

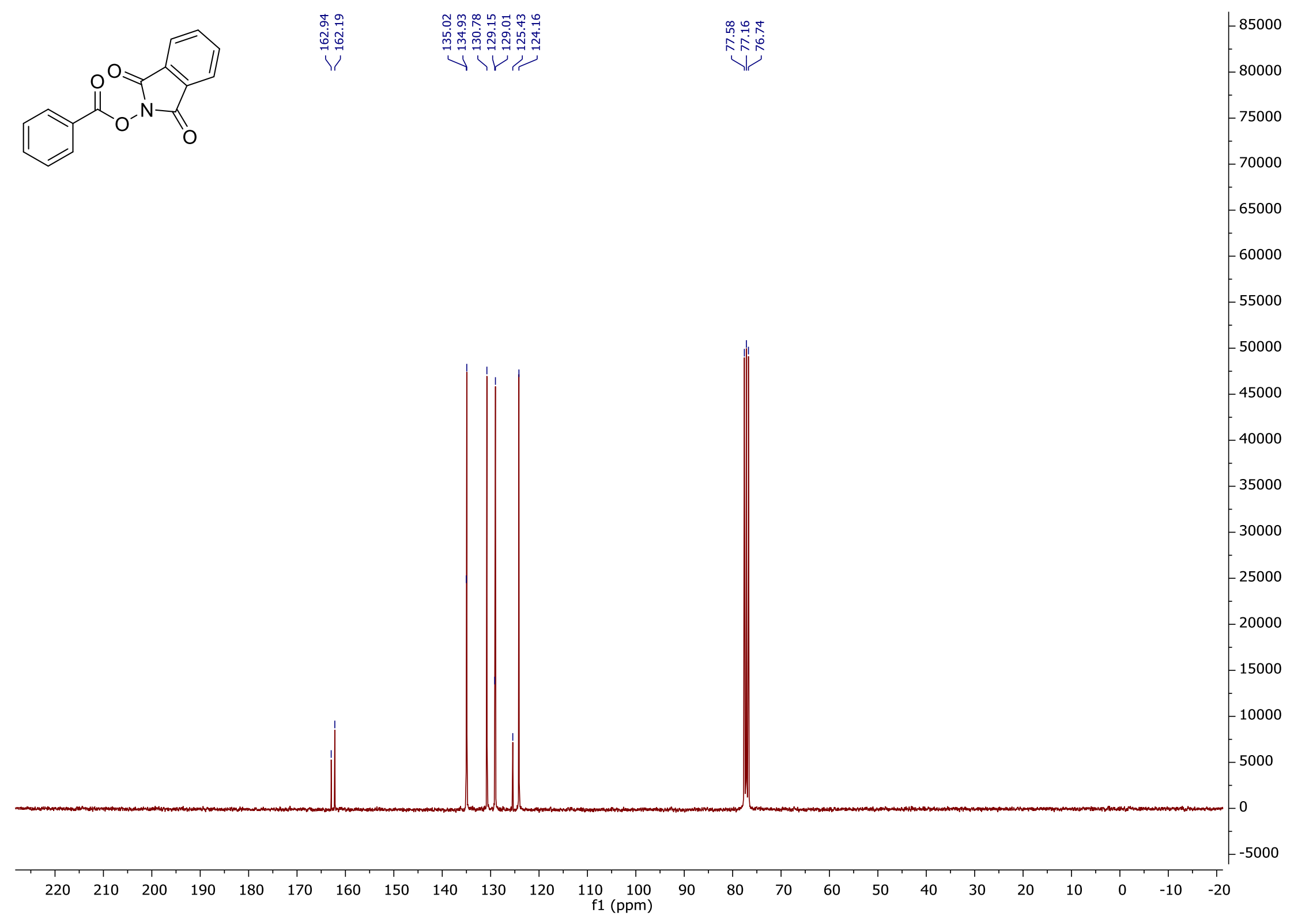


$17\left({ }^{1} \mathrm{H}\right.$ NMR in $\left.\mathrm{CDCl}_{3}\right)(300 \mathrm{MHz})$

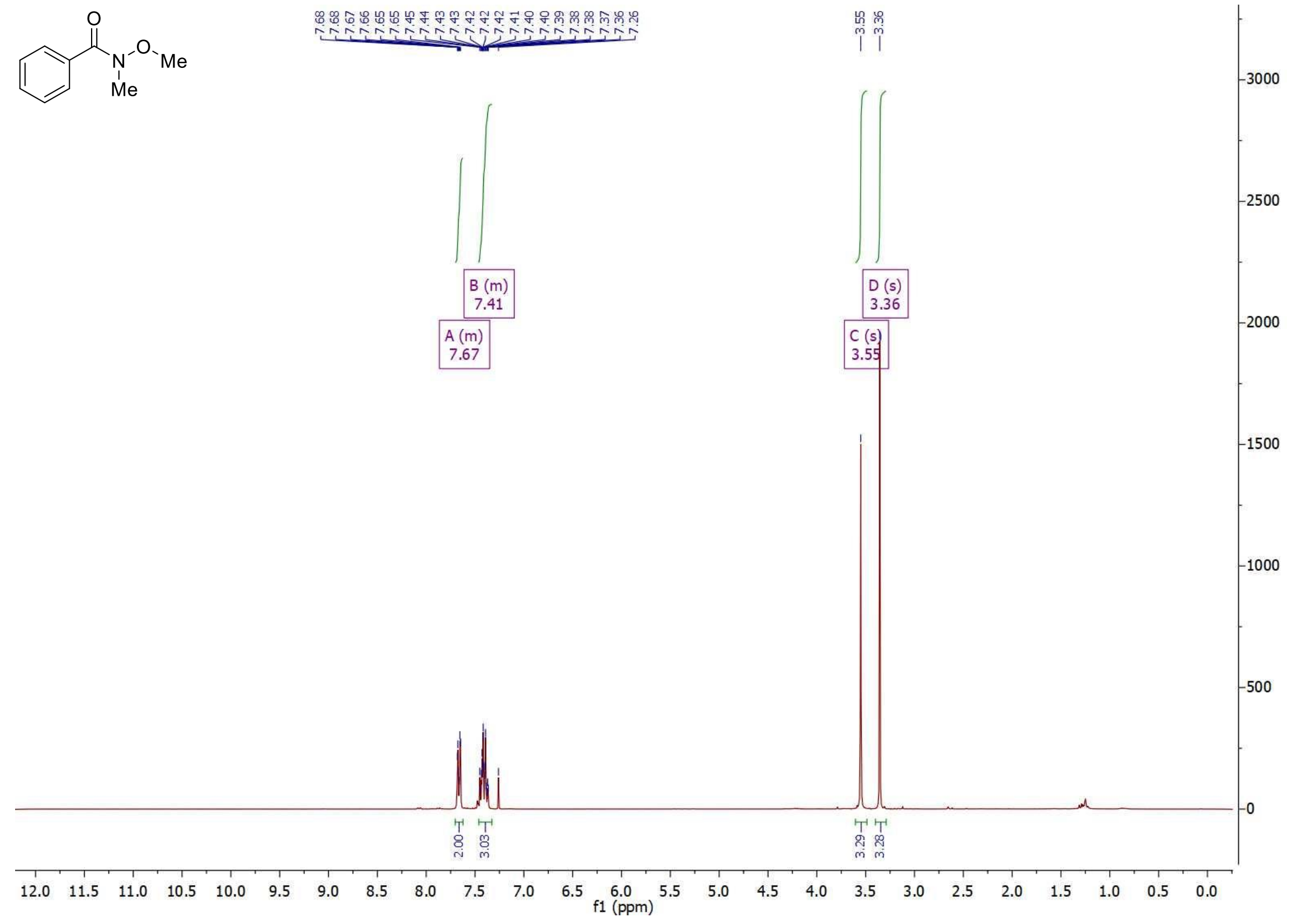


$17\left({ }^{13} \mathrm{C} \mathrm{NMR}\right.$ in $\left.\mathrm{CDCl}_{3}\right)(75 \mathrm{MHz})$

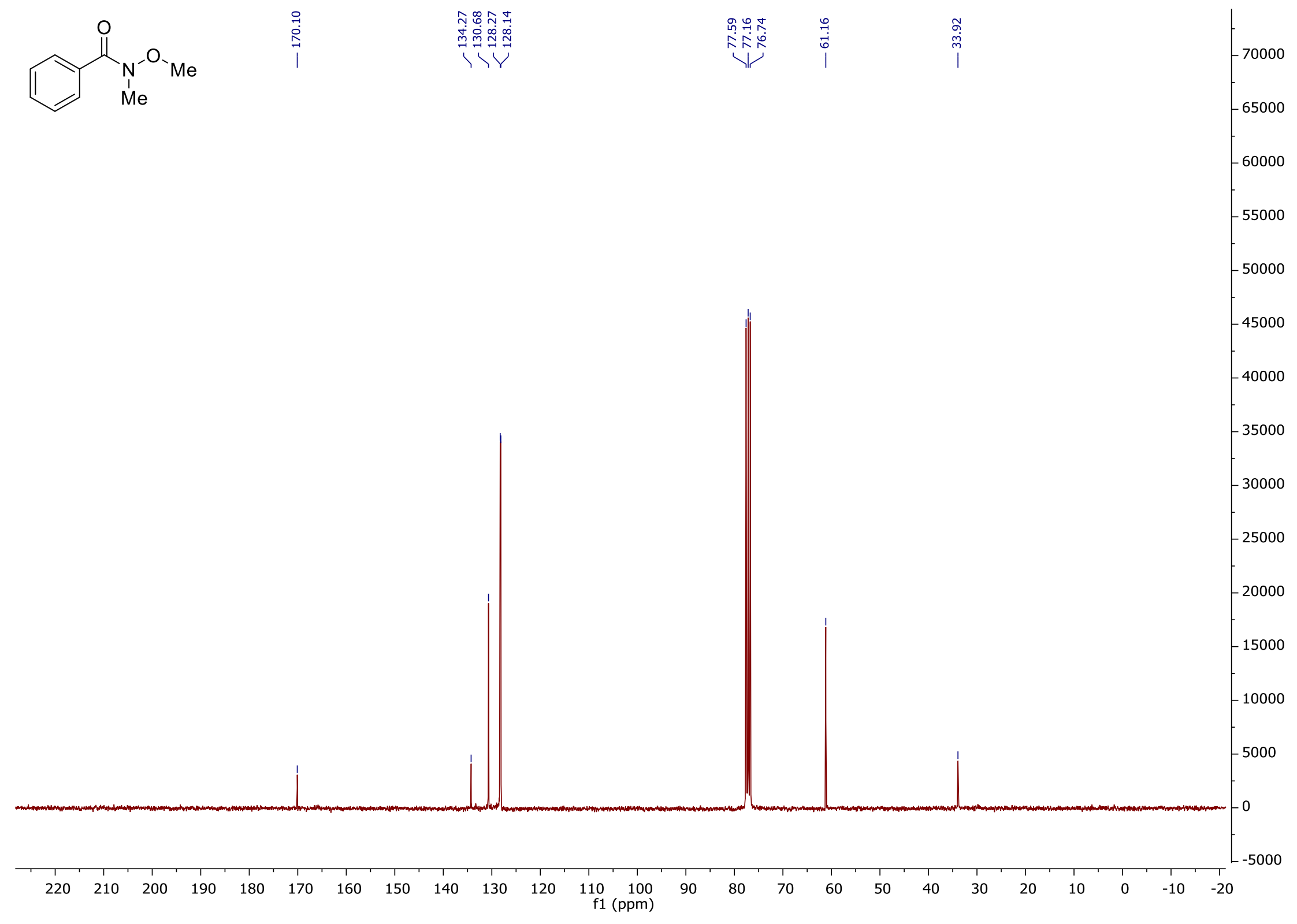


$18\left({ }^{1} \mathrm{H}\right.$ NMR in $\left.\mathrm{CDCl}_{3}\right)(300 \mathrm{MHz})$

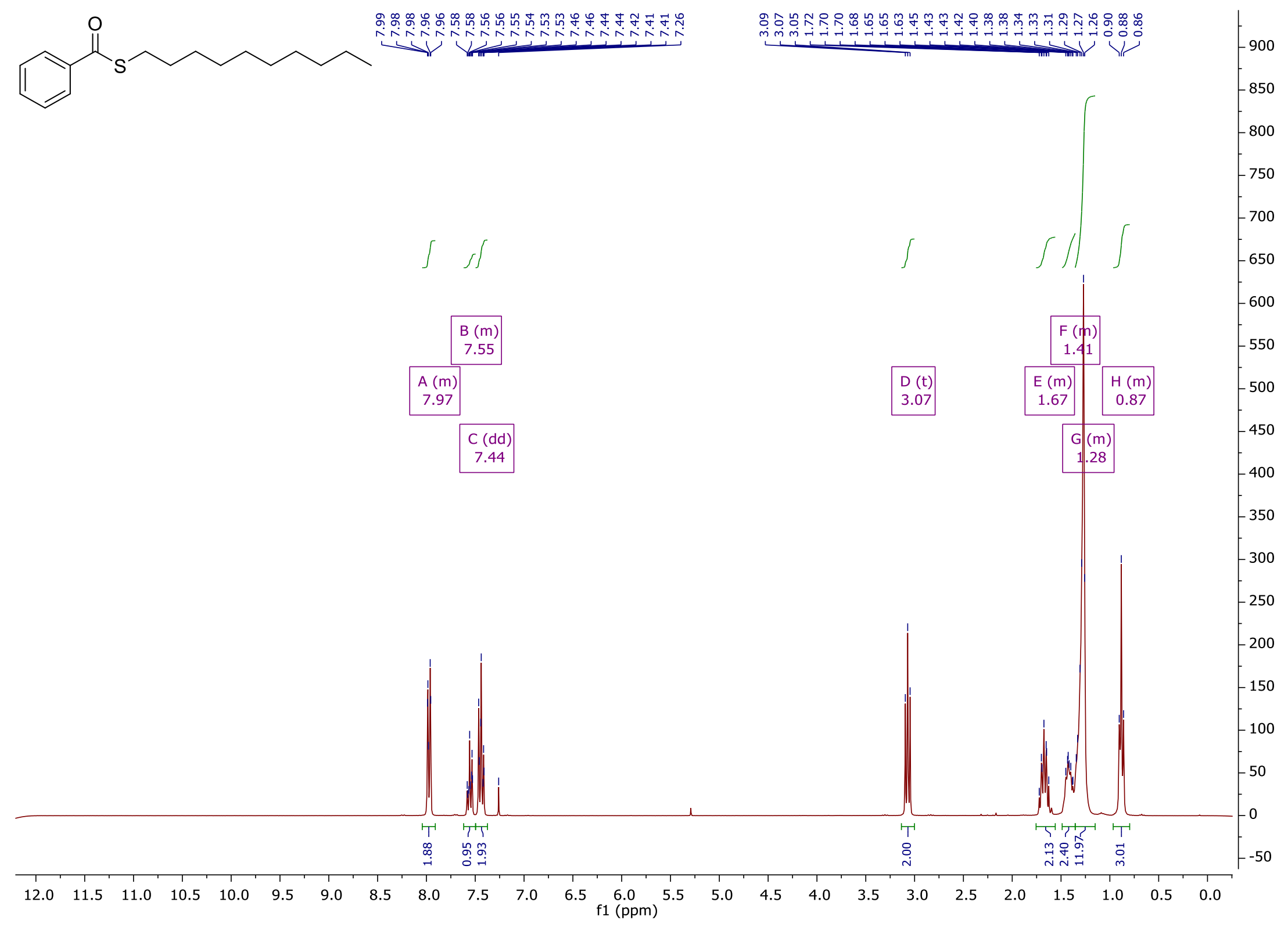


$18\left({ }^{13} \mathrm{C}\right.$ NMR in $\left.\mathrm{CDCl}_{3}\right)(75 \mathrm{MHz})$

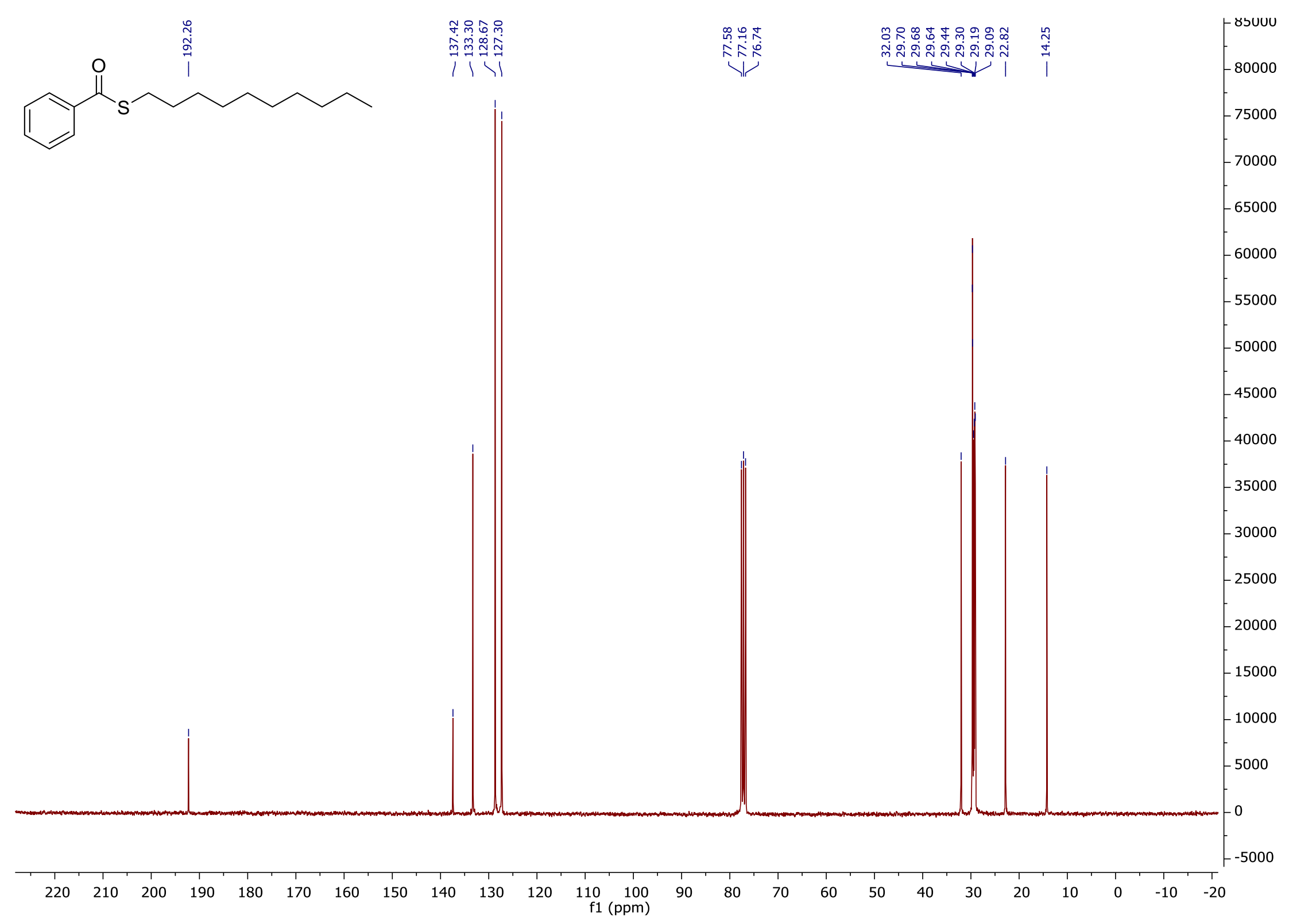


S1 $\left({ }^{1} \mathrm{H}\right.$ NMR in $\left.\mathrm{CDCl}_{3}\right)(300 \mathrm{MHz})$

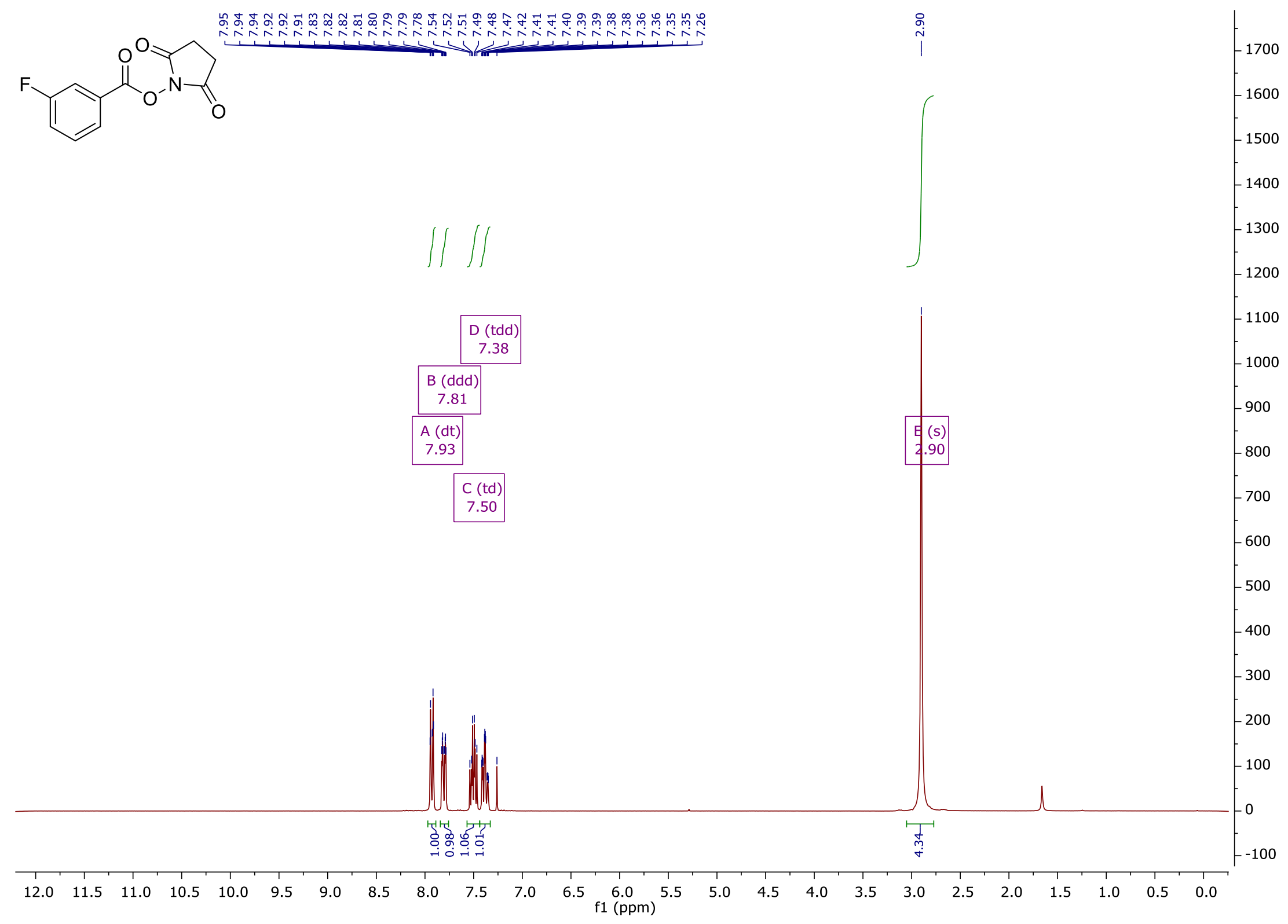


$\mathrm{S} 1\left({ }^{13} \mathrm{C}\right.$ NMR in $\left.\mathrm{CDCl}_{3}\right)(75 \mathrm{MHz})$

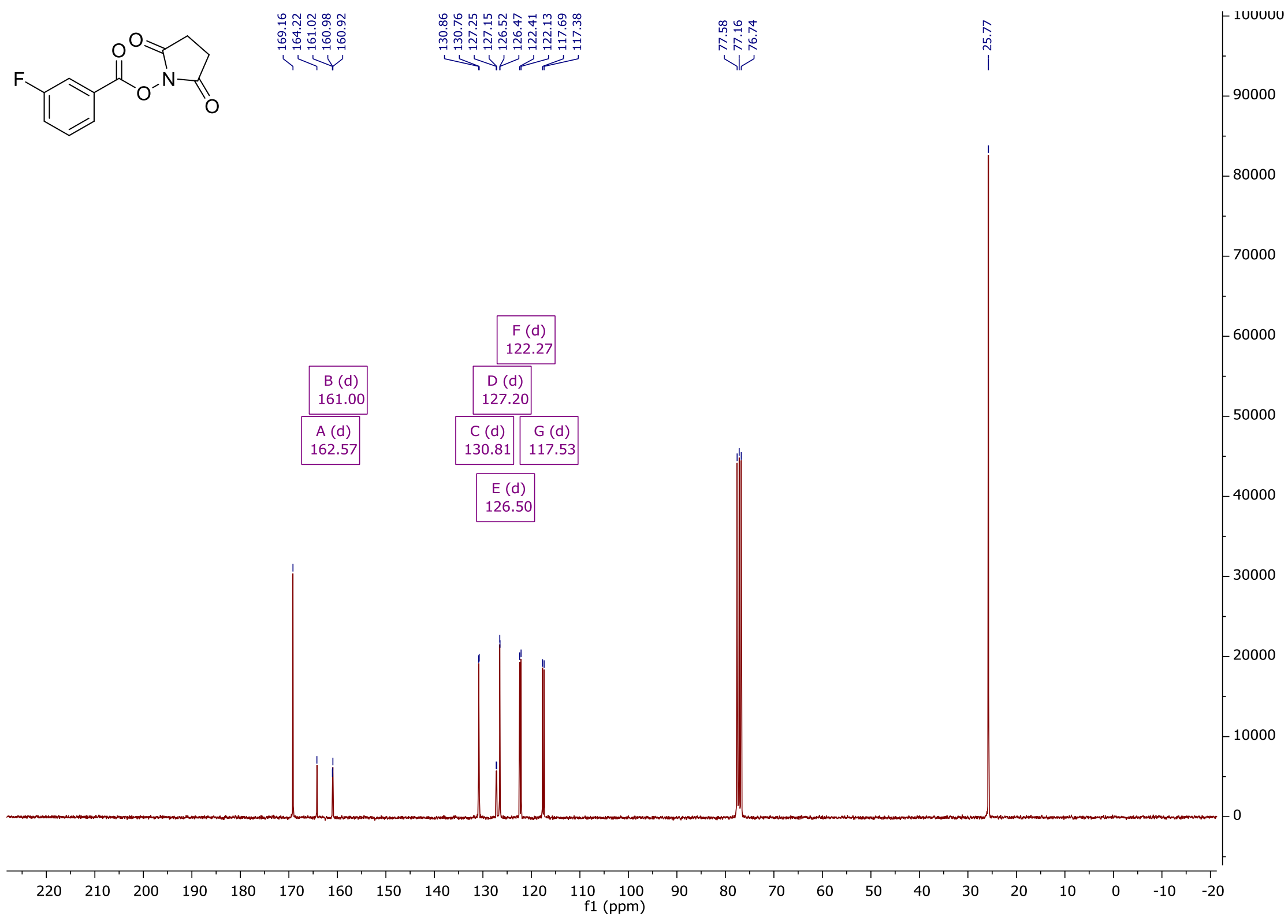


$\mathrm{S} 2\left({ }^{1} \mathrm{H}\right.$ NMR in $\left.\mathrm{CDCl}_{3}\right)(300 \mathrm{MHz})$

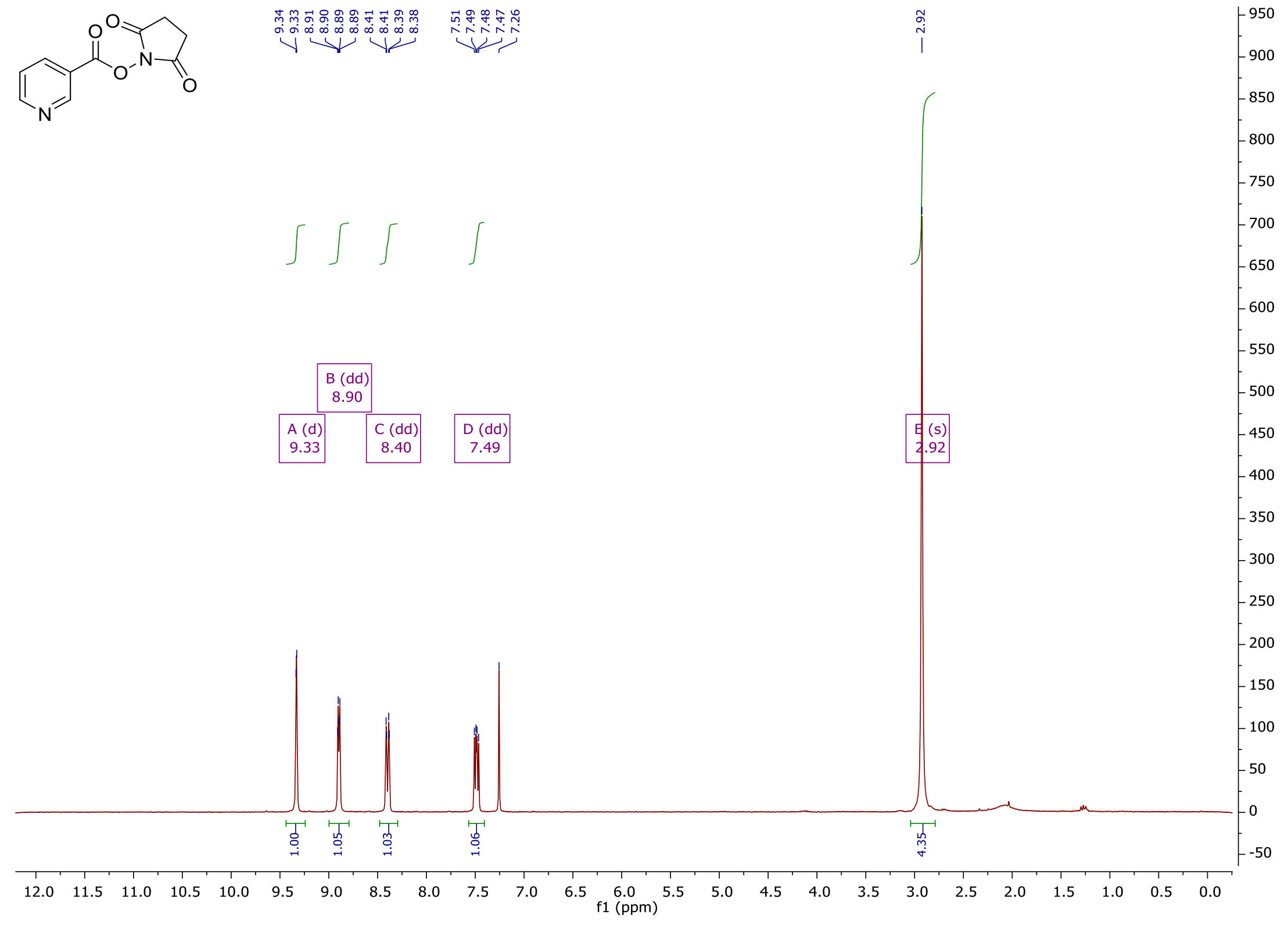


S2 $\left({ }^{13} \mathrm{C}\right.$ NMR in $\left.\mathrm{CDCl}_{3}\right)(75 \mathrm{MHz})$

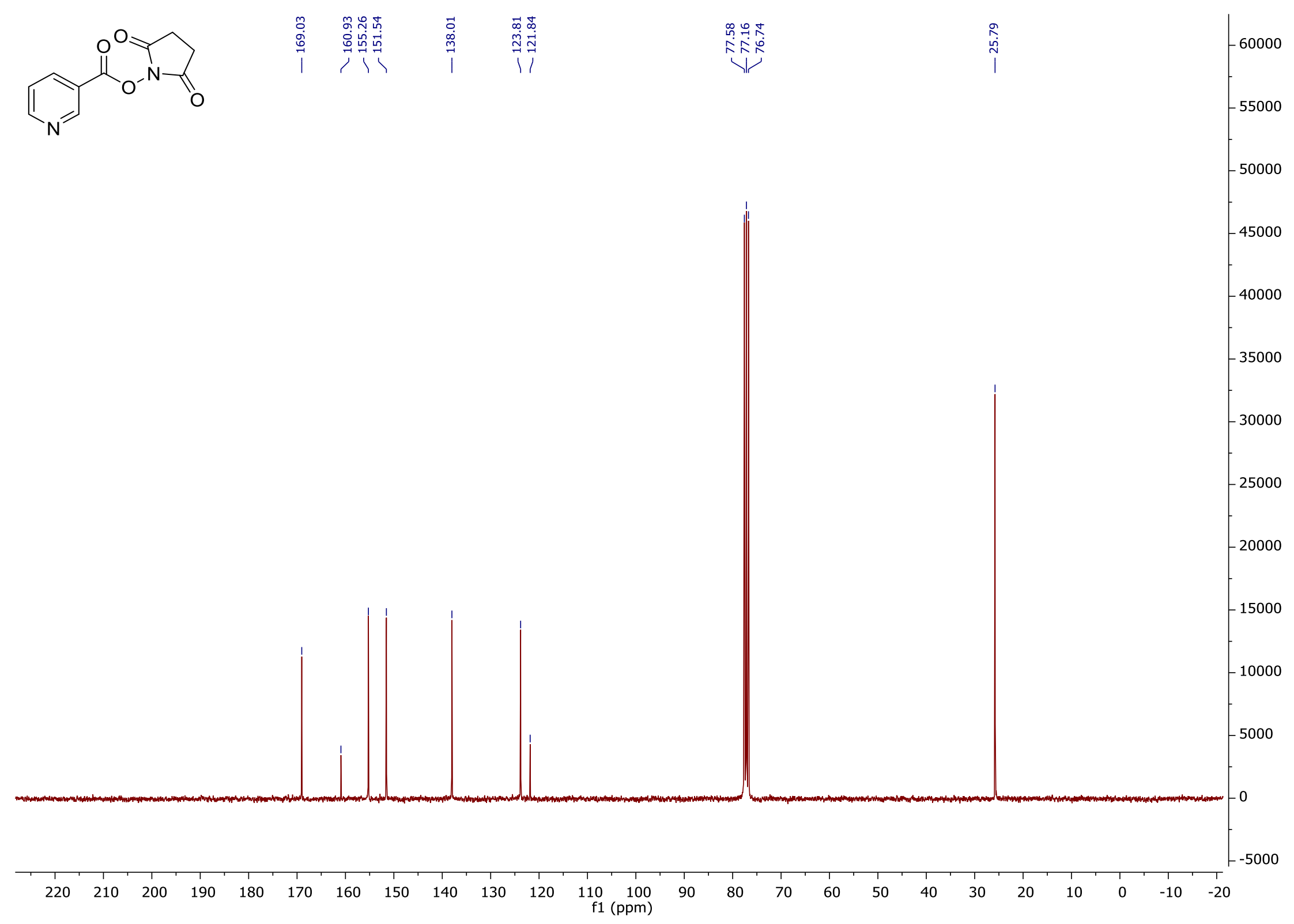


S3 $\left({ }^{1} \mathrm{H}\right.$ NMR in $\left.\mathrm{CDCl}_{3}\right)(300 \mathrm{MHz})$
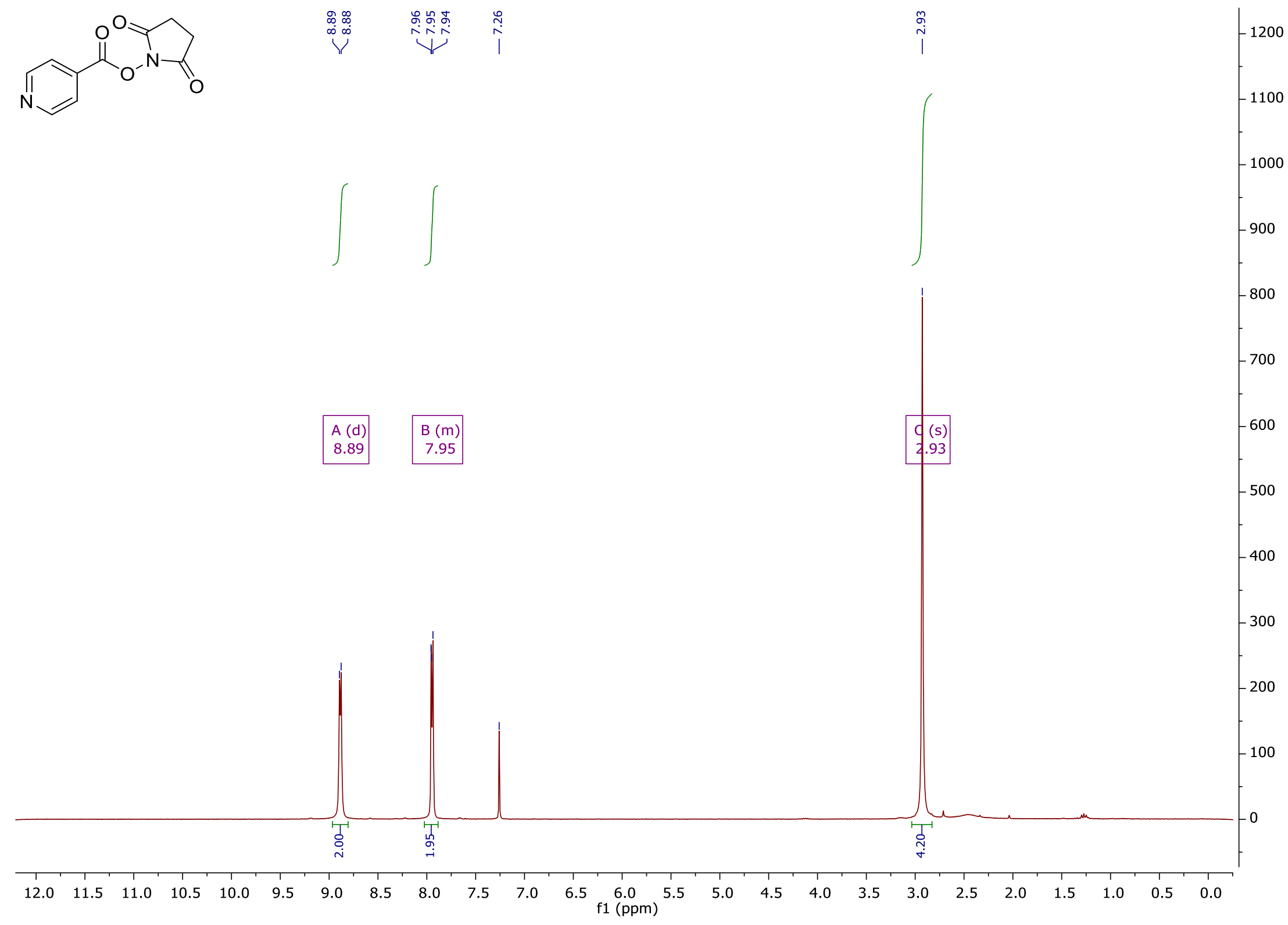


\section{$\mathrm{S3}\left({ }^{13} \mathrm{C} \mathrm{NMR}\right.$ in $\left.\mathrm{CDCl}_{3}\right)(75 \mathrm{MHz})$}

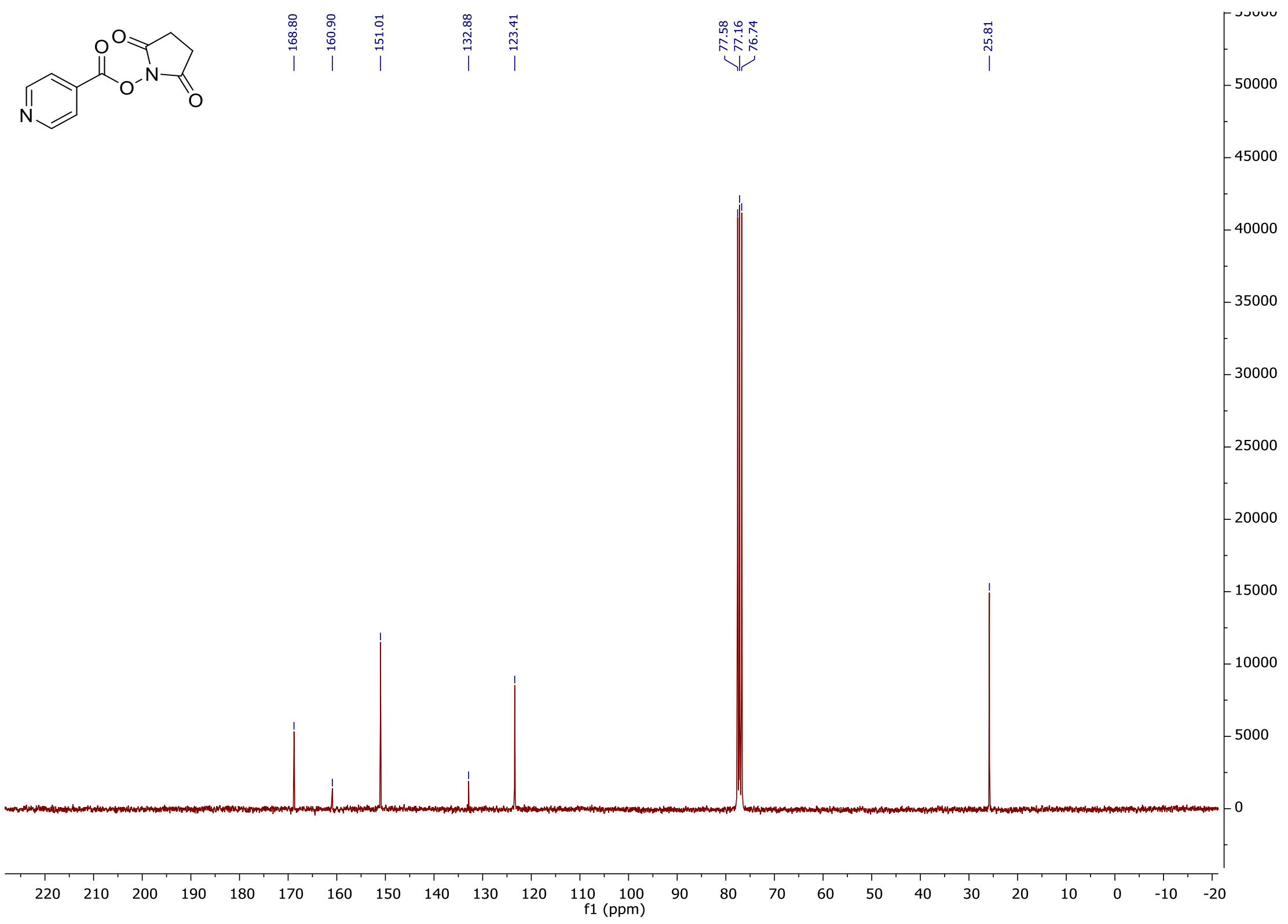


S4 $\left({ }^{1} \mathrm{H}\right.$ NMR in $\left.\mathrm{CDCl}_{3}\right)(300 \mathrm{MHz})$

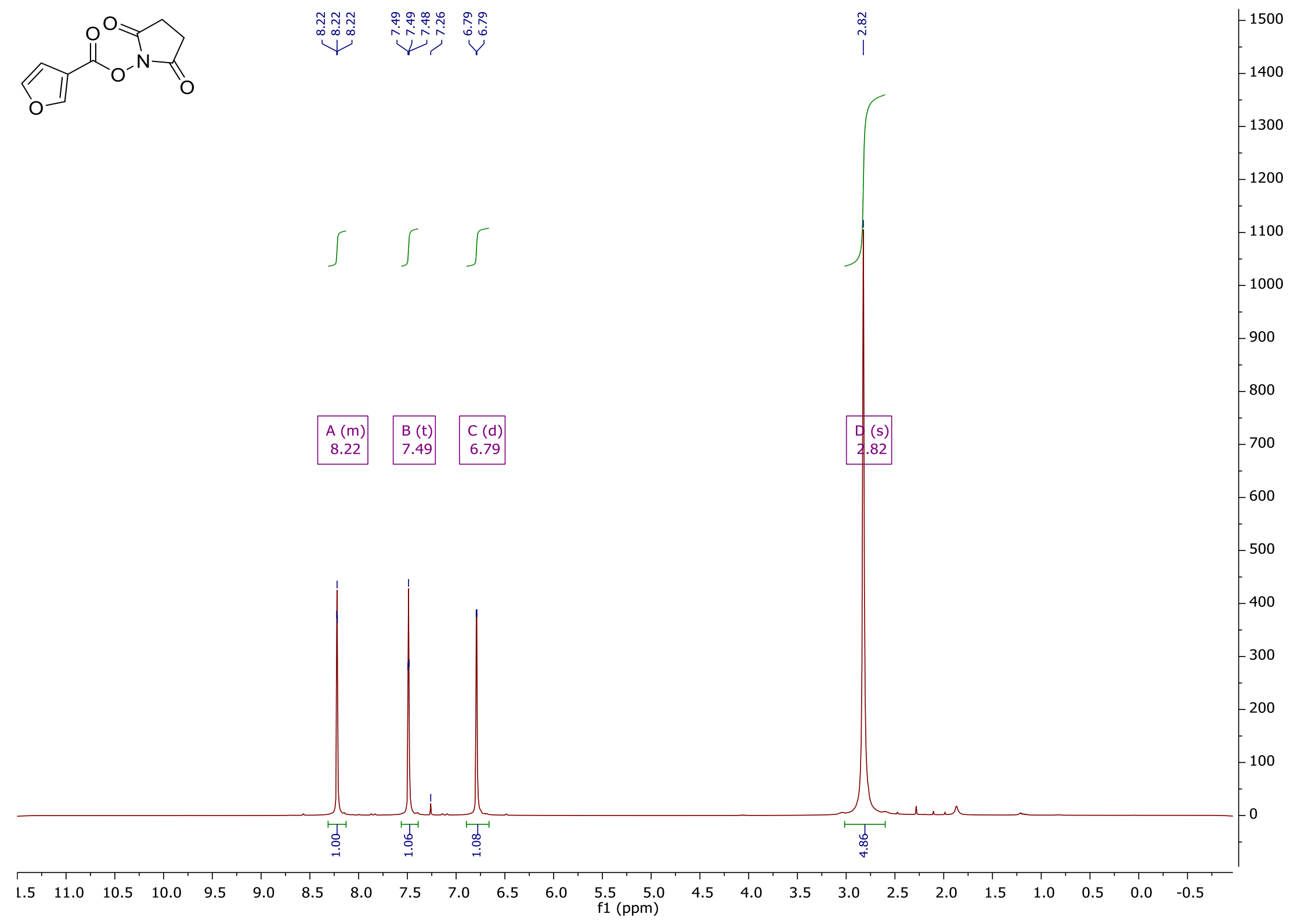




\section{S4 $\left({ }^{13} \mathrm{C}\right.$ NMR in $\left.\mathrm{CDCl}_{3}\right)(75 \mathrm{MHz})$}

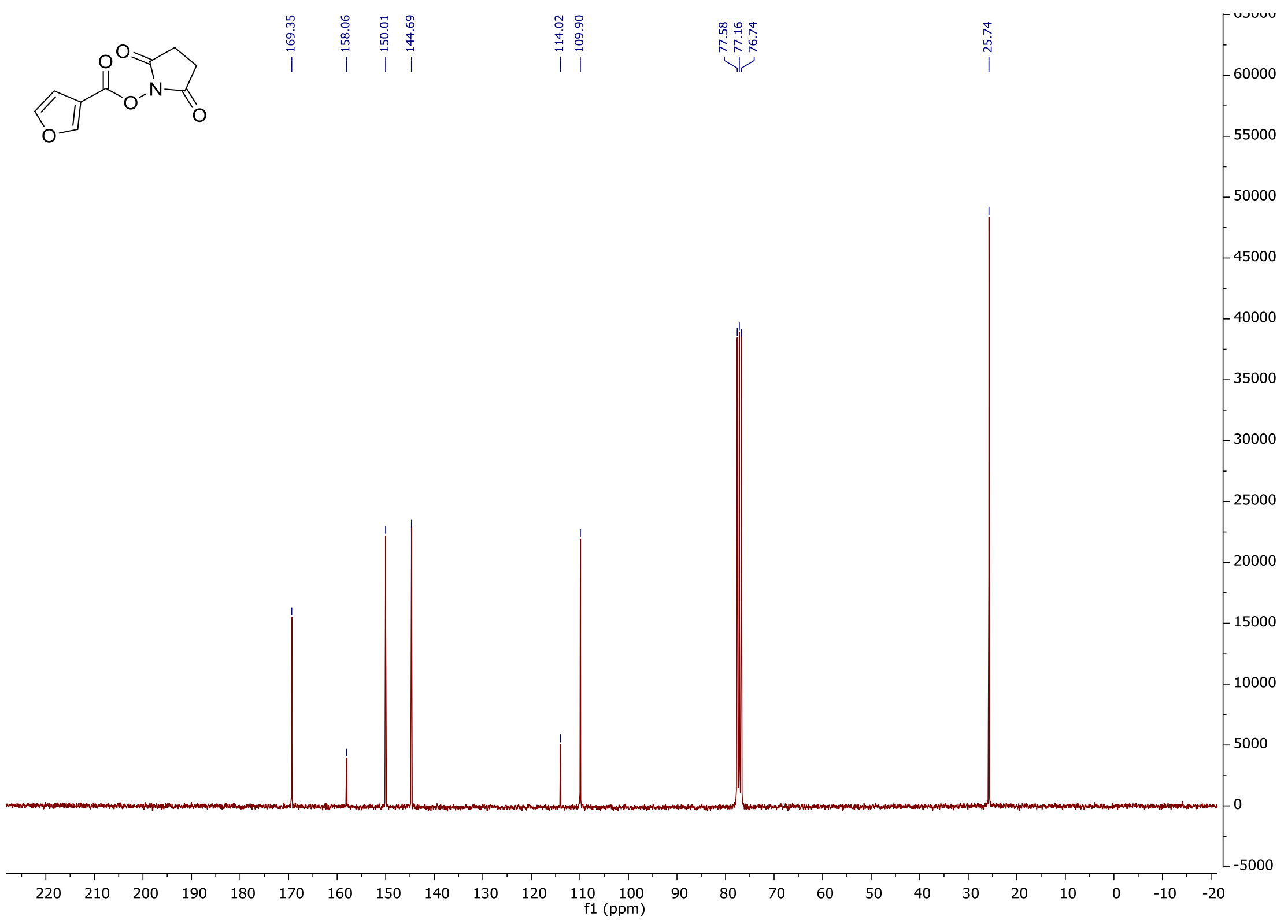


S5 $\left({ }^{1} \mathrm{H}\right.$ NMR in $\left.\mathrm{CDCl}_{3}\right)(300 \mathrm{MHz})$

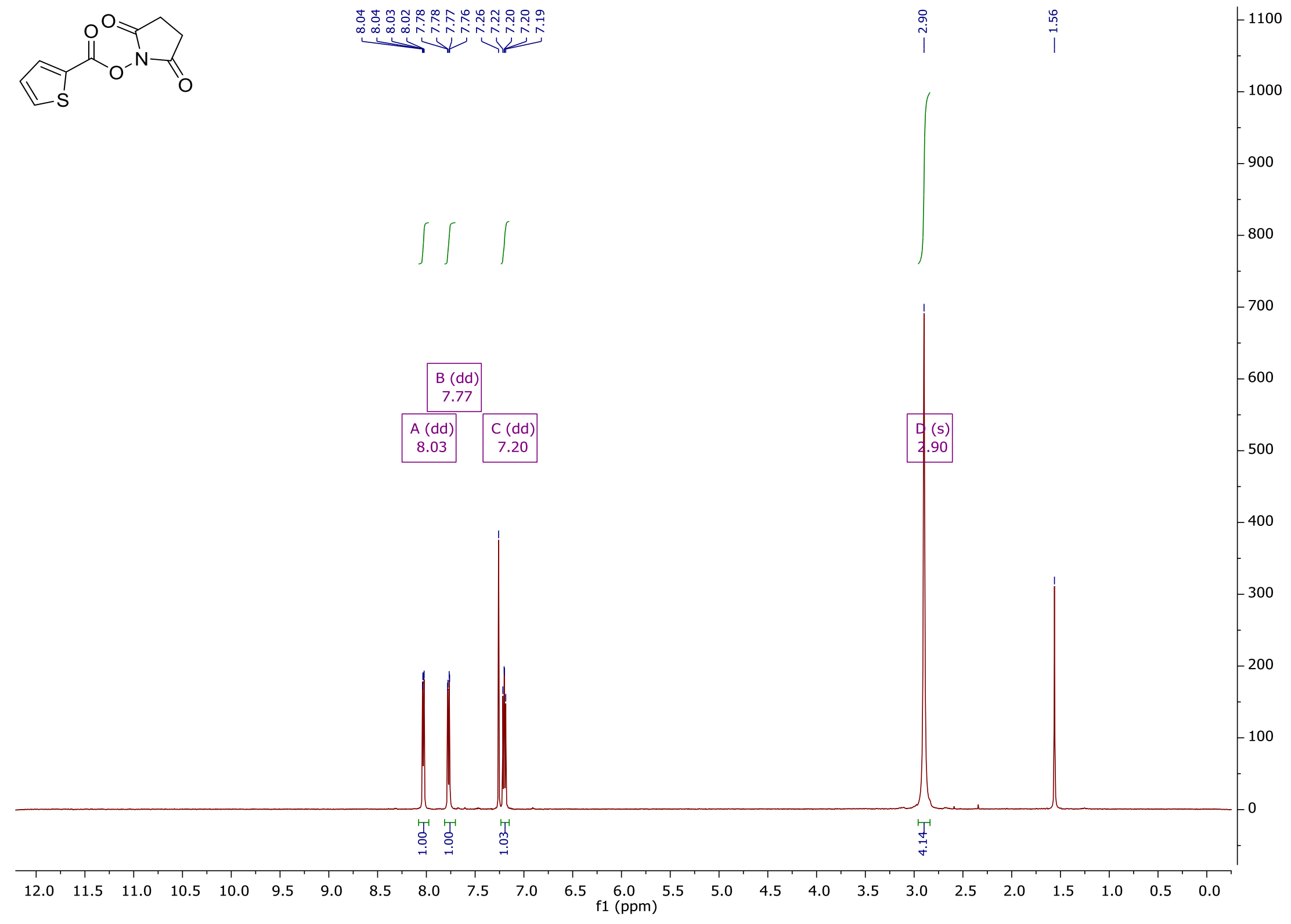


S5 $\left({ }^{13} \mathrm{C}\right.$ NMR in $\left.\mathrm{CDCl}_{3}\right)(75 \mathrm{MHz})$

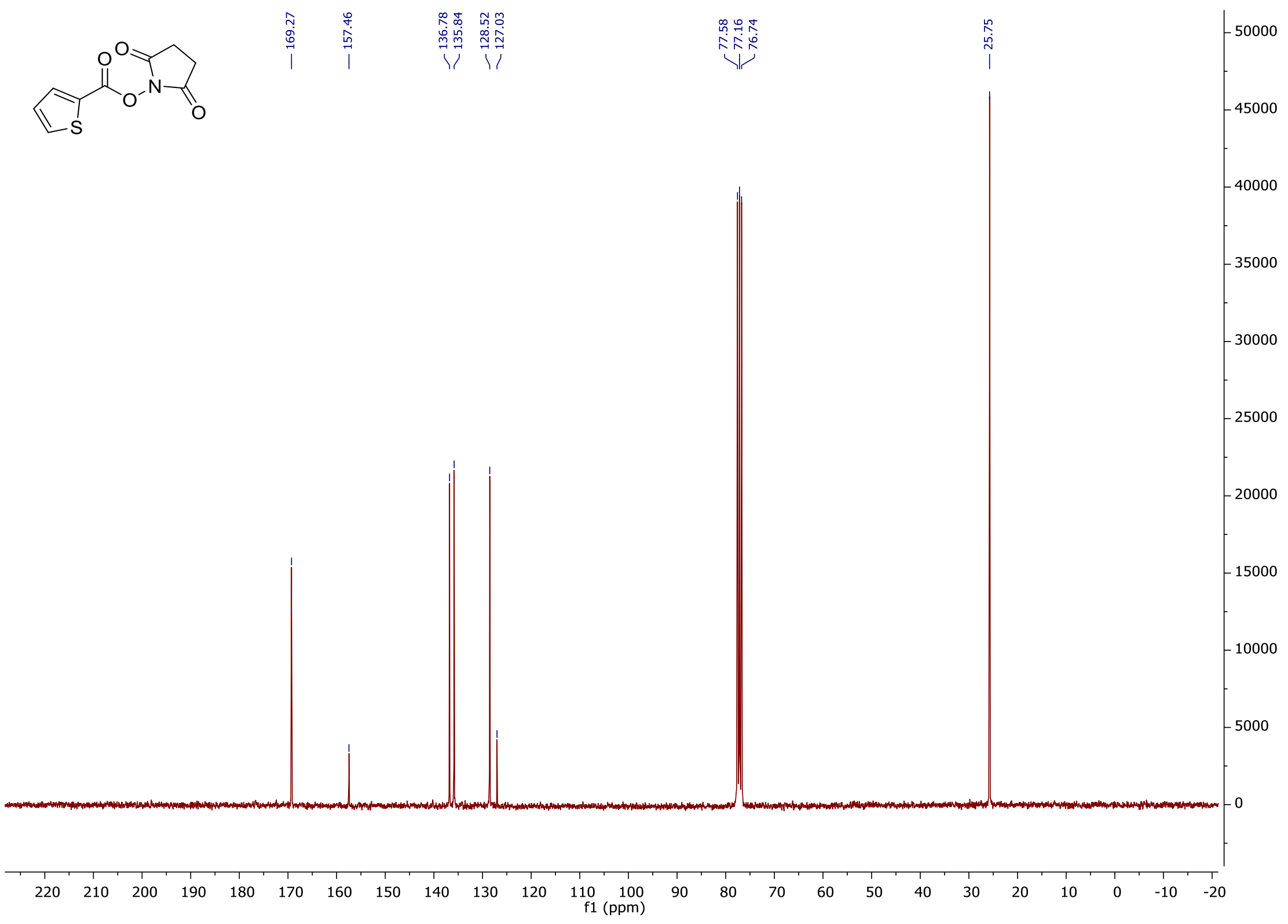


S6 $\left({ }^{1} \mathrm{H}\right.$ NMR in $\left.\mathrm{CDCl}_{3}\right)(300 \mathrm{MHz})$

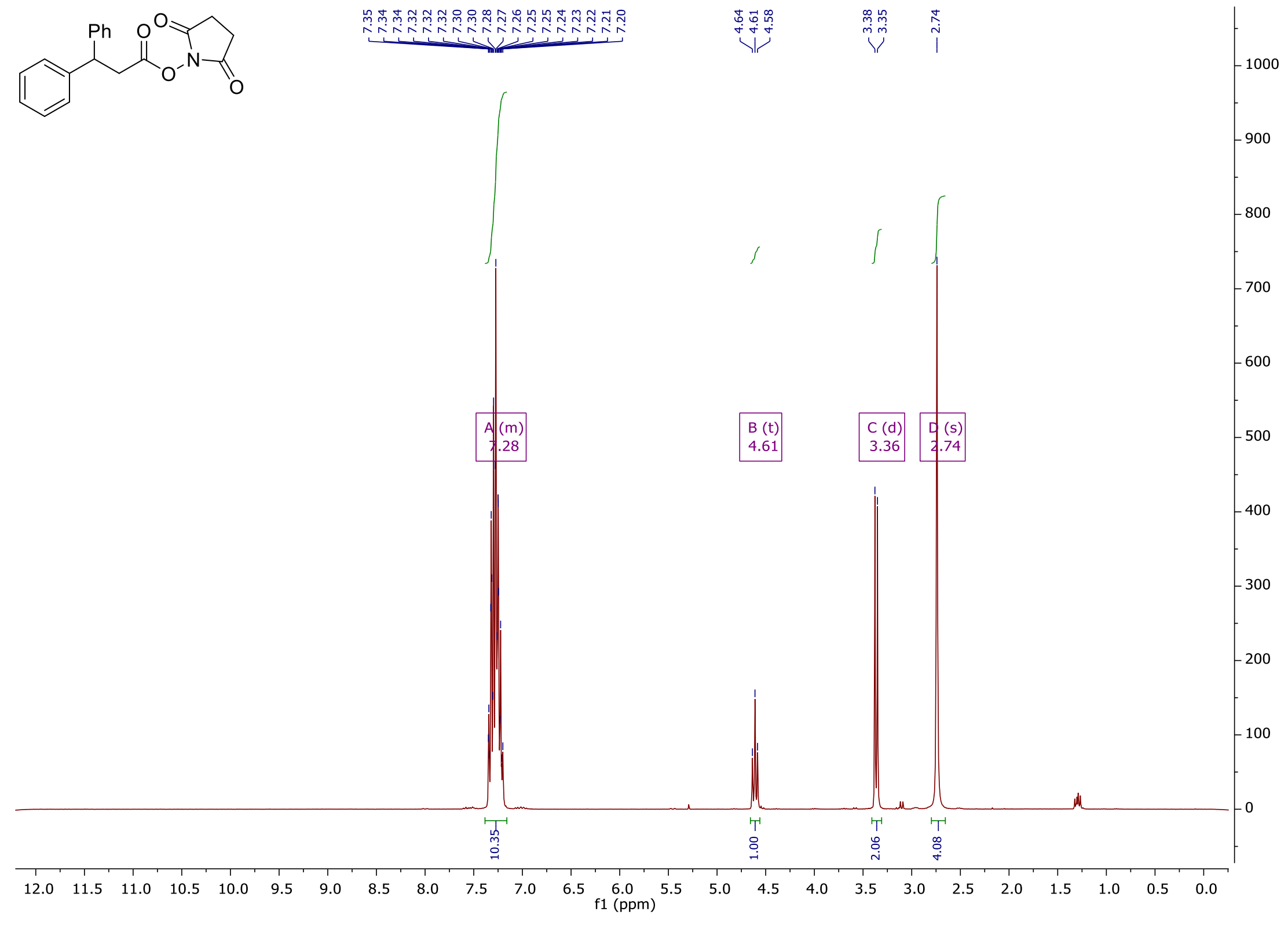




\section{S6 $\left({ }^{13} \mathrm{C}\right.$ NMR in $\left.\mathrm{CDCl}_{3}\right)(75 \mathrm{MHz})$}

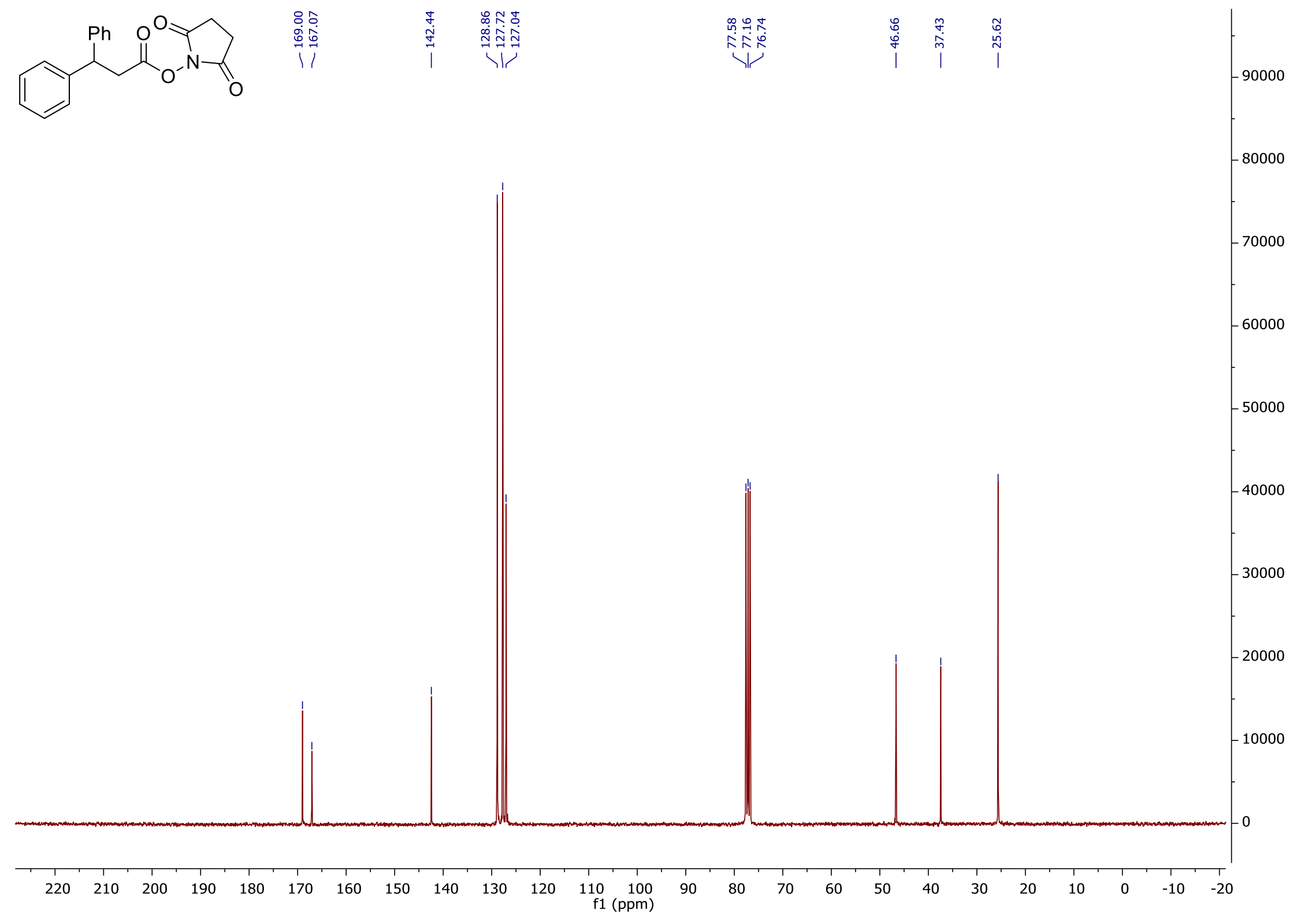


S7 ( ${ }^{1} \mathrm{H}$ NMR in $\left.\mathrm{CDCl}_{3}\right)(300 \mathrm{MHz})$

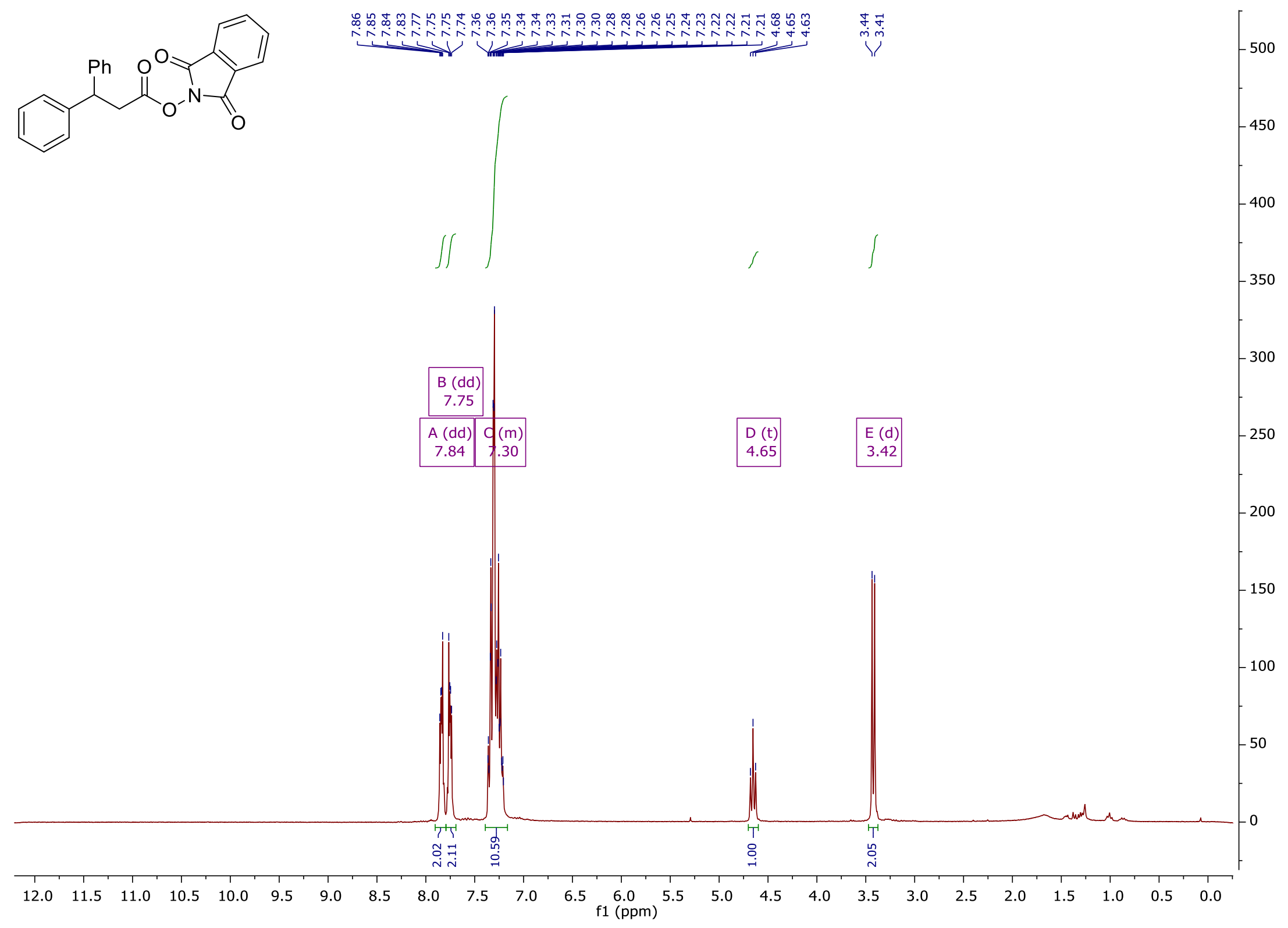


S7 $\left({ }^{13} \mathrm{C}\right.$ NMR in $\left.\mathrm{CDCl}_{3}\right)(75 \mathrm{MHz})$

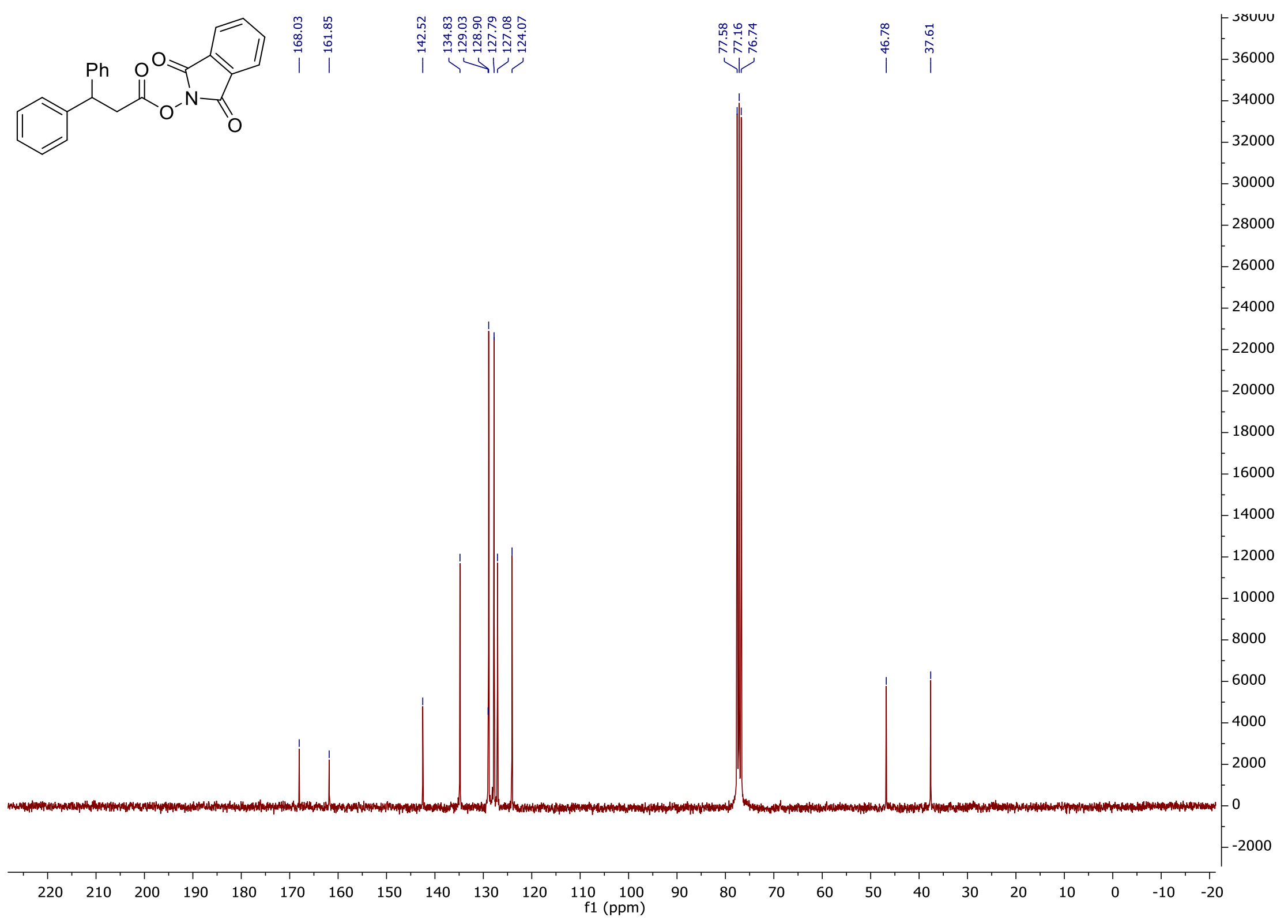


S8 ( ${ }^{1} \mathrm{H}$ NMR in $\left.\mathrm{CDCl}_{3}\right)(300 \mathrm{MHz})$

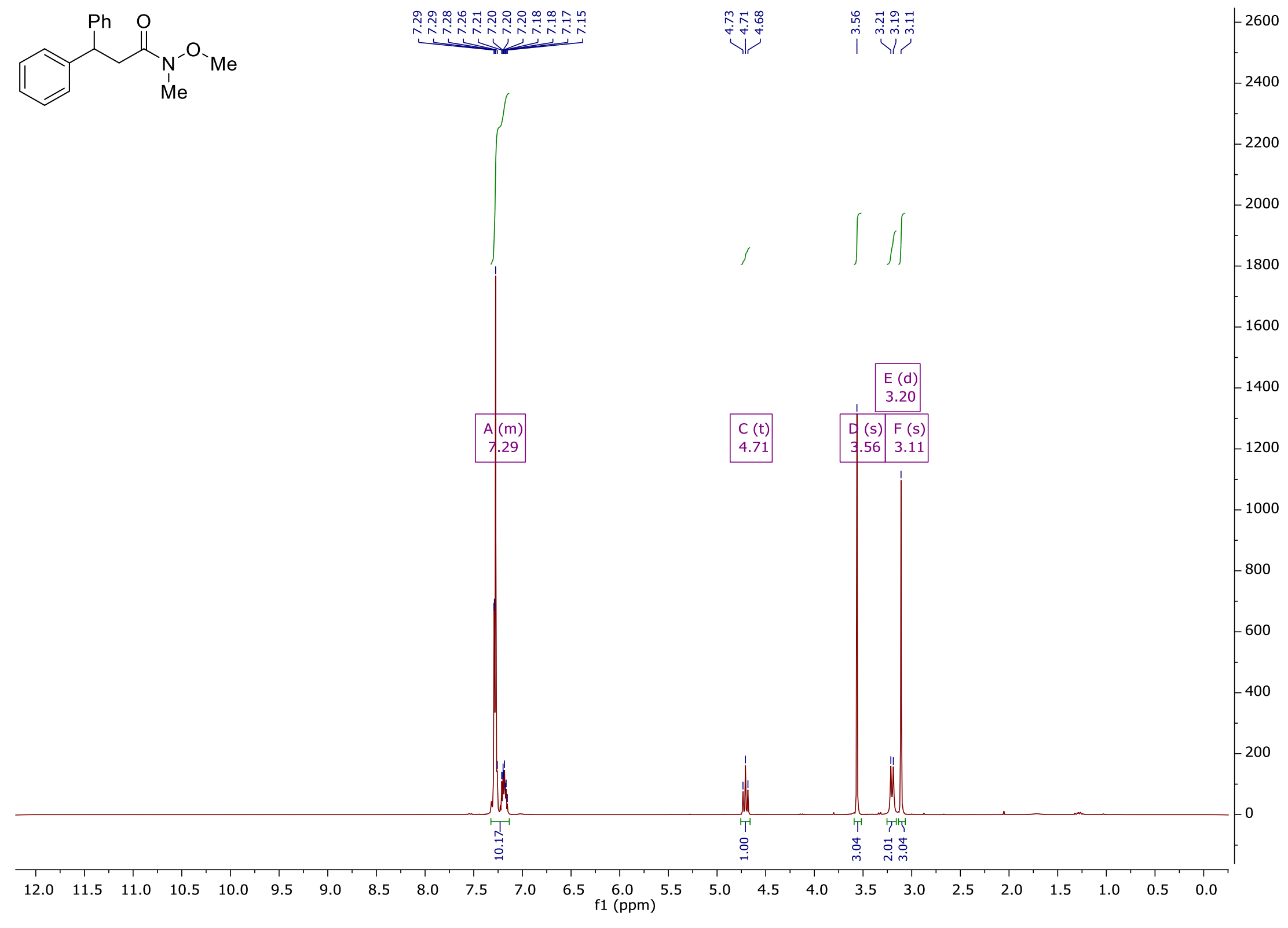




\section{S8 $\left({ }^{13} \mathrm{C} \mathrm{NMR}\right.$ in $\left.\mathrm{CDCl}_{3}\right)(75 \mathrm{MHz})$}

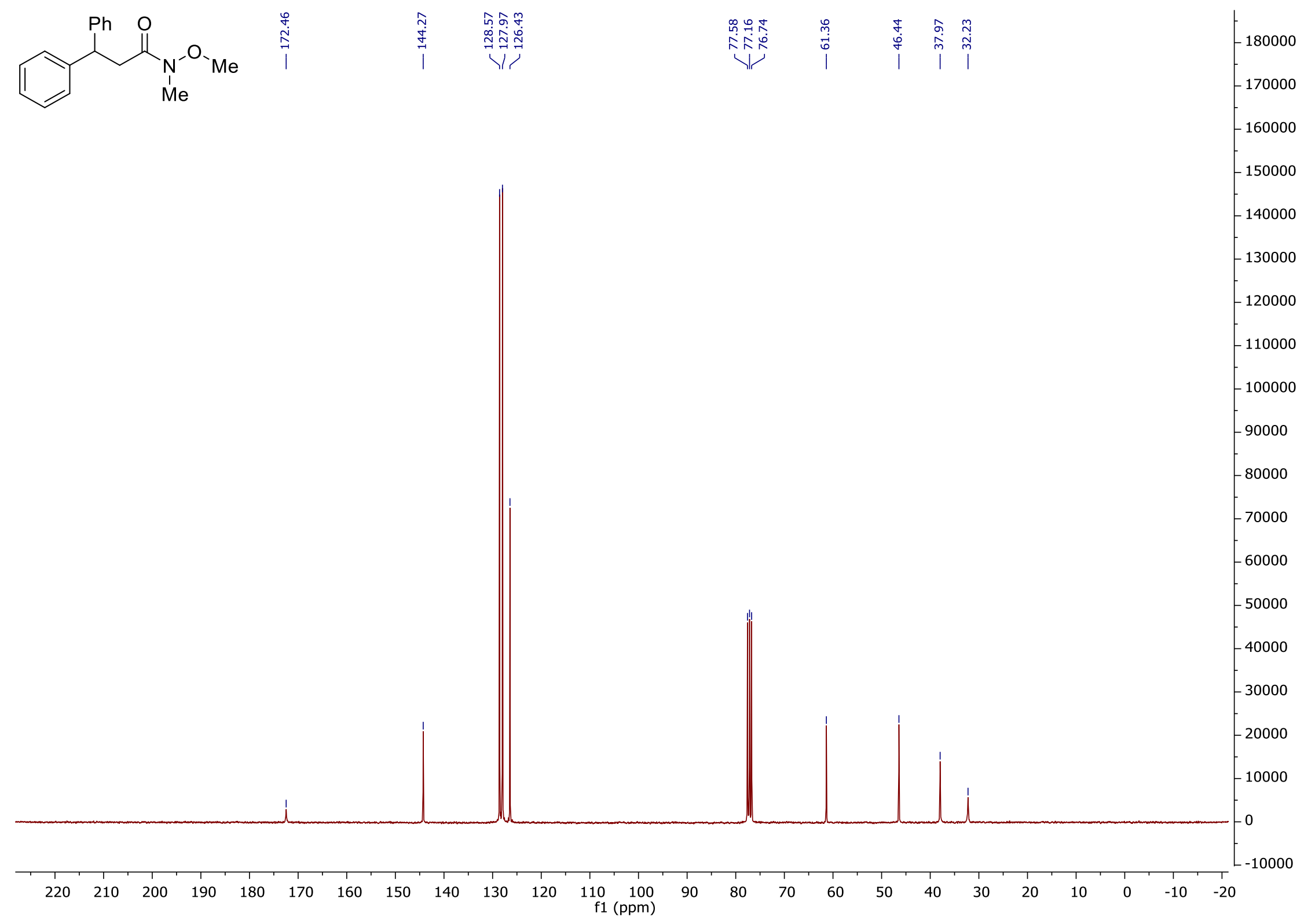


S9 ( $\left({ }^{1} \mathrm{H}\right.$ NMR in $\left.\mathrm{CDCl}_{3}\right)(300 \mathrm{MHz})$

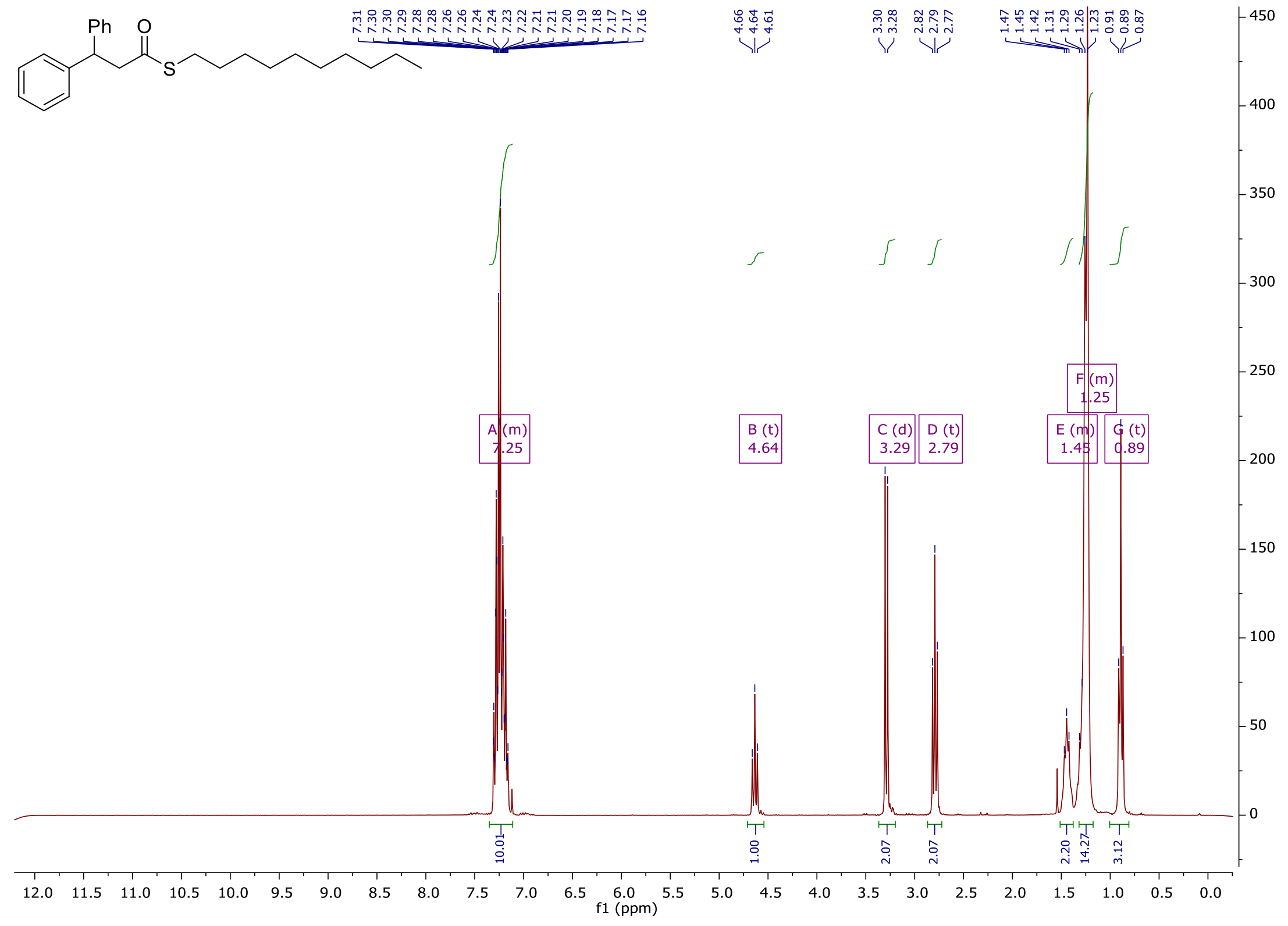


S9 $\left({ }^{13} \mathrm{C} \mathrm{NMR}\right.$ in $\left.\mathrm{CDCl}_{3}\right)(75 \mathrm{MHz})$

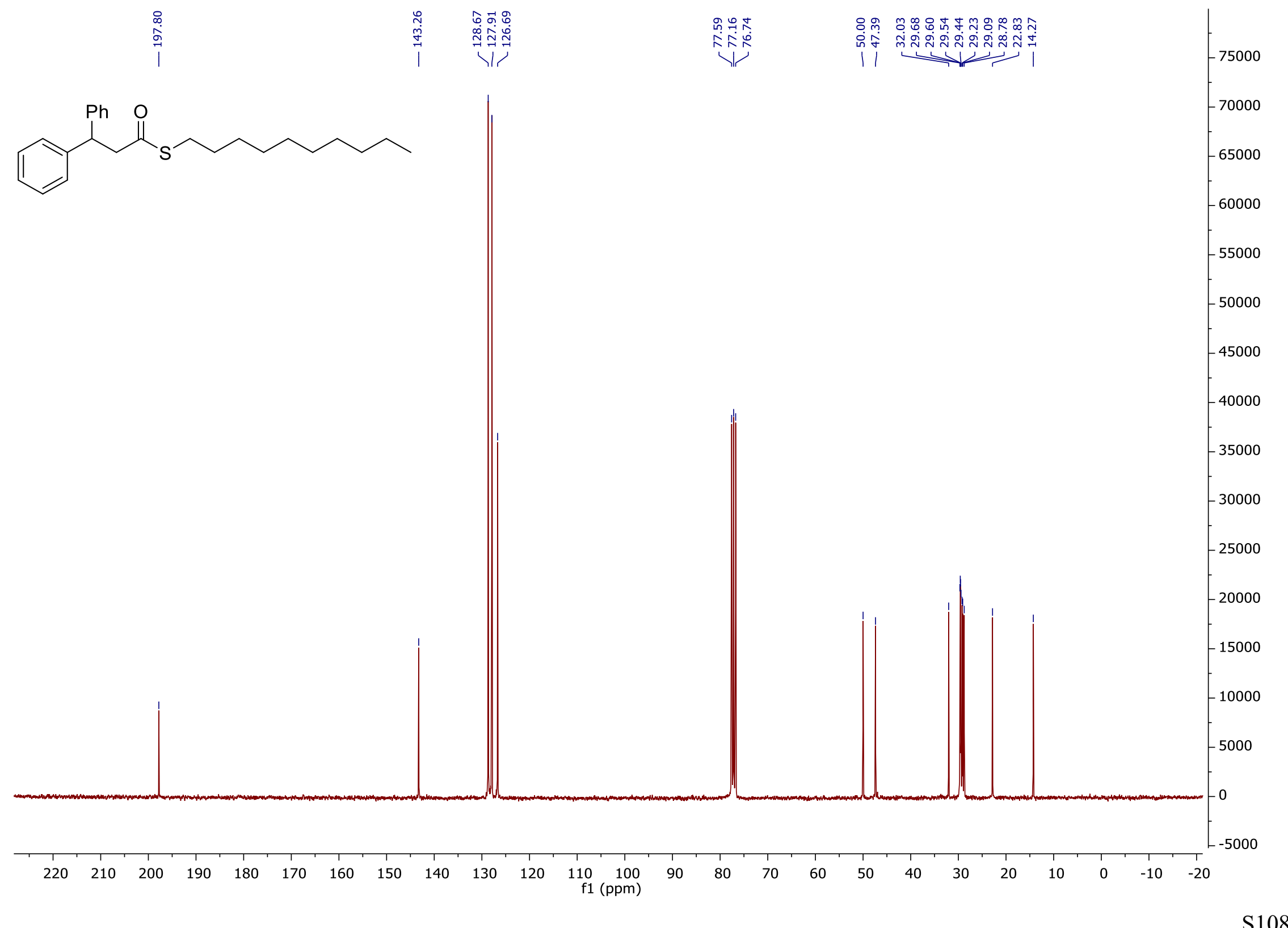

